\title{
Free-Flow Variability on the Jess and Souza Ranches, Altamont Pass
}

\author{
R. Nierenberg \\ Altamont Energy Corporation \\ San Rafael, California
}

March 1989

SERI Technical Monitor: W. Bollmeier

Prepared under DOE/SERI Cooperative Agreement No. DE-FC023-86CH10253

Solar Energy Research Institute

A Division of Midwest Research Institute

1617 Cole Boulevard

Golden, Colorado 80401-3393

Prepared for the

U.S. Department of Energy

Contract No. DE-AC02-83CH10093 


\section{NOTICE}

This report was prepared as an account of work sponsored by an agency of the United States government. Neither the United States government nor any agency thereof, nor any of their employees, makes any warranty, express or implied, or assumes any legal liability or responsibility for the accuracy, completeness, or usefulness of any information, apparatus, product, or process disclosed, or represents that its use would not infringe privately owned rights. Reference herein to any specific commercial product, process, or service by trade name, trademark, manufacturer, or otherwise does not necessarily constitute or imply its endorsement. recommendation, or favoring by the United States government or any agency thereof. The views and opinions of authors expressed herein do not necessarily state or reflect those of the United States government or any agency thereot.

Printed in the United States of America

Available from:

National Technical Information Service

U.S. Department of Commerce

5285 Port Royal Road

Springtield, VA 22161

Price: Microfiche A01

Printed Copy A07

Codes are used for pricing all publications. The code is determined by the number of pages in the publication. Information pertaining to the pricing codes can be found in the current issue of the following publications which are generally available in most libraries: Energy Research Abstracts (ERA); Government Reports Announcements and Index (GRA and I); Scientific and Technical Abstract Reports (STAR); and publication NTIS-PR-360 available from NTIS at the above address. 


\section{PREFACE}

The following report is the sixth in a series of such documents that present the findings of field tests conducted under the Department of Energy's (DOE) Cooperative Field Test Program with the U.S. wind industry. This report provides the results of a study to collect data at two windfarms. The two wind turbine arrays, located in the Altamont Pass east of San Francisco, were instrumented with anemometers and a central monitoring computer. To obtain a high spatial density of wind-speed measurements, every other turbine in both arrays was instrumented. Wind-speed data were collected over a period of four days during the summer high-wind season with all turbines shut down. The resultant data set was analyzed to determine the spatial variability of the wind resource in the two arrays. Because no turbine wakes were present, variation in the flow was caused by the interaction of the flow with the terrain and was not a function of turbine wake interaction.

The free-flow data sets can be used by other researchers to refine numerical free-flow computer models. The data sets will be used to fine tune and validate these computer models. In addition, the free-flow data will be compared to results of a wake energy deficit study also under way on these turbine arrays.

The success of this project is due to a number of people, who the author wishes to acknowledge. Gary Wayne and Tom Morton of Altamont Energy Corporation conceived the idea. Morton, along with Brian Smith of Grant Line Energy Corporation (now KENETECH Service Company) managed the entire project. Richard Farrell and Kevin $O^{\prime}$ Keefe of Altamont Energy Corporation assisted in arranging private-sector funding. Dave Kresse, of KENETECH Service Company, helped supervise the installation and operation of the data collection network. Philip Frame, a consulting meteorologist, provided wind forecasts and synoptic weather discussions and assisted with network installation and data processing. Walter Sass, Ken Cohn, and Mike Sacarny, of Second Wind, Inc., designed and built the central monitoring computer, communications hardware, and software, which operated flawlessly. Dennis Elliott, of Pacific Northwest Laboratory (PNL), and Alan Miller, formerly with PNL, assisted in the project planning, subsequent execution, and review. Warren Bollmeier of the Solar Energy Research Institute (SERI) and Steve Sargent of DOE assisted in the management of this project. Special thanks go to Howden Wind Parks Inc., for making their acoustic doppler measurements of the inversion on the Souza Ranch available. 


\section{SUMMARY}

The objective of the free-flow study was to collect a sufficient wind data base to describe the general spring/summer (high-wind season) wind flow over the Jess and Souza Ranch areas. To do this, a central monitoring computer was installed on each ranch. The computers were connected by communication cables to 50 turbines on the Souza Ranch and 150 turbines on the Jess Ranch. Anemometers were installed on every other turbine on 12-ft booms 35 ft above ground level (AGL). Spacing. between anemometers was approximately 200 ft in the crosswind direction by $450 \mathrm{ft}$ in the parallel direction. A total of 23 turbines on the Souza Ranch were instrumented this way, as were two multilevel meteorological towers. On the Jess Ranch, 77 turbines were instrumented, about half at $35 \mathrm{ft}$ AGL and half at $50 \mathrm{ft}$ AGL, and four additional towers were also instrumented.

Wind data were collected for approximately a 100-hour period on each ranch. All turbines were shut down during these periods so that no turbine wakes would be present. The data periods were selected by the meteorologist to insure that they occurred during typical spring/summer flow regimes.

There were several reasons for collecting this free-flow data:

- The data were to be analyzed to determine the flow variability over the study area. The high density of sensors, which was nearly unprecedented in previous publicly funded micrositing studies, allowed a microscale examination of the spatial flow variability. Large variations in energy production had been observed previously within these turbine arrays and at other similar arrays. The free-flow data set allowed a determination of how much of this variability was caused by differences in ambient flow conditions, without turbine wakes.

- The two ranches had different levels of terrain complexity; this would allow a comparison of terrain influences on the two ranches.

- The variations in available energy would be compared to subsequent wake energy-deficit measurements to be made on the same ranches.

- The data set would be useful to other researchers, especially those interested in computer modeling of flow over complex terrain.

The raw data collected by the central computer consisted of 10-minute averages. These 10-minute averages were processed into hourly averages. The hourly averages were screened to ensure the quality of the data. When that process was completed, the data from all turbine anemometers were correlated to a designated upwind reference anemometer. Correlation coefficients and speed ratios were calculated between the turbines and the reference site. The ratios were then plotted on topographic maps, and isopleths were drawn around areas of equal speed ratios. By observation, patterns in the flow were quite apparent.

On the Souza Ranch, speed ratios to the reference tower ranged from $77 \%$ to $110 \%$, for a range of $33 \%$. On the Jess Ranch, ratios ranged from $60 \%$ to $100 \%$, for a range of $40 \%$. On both ranches, flow variations over very small areas were present. For example, within a distance of $400 \mathrm{ft}$, changes of $20 \%$ in speed and $35 \%$ in theoretical energy were measured. 
Elevation enhances flow, as expected. However, upstream terrain features appear to play the most significant role in flow variability in these study areas. Several valleys oriented parallel to the predominant flow appear to channel the flow to a great extent. Turbine anemometers downwind of the valleys had enhanced wind speeds relative to other turbines away from the outflow from these valleys. Small hills approximately $150 \mathrm{ft}$ higher than the surrounding terrain had the opposite effects of the valleys. Turbines located up to $1500 \mathrm{ft}$ downwind of these hills had lower speed ratios than did surrounding turbines. Correlation coefficients at these sites were also affected by these hills. The coefficients were generally lowest at these sites. However, the correlation coefficients improved dramatically as the height of the low-level subsidence inversion increased. The speed ratios at these sites also improved as the inversion height increased. Terrain features upwind of the site appear to play as significant a role in the flow variability as do terrain features within the site. 


\section{TABLE OF CONTENTS}

Page

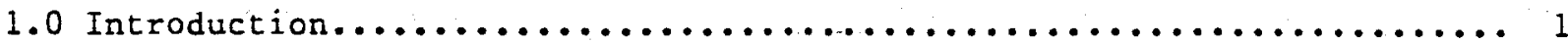

1.1 Meteorological Discussion of the Altamont Pass................

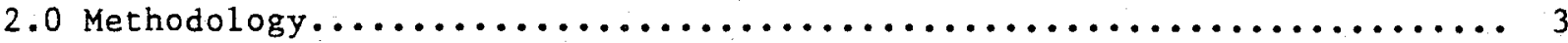

2.1 Study Areas......................................

2.2 Monitoring Equipment.............................

2.2 .1 Anemometry ................................. 3

2.2.2 Central Monitoring Computer and Communicating

Turbine Monitors (CTMs) ......................... 8

2.3 Data Processing....................................10

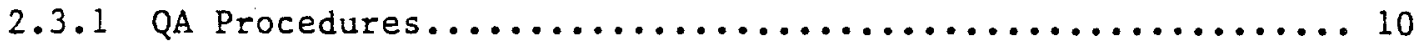

2.3 .2 Site J-08 Sensor Problems........................11

3.0 Data Analysis.....................................13

3.1 Data Sets...................................... 13

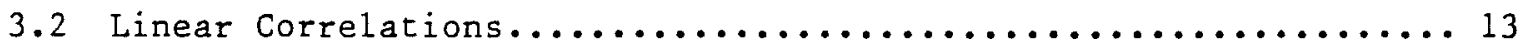

3.2 .1 Souza Ranch................................13

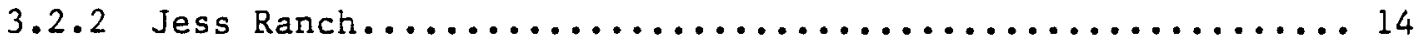

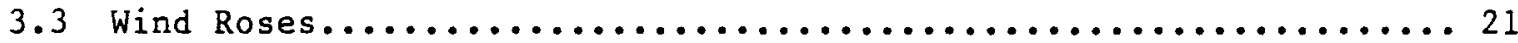

3.4 Diurnal Mean Speeds................................... 22

3.5 Vertical Shear..................................... 23

3.6 Wind-Speed Frequency Distribution and Theoretical Energy....... 23

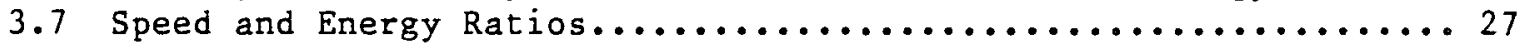

3.7 .1 Souza Ranch Ratios............................. 27

3.7 .2 Jess Ranch Ratios............................. 33

4.0 Conclusions.......................................43

Appendix A: Synoptic Meteorological Summaries for the Souza and Jess

Free-Flow Studies................................... 44

A.1 Summaries for the Souza Study, September 10-14, 1987.... 44

A.2 Summaries for the Jess Study, October $1-3$ and

October 7-10,1987............................46

Appendix B: Anemometer Calibrations.............................90

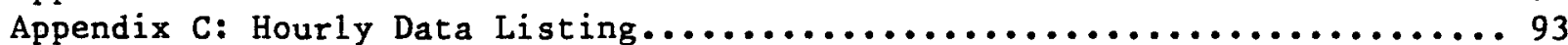

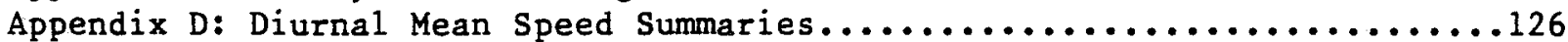




\section{LIST OF FIGURES}

Page

2-1 Jess Ranch and Surrounding Terrain....................... 4

2-2 Souza Ranch and Surrounding Terrain...................... 5

$2-3$ Jess Ranch.........................................

$2-4 \quad$ Souza Ranch..........................................

3-1 Hourly Correlation Coefficient ( $r$ ) to $s-13,70-f t$ Level.......... 15

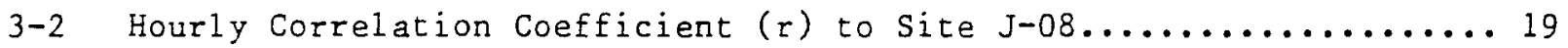

3-3 Hourly Correlation Coefficient (r) to Site J-04................20

3-4 Speed Ratios (\%) to Reference Site s-13, 70-ft, for Al1 Hours...... 29

3-5 Theoretical Energy Ratios (\%) to Reference Site S-13, 70-ft Level, for All Hours Based on Nordtank 65 Power Curve, No Shear Adjustments................................... 30

3-6 Speed Ratios (\%) to Reference Site S-13, 70-ft Level, for

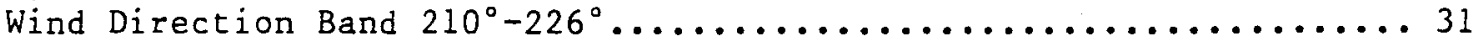

3-7 Speed Ratios (\%) to Reference Site S-13, 70-ft Level, for

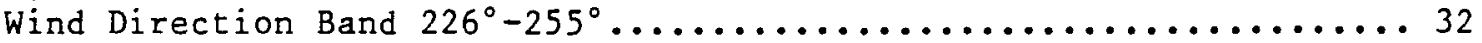

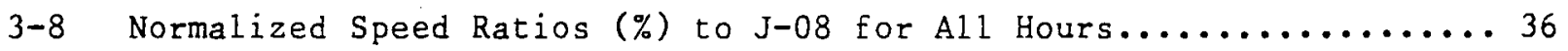

3-9 Theoretical Energy Ratios (\%) to J-08, Nordtank 65 Curve,

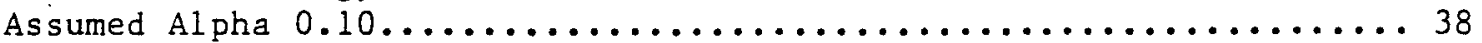

3-10 Normalized Speed Ratios (\%) to J-08 for Wind Direction

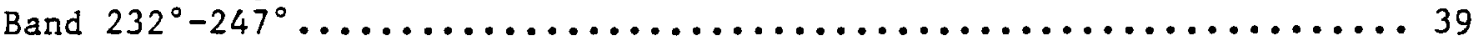

3-11 Normalized Speed Ratios (\%) to J-08 for Wind Direction

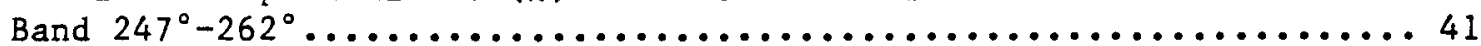

3-12 Normalized Speed Ratios (\%) to J-08 for October 1-3............. 42

A-1 Surface Weather Map for September 10, 1600 PST................ 50

A-2 500-mb Map for September 10, 1600 pst..................... 51

A-3 Surface Weather Map for September 11, 0400 PST................ 52

A-4 500-mb Map for September 11, 0400 PST..................... 53

A-5 Surface Weather Map for September 11, 1600 PST................ 54

A-6 500-mb Map for september 11,1600 PST PST.................. 55 


\section{LIST OF FIGURES (Continued)}

$\underline{\text { Page }}$

A-7 Surface Weather Map for September 12, 0400 PST............. 56

A-8 500-mb Map for September 12, 0400 PST.................. 57

A-9 Surface Weather Map for September 12,1500 PST............. 58

A-10 500-mb Map for September 12, 1600 PST................... 59

A-11 Surface Weather Map for September 13, 0400 PST............. 60

A-12 500-mb Map for September 13, 0400 PST................... 61

A-13 Surface Weather Map for September 13, 1600 PST.............. 62

A-14 500-mb Map for September 13, 1600 PST.................. 63

A-15 Surface Weather Map for September 14,0400 PST.............. 64

A-16 500-mb Map for September 14, 0400 PST................... 65

A-17 Surface Weather Map for September 14,1600 PST..............66

A-18 500-mb Map for September 14, 1600 PST.................... 67

A-19 Surface Weather Map for October 1,1600 PST................ 68

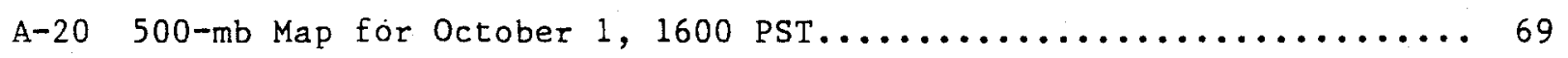

A-21 Surface Weather Map for October 2,0400 PST.................70

A-22 500-mb Map for October 2, 0400 pST..................... 71

A-23 Surface Weather Map for October 2,1600 PST............... 72

A-24 500-mb Map for October 2,1600 PST..................... 73

A-25 Surface Weather Map for October 3,0400 PST............... 74

A-26 500-mb Map for October 3, 0400 PST...................... 75

A-27 Surface Weather Map for October 7,0400 PST............... 76

A-28 500-mb Map for October 7,0400 pST................... 77

A-29 Surface Weather Map for October 7,1600 pst............... 78

A-30 500-mb Map for October 7,1600 PST........................ 79

A-31 Surface Weather Map for October 8,0400 PST............... 80 


\section{LIST OF RIGURES (Concluded)}

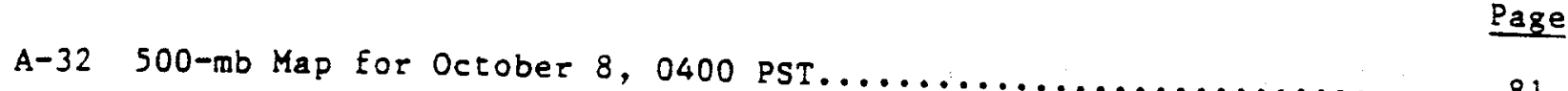

A-33 Surface Weather Map for October 8,1600 PST................ 82

A-34 500-mb Map for October 8,1600 PST ................... 83

A-35 Surface Weather Map for October 9,0400 PST................ 84

A-36 $500-m b$ Map for October 9,0400 PST $\ldots \ldots \ldots \ldots \ldots \ldots \ldots \ldots \ldots \ldots \ldots$

A-37 Surface Weather Map for October 9,1600 PST................ 86

A-38 500-mb Map for October 9,1600 PST .................... 87

A-39 Surface Weather Map for October 10,0400 PST.............. 88

A-40 500-mb Map for October 10,0400 PST .................... 89 


\section{LIST OF TABLES}

$2-1$ Jess Ranch Meteorological Towers.........................

2-2 Souza Ranch Meteorological Towers....................... 8

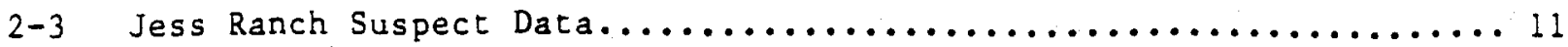

3-1 Souza Hourly Correlation Coefficients ( $r$ ) to s-13 at $70 \mathrm{ft} \ldots \ldots \ldots . .14$

3-2 Jess Ranch Hourly Correlation Coefficient ( $r$ ) to Reference Anemomerers and Adjacent Sites......................... 17

3-3 s-13 wind Rose Joint Frequency Distribution................. 21

3-4 J-08 wind Rose Joint Frequency Distribution............... 22

3-5 Diurnal Mean Wind Speeds............................ 22

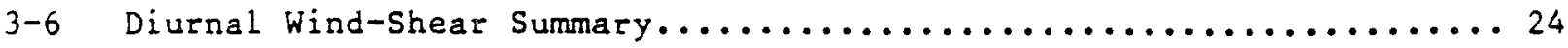

3-7 Wind speed Frequency Distribution for site $s-13 \ldots \ldots \ldots \ldots \ldots \ldots \ldots$

3-8 Wind Speed Frequency Distribution for Site J-08............. 26

3-9 Souza Ranch Ratios to Site s-13, 70-ft Reference Anemometer........ 28

3-10 Jess Ranch Free-Flow Data Analysis...................... 34

B-1 Table of Calibrated Anemometers........................... 91 


\subsection{INTRODUCTION}

Approximately 7000 wind turbines, ranging in size from $20 \mathrm{~kW}$ to $750 \mathrm{~kW}$, have been installed in the Altamont Pass during the 1980s. Few wind developers had the opportunity to conduct detailed micrositing studies. Many felt it was adequate to make wind measurements at one to five sites per square mile. Thus, wind turbine developers and operators have been amazed at the enormous variability in energy production within the pass, both between turbine arrays and, especially, within the arrays. The enormous variations could be caused by (1) individual turbine operating characteristics, (2) free-flow variability from terrain, or ( 3 ) wake effects. This free-flow study was conducted to explain turbine production variability and, in particular, to address the free-flow variability. A second study was also conducted simultaneously to address the wake effects.

\subsection{Meteorological Discussion of the Altamont Pass}

A brief discussion about the driving mechanism of the winds in the Altamont Pass is appropriate. The Altamont Pass is located in a gap in the California coastal range, approximately 45 miles east of San Francisco. To the east of the pass 1 ies the great Central Valley, and to the west lies several ranges of coastal hills, the San Francisco Bay, and the Pacific Ocean. During the spring and summer months, the high-wind season, there is a large temperature gradient between the cool Pacific Ocean and the hot interior valleys. The coastal waters near San Francisco remain in the high $50 \mathrm{~s}\left(15^{\circ} \mathrm{C}\right)$, whereas the Central Valley temperatures rise to nearly $100^{\circ}\left(35^{\circ} \mathrm{C}\right)$. As the interior temperatures rise, air density decreases and the hot, low-density air rises. This creates a low-pressure area over the interior, known as a thermal trough. The thermal trough can usually be found in the summer months, extending from the Coachella Valley in southeastern California up through the Central Valley (Sacramento - San Joaquin). Over the eastern Pacific Ocean, which is cool by comparison, the Pacific high-pressure cell is nearly always present. Thus, there is a pressure difference or gradient between the coast and the inland valleys. The result of this pressure difference is wind that blows from areas of high pressure to low pressure.

A second important meteorological feature is the subsidence inversion. An inversion occurs when a layer of warm air is found over a layer of cool air. Associated with the Pacific high-pressure cell is the west-coast subsidence inversion, the culprit blamed for trapping California smog. This inversion is present along the California coast and over the eastern Pacific during most of the spring and summer months. The mean summer height of the inversion base, measured at the Oakland airport (about 35 miles west of the pass) is $1350 \mathrm{ft}$ above mean sea level (MSL). Measurements of the inversion height in the pass itself show it to be several hundred feet AGL, which is slightly lower than it is in Oakland.

The significance of the inversion is that it acts as a lid. Air flowing inland from high pressure to low pressure is accelerated through coastal gaps like the Altamont Pass. The presence of the inversion enhances the venturi effect of the pass by providing an additional constriction to the flow, from the top. Thus, air flow is squeezed from the bottom and sides by the pass itself, and from the top by the inversion. In addition, the inversion can enhance the blocking capability of obstacles such as hills. If the inversion 
is strong and fairly close to the ground, the wind is forced to flow around hills rather than over them.

The inland pressure gradient and the inversion are the basic elements responsible for the persistent spring/summer winds in the Altamont Pass. As mentioned earlier, the height of the inversion in the pass is only several hundred feet AGL. Wind speeds are higher below the inversion, and decrease with height above the inversion. At times, the inversion is very close to the ground and vertical wind shear is negative (i.e., wind speeds decrease with height).

The free-flow data were collected during typical spring/summer conditions. A detailed synoptic discussion of the meteorological conditions during the free-flow periods can be found in Appendix $A$. 


\subsection{STUDY METHODOLOGY}

The methodology for the free-flow study was to collect several days of 10-minute-average wind data from the anemometer arrays. The data were collected during typical spring/summer (high-wind) season flow regimes. All turbines were shut down during the data collection periods.

The 10-minute data were processed to hourly averages and analyzed on a mainframe computer. The analysis consisted of calculating correlation coefficients and speed ratios between a designated reference site and all other sites. The values were then manually plotted, and isopleths were drawn.

\subsection{Study Areas}

The Jess Ranch study area is in the eastern portion of the Altamont Pass. The ranch is on relatively flat terrain, by Altamont Pass standards, with elevation dropping gently to, the northeast. Although the study area is relatively flat, the terrain immediately upwind is quite complex. There are two hills just west of the Jess Ranch that are several hundred feet higher than the ranch. Elevations in the study area range from $600 \mathrm{ft}$ MSL in the southwest corner to $400 \mathrm{ft}$ MSL in the northeast corner. The study area is approximately one-half square mile, one mile long (in the north-south direction) and onehalf mile wide. The northern half of the ranch has Nordtank turbines, and the southern half has ESI turbines. Figure 2-1 is a topographic map of the Jess Ranch and surrounding terrain.

The Souza Ranch study area is in the northern portion of the Altamont Pass, about six miles north-northwest of the Jess Ranch. The terrain in the Souza study area is more complex than that in the Jess study area. The study area is on gently rolling hills. Immediately south of the study area is a canyon trending east-west, with an elevation of about $350 \mathrm{ft}$ MSL. Elevations in the study area range from $440 \mathrm{ft}$ MSL in the western portion to $300 \mathrm{ft}$ MSL in the eastern portion. The Souza study area is about half the size of the Jess area. All turbines in the Souza Ranch study area are Nordtanks. Figure 2-2 is a topographic map of the Souza area and surrounding terrain.

\subsection{Monitoring Equipment}

\subsubsection{Anemometry}

Due to the relatively flat terrain on the Jess Ranch, the turbines are laid out in straight rows, normal to the west-southwest flow. Spacing between turbines, within rows, is $100 \mathrm{ft}$ ( 2 rotor diameters); spacing between rows is about $450 \mathrm{ft}$ ( 9 rotor diameters). Anemometers were installed on every other turbine, so the spacing between sensors is $200 \mathrm{ft}$ crosswind by $450 \mathrm{ft}$ downwind. Figure 2-3 is a topographic map of the Jess Ranch and shows the locations of the turbines and anemometer towers. The large letters indicate the locations of groups of turbines. Individual turbines are plotted as small triangles, and only the end turbines in a given row are labeled. For example, see the upper left corner of Figure 2-3, in the row adjacent to the J-08 anemometer. Here, there are six turbines, but only Ll and L6 are labeled.

A total of 77 anemometers were installed on the Jess Ranch on booms on every other turbine. Again, the southern half of the Jess Ranch consists of ESI-54S 


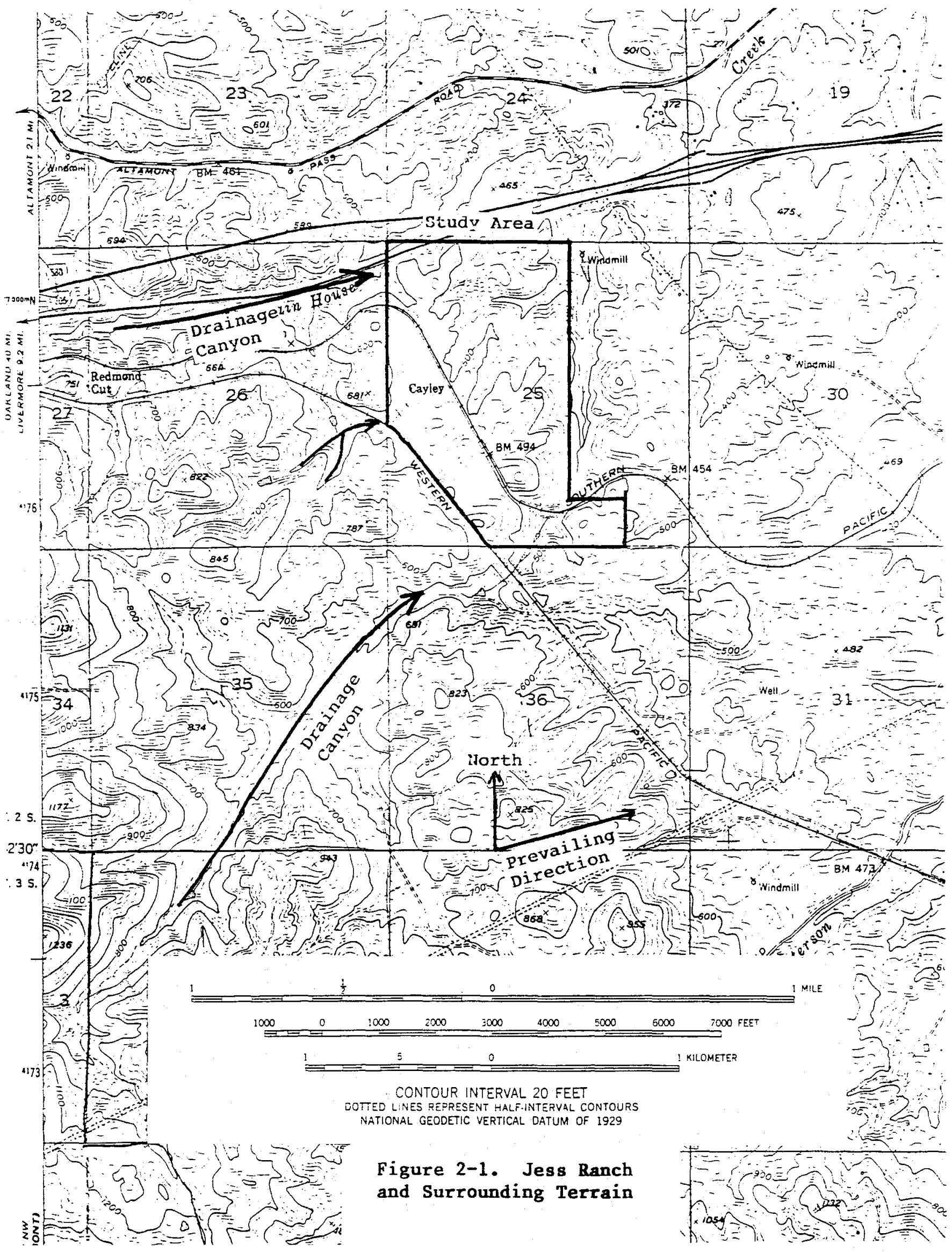




\section{SEPI}

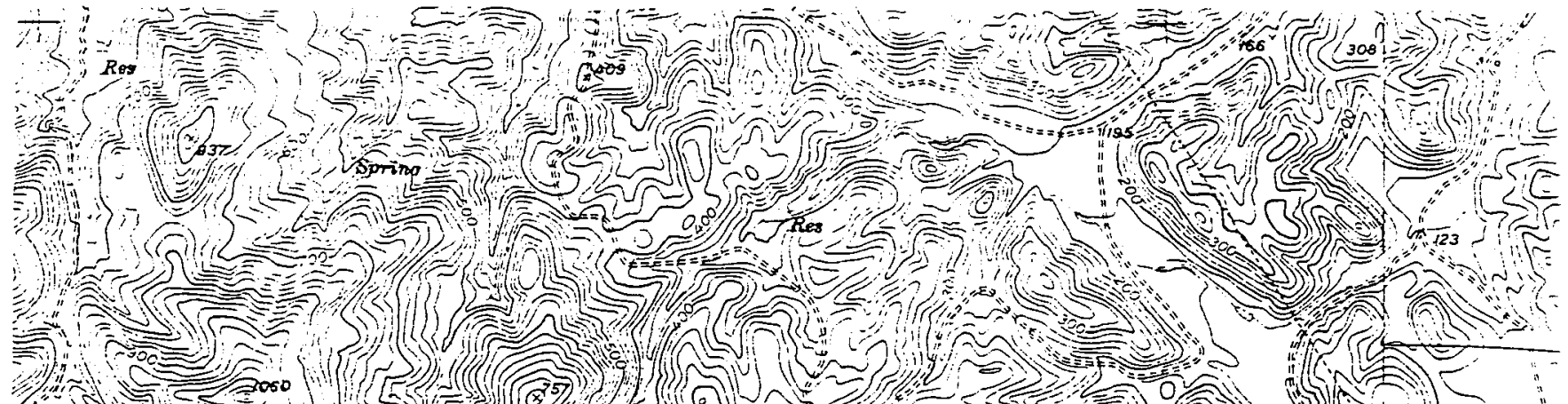

$\Rightarrow$ तson $=$ 急 $=\approx$ spring

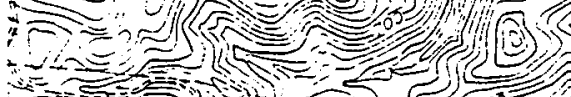

$\mathrm{A}$

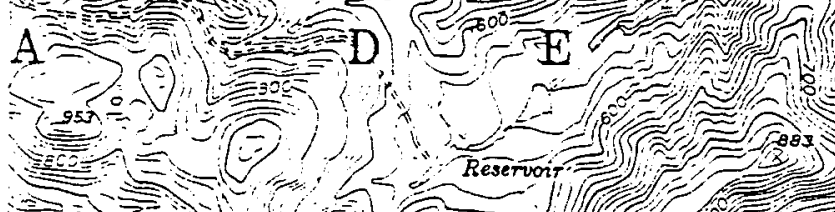

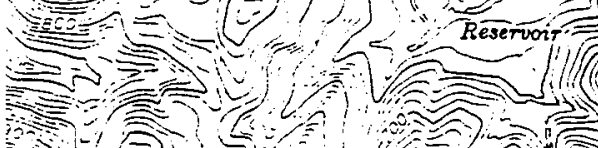

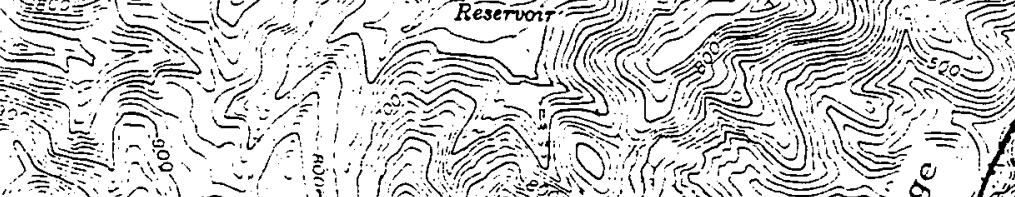

(

(196

(1)

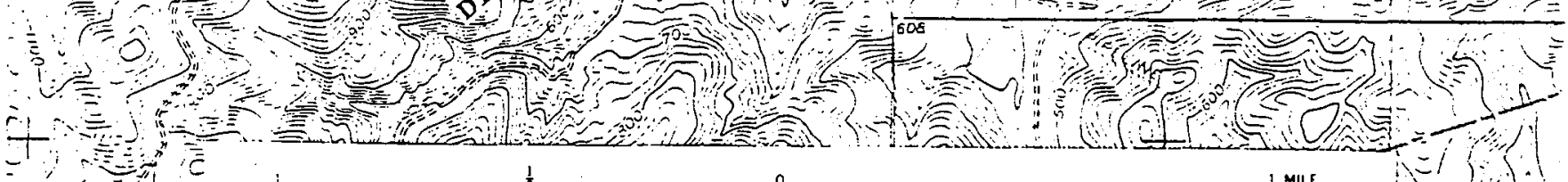
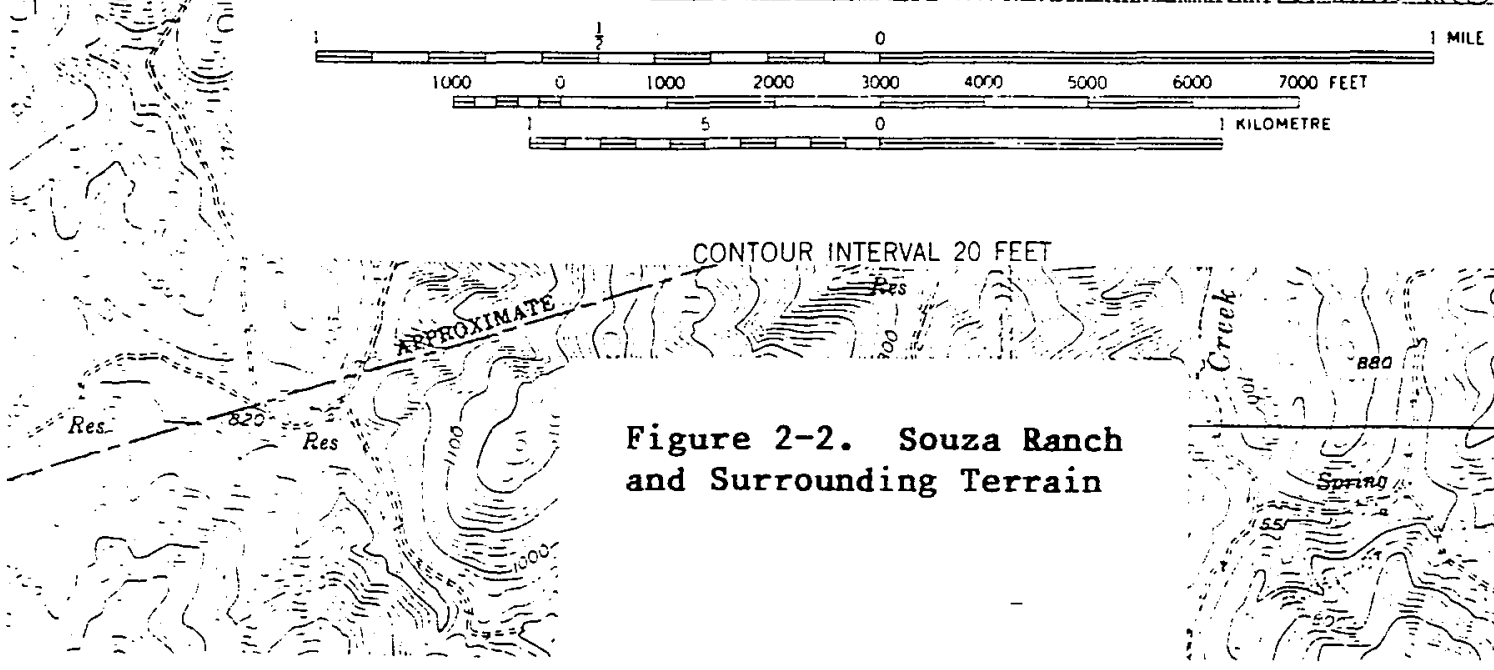

CONTOUR INTERVAL 20 FEET
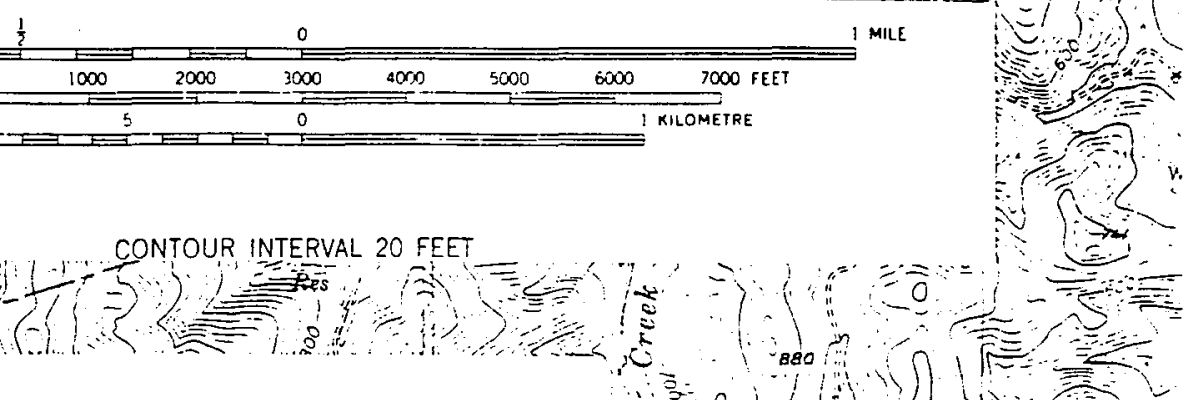

Figure 2-2. Souza Ranch and Surrounding Terrain

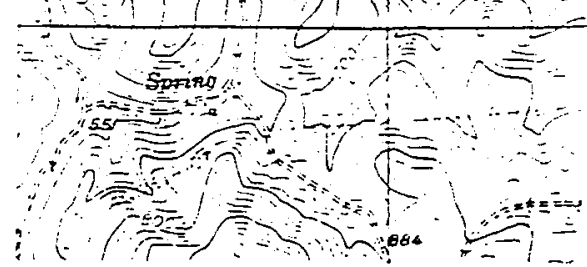




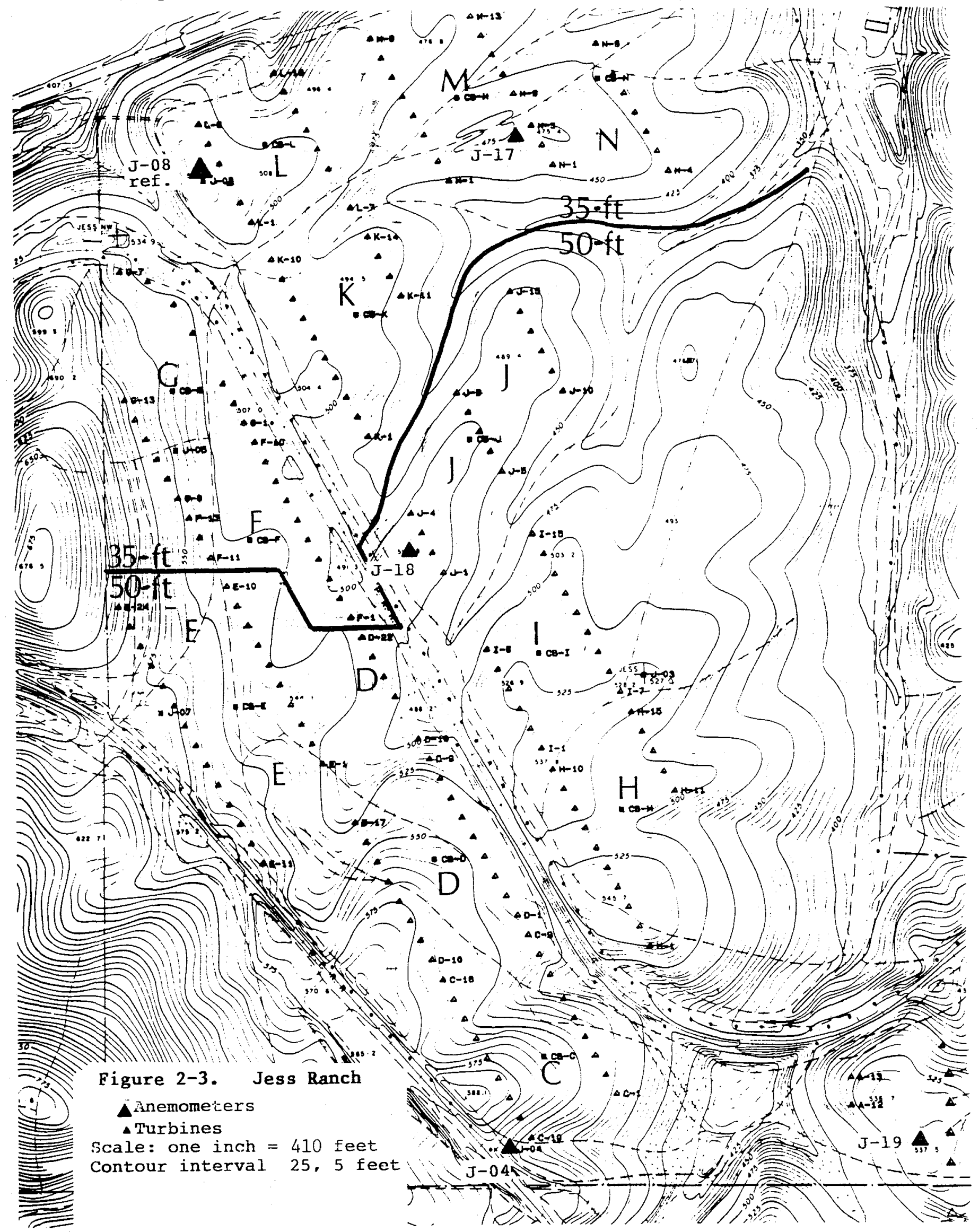


turbines on 80-ft towers. On Figure 2-3, these are in the $C, D, E, H, I$, and $\mathrm{J}$ groups. The northern half of the ranch consists of Nordtank $65-\mathrm{kW}$ turbines on 72-ft towers. These are in groups $F, G, K, L, M$, and $N$. Anemometers were installed on the ESI-54S turbines on existing $5-\mathrm{ft}$ booms at $50 \mathrm{ft}$ AGL. Anemometers were installed on the Nordtank turbines on $12-\mathrm{ft}$ booms at $35 \mathrm{ft}$ AGL. A longer boom was used on the Nordtanks because of their large tubular tower (versus the open-lattice ESI tower). The anemometers were installed at the 35-ft (versus 50-ft) level to keep them below the rotor. The boom orientation was north-northwest, which is normal to the flow, so there was no tower shadow. On the Nordtank turbines, $35 \mathrm{ft}$ AGL is about $11 \mathrm{ft}$ below the bottom of the rotor; on the ESI turbines, $50 \mathrm{ft}$ AGL is $3 \mathrm{ft}$ below the rotor. Of course, the rotors were stationary during the free-flow data collection period, so no interference was expected.

In addition to the 77 anemometers installed on turbines, there were five additional meteorological towers. Table 2-1 1ists the towers, their locations, measurement levels, and sensor types. Note that two of the Jess Ranch towers were not integrated with the central monitoring computer (to be discussed hereafter), and data collected at these towers were hourly averages, not 10-minute averages.

Table 2-1. Jess Ranch Meteorological Towers

\begin{tabular}{|c|c|c|c|c|}
\hline Tower & Location & $\begin{array}{l}\text { Sensor } \\
\text { Height ( } f t)\end{array}$ & $\begin{array}{l}\text { Sensor } \\
\text { Type }\end{array}$ & Status \\
\hline$J-08$ & $\begin{array}{l}\text { Upwind of } \\
\text { turbine L4 }\end{array}$ & 50 & $\begin{array}{l}\text { R.M. Young } \\
\text { propvane }\end{array}$ & $\begin{array}{l}\text { Reference tower, } \\
\text { integrated with } \\
\text { central monitoring } \\
\text { computer. }\end{array}$ \\
\hline $\mathrm{J}-17$ & $\begin{array}{l}\text { Upwind of } \\
\text { turbine N3 }\end{array}$ & 35,70 & Maximum cup & $\begin{array}{l}\text { Integrated with } \\
\text { central monitoring } \\
\text { computer. }\end{array}$ \\
\hline$J-18$ & $\begin{array}{l}\text { Upwind of } \\
\text { turbine } \mathrm{J} 3\end{array}$ & 35,70 & Maximum cup & $\begin{array}{l}\text { Integrated with } \\
\text { central monitoring } \\
\text { computer. }\end{array}$ \\
\hline$J-04$ & $\begin{array}{l}\text { Adjacent to } \\
\text { turbine C10 }\end{array}$ & 120 & Maximum cup & $\begin{array}{l}\text { Not integrated } \\
\text { with central }\end{array}$ \\
\hline & & 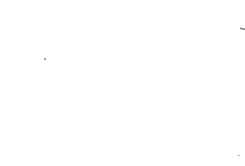 & - & $\begin{array}{l}\text { computer. } \\
\text { Separate data } \\
\text { logger records } \\
\text { hourly averages. }\end{array}$ \\
\hline $\mathrm{J}-19$ & Near $A-12$ & 40,80 & Maximum cup & $\begin{array}{l}\text { Not integrated with } \\
\text { central computer. } \\
\text { Separate data } \\
\text { logger records } \\
\text { hourly averages. }\end{array}$ \\
\hline
\end{tabular}

The Souza Ranch terrain is slightly more complex than that of the Jess study area, and the turbine rows follow the local ridge lines to some extent. The 
turbine rows are not as straight, nor are they all parallel. Spacing between anemometers and sensor height is the same as on the Jess Ranch. However, the boom orientation is northwesterly because the prevailing wind direction is southwesterly. Figure 2-4 is a topographic map showing the location of turbine anemometers and towers. Anemometers were installed on 23 Souza turbines as well as 3 meteorological towers. Table 2-2 1ists the characteristics of these towers. All three towers were connected to the central monitoring computer.

Table 2-2. Souza Ranch Meteorological Towers

\begin{tabular}{|c|c|c|c|c|}
\hline Tower & Location & $\begin{array}{c}\text { Sensor } \\
\text { Height ( } f t)\end{array}$ & $\begin{array}{l}\text { Sensor } \\
\text { Type }\end{array}$ & Status \\
\hline$s-13$ & $\begin{array}{l}\text { Upwind of } \\
\text { turbine } G 5\end{array}$ & 35,70 & $\begin{aligned} 35^{\prime}= & \text { Maximum cup } \\
70^{\prime}= & \text { R.M. Young } \\
& \text { Propvane }\end{aligned}$ & $\begin{array}{l}\text { reference } \\
\text { tower }\end{array}$ \\
\hline$s-27$ & $\begin{array}{l}\text { Adjacent to } \\
\text { turbine E7 }\end{array}$ & 45,80 & Maximum cup & \\
\hline$S-29$ & $\begin{array}{l}\text { Upwind of } \\
\text { turbine } 09\end{array}$ & 50 & Maximum cup & \\
\hline
\end{tabular}

Except for those on the two reference towers, all sensors were Maximum type 40 cups. The sensors are molded-lexan 3-cup anemometers. The transducer is an alternating current (AC) generator that produces a sine wave signal. The signal frequency is proportional to wind speed. The manufacturer specifies the accuracy to be $+2.5 \%$ of actual speed and the distance constant to be $9.7 \mathrm{ft}$.

The two reference towers, J-08 on Jess and S-13 on Souza, had R.M. Young "Wind Monitor" Model $\$ 05103$ propvanes. Wind direction is measured with a potentiometer, and wind speed is measured with an AC sine wave generator. The manufacturer specifies the distance constant to be $8.9 \mathrm{ft}$ and the accuracy to be $+2.0 \%$ of actual speed.

Approximately 60 of the Maximum cups and both propvanes were tested in the University of California at Davis wind tunnel. The test procedure called for approximately 30 samples for each sensor in wind speeds ranging from 10 to $60 \mathrm{mph}$. Almost all of the cups tested read $1 \%-2 \%$ below tunnel speed, and the mean speed of all cups tested was $98.7 \%$ of tunnel speed. The two propvanes read about $1 \%$ above tunnel speed. Appendix $B$ 1ists the results of the wind tunnel tests and the location of sensors.

\subsubsection{Central Monitoring Computer and Communicating Turbine Monitors (CTMs)}

The Second Wind, Inc., monitoring system on each ranch has two main components: (1) the central computer and (2) the CTMs. Each individual turbine has a CTM that monitors turbine status, turbine power, and wind speed and direction (if wind sensors are installed). The CTMs operate on a one-second scan interval and calculate and store 10-minute averages. The CTMs are connected 


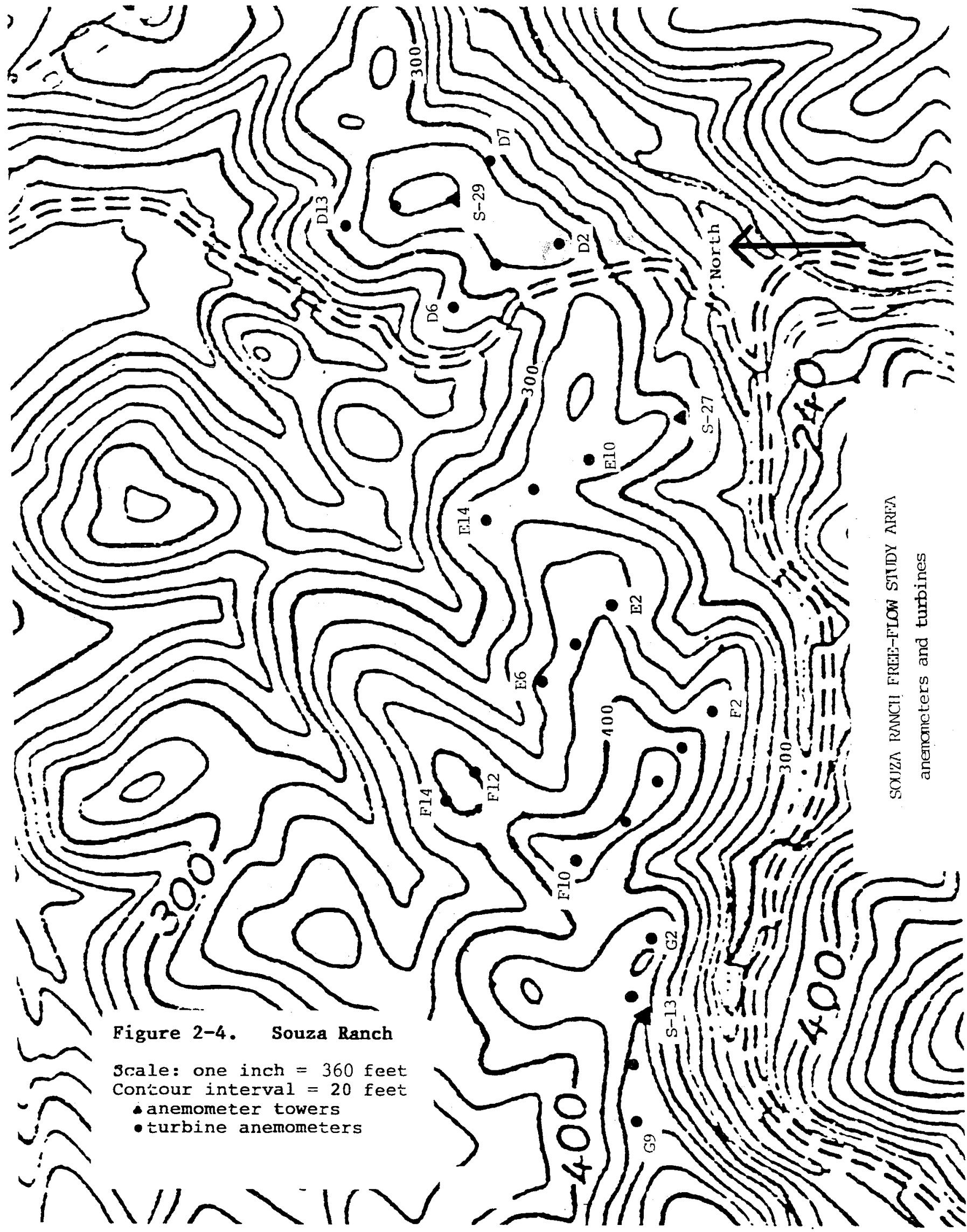


via cable to the central computer, which interrogates all turbines once a minute. The central computer performs many functions; of particular importance to this study is the data archiving function. The 10-minute data are stored on a Bernoulli disk drive, which permits these data to be accessed by other computers.

Because of the electrical noise in a wind-farm environment, the CTM has a threshold voltage for wind-speed signals. This threshold is equivalent to roughly $2 \mathrm{mph}$ for a Maximum cup and slightly higher for an R.M. Young propvane. A one-second scan below this 2-mph threshold would be interpreted as a 0 -mph reading. Thus, a 10 -minute average of $0 \mathrm{mph}$ could actually have been between 0 and $2 \mathrm{mph}$. Furthermore, during any 10-minute period below about $5 \mathrm{mph}$, there could be excursions below $2 \mathrm{mph}$ that would be read as zero. Thus, a true average wind speed of $5 \mathrm{mph}$ could be archived as a 4.5-mph average. As the average wind speed increases, there are fewer excursions below $2 \mathrm{mph}$, and this bias goes to zero. Almost all of the data collected were in winds well above $10 \mathrm{mph}$, so this problem is trivial. However, there are a few averages in the data set in the range of $0-5 \mathrm{mph}$ that are negatively biased.

\subsection{Data Processing}

The Second Wind, Inc., field computer stores the 10-minute averages. These data are transferred to the office computer on a Bernoulli disk. The office computer has two programs that were used to access these data. One program is a Data Dump facility that allows the user to specify a start and end time and a range of parameters. It creates a file that can be printed out for review of the 10-minute records. A second program is the hourly program that computes hourly averages from the six 10-minute records. The program creates an hourly average for any hour when three or more valid 10-minute records were available. The hourly program was used on all sites to generate hourly data. The hourly averages were transferred from the office computer to a PRIME mainframe computer for quality assurance (QA) and subsequent analysis.

\subsubsection{QA Procedures}

The hourly averages were loaded into a PRIME computer, where an extensive wind energy data base and software library resides. The QA procedures required calculating correlation coefficients and speed ratios, and also reviewing and plotting these. This was followed by scrutinizing any outlying data points that were revealed by these plots, and making some subjective judgment as to the data points' validity. Specifically, the following steps were taken:

1. Calculate correlation coefficients and speed ratios between the reference anemometer and all other sites on the ranch

2. Calculate correlation coefficients and speed ratios between all adjacent pairs of anemometers

3. Review the correlation coefficients and speed ratios, and investigate any sites that had peculiar speed ratios or correlations below 0.9

4. Scan both the hourly and 10-minute data listings to spot any suspect data points (an example of a suspect data point might be a 0 -mph wind speed at one level of a tower and a 20-mph wind speed at another level)

5. Delete any invalid data 
6. Recalculate correlation coefficients without invalid data and verify that a significant improvement in correlation was achieved

7. Fill in gaps where data were deleted using surrogate data from closest adjacent site (surrogate data points were created using linear regression equations).

Review of the Souza data set revealed no spurious data. All correlations were between 0.94 and 1.00 . A total of 2726 parameter-hours of data were collected, with a data recovery of $100 \%$.

Review of the Jess data set revealed suspect data at six sites. In most cases, the suspect data were for $0.0-\mathrm{mph}$ wind speeds when other levels or adjacent sites had strong winds. It has not been determined if the cause was a sensor, sensor wire, CTM, or communication failure. Table 2-3 lists suspect data sites.

Table 2-3. Jess Ranch Suspect Data

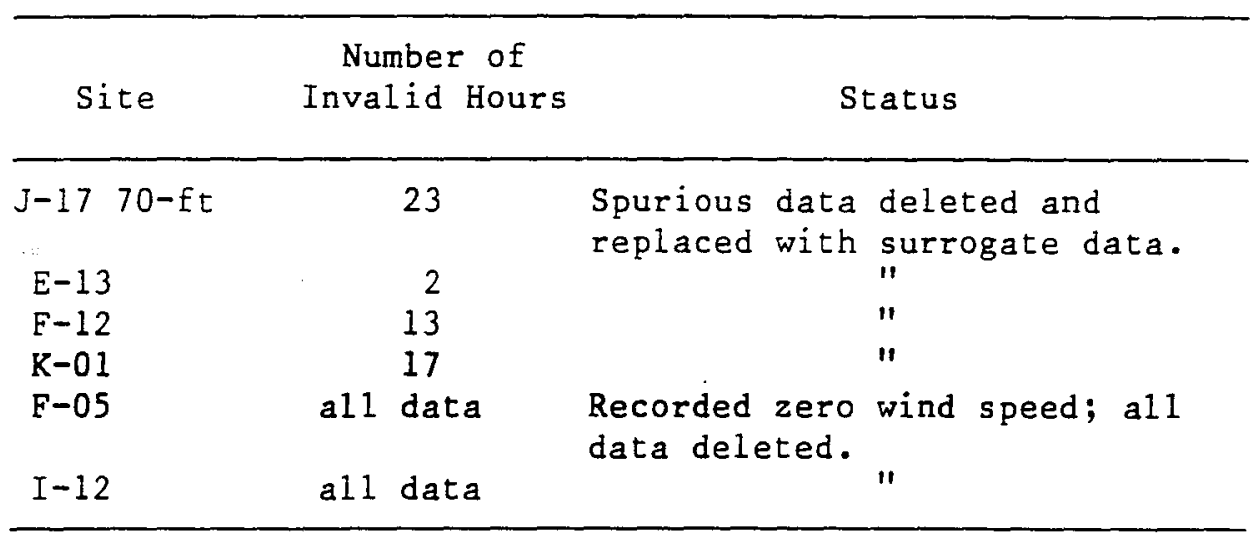

Thus, two sites, F5 and I12, were deleted altogether; an additional 55 hours of data from four turbines were also deleted. A total of 8717 parameter-hours of valid data were collected out of a possible 8976 parameter-hours, for a net data recovery of $97.1 \%$. The 55 hours of data were filled in at the four sites listed above; however, no attempt was made to fill in data from turbines F5 and 112 . Data recovery for the entire study, including both areas, was $97.8 \%$. This is an excellent rate of data recovery for a study of this scale.

\subsubsection{Site J-08 Sensor Problems}

Two problems were detected with the R.M. Young sensor at site J-08. This sensor was installed on September 7, 1987. Prior to this installation, three years of data had been collected at this site, as well as at site J-04. The established speed ratio between these sites for the previous three Septembers was $98.8 \%$ ( $\mathrm{J}-08$ was $98.8 \%$ of J-04). After installation of the R.M. Young sensor, this ratio jumped $2.8 \%$, to $101.6 \%$ of $\mathrm{J}-04$. It was felt that the $\mathrm{J}-08$ sensor might have a positive bias. To determine if this were true (in the field), a calibrated Maximum cup was installed at J-08 at the same level, in the field in January 1988. Three months of concurrent wind-speed data were collected by these two sensors. Correlation of all concurrent wind data, in 
winds of $10 \mathrm{mph}$ or greater, showed that the R.M. Young sensor was reading $2 \%$ higher than was the Maximum cup. The correlation was perfect. As a result, a11 wind speeds at J-08 were reduced by $2 \%$ to reflect this field calibration.

The other problem with site J-08 was in orientation of the vane. It was discovered that the north point on the wind vane was oriented toward $22.5^{\circ}$, or $22.5^{\circ}$ east of true north. With this orientation, all wind-direction data would be recorded $22.5^{\circ}$ too low. (For example, a true north wind at $360^{\circ}$ would read $337.5^{\circ}$.) It was evident from the base plate and guy wires that the mast had not turned but had been installed incorrectly. Therefore, $22.5^{\circ}$ have been added to J-08 wind-direction data.

These problems were not evident at the other R.M. Young sensor installed at site S-13 on the Souza Ranch. 


\subsection{DATA ANALYSIS}

\subsection{Data Sets}

Data collection took place on the Souza Ranch from September 10, 1987 at 1600 Pacific Daylight Time (PDT) through September 14, 1987 at 1400 PDT. The duration of the data collection phase was 94 hours, representing 564 10-minute samples. Data collection on the Jess Ranch took place in two periods: from October 1, 1987 at 1400 PDT through October 3, 1987 at 0500 PDT; and from October 7, 1987 at 0800 PDT through October 10, 1987 at 0900 PDT. During the first period on the Jess Ranch, light and variable winds occurred on October 2; these data were not included in the final data set. The duration of the Jess data collection phase was 102 hours, representing 612 10-minute samples. Although data collection took place in October on the Jess Ranch, the meteorological conditions were typical of summer, as shown in Appendix $A$. Appendix $A$ is a detailed synoptic discussion of the atmospheric conditions that occurred during the free-flow periods. A descriptive paragraph and two weather maps are included for every 12-hour period. The weather maps are a western U.S./eastern Pacific surface map and an "upper air" map of the 500-mb $(18,000-f t)$ level. This appendix will be of particular interest to meteorologists or readers with some knowledge of the subject.

A complete listing of the hourly data can be found in Appendix $C$, which lists up to 48 hours of data for 15 sites on each page. Data are listed synoptically (i.e., each line of data lists data for one hour for 15 sites).

\subsection{Linear Correlations}

Correlation is defined as the degree of relationship between variables. The correlation coefficient is a dimensionless number that varies from -1 to +1 . A positive correlation means that variable $y$ tends to increase as variable $x$ increases. A negative or inverse correlation means that variable y tends to decrease as variable $x$ increases. The correlation coefficient should not be confused with a ratio; two variables or sites could have a high degree of correlation, close to 1.0 , but have a ratio very different from unity. The square of the correlation coefficient is called the coefficient of determination. It is a useful term that is equal to the ratio of explained variation between two variables to the total variation.

Artificially high linear correlations can exist between two variables if both variables depend on time. Because many meteorological parameters are timedependent, the reader is cautioned that to some degree the high correlations discussed hereafter could be due to this phenomenon.

\subsubsection{Souza Ranch}

The first step in the data analysis was the correlation of all wind-speed data to the reference towers. Table 3-1 lists all the 1 inear correlation coefficients to reference site S-13. The sample size for all sites was 94 data points.

The table shows that all sites on Souza had correlation coefficients of 0.94 or better, which indicates excellent correlations. The mean correlation 
coefficient to site S-13 was 0.97 . The data on Table 3-1 are plotted on Figure 3-1.

Table 3-1. Souza Hourly Correlation Coefficients $(r)$ to $\mathrm{s}-13$ at $70 \mathrm{ft}$

\begin{tabular}{ll}
\multicolumn{2}{c}{ Site and } \\
Leve1
\end{tabular}

\subsubsection{Jess Ranch}

Table 3-2 1ists the correlation coefficients for the Jess Ranch. The correlations include the surrogate data points at the four sites listed in Table 2-3. The Jess sites were also correlated to the J-04, 120-ft tower. J-04 and J-08 are at opposite ends of the study area (see Figure 2-3). Table 3-2 1ists the correlation coefficients to these two sites. Sample size at all sites was 102 data points. In addition, the table lists the correlation of all sites to their adjacent site. The table shows that the mean correlation coefficient to adjacent sites was 0.98 , which is excellent. The mean correlation coefficient to Site J-08 was 0.89. This analysis on Jess was done as part of the QA process. Poor or fair correlations may be indicative of invalid data points. 


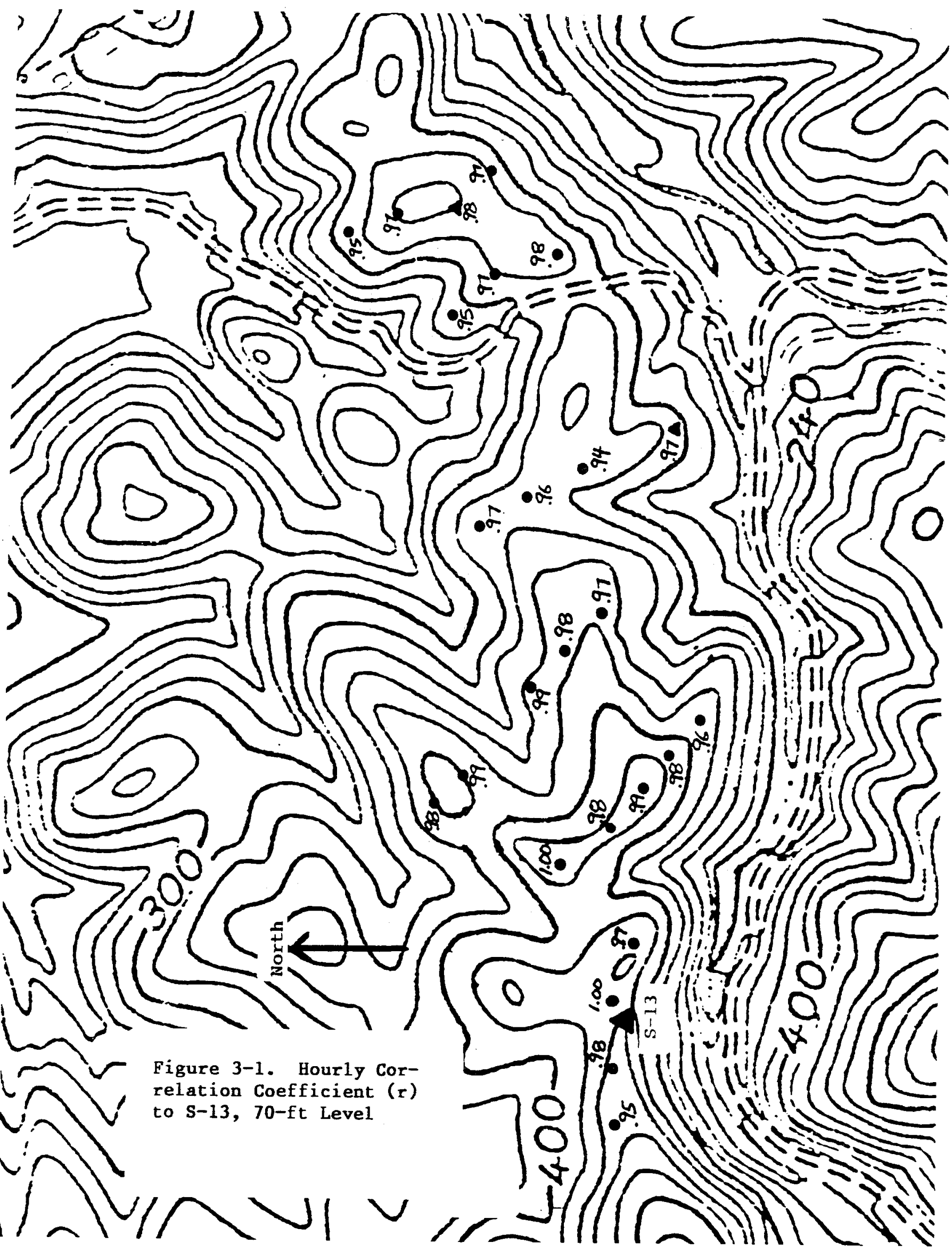


Table 3-2. Jess Ranch Hourly Correlation Coefficients to Reference Anemometers and Adjacent Sites

\begin{tabular}{|c|c|c|c|}
\hline $\begin{array}{l}\text { Location and } \\
\text { Level }\end{array}$ & $\mathrm{J}-08$ & $\mathrm{~J}-04$ & $\begin{array}{l}\text { d jacent } \\
\text { Site }\end{array}$ \\
\hline $\begin{array}{l}\text { Site J-08, } 50 \mathrm{ft} \text { (reference } \\
\text { Site J-04, } 120 \mathrm{ft} \\
\text { Site J-19, } 40 \mathrm{ft} \\
\text { Site J-17, } 35 \mathrm{ft} \\
\text { Site J-17, } 70 \mathrm{ft} \\
\text { Site J-18, } 35 \mathrm{ft} \\
\text { Site J-18, } 70 \mathrm{ft}\end{array}$ & $\begin{array}{l}0.90 \\
0.87 \\
0.96 \\
0.95 \\
0.85 \\
0.85\end{array}$ & $\begin{array}{l}0.90 \\
0.93 \\
0.83 \\
0.83 \\
0.84 \\
0.85\end{array}$ & $\begin{array}{l}1.00 \\
0.99 \\
1.00 \\
1.00 \\
1.00 \\
1.00 \\
1.00\end{array}$ \\
\hline $\begin{array}{l}\text { Turbine } c-1,50 \mathrm{ft} \\
\text { Turbine } c-3,50 \mathrm{ft} \\
\text { Turbine } c-5,50 \mathrm{ft} \\
\text { Turbine } c-7,50 \mathrm{ft} \\
\text { Turbine } c-9,50 \mathrm{ft} \\
\text { Turbine } c-12,50 \mathrm{ft} \\
\text { Turbine } c-14,50 \mathrm{ft} \\
\text { Turbine } c-16,50 \mathrm{ft} \\
\text { Turbine } c-18,50 \mathrm{ft}\end{array}$ & $\begin{array}{l}0.89 \\
0.87 \\
0.89 \\
0.87 \\
0.86 \\
0.91 \\
0.90 \\
0.87 \\
0.86\end{array}$ & $\begin{array}{l}0.98 \\
0.98 \\
0.98 \\
0.96 \\
0.95 \\
0.99 \\
0.99 \\
0.97 \\
0.95\end{array}$ & $\begin{array}{l}0.99 \\
0.99 \\
0.99 \\
0.99 \\
0.98 \\
0.99 \\
0.98 \\
0.98 \\
0.97\end{array}$ \\
\hline $\begin{array}{l}\text { Turbine } D-2,50 \mathrm{ft} \\
\text { Turbine } D-4,50 \mathrm{ft} \\
\text { Turbine } D-6,50 \mathrm{ft} \\
\text { Turbine } D-13,50 \mathrm{ft} \\
\text { Turbine } D-15,50 \mathrm{ft} \\
\text { Turbine } D-21,50 \mathrm{ft}\end{array}$ & $\begin{array}{l}0.86 \\
0.83 \\
0.80 \\
0.83 \\
0.80 \\
0.85\end{array}$ & $\begin{array}{l}0.94 \\
0.90 \\
0.87 \\
0.90 \\
0.87 \\
0.90\end{array}$ & $\begin{array}{l}0.98 \\
0.98 \\
0.98 \\
0.99 \\
0.99 \\
0.96\end{array}$ \\
\hline 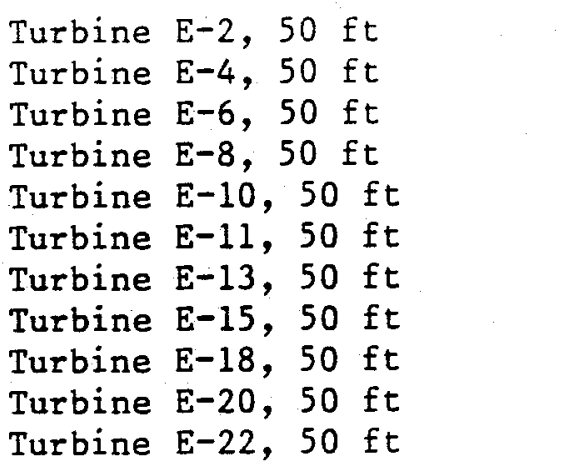 & $\begin{array}{l}0.86 \\
0.89 \\
0.86 \\
0.90 \\
0.92 \\
0.84 \\
0.85 \\
0.89 \\
0.88 \\
0.90 \\
0.93\end{array}$ & $\begin{array}{l}0.91 \\
0.93 \\
0.90 \\
0.88 \\
0.93 \\
0.89 \\
0.91 \\
0.93 \\
0.92 \\
0.90 \\
0.94\end{array}$ & $\begin{array}{l}0.96 \\
0.96 \\
0.95 \\
0.95 \\
0.97 \\
0.98 \\
0.98 \\
0.95 \\
0.95 \\
0.97 \\
0.97\end{array}$ \\
\hline $\begin{array}{l}\text { Turbine } F-1,35 \mathrm{ft} \\
\text { Turbine } F-3,35 \mathrm{ft} \\
\text { Turbine } F-7,35 \mathrm{ft} \\
\text { Turbine } F-9,35 \mathrm{ft} \\
\text { Turbine } F-12,35 \mathrm{ft}\end{array}$ & $\begin{array}{l}0.85 \\
0.88 \\
0.83 \\
0.78 \\
0.76\end{array}$ & $\begin{array}{l}0.87 \\
0.88 \\
0.88 \\
0.84 \\
0.83\end{array}$ & $\begin{array}{l}0.97 \\
0.97 \\
0.98 \\
0.98 \\
0.99\end{array}$ \\
\hline
\end{tabular}


Table 3-2. Jess Ranch Hourly Correlation Coefficients to Reference Anemometers and Adjacent Sites (Continued)

\begin{tabular}{|c|c|c|c|}
\hline $\begin{array}{l}\text { Location and: } \\
\text { Level }\end{array}$ & $J-08$ & $J-04$ & $\begin{array}{c}\text { Ad jacent } \\
\text { Site }\end{array}$ \\
\hline $\begin{array}{l}\text { Turbine G-1, } 35 \mathrm{ft} \\
\text { Turbine G-3, } 35 \mathrm{ft} \\
\text { Turbine G-5, } 35 \mathrm{ft} \\
\text { Turbine G-7, } 35 \mathrm{ft} \\
\text { Turbine G-8, } 35 \mathrm{ft} \\
\text { Turbine G-10, } 35 \mathrm{ft} \\
\text { Turbine G-12, } 35 \mathrm{ft}\end{array}$ & $\begin{array}{l}0.84 \\
0.90 \\
0.97 \\
0.99 \\
0.81 \\
0.88 \\
0.94\end{array}$ & $\begin{array}{l}0.86 \\
0.86 \\
0.87 \\
0.87 \\
0.81 \\
0.84 \\
0.87\end{array}$ & $\begin{array}{l}0.96 \\
0.96 \\
0.98 \\
0.98 \\
0.95 \\
0.97 \\
0.97\end{array}$ \\
\hline $\begin{array}{l}\text { Turbine } H-1,50 \mathrm{ft} \\
\text { Turbine } H-2,50 \mathrm{ft} \\
\text { Turbine } H-7,50 \mathrm{ft} \\
\text { Turbine } H-10,50 \mathrm{ft} \\
\text { Turbine } H-12,50 \mathrm{ft} \\
\text { Turbine } H-15,50 \mathrm{ft}\end{array}$ & $\begin{array}{l}0.85 \\
0.85 \\
0.86 \\
0.83 \\
0.83 \\
0.83\end{array}$ & $\begin{array}{l}0.94 \\
0.95 \\
0.93 \\
0.88 \\
0.91 \\
0.88\end{array}$ & $\begin{array}{l}1.00 \\
1.00 \\
0.97 \\
0.97 \\
0.94 \\
0.94\end{array}$ \\
\hline $\begin{array}{l}\text { Turbine } \mathrm{I}-1,50 \mathrm{ft} \\
\text { Turbine } \mathrm{I}-3,50 \mathrm{ft} \\
\text { Turbine } \mathrm{I}-5,50 \mathrm{ft} \\
\text { Turbine } \mathrm{I}-9,50 \mathrm{ft} \\
\text { Turbine } \mathrm{I}-14,50 \mathrm{ft}\end{array}$ & $\begin{array}{l}0.83 \\
0.82 \\
0.83 \\
0.81 \\
0.82\end{array}$ & $\begin{array}{l}0.87 \\
0.86 \\
0.87 \\
0.86 \\
0.85\end{array}$ & $\begin{array}{l}0.99 \\
0.99 \\
0.99 \\
0.96 \\
0.96\end{array}$ \\
\hline $\begin{array}{l}\text { Turbine } J-6,50 \mathrm{ft} \\
\text { Turbine } J-8,50 \mathrm{ft} \\
\text { Turbine } J-11,50 \mathrm{ft} \\
\text { Turbine } J-13,50 \mathrm{ft}\end{array}$ & $\begin{array}{l}0.87 \\
0.86 \\
0.86 \\
0.84\end{array}$ & $\begin{array}{l}0.86 \\
0.88 \\
0.86 \\
0.85\end{array}$ & $\begin{array}{l}0.97 \\
0.97 \\
0.98 \\
0.98\end{array}$ \\
\hline $\begin{array}{l}\text { Turbine } \mathrm{k}-1,35 \mathrm{ft} \\
\text { Turbine } \mathrm{K}-3,35 \mathrm{ft} \\
\text { Turbine } \mathrm{K}-5,35 \mathrm{ft} \\
\text { Turbine } \mathrm{k}-7,35 \mathrm{ft} \\
\text { Turbine } \mathrm{K}-9,35 \mathrm{ft} \\
\text { Turbine } \mathrm{k}-12,35 \mathrm{ft} \\
\text { Turbine } \mathrm{k}-14,35 \mathrm{ft}\end{array}$ & $\begin{array}{l}0.82 \\
0.84 \\
0.90 \\
0.95 \\
0.97 \\
0.94 \\
0.96\end{array}$ & $\begin{array}{l}0.84 \\
0.87 \\
0.86 \\
0.84 \\
0.85 \\
0.84 \\
0.82\end{array}$ & $\begin{array}{l}0.95 \\
0.96 \\
0.96 \\
0.97 \\
0.97 \\
0.98 \\
0.98\end{array}$ \\
\hline $\begin{array}{l}\text { Turbine } L-1,35 \mathrm{ft} \\
\text { Turbine L-3, } 35 \mathrm{ft} \\
\text { Turbine } L-5,35 \mathrm{ft} \\
\text { Turbine L-8, } 35 \mathrm{ft} \\
\text { Turbine L-10, } 35 \mathrm{ft} \\
\text { Turbine L-12, } 35 \mathrm{ft}\end{array}$ & $\begin{array}{l}0.99 \\
1.00 \\
1.00 \\
0.99 \\
1.00 \\
0.99\end{array}$ & $\begin{array}{l}0.88 \\
0.90 \\
0.91 \\
0.88 \\
0.89 \\
0.89\end{array}$ & $\begin{array}{l}0.99 \\
1.00 \\
0.99 \\
0.99 \\
1.00 \\
1.00\end{array}$ \\
\hline $\begin{array}{l}\text { Turbine } M-2,35 \mathrm{ft} \\
\text { Turbine } M-4,35 \mathrm{ft} \\
\text { Turbine } M-6,35 \mathrm{ft} \\
\text { Turbine } M-8,35 \mathrm{ft} \\
\text { Turbine } M-9,35 \mathrm{ft}\end{array}$ & $\begin{array}{l}0.97 \\
0.98 \\
0.99 \\
0.99 \\
0.96\end{array}$ & $\begin{array}{l}0.85 \\
0.88 \\
0.89 \\
0.89 \\
0.86\end{array}$ & $\begin{array}{l}0.99 \\
0.99 \\
1.00 \\
1.00 \\
0.99\end{array}$ \\
\hline
\end{tabular}


Table 3-2. Jess Ranch Hourly Correlation Coefficients to Reference Anemometers and Ad jacent Sites (Concluded)

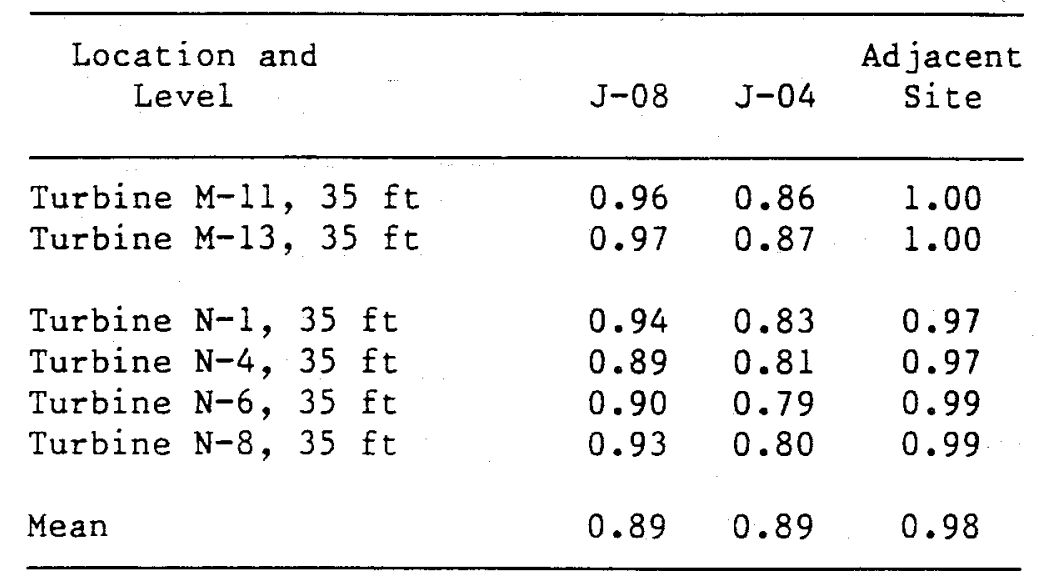

The data 1 isted in Table 3-2 are plotted on Figures $3-2$ and 3-3. Figure 3-2 shows the correlations to $\mathrm{J}-08$, and Figure $3-3$ shows the correlations to J-04. Both figures show the areas of high correlation in the vicinity of the reference tower used. Well-exposed sites such as L-3, L-5, and C-10 through C-14 show good correlations to both towers. Figure 3-2 shows that there are two areas with relatively low correlation coefficients to J-08. These two areas are downwind of hills on the adjacent ranch. The hills are marked with " $X$ ". Evidently, the hills act as obstacles to the flow. The low correlations at these sites indicate a relatively high degree of variability in the wind in these two small areas. Site F-12, in the northern area, had the lowest correlation coefficient to site J-08.

Additional analysis was done to determine the effect of inversion height on the degree of correlation. Inversion height data were collected on the Souza Ranch by Howden Wind Parks Inc. These data were made available by Howden. The analysis showed that for low inversion heights, with an inversion top below $1000 \mathrm{ft}$ MSL, the correlation coefficient at F-12 drops to 0.56 . However, when the inversion top is above $1000 \mathrm{ft} \mathrm{MSL}$, the correlation coefficient jumps to 0.91 . For comparison, site $M-13$ was analyzed, which is in the northeast portion of the Jess study area and not downwind of the 678-ft hill. This site has a correlation coefficient of 0.97 for both low and high inversions, so the inversion has no effect on the correlation at this site. This exercise illustrates the combined effect of the low inversion and the topography. When the inversion is low, the wind at sites such as F-12 is highly variable; this variability is a local effect, not seen at J-08. This variability may be caused partially by wave activity within the inversion. The inversion rises and falls, and as it does, flow over the 678-ft hill may be interrupted. The result could be that the wind might come in spurts downwind of this hill whenever the right combination of inversion height and wave activity occurs. When the inversion is higher the flow over the entire Jess Ranch is deeper. This leads to a more homogeneous wind resource over the ranch because the hills upwind do not obstruct the flow significantly. 


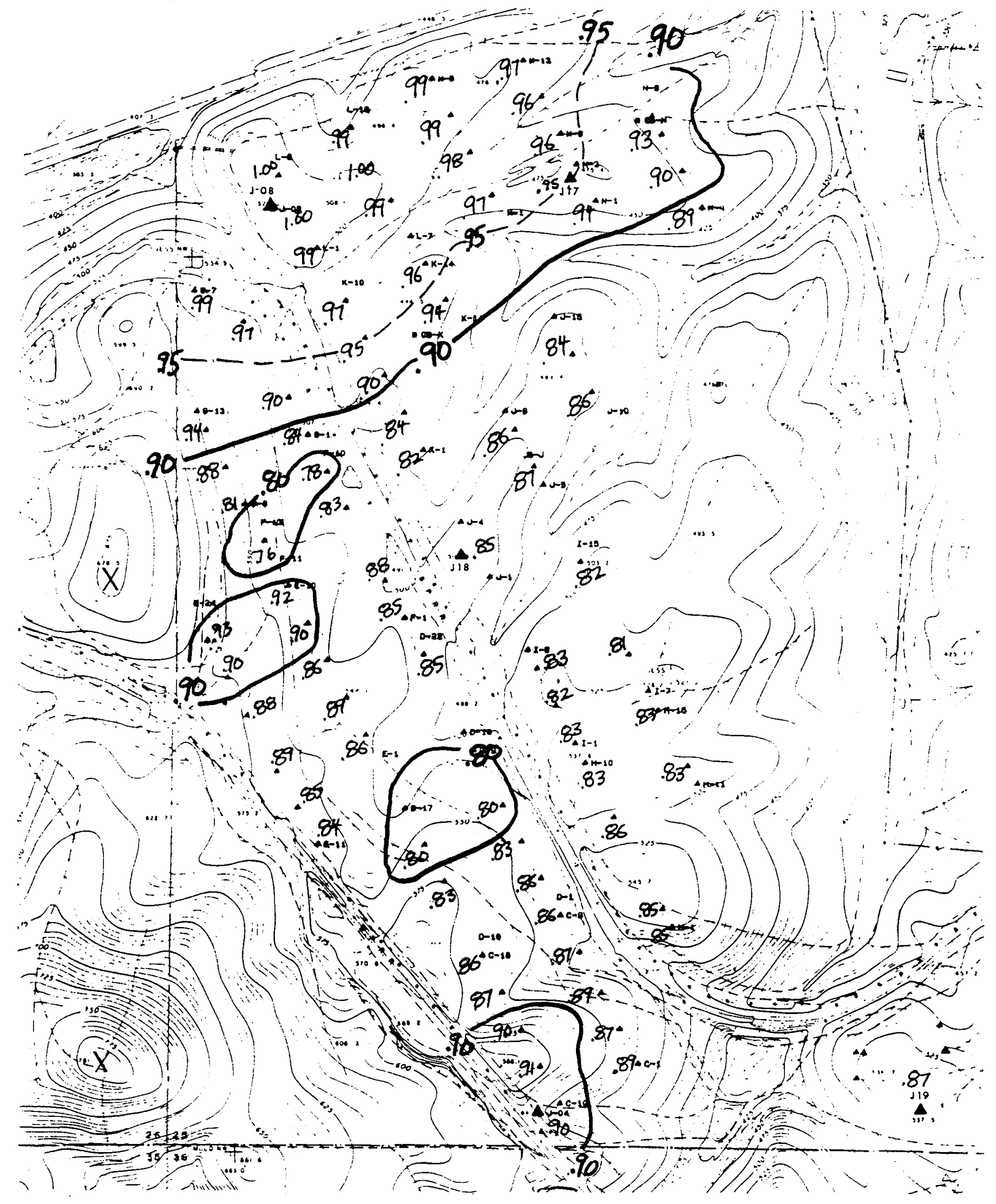

Figure 3-2. Hourly Correlation Coefficient ( $r$ ) to Site J-08 


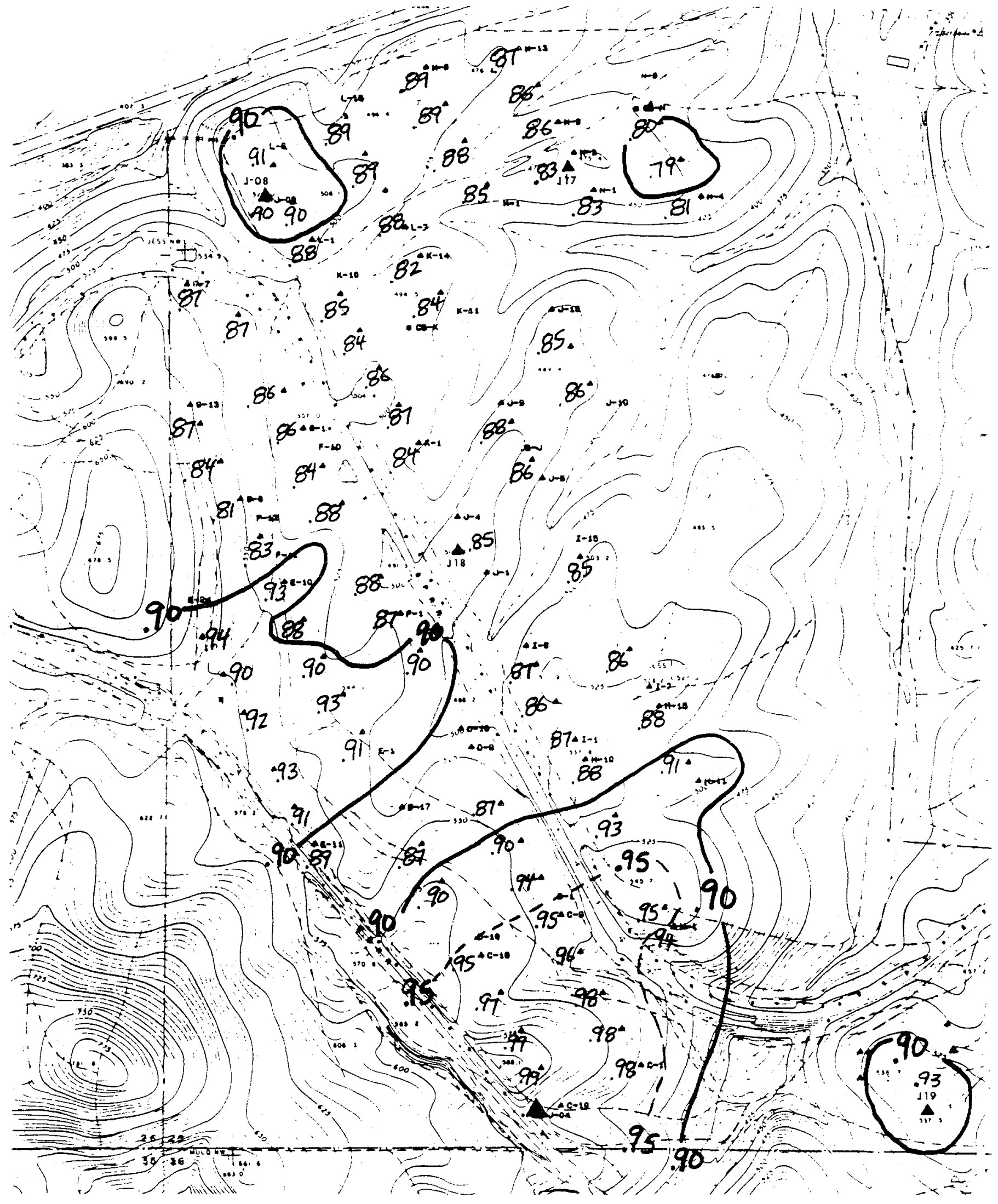

Figure 3-3. Hourly Correlation Coefficient $(r)$ to Site J-04 
This type of analysis was not done on Souza for two reasons: (1) the correlation coefficients to the reference tower were all quite high on Souza, and (2) the mean height of the inversion was considerably higher during the Souza free-flow period than it was during the Jess period. It is believed that the higher inversion during the souza study is responsible, in part, for the higher correlation coefficients on Souza.

\subsection{Wind Roses}

Tables 3-3 and 3-4 are joint-frequency distributions of wind speed and direction for sites $\mathrm{S}-13$ and $\mathrm{J}-08$, respectively. The data are grouped in 5-mph speed bins and $5^{\circ}$ direction bins. Table 3-3 shows that wind directions ranged from $210^{\circ}$ to $255^{\circ}$, south-southwest through west-southwest. Table 3-3 also shows that almost all the data fall in a $15^{\circ}$ band from $220^{\circ}$ to $235^{\circ}$. This is typical of spring/summer flow at site s-13. The table shows that most of the hourly mean speeds were between 20 and $30 \mathrm{mph}$.

Table 3-3. S-13 Joint Frequency Distribution. Hours of Occurrence at the 70-ft Level (Sept. 10-14, 1987).

\begin{tabular}{ccccccccc}
\hline \multirow{2}{*}{$\begin{array}{c}\text { Wind } \\
\text { Direction } \\
\text { (Degrees) }\end{array}$} & 10 & 15 & 20 & 25 & 30 & 35 & 40 & \\
& to & to & to & to & to & to & to & Total \\
& 15 & 20 & 25 & 30 & 35 & 40 & 45 & \\
\hline $210-215$ & - & - & 2 & - & - & - & - & 2 \\
$215-220$ & - & 2 & 4 & 3 & - & - & - & 9 \\
$220-225$ & 1 & 4 & 8 & 7 & 2 & - & - & 22 \\
$225-230$ & - & 4 & 10 & 12 & 4 & 4 & - & 34 \\
$230-235$ & - & 4 & 2 & 4 & 4 & 4 & 1 & 19 \\
$235-240$ & 1 & 1 & - & - & - & 1 & - & 3 \\
$240-245$ & 1 & - & - & - & - & - & - & 1 \\
$245-250$ & 1 & - & - & - & - & - & - & 1 \\
$250-255$ & 3 & - & - & - & - & - & - & 3 \\
Total & 7 & 15 & 26 & 26 & 10 & 9 & 1 & 94 \\
\hline
\end{tabular}

Note: Values in a category are greater than or equal to the lower bound, and less than the upper bound of the category.

Table 3-4 shows that there was a narrower range of directions at J-08, from $235^{\circ}$ to $260^{\circ}$. Most of the hours fall in a $15^{\circ}$ band, from $240^{\circ}$ to $255^{\circ}$, or west-southwest. This is the normal spring/summer direction at this site. The table also shows that most of the speeds were between 20 and $30 \mathrm{mph}$. 
Table 3-4. J-08 Joint Frequency Distribution. Hours of Occurrence at the 50-ft Leve1 (Oct. 1-10, 1987).

\begin{tabular}{|c|c|c|c|c|c|c|c|c|c|c|c|c|c|c|}
\hline \multirow{2}{*}{$\begin{array}{l}\text { Wind } \\
\text { Direction } \\
\text { (Degrees) }\end{array}$} & \multicolumn{14}{|c|}{ Wind Speed (mph) } \\
\hline & 10 & to 15 & 15 & to 20 & 20 & to 25 & 25 & to: & 30 & 30 & to 35 & 35 & to 40 & Total \\
\hline $235-240$ & & - & & 1 & & - & & 2 & & & 1 & & - & 4 \\
\hline $240-245$ & & 1 & & 4 & & 9 & & 11 & & & 3 & & 1 & 29 \\
\hline $245-250$ & & 2 & & 2 & & 7 & & 12 & & & 4 & & 4 & 31 \\
\hline $250-255$ & & 2 & & 5 & & 8 & & 11 & & & 3 & & 2 & 31 \\
\hline $255-260$ & & 2 & & 3 & & 1 & & 1 & & & - & & - & 7 \\
\hline Total & & 7 & & 15 & & 25 & & 37 & & & 11 & & 7 & 102 \\
\hline
\end{tabular}

Note: Values in a category are greater than or equal to the lower bound, and less than the upper bound of the category.

\subsection{Diurnal Mean Speeds}

Table 3-5 lists the diurnal (time-of-day) mean speeds for the Souza and Jess reference sites. Note that each diurnal average contains only four or five

Table 3-5. Diurnal Mean Wind Speeds

\begin{tabular}{ccc} 
& \multicolumn{2}{c}{ Wind Speed $(\mathrm{mph})$} \\
\cline { 2 - 3 } Hour & $\mathrm{S}-13$ & $\mathrm{~J}-08$ \\
\hline 01 & 29.5 & 27.0 \\
02 & 26.9 & 25.4 \\
03 & 25.5 & 24.6 \\
04 & 24.5 & 21.7 \\
05 & 24.6 & 19.9 \\
06 & 24.8 & 21.9 \\
07 & 23.7 & 20.9 \\
08 & 23.7 & 21.5 \\
09 & 23.4 & 23.2 \\
10 & 22.6 & 26.6 \\
11 & 19.6 & 26.0 \\
12 & 18.3 & 25.6 \\
13 & 18.3 & 24.8 \\
14 & 18.8 & 25.6 \\
15 & 20.6 & 25.5 \\
16 & 20.7 & 26.1 \\
17 & 21.3 & 24.7 \\
18 & 24.8 & 26.0 \\
19 & 27.6 & 25.6 \\
20 & 32.8 & 26.1 \\
21 & 34.5 & 27.3 \\
22 & 32.4 & 28.1 \\
23 & 30.7 & 28.7 \\
24 & 31.3 & 27.4 \\
Mean & 25.1 & 25.0 \\
\hline
\end{tabular}


hours of data, so the typical diurnal pattern may not be reflected in the data. The data from S-13 show the typical diurnal pattern of an Altamont site: highest winds just before midnight and lowest winds around noon. The data from the midday lulls at J-08 on October 2, 3, and 10 were deleted from the data set. Thus, J-08 does not show this pattern.

A complete listing of the diurnal mean speeds at all sites can be found in Appendix D. These summaries are interesting because they allow a comparison of different sites' diurnal patterns and mean speeds.

\subsection{Vertical Shear}

In all, five two-level towers were available for this study, three on Jess and two on Souza. Vertical wind shear is often expressed as an exponent, alpha. Normally, in neutral atmospheric stability in areas of flat terrain, alpha is equal to $1 / 7$ or about 0.14 . Because of the inversion (which results in high stability) and the complex terrain, vertical shear in the Altamont Pass varies considerably from this value and is often less than 0.14. In the Altamont Pass, alpha values are generally very low on well-exposed ridges and higher at sheltered sites. The low values on well-exposed sites are because of speed-up effects near the ground.

Alpha has been calculated for each hour of data at all five towers. Table 3-6 is a diurnal summary of these data. (Note that the units in the table are "100 or \%," so all values have been multiplied by 100 . Thus, an alpha of 14.0 in the table is actually 0.14.) The table shows that all five towers have alpha values below 0.14 . On the Jess Ranch, the mean of the alpha values ranged from 0.114 at site J-18 to a low of 0.058 at J-19. Site J-19 is on a well-exposed knoll, which helps explain its lower shear.

There is no clear diurnal pattern shared by all sites. $\mathrm{J}-18$ and $\mathrm{J}-19$ have lower shear in the midday than at night. Shear often increases after sunset as the lack of thermal instability creates less downward mixing of momentum. Because of the lack of mixing at night, flow lifts or separates from the ground, resulting in stronger shear. This phenomenon has beendiscussed quite extensively in meteorological and air-quality literature.

The Souza sites also have mean alpha values below 0.14 . In fact, site s-27 has a mean shear close to zero, indicating that wind speeds are the same at both levels. Site S-13's shear is larger, 0.075 , and is about half the "normal" value.

As noted in Section 2.2.1, there were two turbine anemometer heights on the Jess Ranch: 35 and $50 \mathrm{ft}$ AGL. The vertical shear measured at the three Jess two-level towers suggests that the speed difference between 35 and $50 \mathrm{ft}$ would be $2 \%-4 \%$.

\subsection{Wind-Speed Frequency Distribution and Theoretical Energy}

Theoretical energy production is calculated by integrating the measured frequency distribution over a given time period and by using a power curve. This calculation has been done for the two reference sites, with the Nordtank power curve. In the calculation, the power curve has been adjusted to $97 \%$ of sealevel density, which is a close approximation based on the altitude and temperature. Wind-speed data at $\mathrm{S}-13$ were collected at hub height, so no shear 
Table 3-6. Diurnal Wind Shear Summary. Units are Shear Exponent, Alpha $\times 100$.

\begin{tabular}{|c|c|c|c|c|c|}
\hline \multirow[b]{2}{*}{ Hour } & \multicolumn{3}{|c|}{$\begin{array}{l}\text { Jess Ranch Sites } \\
\text { (Oct. } 1-10,1987 \text { ) }\end{array}$} & \multicolumn{2}{|c|}{$\begin{array}{c}\text { Souza Ranch Sites } \\
\text { (Sept. 10-14, 1987) }\end{array}$} \\
\hline & $\mathrm{J}-17$ & $\mathrm{~J}-18$ & $\overline{J-19}$ & $s-13$ & $s-27$ \\
\hline 1 & 9.3 & 11.0 & 6.0 & 7.5 & -0.7 \\
\hline 2 & 9.0 & 13.0 & 4.9 & 5.4 & -0.9 \\
\hline 3 & 10.3 & 13.8 & 5.6 & 5.7 & -0.1 \\
\hline 4 & 8.9 & 15.4 & 7.8 & 6.0 & 0.4 \\
\hline 5 & 9.5 & 17.1 & 7.5 & 5.9 & 0.2 \\
\hline 6 & 10.0 & 22.2 & 9.0 & 5.8 & 1.0 \\
\hline 7 & 9.4 & 9.5 & 7.6 & 7.4 & 1.8 \\
\hline 8 & 12.7 & 21.3 & 7.5 & 7.7 & 1.3 \\
\hline 9 & 10.0 & 12.6 & 7.6 & 8.0 & -0.2 \\
\hline 10 & 6.0 & 9.2 & 3.3 & 8.1 & -0.3 \\
\hline 11 & 10.7 & 9.0 & 6.4 & 8.3 & -1.6 \\
\hline 12 & 10.8 & 7.6 & 2.6 & 7.5 & -2.3 \\
\hline 13 & 5.4 & 6.8 & 0.6 & 6.3 & -1.4 \\
\hline 14 & 11.4 & 6.5 & 1.9 & 7.2 & -1.6 \\
\hline 15 & 11.7 & 6.7 & -0.5 & 10.8 & 0.1 \\
\hline 16 & 11.3 & 6.1 & 2.1 & 8.9 & -0.7 \\
\hline 17 & 11.4 & 6.7 & 1.7 & 10.0 & -0.1 \\
\hline 18 & 11.4 & 8.3 & 4.8 & 9.7 & -0.2 \\
\hline 19 & 13.2 & 10.5 & 7.1 & 9.4 & 1.3 \\
\hline 20 & 12.4 & 12.9 & 7.4 & 7.3 & 2.9 \\
\hline 21 & 12.8 & 9.7 & 7.4 & 6.2 & 2.5 \\
\hline 22 & 11.3 & 9.8 & 7.9 & 6.4 & -0.1 \\
\hline 23 & 10.6 & 10.0 & 8.6 & 6.9 & -0.1 \\
\hline 24 & 10.3 & 10.3 & 7.7 & 8.2 & 1.0 \\
\hline Mean & 10.5 & 11.4 & 5.8 & 7.5 & 0.1 \\
\hline \multicolumn{6}{|l|}{ Valid } \\
\hline hours & 102 & 102 & 102 & 94 & 94 \\
\hline
\end{tabular}

Note: Measurement levels for sites $\mathrm{J}-17, \mathrm{~J}-18$, and S-13 were $35 \mathrm{ft}$ and $70 \mathrm{ft}$. Measurement levels for site J-19 were $40 \mathrm{ft}$ and $80 \mathrm{ft}$. Measurement levels for sites $\mathrm{S}-27$ were $45 \mathrm{ft}$ and $80 \mathrm{ft}$.

adjustment is necessary. J-08 data were collected at $50 \mathrm{ft}$, which is $22 \mathrm{ft}$ below hub height. However, based on the excellent exposure of J-08 (on a bluff), the shear between 50 and $72 \mathrm{ft}$ AGL is probably negligible; therefore, no correction has been made.

Tables $3-7$ and $3-8$ are the distributions for $\mathrm{s}-13$ and $\mathrm{J}-08$, respectively. The tables show that theoretical energy at these sites during the free-flow period was about $4300 \mathrm{kWh}$ at $\mathrm{s}-13$ and about $4700 \mathrm{kWh}$ at $\mathrm{J}-08$. 


\section{Table 3-7. Wind Speed Frequency \\ Distribution for site \\ s-13. 70-ft Reference, \\ Sept. 10-14, 1987 .}

\begin{tabular}{|c|c|c|c|}
\hline \multirow[b]{2}{*}{$\begin{array}{l}\text { Speed* } \\
\text { (mph) }\end{array}$} & \multirow[b]{2}{*}{ Hours } & \multicolumn{2}{|c|}{ Nordtank 65} \\
\hline & & $\begin{array}{c}\text { Power:" } \\
(\mathrm{kW})\end{array}$ & $\begin{array}{c}\text { Energy } \\
(\mathrm{kWh})\end{array}$ \\
\hline 10 & 0 & 2.2 & 0.0 \\
\hline 11 & 0 & 4.5 & 0.0 \\
\hline 12 & 0 & 6.8 & 0.0 \\
\hline 13 & 3 & 9.4 & 28.1 \\
\hline 14 & 3 & 12.0 & 35.9 \\
\hline 15 & 2 & 14.5 & 29.1 \\
\hline 16 & 2 & 18.6 & 37.2 \\
\hline 17 & 0 & 22.7 & 0.0 \\
\hline 18 & 1 & 26.8 & 26.8 \\
\hline 19 & 5 & 30.8 & 154.2 \\
\hline 20 & 8 & 34.9 & 279.4 \\
\hline 21 & 5 & 38.0 & 190.1 \\
\hline 22 & 4 & 41.1 & 164.5 \\
\hline 23 & 7 & 44.2 & 309.6 \\
\hline 24 & 6 & 47.3 & 284.0 \\
\hline 25 & 6 & 50.4 & 302.6 \\
\hline 26 & 3 & 52.1 & 156.2 \\
\hline 27 & 8 & 53.7 & 429.4 \\
\hline 28 & 4 & 55.3 & 221.2 \\
\hline 29 & 6 & 56.9 & 341.4 \\
\hline 30 & 1 & 58.5 & 58.5 \\
\hline 31 & 5 & 60.1 & 300.7 \\
\hline 32 & 0 & 60.7 & 0.0 \\
\hline 33 & 2 & 61.4 & 122.7 \\
\hline 34 & 2 & 62.0 & 123.9 \\
\hline 35 & 3 & 62.6 & 187.7 \\
\hline 36 & 3 & 63.2 & 189.5 \\
\hline 37 & 1 & 63.8 & 63.8 \\
\hline 38 & 3 & 64.4 & 193.2 \\
\hline 39 & 0 & 66.0 & 0.0 \\
\hline $40-60$ & 1 & 67.0 & 67.0 \\
\hline Total & 94 & & 4296.8 \\
\hline
\end{tabular}

*Mean wind speed $=25.1 \mathrm{mph}$.

$*$ Corrected to $97.0 \%$ density. 
Table 3-8. Wind speed Frequency Distribution for Site J-08. 50-ft Reference, Oct. $1-10,1987$.

\begin{tabular}{cccc}
\hline & & \multicolumn{2}{c}{ Nordtank 65} \\
$\begin{array}{c}\text { Speed } \\
\text { (mph) }\end{array}$ & Hours & $\begin{array}{c}\text { Power } \\
(\mathrm{kW})\end{array}$ & $\begin{array}{c}\text { Energy } \\
(\mathrm{kWh})\end{array}$ \\
\hline 10 & 0 & 2.2 & 0.0 \\
11 & 1 & 4.5 & 4.5 \\
12 & 0 & 6.8 & 0.0 \\
13 & 1 & 9.4 & 9.4 \\
14 & 2 & 12.0 & 23.9 \\
15 & 4 & 14.5 & 58.2 \\
16 & 4 & 18.6 & 74.5 \\
17 & 5 & 22.7 & 113.5 \\
18 & 3 & 26.8 & 80.3 \\
19 & 2 & 30.8 & 61.7 \\
20 & 3 & 34.9 & 104.8 \\
21 & 3 & 38.0 & 114.1 \\
22 & 3 & 41.1 & 123.4 \\
23 & 4 & 44.2 & 176.9 \\
24 & 7 & 47.3 & 331.4 \\
25 & 8 & 50.4 & 403.5 \\
26 & 9 & 52.1 & 468.5 \\
27 & 8 & 53.7 & 429.4 \\
28 & 5 & 55.3 & 276.4 \\
29 & 9 & 56.9 & 512.2 \\
30 & 4 & 58.5 & 234.1 \\
31 & 2 & 60.1 & 120.3 \\
32 & 2 & 60.7 & 121.5 \\
33 & 3 & 61.4 & 184.1 \\
34 & 2 & 62.0 & 123.9 \\
35 & 2 & 62.6 & 125.1 \\
36 & 3 & 63.2 & 189.5 \\
37 & 1 & 63.8 & 63.8 \\
38 & 1 & 64.4 & 64.4 \\
39 & 1 & 66.0 & 66.0 \\
$40-60$ & 9 & 67.0 & 0.0 \\
& & & \\
Total & 102 & & 4659.2 \\
\hline
\end{tabular}

*Mean wind speed $=25.0 \mathrm{mph}$. **:Corrected to $97.0 \%$ density.

Theoretical energy at J-08 was slightly higher, partly because of the longer integrating period ( 102 hours versus 94 hours). Thus, the two periods were quite similar in energy content at these two sites. The mean wind speeds were nearly identical also. The data periods in these two tables are not identical because the free-flow measurements took place on different dates on these two ranches. 


\subsection{Speed and Energy Ratios}

The principal analysis tool of this report was the calculation of speed ratios between the reference site and all other sites. Ratios have been calculated for the entire data set and for a number of subsets. The subsets were based on stratification by a third: parameter. The stratifications were done by the following:

1. Wind direction at the reference site

2. Wind speed at the reference site

3. Day versus night hours

4. Data period (at Jess, where there were two periods).

Theoretical energy ratios were also calculated for the entire data set, using the Nordtank 65-kW power curve.

After these various ratios were calculated, the data were plotted on topographic maps, and isopleths were drawn. The maps are an excellent vehicle for presenting this large amount of data, as the wind speed ratio patterns are quite apparent, when plotted out. In some cases, the ratios of a particular stratification class did not reveal any difference in overall pattern from the entire data set. In these cases, the maps are redundant and have not been included in this report.

\subsubsection{Souza Ranch Ratios}

Table 3-9 lists the speed ratios to $\mathrm{S}-13$ for the various stratifications, as well as the energy ratios for the entire data set. Reviewing Table 3-9 reveals that stratification by wind direction changes the ratios from the entire data set; however, stratification by speed and time of day shows fewer changes. There are four ratio maps included in this section:

1. Speed ratios to S-13 for the entire data set

2. Energy ratios to S-13 for the entire data set

3. Speed ratios for wind direction band $210^{\circ}-226^{\circ}$

4. Speed ratios for wind direction band $226^{\circ}-255^{\circ}$.

Before reviewing these figures, it is useful to look at Figure 2-2, the topographic map of the Souza Ranch and surrounding terrain. Notice the location of the canyon aligned with the southwest flow that intersects the lower left (southwest) corner of the study area.

Figure $3-4$ is a plot of the speed ratios to $\mathrm{S}-13$ for the entire data period. The wind speeds were quite uniform, except at 69 . Almost all the site ratios were within a range of $90 \%$ to $110 \%$ of S-13. There are two high-wind areas: in the west area near $G 2$ and F2-F8, and in the east area around D11 and D13. The first area is on a ridge downwind of the principal canyon axis, as mentioned above. The second area is a lower ridge jutting into a small drainage canyon (also aligned southwest). The areas with speed ratios of $100 \%$ or higher have been 1 ightly shaded on the Souza maps. All sites with ratios above $100 \%$ are on ridges that intersect or jut into small drainage canyons, aligned with the prevaiiling flow. Turbine $G 9$ is in a low-wind area that appears to be sheltered by the terrain immediately west of it. 
Table 3-9. Souza Ranch Ratios to Site S-13, 70-ft Reference Anemometer

\begin{tabular}{|c|c|c|c|c|c|c|c|c|}
\hline \multirow[b]{2}{*}{ Site } & \multicolumn{2}{|c|}{ A11 Data } & \multicolumn{6}{|c|}{ Speed Ratios by Stratification } \\
\hline & $\begin{array}{l}\text { Speed } \\
\text { Ratio }\end{array}$ & $\begin{array}{c}\text { Energy } \\
\text { Ratio }\end{array}$ & Day & Night & $\begin{array}{l}210-226 \\
\text { degrees }\end{array}$ & $\begin{array}{l}226-255 \\
\text { degrees }\end{array}$ & $\begin{array}{c}10-24.6 \\
\mathrm{mph}\end{array}$ & $\begin{array}{c}24.6-41 \\
\mathrm{mph}\end{array}$ \\
\hline$s-1335^{\prime}$ & .95 & .94 & .94 & .95 & .96 & .95 & .95 & .96 \\
\hline$s-27 \quad 45^{\prime}$ & .94 & .92 & .94 & .94 & .96 & .92 & .95 & .94 \\
\hline$S-2780^{\prime}$ & .94 & .93 & .93 & .94 & .96 & .93 & .95 & .94 \\
\hline$S-2950^{\prime}$ & .96 & .96 & .96 & .95 & .97 & .95 & .98 & .95 \\
\hline D02 $35^{\prime}$ & .96 & .96 & .97 & .96 & .98 & .95 & .98 & .95 \\
\hline D04 & .94 & .93 & .93 & .94 & .97 & .92 & .96 & .93 \\
\hline D06 & .93 & .91 & .91 & .93 & .96 & .89 & .93 & .92 \\
\hline D07 & .94 & .93 & .93 & .94 & .98 & .91 & .95 & .93 \\
\hline D11 & 1.08 & 1.09 & 1.07 & 1.09 & 1.11 & 1.06 & 1.09 & 1.08 \\
\hline D13 & 1.10 & 1.10 & 1.08 & 1.10 & 1.15 & 1.05 & 1.11 & 1.09 \\
\hline E02 & 1.03 & 1.03 & 1.02 & 1.02 & 1.07 & .99 & 1.04 & 1.02 \\
\hline E04 & .95 & .94 & .95 & .94 & .98 & .92 & .96 & .94 \\
\hline E06 & .96 & .95 & .97 & .94 & .98 & .94 & .97 & .95 \\
\hline E10 & .99 & .98 & .97 & .99 & 1.04 & .94 & .99 & .99 \\
\hline E12 & .93 & .92 & .92 & .93 & .97 & .89 & .94 & .92 \\
\hline E14 & .92 & .91 & .92 & .91 & .95 & .89 & .94 & .91 \\
\hline $\mathrm{FO} 2$ & 1.05 & 1.06 & 1.07 & 1.03 & 1.08 & 1.02 & 1.06 & 1.04 \\
\hline F04 & 1.06 & 1.07 & 1.08 & 1.04 & 1.07 & 1.05 & 1.08 & 1.05 \\
\hline F06 & 1.11 & 1.11 & 1.13 & 1.09 & 1.12 & 1.10 & 1.12 & 1.10 \\
\hline F08 & 1.06 & 1.07 & 1.08 & 1.05 & 1.09 & 1.04 & 1.07 & 1.06 \\
\hline F 10 & .98 & .97 & .99 & .98 & .99 & .98 & .98 & .98 \\
\hline F12 & 1.02 & 1.01 & 1.01 & 1.02 & 1.02 & 1.01 & 1.01 & 1.02 \\
\hline F14 & .98 & .95 & .95 & .99 & .98 & .97 & .96 & .99 \\
\hline G02 & 1.05 & 1.05 & 1.06 & 1.03 & 1.06 & 1.03 & 1.06 & 1.05 \\
\hline G04 & .98 & .97 & .97 & .8 & .99 & .97 & .98 & .98 \\
\hline G07 & .92 & .88 & .89 & .93 & .94 & .89 & .90 & .93 \\
\hline G09 & .77 & .68 & .75 & .78 & .80 & .74 & .76 & .78 \\
\hline Mean & .98 & .97 & .98 & .98 & 1.01 & .96 & .99 & .98 \\
\hline
\end{tabular}

Figure $3-5$ is a plot of the theoretical energy ratios for the entire data period. The pattern is the same as that of Figure 3-4. Note that no shear adjustments were made to correct the $35-\mathrm{ft}$ data to hub height ( $72 \mathrm{ft}$ ). Vertical-shear data for the Souza sites were discussed in Section 3.5. As mentioned, site S-13's shear was about one-half the "normal" value of 0.14 (for flat terrain) and $S-27^{\prime} \mathrm{s}$ shear was about zero. At sites that are not on the tops of well-exposed ridges, shear values may be close to 0.14 . This is probably true at many of the "E" sites, which are on terrain that slopes gently down behind a ridge. Therefore, the energy ratios on Figure 3-5 may be artificially low at these sites. However, trying to estimate wind shear at individual sites is difficult; the resulting errors could be larger than if simply presenting the data as-is.

Figure 3-6 is a plot of speed ratios for the more south-southwesterly winds $\left(210^{\circ}-226^{\circ}\right)$. The ratios are about 3\% higher overall than on Figure $3-4$, but the general pattern is the same. Figure 3-7 is a plot of the speed ratios for 


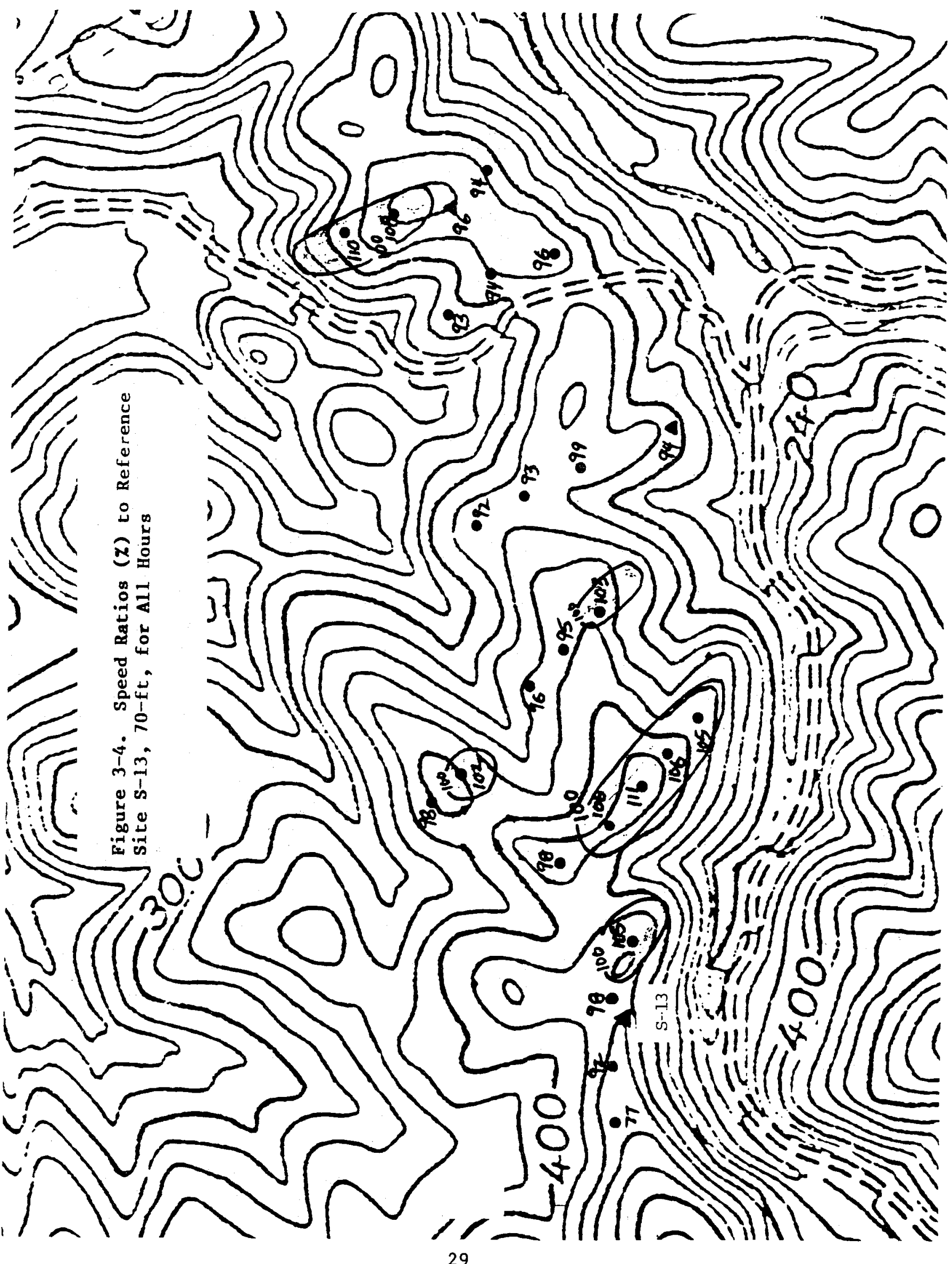




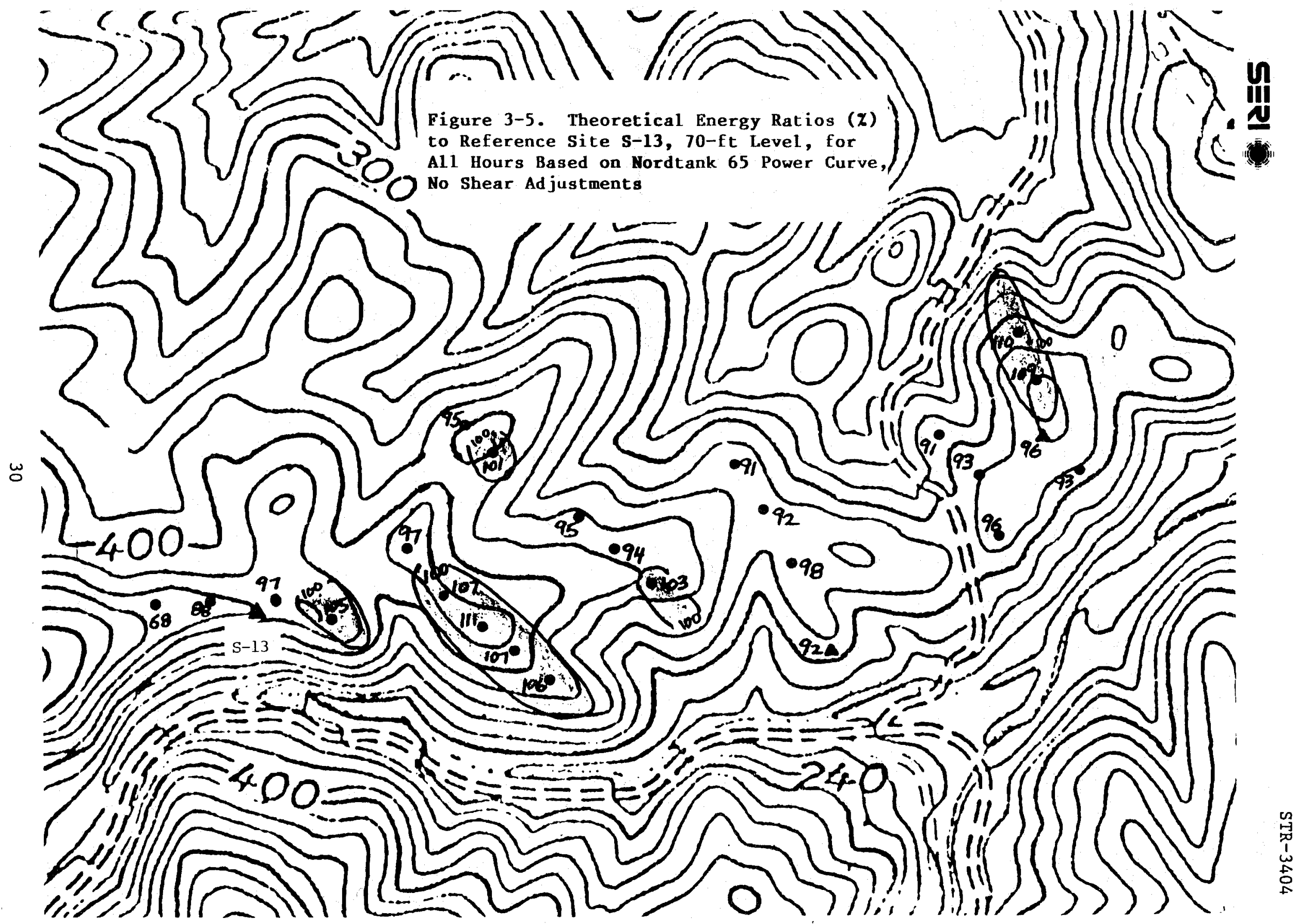




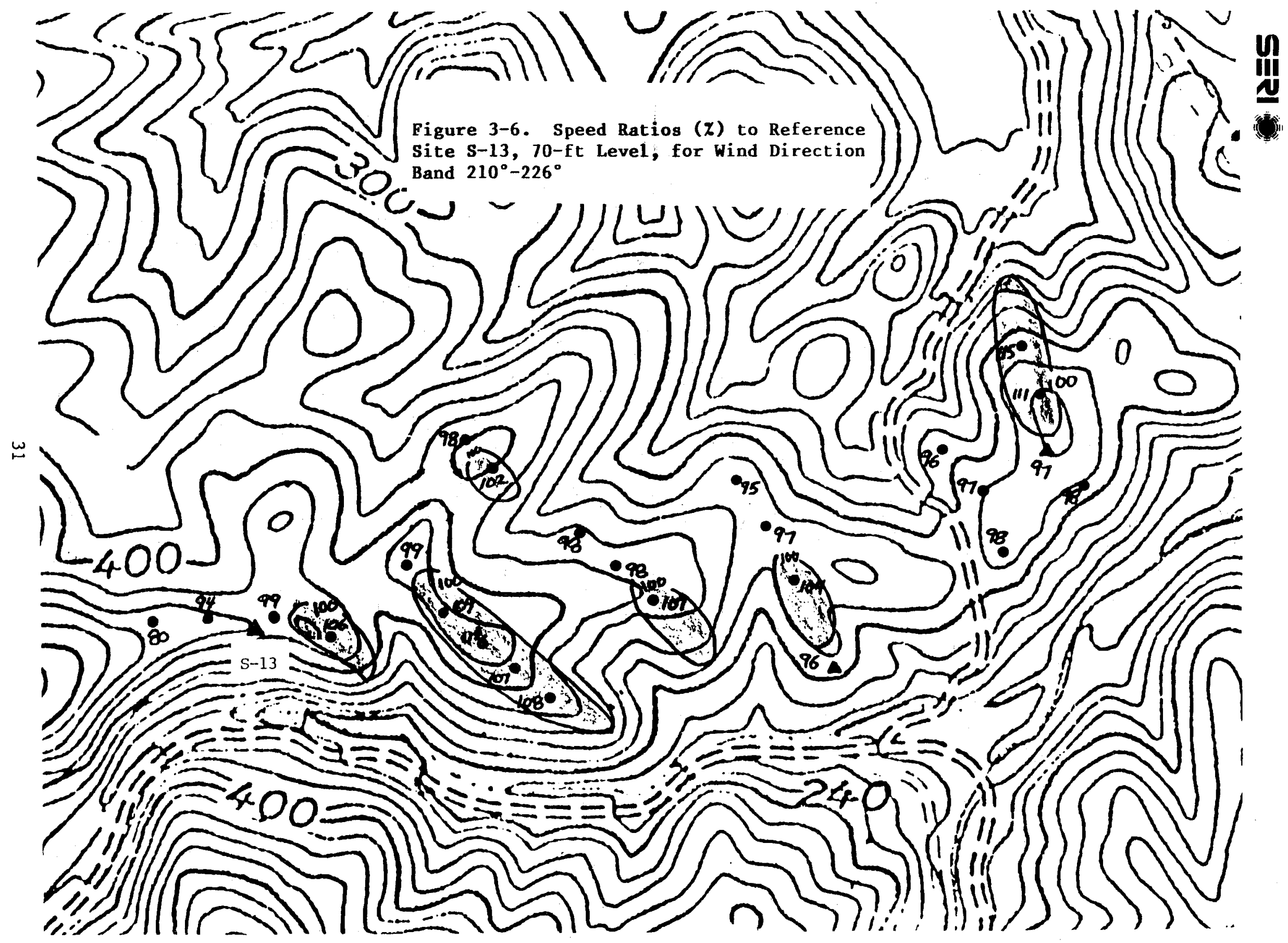




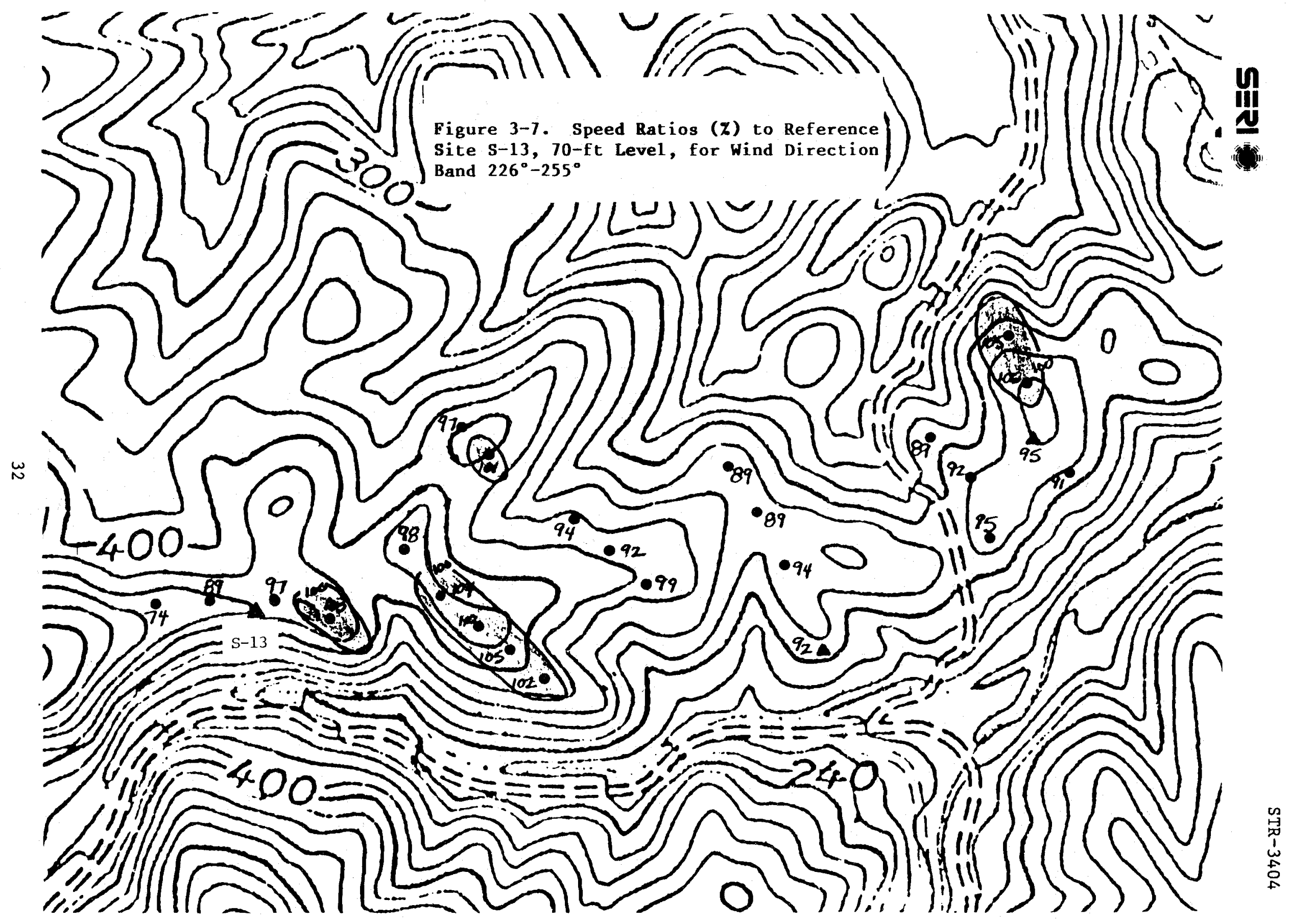


the more west-southwesterly winds $\left(226^{\circ}-255^{\circ}\right)$. The ratios are about $2 \%$ lower overall than those of Figure $3-4$ and $5 \%$ lower than those of Figure 3-6.

\subsubsection{Jess Ranch Ratios}

Table 3-10 lists the speed ratios to J-08 for the various stratification classes, as well as the energy ratios for the entire data set. The speed ratios are for anemometer height and have not been normalized, except for those for site J-04. The ratios from the four sites that had some invalid data points are calculated from the data sets that include the surrogate data. As with Souza, the stratification by wind direction changes the ratios more than does stratification by wind speed or time of day. The first data period, October 1-3, was characterized by somewhat weaker flow, and it also shows numerous changes in the speed ratios relative to the entire data set. Thus, there are five ratio maps included in this section:

1. Speed ratios to J-08 for the entire data set

2. Energy ratios to J-08 for the entire data set

3. Speed ratios for wind direction band $210^{\circ}-247^{\circ}$

4. Speed ratios for wind direction band $247^{\circ}-262^{\circ}$

5. Speed ratios for the October $1-3$ data period.

Before reviewing the figures, it is useful to refer back to Figure 2-1 to study the upwind terrain. Notice the locations of the canyons aligned with the southwest flow, upwind of the ranch. Two large canyons and one small canyon should be noted. The largest canyon intersects the southern border of the study area and continues southwest for two miles, through sections 35 and 2 . A second large canyon, which contains the southern lanes of Interstate 580 , is west of the northern part of the study area. A small, third canyon can be seen in the southeast portion of Section 26 . The canyons are marked with arrows. One additional terrain feature is the $681-\mathrm{ft}$ hill upwind of Jess just west of the area marked "Cayley." This is the same hill discussed in section 3.2.2, the Jess correlation discussion.

Figure 3-8 is a plot of the speed ratios to J-08. All ratios are based on data from $35-\mathrm{ft}$ or $50-\mathrm{ft}$ levels with the following caveats.

1. J-04 is adjusted from $120 \mathrm{ft}$ to $50 \mathrm{ft}$ using an alpha of 0.10 . This value of alpha is considered a good estimate because J-04 is located in a slight depression. This terrain feature would result in a higher alpha than that measured at nearby site $\mathrm{J}-19$, which has an alpha of about 0.06 .

2. J-19 data is actually from $40 \mathrm{ft}$ (unadjusted).

3. J-08 data is actually from $50 \mathrm{ft}$ (unadjusted).

4. Ratios for the 35-ft turbine anemometer are adjusted to the 50-ft level using an alpha of 0.10 . Data collected on turbines on the northern half of the ranch were at $35 \mathrm{ft}$, versus $50 \mathrm{ft}$ on the southern half. It is possible that using an alpha of 0.10 could yield a speed ratio error of $\pm 3 \%$ based on the expected range of shear values at these sites. Using an al pha of 0.10 is considered a good compromise based on data from J-17 and $\mathrm{J}-18$. 
Table 3-10. Jess Ranch Eree-Elow Data Analysis

Speed and Energy Ratios to Site J-08 for different stratification classes

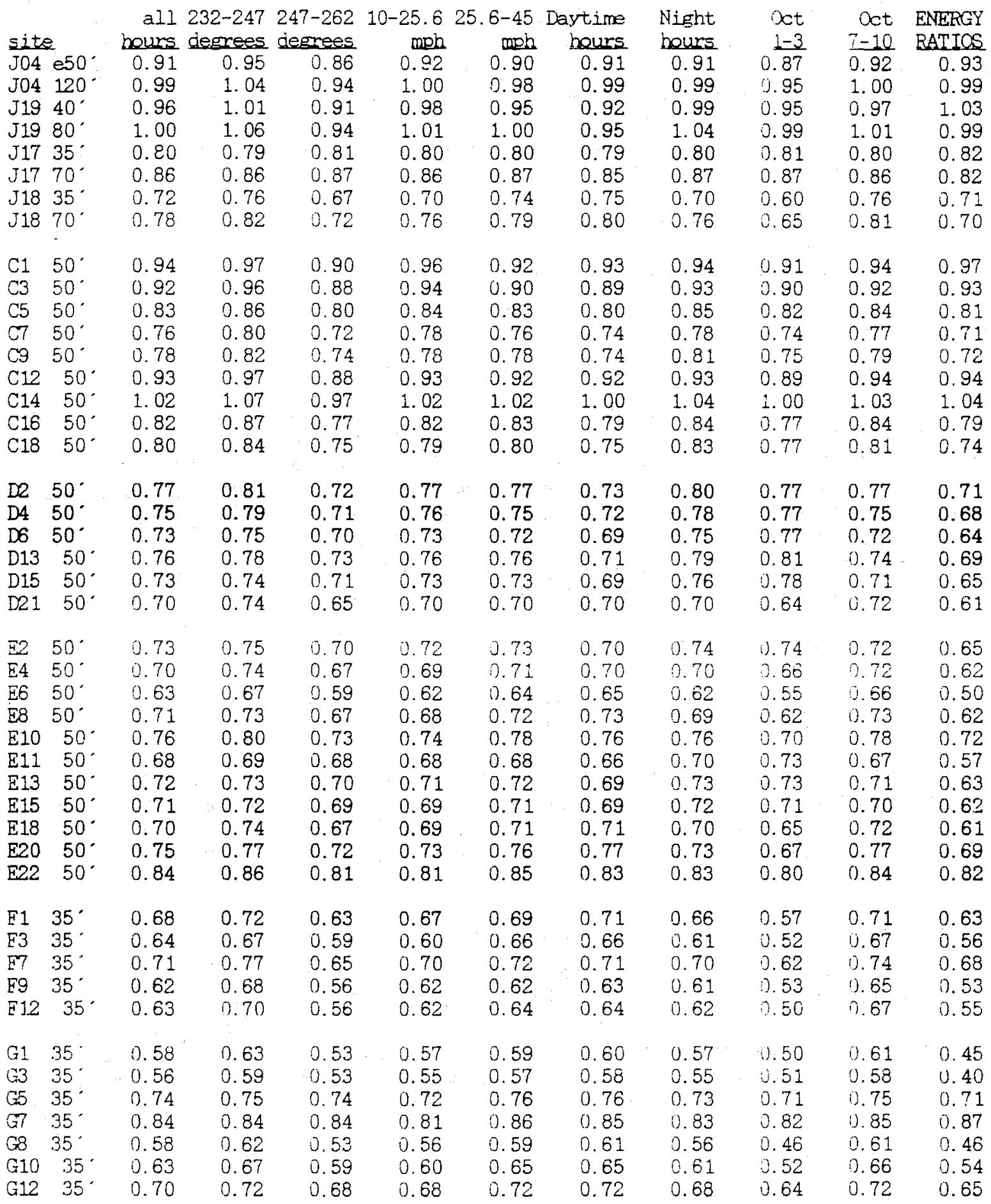


Table 3-10. Jess Ranch Eree-Elow Data Analys is

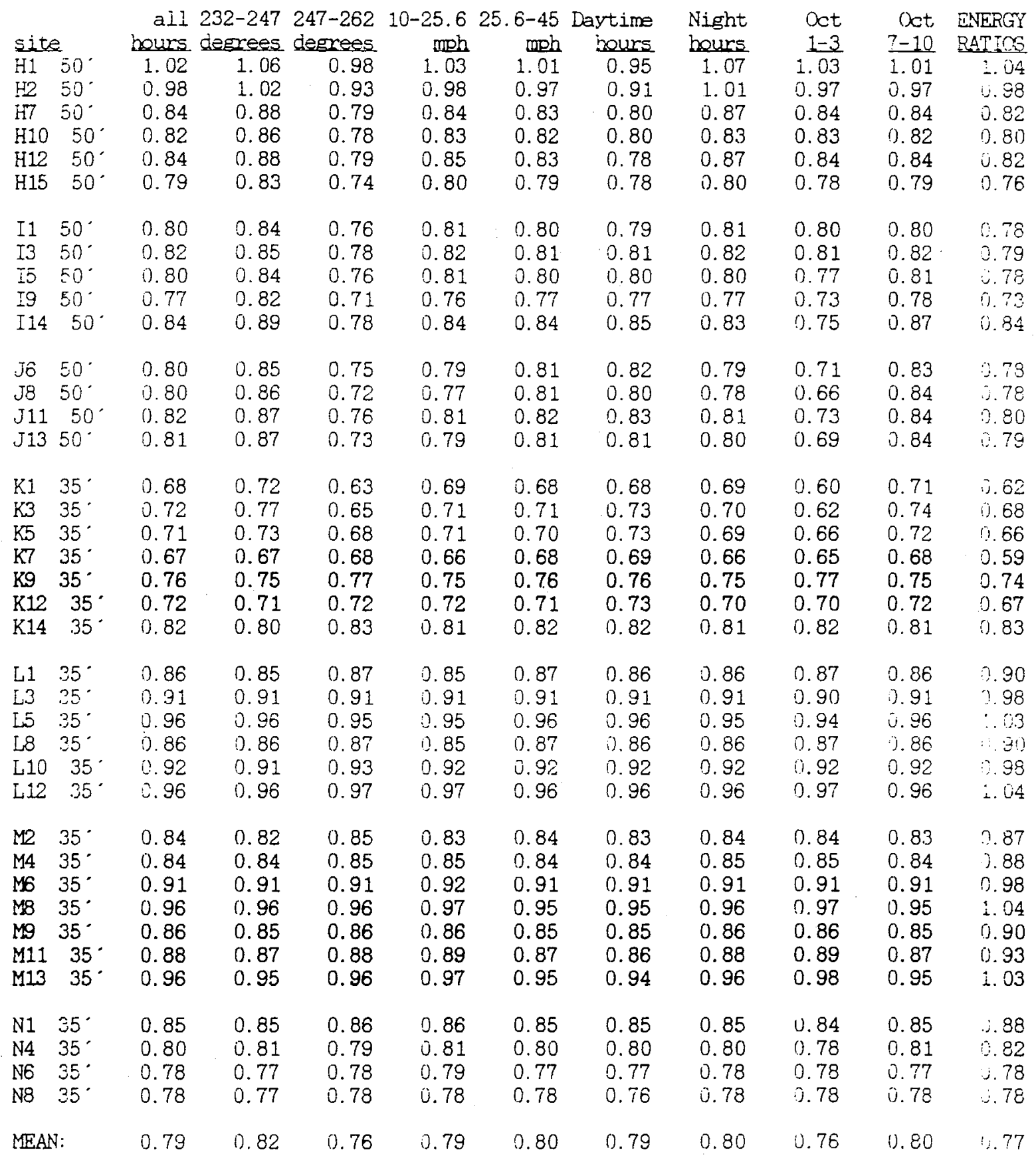




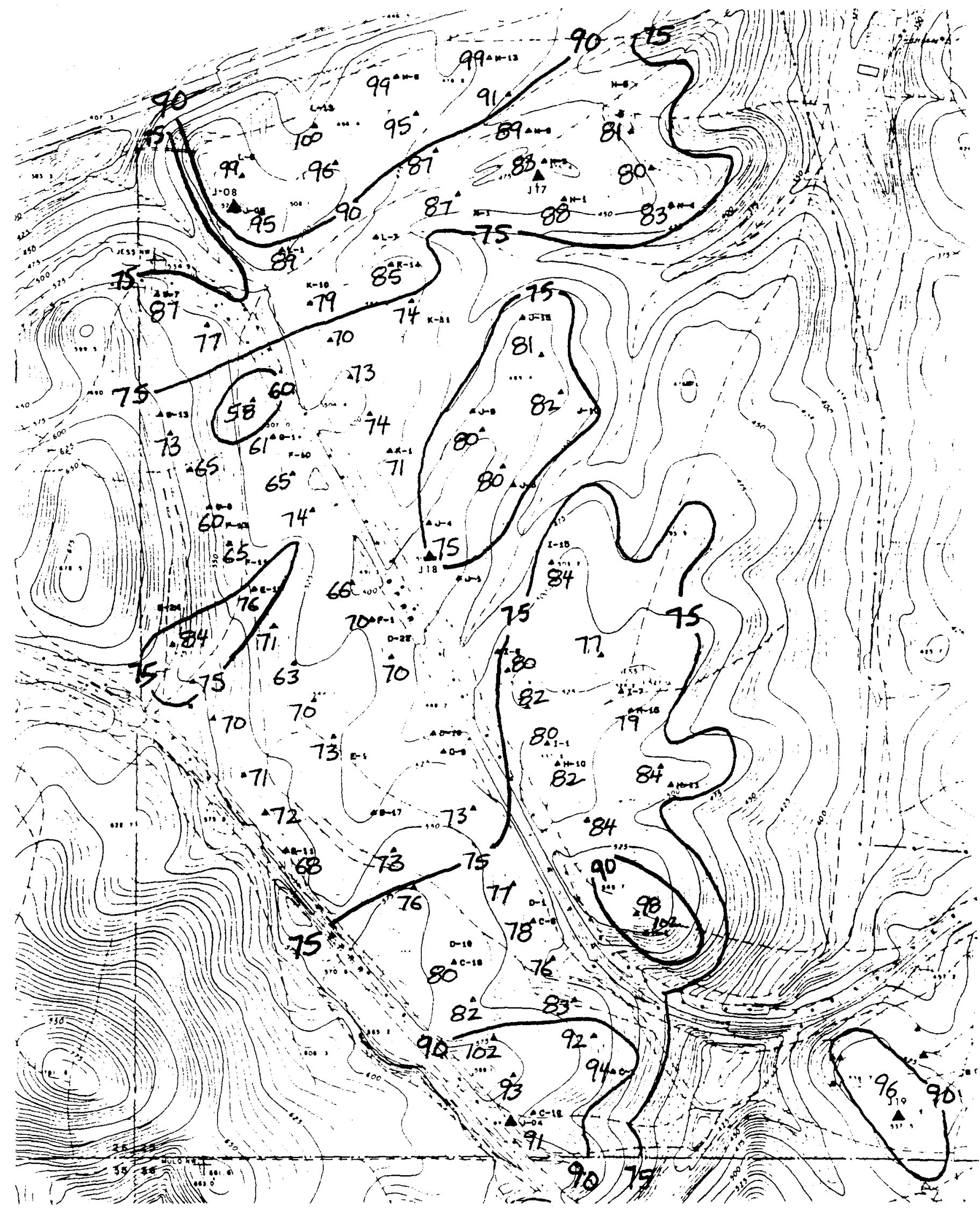

Figure 3-8. Normalized Speed Ratios ( $(Z)$ to J-08 for All Hours 
Note that almost all ratios are less than $100 \%$. This is because of site $\mathrm{J}-08^{\prime} \mathrm{s}$ excellent exposure. J-08 is situated on a bluff, which juts into the large canyon that Interstate 580 runs through. J-08 is exposed to this channel, which is oriented parallel to the west-southwest flow. There are three relatively high wind areas; one around $\mathrm{J}-08$ (extending downwind of $i t$ ), one in the southern part of the study area at $\mathrm{J}-19$, and another in the southern part of the study area (around $\mathrm{H}-1, \mathrm{H}-2, \mathrm{C}-10, \mathrm{C}-12$, and $\mathrm{C}-14$ ). These areas are aligned with the large canyons discussed previously. A fourth, smaller area of relatively high winds can be found near E-10 and E-22. This area is aligned with the third small canyon discussed previously. A relatively low wind-speed area can be found around $\mathrm{G}-1, \mathrm{G}-3$, and $\mathrm{G}-8$. This area appears to be blocked by the 681-ft hill to the immediate southwest. Recall that this is close to the area with low correlation coefficients discussed in section 3.2.2. Limited analysis shows that speed ratios at these low-wind sites increase with increased inversion height. The increase in speed ratios is on the order of $10 \%$ when the inversion top is above $1000 \mathrm{ft}$ MSL.

It is interesting to note that the range of ratios on Jess is considerably larger than that of the ratios on Souza. The Jess study area is larger than Souza, but more homogeneity was expected because of its flatter terrain. Analysis of the inversion data collected on the Souza Ranch, as well as at the Oakland Airport, which is about 30 miles west of the Altamont Pass, shows that the mean inversion height was several hundred feet lower during the Jess free-flow period. Because of the interaction of the terrain with the inversion, the lower inversion heights during the Jess study are believed to be responsible, in part, for the wider range of ratios on the Jess Ranch.

Figure 3-9 is a plot of the energy ratios to J-08. Note that all sites except $\mathrm{J}-08$ have been normalized to hub height (72 ft) using a vertical wind shear exponent of 0.10 . Meteorological towers $\mathrm{J}-17, \mathrm{~J}-18$, and $\mathrm{J}-19$ use their hub-height sensors for this map. Tower J-04 has been adjusted (down) from the 120-ft level. All turbines have been adjusted (up) from the $35-\mathrm{ft}$ or 50-ft levels. Vertical wind shear has been discussed in sections 3.5 and 3.7.1. In Section 3.5, it was shown that sites J-17 and J-18 had shear exponents of about 0.10. These sites have exposure that is representative of many of the sites on Jess. They are in fairly flat areas, not on highly exposed knolls like J-08 and J-19. Using an alpha of 0.10 is a good compromise. Some sites, like turbines $L-3$ and $L-5$, probably have less positive shear because of their similar exposure to J-08. Thus, their theoretical energy production may be biased positively. Other sites, 1 ike G-1, G-3, and G-8, are downwind of a hill and probably have higher shear than 0.10 . Thus, they may be negatively biased. As mentioned in Section 3.7.1, estimating individual sites' vertical shear is difficult, so the reader is cautioned that individual energy ratios on Table 3-10 and Figure 3-9 could be in error by as much as $10 \%$. Figure $3-9$ shows a similar pattern to that of Figure 3-8, except that there is a wider range of ratios (the lows are lower).

Figure $3-10$ is a plot of the normalized (to the 50-ft level) speed ratios to J-08 for wind directions from $232^{\circ}$ to $247^{\circ}$. The pattern is similar to that of Figure 3-8, except that many sites have higher ratios. This is especially true in the southern and central parts of the study area. The ratios in the northern area, around $\mathrm{J}-08$, are unchanged. 


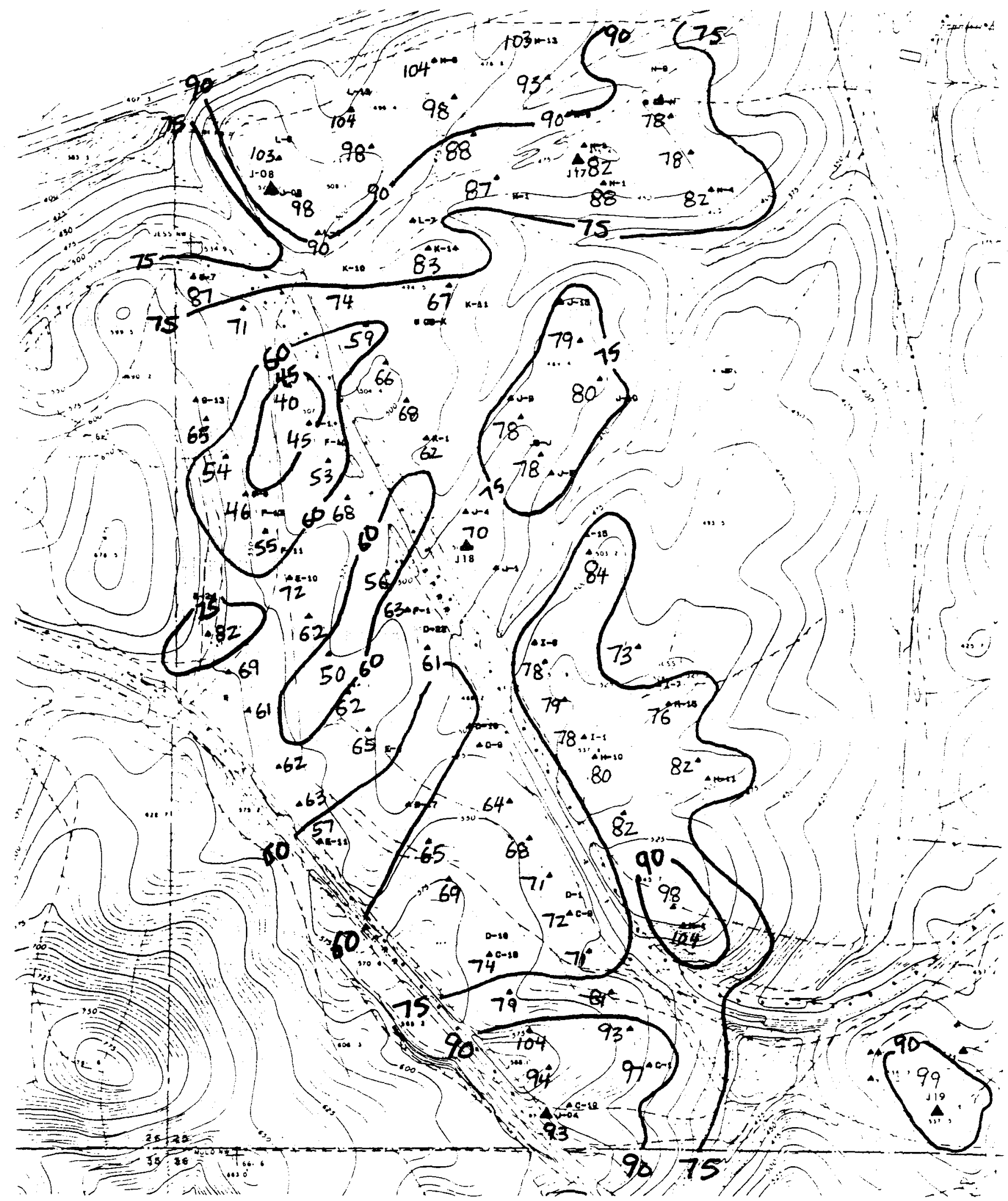

Figure 3-9. Theoretical Energy Ratios (z) to J-08, Nordtank 65 Curve, Assumed Alpha 0.10 


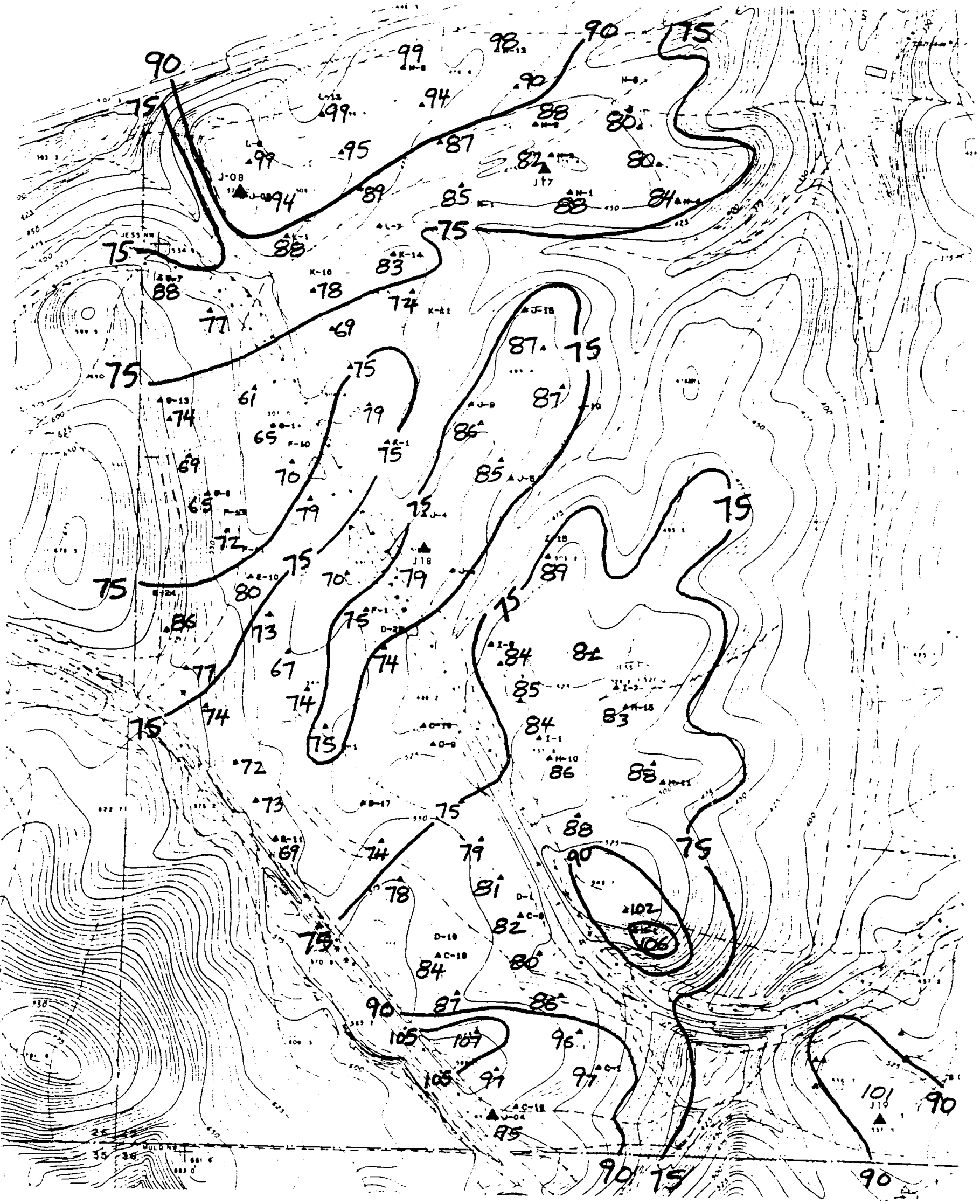

Figure 3-10. Normalized Speed Ratios $(z)$ to J-08 for Wind Direction Band
$232^{\circ}-247^{\circ}$ 
Figure 3-11 is a plot of the normalized speed ratios to J-08 for wind directions from $247^{\circ}$ to $262^{\circ}$. On this figure, many of the ratios are lower than those on Figure 3-8. As in Figure 3-10, the largest swing occurs in the southern and central parts of the study area, with the northern area unchanged. A possible explanation is that in winds with a more southerly component (Figure 3-10) the large canyon near the southern part of the study area (see Figure 2-1) is more aligned with the flow. Thus, these areas get an additional boost and the ratios increase. With more of a westerly component, this canyon is not as well aligned and the ratios fall.

Figure $3-12$ is a plot of the normalized speed ratios to J-08 for the first study period. In this figure, the ratios in the center of the ranch drop considerably. This is especially noticeable around tower J-18 and the F, G, $\mathrm{J}$, and $\mathrm{K}$ turbines. Sites at the northern and southern ends of the study area show little change relative to Figure 3-8. 


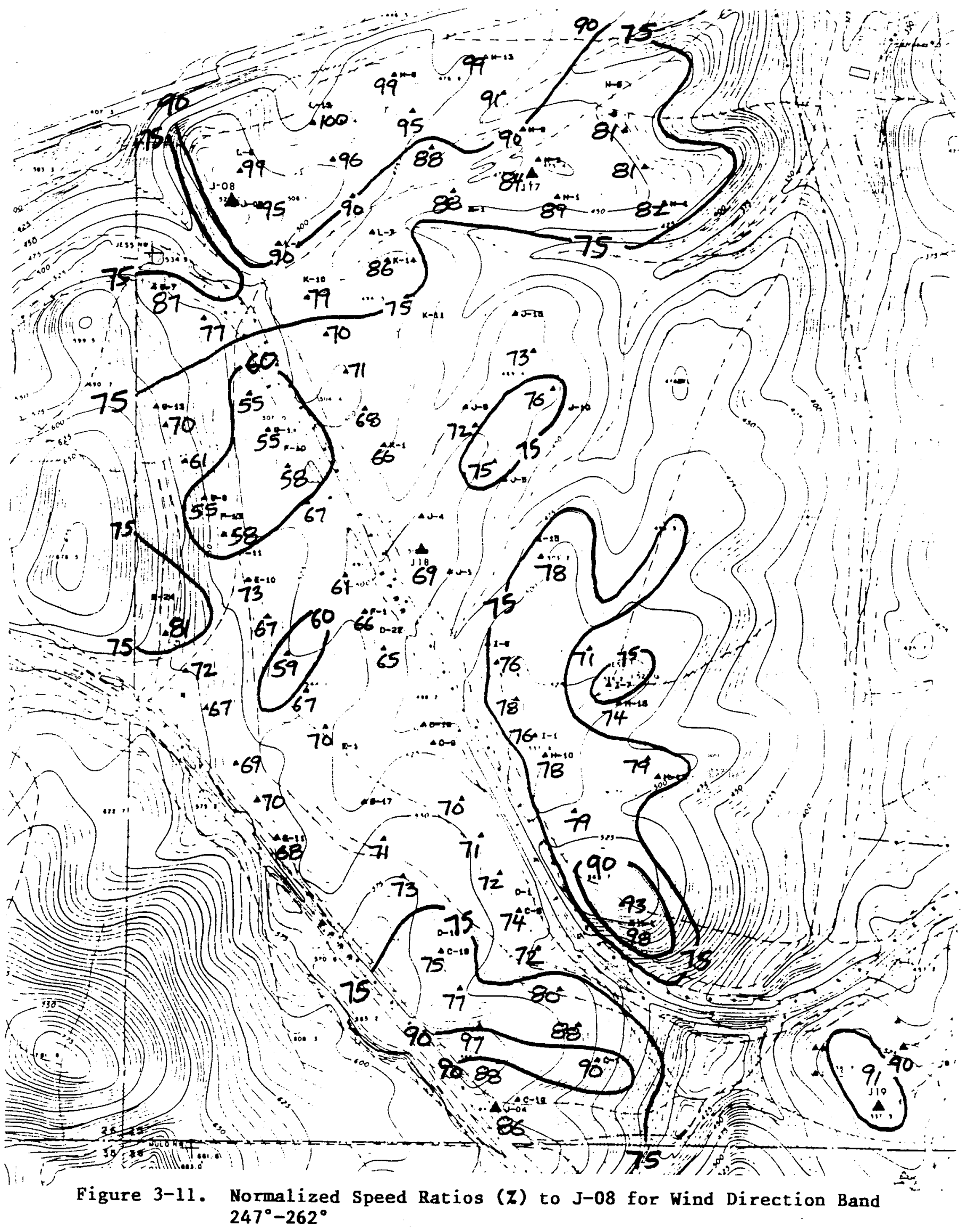




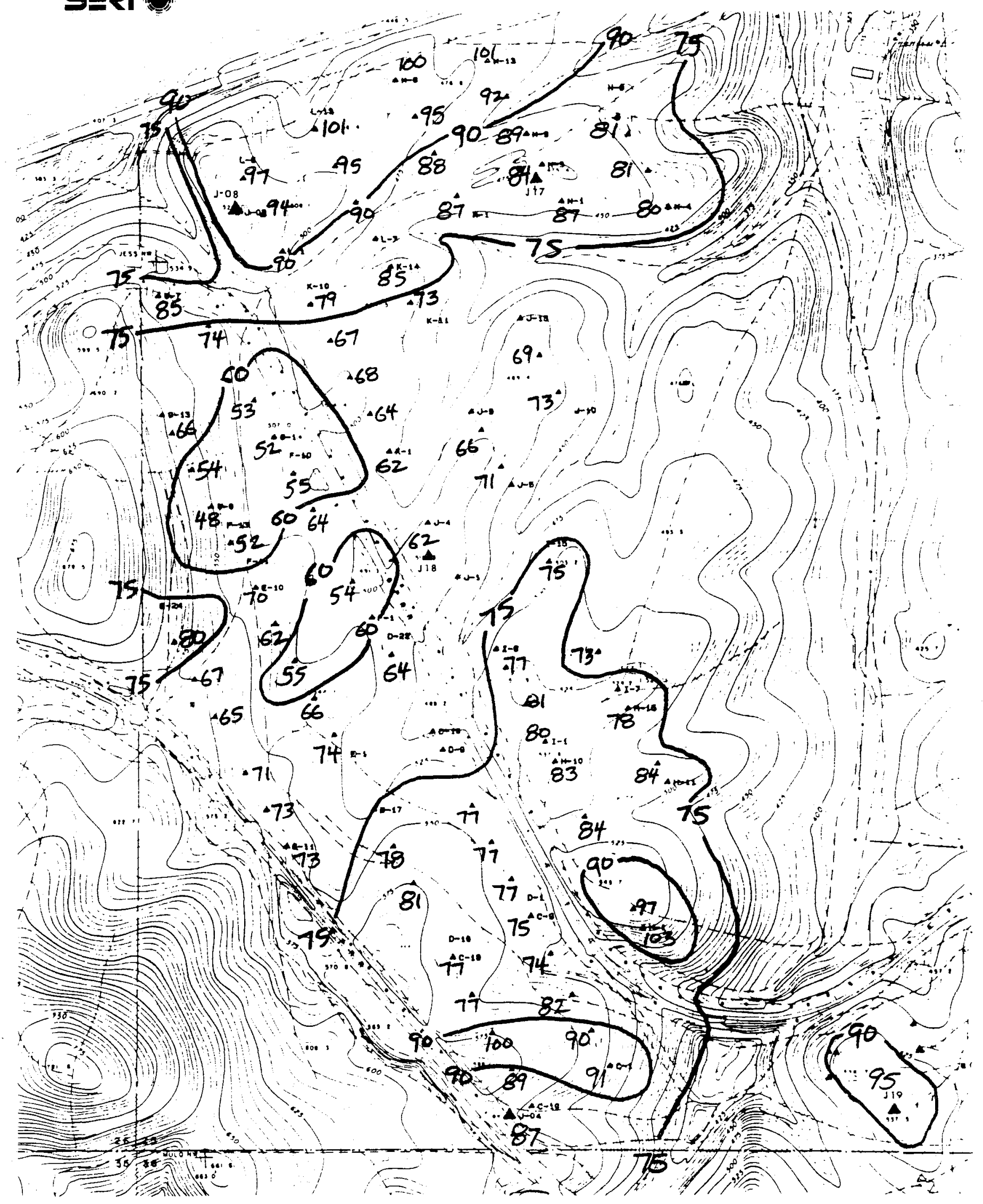

Figure 3-12. Normalized Speed Ratios (z) to J-08 for October 1-3 


\section{CONCLUSIONS}

Wind-speed data were collected from two dense networks on two wind farms in the Altamont Pass. The data were collected during typical spring/summer conditions, with no turbines operating in the study areas. Data were analyzed to determine variability of the wind resource. The principal method for doing this was to calculate wind-speed ratios to a single reference location.

The smaller test area, the Souza Ranch, has moderately complex terrain. The topography slopes gently downward and is punctuated with some small ridge lines that trend perpendicular to the flow. In spite of the complex terrain, the data set revealed a fairly homogeneous resource. All sites were highly correlated to the reference tower, and the mean speed ratio was $98 \%$. The range of speed ratios was $77 \%$ to $111 \%$; however, all but two sites had ratios within a band from $90 \%$ to $110 \%$ of the reference. Site elevation appears to enhance the flow. A topographic pattern at least as significant as the elevation is a combination of ridges and canyons. Specifically, ridges normal to the flow that jut into drainage canyons, parallel to the flow, appear to have the highest wind resource.

The Jess Ranch study area has slightly complex terrain. It slopes gently downward, with a few ridges and valleys oriented parallel to the terrain. The data set was not as homogeneous as the Souza data set. This may be due in part to the lower height of the subsidence inversion during the Jess study period. The average correlation coefficient between the reference site and the other sites was 0.89 . Speed ratios ranged from $56 \%$ to $102 \%$, with a mean ratio of $79 \%$. The range of theoretical energy ratios was $40 \%$ to $104 \%$. Thus, the ratio between the best and worst turbine's theoretical energy production is $260 \%$. These turbines are separated by about a half-mile and an elevation difference of only $60 \mathrm{ft}$. The low speed ratios to J-08 were due to the excellent exposure of the reference site relative to the other sites. Site elevation does not appear to be a factor at this ranch. However, the topographic pattern observed at Souza was seen here as well. Sites on ridges that jut into drainage canyons, or that are downwind of drainage canyons, have the best resource. Conversely, a hill rising $150 \mathrm{ft}$ above the surrounding terrain appears to disturb the flow for a downwind distance of approximately ten times the hill height. The flow disturbance caused by the hill is accentuated by the subsidence inversion. When low inversion heights were measured, the sites downwind of the hill had lower correlation coefficients and lower speed ratios. The strong positive effect of the drainage canyons parallel to the flow may not have universal application. This is true in the Altamont Pass because of the shallow, stable flow under the inversion. In areas with deeper layers or higher instability, these canyons might not have such a dramatic effect. 


\section{APPENDIX A \\ SYNOPTIC METEOROLOGICAL SUMMARIES \\ FOR THE SOUZA AND JESS FREE-FLOW STUDIES}

\section{A.1 Summaries for the Souza Study, September 10-14, 1987}

September 10

On the afternoon of September 10, 1987, at 1600 Pacific Standard Time (PST), the semipermanent, subtropical Pacific surface high-pressure area was centered southwest of San Francisco at $32^{\circ} \mathrm{N} 132^{\circ} \mathrm{W}$, with a central pressure of 1026 millibars (mb). A thermal low-pressure area, also a semipermanent feature, was centered over the southern tip of Nevada, with a central pressure of $1006 \mathrm{mb}$. The axis of this trough extended into southeast British Columbia. (Figure A-1 has the important weather map features labeled.) The surface pressure gradient between the coast and the San Joaquin Valley was moderate at $3 \mathrm{mb}$. Aloft, southwest winds of 10 knots ( $k t)$ and a height of 585 decameters (Dm) were reported at the $500-\mathrm{mb}$ level over Oakland, as the upper winds circulated around a low-pressure area with a central height of $574 \mathrm{Dm}$, located at $40^{\circ} \mathrm{N}$ $134^{\circ} \mathrm{W}$ (see Figure A-2). The height of the marine layer was at a typical summertime level of $400 \mathrm{~m}$. Winds at Souza were $20-30 \mathrm{mph}$ at this time. Although the thermal trough axis was east of its usual position, and extended much farther north than it normally does, this was more or less a typical summertime weather pattern over the western United States.

\section{September 11}

At 0400 PST on September 11 , surface high pressure was centered at $33^{\circ} \mathrm{N} 137^{\circ} \mathrm{W}$, with a central pressure of $1025 \mathrm{mb}$. The thermal low was centered over southwest Arizona, with a central pressure of $1005 \mathrm{mb}$, and the axis continued east of its normal position and extended through Nevada, Oregon, and into eastern Washington (see Figure A-3). The surface pressure gradient from the coast to the valley at this time had diminished to $2.0-2.5 \mathrm{mb}$. The $500-\mathrm{mb}$ low moved eastward to $40^{\circ} \mathrm{N} 130^{\circ} \mathrm{W}$. At 0 akland, the wind at $500 \mathrm{mb}$ had increased to $15 \mathrm{kt}$ out of the southwest, and the height of the $500 \mathrm{mb}$ surface had dropped $5 \mathrm{Dm}$ (which is greater than the fall that normally occurs during that part of the day) to $580 \mathrm{Dm}$ (see Figure A-4). The marine layer at this time continued at a depth of about $400 \mathrm{~m}$. Winds at Souza had increased slightly to $25-30 \mathrm{mph}$.

At 1600 PST, the thermal low center had deepened to $1002 \mathrm{mb}$ and moved into southeastern California, with the trough axis extending into eastern Washington. Along this axis, there was another low center of $1005 \mathrm{mb}$ in central Nevada, and one of $1007 \mathrm{mb}$ in northeast Oregon (see Figure A-5). These last two centers were probably due more to atmospheric dynamics rather than surface heating. The surface pressure gradient had increased to $3.0-3.5 \mathrm{mb}$. At $500 \mathrm{mb}$, the upper level low moved southeast toward the area and intensified slightly to $573 \mathrm{Dm}$ at $38^{\circ} \mathrm{N} 128^{\circ} \mathrm{W}$ (see Figure A-6). This caused the winds at this level to back down to the south and increase to $20 \mathrm{kt}$ above Oakland, and the level of the 500-mb surface dropped to $577 \mathrm{Dm}$ at a time of day when it normally rises. It also allowed the marine layer to deepen to $800 \mathrm{~m}$. The winds at Souza had increased to $25-35 \mathrm{mph}$ in a weather pattern that is quite common in spring but occurs infrequently in the summertime. 


\section{September 12}

At 0400 PST on September 12, the Pacific high-pressure area was centered at $35^{\circ} \mathrm{N} 150^{\circ} \mathrm{W}$. The thermal low had a central pressure of $1003 \mathrm{mb}$ and was centered over southern Nevada; the axis extended southward into extreme northwestern Mexico and northward into eastern Oregon (see Figure A-7). The surface pressure gradient had slackened to about $2 \mathrm{mb}$. The $500-\mathrm{mb}$ low continued its southeast trek to a position at $35^{\circ} \mathrm{N} 125^{\circ} \mathrm{W}$, and the central pressure dropped to $570 \mathrm{Dm}$. At Oakland, the $500-\mathrm{mb}$ winds became southeast and diminished to $5 \mathrm{kt}$, while the level of the 500-mb surface fell to 573 Dm (see Figure A-8). The marine layer was somewhat shallower, at $650 \mathrm{~m}$. As the pressure gradient had diminished and the marine layer had become thinner, the winds at Souza had decreased to about $25 \mathrm{mph}$.

At 1600 PST, the Pacific high-pressure area had a central pressure of $1025 \mathrm{mb}$ and was located at $34^{\circ} \mathrm{N} 143^{\circ} \mathrm{W}$. The thermal low was centered over southeastern California, with a central pressure of $1002 \mathrm{mb}$; a trough axis extended into the southern Sierra Nevada. A dynamic low-pressure center of 1000 mb was located in northwestern Nevada, and a secondary center of 1002 mb was centered over western Idaho (see Figure A-9). The pressure difference from the coast to the valley had increased to $3 \mathrm{mb}$. Aloft, the 500-mb disturbance intensified to $569 \mathrm{Dm}$ and moved to a position just off the California coast at Point Conception. In response, the winds at that level became east-northeast above Oakland (see Figure A-10). The marine layer continued at about the same depth at $700 \mathrm{~m}$. The winds at the site also changed 1 ittle, at $25-35 \mathrm{mph}$, in a West Coast weather pattern that is typical in the spring but quite unusual in the summertime.

\section{September 13}

On September 13, at $0400 \mathrm{PST}$, surface high pressure was centered at $32^{\circ} \mathrm{N}$ $141^{\circ} \mathrm{W}$, with a central pressure of $1025 \mathrm{mb}$. The thermal low-pressure system was gone, and dynamic low-pressure centers of $1004 \mathrm{mb}$ and 1003 mb were located over southern Nevada and southwestern Idaho, respectively (see Figure A-I1). The surface pressure gradient between the coast and the valley was about $2 \mathrm{mb}$. Aloft, the upper low moved into southern California; winds above Oakland were from the northeast at $10 \mathrm{kt}$, with the $500-\mathrm{mb}$ surface measured at $574 \mathrm{Dm}$ (see Figure A-12). With cyclonic curvature aloft, the layer of marine air deepened to $950 \mathrm{~m}$. At Souza, the winds had diminished to about $20-25 \mathrm{mph}$.

At 1600 PST, surface high pressure continued well offshore. The low-pressure center that had been over southern Nevada at 0400 PST was now centered over southern Arizona with a central pressure of $1009 \mathrm{mb}$. The low over southwestern Idaho continued to be nearly stationary with a central pressure of $1003 \mathrm{mb}$ (see Figure A-13). The surface gradient between San Francisco and Sacramento had increased to $2.7 \mathrm{mb}$. At the $500-\mathrm{mb}$ level, the upper low had moved into southern Nevada, and at Oakland, the 500-mb height had risen to $581 \mathrm{Dm}$, with the winds becoming north-northwest at $15 \mathrm{kt}$. These winds were in response to the movement of the upper level low out of the area and the upstream ridge moving in behind it (see Figure A-14). With the upper air flow becoming anticyclonic, and the marine layer becoming shallower at $600 \mathrm{~m}$, the winds at Souza decreased to 10-20 mph in the "spring-like" weather pattern. 


\section{September 14}

At 0400 PST on September 14, high pressure at the surface was centered at $42^{\circ} \mathrm{N}$ $154^{\circ} \mathrm{W}$, with a weak ridge extending into northern California and Oregon. Once again, the thermal trough was absent; but the dynamic low pressure center over southwestern Idaho continued, though weakening, with a central pressure of $1010 \mathrm{mb}$ (see Figure A-15). The surface gradient between the coast and the Central valley had diminished to $1.0-1.5 \mathrm{mb}$. The upper low was over southeastern Utah at this time, and the ridge that had been upstream $12 \mathrm{~h}$ earlier had just passed Oakland. Heights continued to rise at Oakland, as the 500-mb surface was measured at $583 \mathrm{Dm}$ and the upper winds at Oakland were out of the northwest at $15 \mathrm{kt}$ (see Figure A-16). The marine layer had deepened a little to a depth of $750 \mathrm{~m}$. The winds at Souza increased slightly to 15-25 mph.

At $1600 \mathrm{PST}$, the surface high-pressure area was centered at $42^{\circ} \mathrm{N} 150^{\circ} \mathrm{W}$, and a surface cold front extended from southeastern British Columbia through eastern Washington and Oregon and northwestern California. The thermal low had reformed over southern California, with a central pressure of $1010 \mathrm{mb}$ (see Figure $\mathrm{A}-17$ ). The surface gradient had increased to $2.0-2.5 \mathrm{mb}$. At $500 \mathrm{mb}$, heights continued to rise at Oakland to $587 \mathrm{Dm}$, and the upper winds were westnorthwest at $20 \mathrm{kt}$ (see Figure A-18). The marine layer quickly became very shallow, with the base of the inversion reported at the surface at Oakland. The winds at Souza at 1300 PST, when the study ended, were 15-20 mph. Although the weather was in the process of returning to normal summertime conditions, it was still in a springtime weather pattern.

\section{A.2 Summaries for the Jess Study, October 1-3 and October 7-10, 1987}

\section{October 1}

On the afternoon of October 1,1987 at 1600 PST, the semipermanent, subtropical Pacific surface high-pressure area was centered southwest of San Erancisco at $29^{\circ} \mathrm{N} 130^{\circ} \mathrm{W}$, with a central pressure of $1019 \mathrm{mb}$. A thermal low-pressure area of $1008 \mathrm{mb}$ was centered over the Imperial Valley, with a trough axis extending northward over the Central Valley, through western Oregon, and into western Washington (see Figure A-19). The surface pressure gradient between the California coast and the Central Valley at this time was rather large at $4 \mathrm{mb}$. Aloft, south-southeast winds of $15 \mathrm{kt}$, with a $500-\mathrm{mb}$ height of $586 \mathrm{Dm}$, were reported at 0akland. The winds were the result of the circulation around an upper level high-pressure area with a central pressure of $588 \mathrm{Dm}$, located over southern Idaho (see Figure A-20). Because of the anticyclonic motion and high heights aloft, the layer of marine air was shallow at $300 \mathrm{~m}$. Although the surface pressure gradient was quite large, the winds at Jess Ranch were only 20-25 mph because of the influence of the shallow marine layer in this typical summertime weather pattern.

\section{October 2}

At 0400 PST on October 2, surface high pressure developed a center of $1022 \mathrm{mb}$ at $41^{\circ} \mathrm{N} 128^{\circ} \mathrm{W}$ and was starting to build inland over the Pacific Northwest behind a weak, diffuse, cold front. The thermal low had a central pressure of $1011 \mathrm{mb}$ and was located over the east coast of Baja California, with the trough axis extending northward through the San Joaquin Valley into the Sacramento Valley (see Figure A-21). The surface pressure gradient was still large 
at $2.5-3.0 \mathrm{mb}$. At the $500-\mathrm{mb}$ level, heights continued to be high at Oakland, with $585 \mathrm{Dm}$ reported. The wind at that level was out of the southwest at $5 \mathrm{kt}$ in the circulation around a strong upper level low-pressure area that was centered in the Gulf of Alaska (see Figure A-22). As a result, the marine layer deepened to $500 \mathrm{~m}$. With the pressure gradient weakening and surface high pressure building into the Pacific Northwest, the winds at Jess had diminished to 15-25 mph and would continue to decline and even become northerly during the day.

At $1600 \mathrm{PST}$, surface high pressure was centered at $37^{\circ} \mathrm{N} 133^{\circ} \mathrm{W}$, with a central pressure of $1026 \mathrm{mb}$ and a weak ridge extending into the Pacific Northwest. The thermal low was centered over extreme northwestern Mexico, with a central pressure of $1010 \mathrm{mb}$, and the trough axis extended northward through southern California, the Central Valley, Oregon, and eastern Washington (see Figure A-23). The pressure gradient was a moderate $2.4 \mathrm{mb}$. Aloft, Oakland was sandwiched between high-pressure centers of $589 \mathrm{Dm}$ at $\left(36^{\circ} \mathrm{N} 132^{\circ} \mathrm{W}\right)$ and $591 \mathrm{Dm}$ over Utah. The level of the $500 \mathrm{mb}$ surface at Oakland had risen to $589 \mathrm{Dm}$, greater than the normal daytime rise (see Figure A-24). Winds over Oakland were 1 ight and variable, and the marine layer became quite shallow at $100 \mathrm{~m}$ under the influence of the strong high pressure aloft. At Jess, the winds that had become light northerly earlier in the day continued out of that direction, and they would not become southwest again until 1700 PST in the typical summertime weather pattern.

\section{October 3}

At 0400 PST on October 3, the Pacific high was centered at $38^{\circ} \mathrm{N} 135^{\circ} \mathrm{W}$, with a central pressure of $1030 \mathrm{mb}$ and a weak ridge extending over Washington and Oregon. The thermal low was centered in northern Baja California; the trough extended northward off the southern California coast to Point Conception, then inland over the coast range through the Sacramento Valley (see Figure A-25). The pressure gradient between the central California coast and the Central Valley had slackened to $1.7 \mathrm{mb}$ at this time. At $500 \mathrm{mb}$, high pressure was centered at $38^{\circ} \mathrm{N} 129^{\circ} \mathrm{W}$, with a center of $592 \mathrm{Dm}$ (see Figure A-26). In response to the movement of the upper high toward the coast, the winds above Oakland had become northerly at $10 \mathrm{kt}$ and the heights continued to rise to $590 \mathrm{Dm}$. The marine layer was very shallow at this time, less than $100 \mathrm{~m}$. The winds at Jess that had been about $15 \mathrm{mph}$ at 0300 had stopped completely at this time, and the study ended. The winds would later become northerly in a pattern that was developing the characteristics of a classic late summer/early fall coastal heat wave.

\section{October 7}

On the morning of October 7 at 0400 PST, the semipermanent, subtropical eastern Pacific surface high-pressure area was centered southwest of San Francisco at $27^{\circ} \mathrm{N} 130^{\circ} \mathrm{W}$, with a central pressure of $1020 \mathrm{mb}$. The thermal low-pressure area was located over the Mexico/Arizona border and had a central pressure of $1008 \mathrm{mb}$, with a weak trough axis extending northwestward along the southern Sierra Nevada (see Figure A-27). The surface pressure gradient between the California coast and the Central Valley at this time was large at $3.5 \mathrm{mb}$. Aloft, a weak trough just offshore was spinning out of a deep upper level lowpressure area centered at $38^{\circ} \mathrm{N} 145^{\circ} \mathrm{W}$ with a central pressure of $551 \mathrm{Dm}$. This caused west-southwest winds of $20 \mathrm{kt}$, with a height of $581 \mathrm{Dm}$ at the $500 \mathrm{mb}$ 
level, over Oakland (see Figure A-28). Because of the approaching upper level trough and the west-southwest winds aloft, the summertime layer of marine air was a little deeper than usual at $500 \mathrm{~m}$. With an ample marine layer and a strong pressure gradient, the winds at the Jess Ranch were quite high at 30$35 \mathrm{mph}$.

At 1600 PST, the Pacific high had moved toward California and was centered at $30^{\circ} \mathrm{N} 127^{\circ} \mathrm{W}$, with a central pressure of $1021 \mathrm{mb}$. The thermal low was nearly unchanged, with a weak trough over the southern Sierra Nevada (see Figure A-29). The surface pressure gradient between the coast and the San Joaquin Valley continued at about $3.5 \mathrm{mb}$. At the $500-\mathrm{mb}$ level, the weak trough that was offshore at 0400 was now over the Sierra, while the upper low had filled to $561 \mathrm{Dm}$ and was now located at $39^{\circ} \mathrm{N} 141^{\circ} \mathrm{W}$ (see Figure A-30). In response, the winds at 0akland had become west-northwest at $20 \mathrm{kt}$, and the height of the $500-\mathrm{mb}$ surface had risen to $583 \mathrm{Dm}$. The depth of the marine layer continued at $500 \mathrm{~m}$. The winds at Jess Ranch had decreased to 25-30 mph in the typical summertime weather pattern.

\section{October 8}

At 0400 PST on October 8, surface high pressure was centered at $26^{\circ} \mathrm{N} 130^{\circ} \mathrm{W}$, with a central pressure of $1019 \mathrm{mb}$. The thermal low was centered over southwest Arizona, with a central pressure of $1008 \mathrm{mb}$, and the axis was oriented along the southern Sierra Nevada, through the Sacramento Valley, and through northwestern California (see Figure A-31). The surface pressure gradient from the coast to the valley at this time was a moderate $2.0-2.5 \mathrm{mb}$. The $500-\mathrm{mb}$ low moved eastward slightly to $39^{\circ} \mathrm{N} 140^{\circ} \mathrm{W}$, with a central pressure of $560 \mathrm{Dm}$. At Oakland, the wind at $500 \mathrm{mb}$ was out of the west-northwest at $15 \mathrm{kt}$, and the height of the $500-\mathrm{mb}$ surface remained $583 \mathrm{Dm}$ in response to a weak upstream ridge just offshore (see Figure A-32). The marine layer deepened slightly to $700 \mathrm{~m}$. The winds at Jess were about $25 \mathrm{mph}$.

At $1600 \mathrm{PST}$, the thermal low center had deepened to $1006 \mathrm{mb}$ and moved into southeastern California, with the trough axis along the Sierra Nevada (see Figure A-33). The surface pressure gradient had increased rapidly to over $3.5 \mathrm{mb}$. At $500 \mathrm{mb}$, the upper level low moved to $38^{\circ} \mathrm{N} 136^{\circ} \mathrm{W}$, with a central pressure of $566 \mathrm{Dm}$. The axis of the weak ridge that had been offshore at 0400 had just passed Oakland and was now approaching the Sierra, causing the upper winds at Oakland to back to the southwest at $10 \mathrm{kt}$ (see Figure A-34). The winds at Jess continued at $25 \mathrm{mph}$ in the typical summertime weather pattern.

\section{October 9}

At 0400 PST on October 9, the Pacific high-pressure area was centered at $25^{\circ} \mathrm{N}$ $133^{\circ} \mathrm{W}$. The thermal low had a central pressure of $1008 \mathrm{mb}$ and was centered over the California-Arizona border, with the axis extending northward along the west side of the Central Valley, into northwestern California, and along the Oregon coast. A dynamic surface low (a reflection of the low in the upper atmosphere) with a central pressure of $1010 \mathrm{mb}$ was centered at $36^{\circ} \mathrm{N} 135^{\circ} \mathrm{W}$ (see Figure A-35). The surface pressure gradient had slackened to $2.0-2.5 \mathrm{mb}$. The $500-\mathrm{mb}$ low continued its slow eastward trek to a position at $37^{\circ} \mathrm{N} 135^{\circ} \mathrm{W}$, with a central pressure of $565 \mathrm{Dm}$. At Oakland, the 500-mb winds continued out of the southwest and increased to $20 \mathrm{kt}$ while the level of the 500-mb surface fell to $578 \mathrm{Dm}$ (see Figure A-36). The marine layer was deep at $700 \mathrm{~m}$. As the 
pressure gradient had diminished, the winds at Jess had decreased slightly to $20 \mathrm{mph}$.

At 1600 PST, the Pacific high was ill defined while the thermal low was centered over southeastern California, with a central pressure of $1008 \mathrm{mb}$, and the trough axis extended northward along the Sierra Nevada. A dynamic lowpressure area was centered over the Pacific at $34^{\circ} \mathrm{N} 132^{\circ} \mathrm{W}$, with a central pressure of $1010 \mathrm{mb}$ (see Figure A-37). The pressure difference from the coast to the valley had increased to $2.5-3.0 \mathrm{mb}$. Aloft, the 500-mb low-pressure area was now situated at $34^{\circ} \mathrm{N} 132^{\circ} \mathrm{W}$, directly above the surface low, with a central pressure of $567 \mathrm{Dm}$. In response, the winds at that level became southerly at $25 \mathrm{kt}$ above 0 akland (see Figure A-38). The marine layer was somewhat shallower, at a depth of $550 \mathrm{~m}$. The winds at Jess increased slightly to $25 \mathrm{mph}$ in a West Coast weather pattern that is typical in the spring but occurs infrequently in the summertime.

October 10

On October 10 at $0400 \mathrm{PST}$, surface high pressure was centered at $30^{\circ} \mathrm{N} 122^{\circ} \mathrm{W}$, with a central pressure of $1017 \mathrm{mb}$. Surface 1 ow pressure was centered at $34^{\circ} \mathrm{N}$ $131^{\circ} \mathrm{W}$ with a central pressure of $1010 \mathrm{mb}$. The thermal low was centered near Yuma, Ariz., with a central pressure of $1012 \mathrm{mb}$. The thermal trough axis extended out of the low, up the southern Sierra Nevada, through the Sacramento Valley, and into the California-Oregon border region (see Figure A-39). The surface pressure gradient between the coast and the valley had decreased significantly to about $1.5 \mathrm{mb}$. Aloft, the upper low was directly above the surface low at $34^{\circ} \mathrm{N} 131^{\circ} \mathrm{W}$, and Oakland had south-southeast winds of $30 \mathrm{kt}$ at $500 \mathrm{mb}$, with a height of $578 \mathrm{Dm}$ reported (see Figure A-40). With cyclonic curvature aloft, the layer of marine air deepened to $750 \mathrm{~m}$. At Jess, the winds had diminished slightly to about 15-20 mph in the "spring-like" weather pattern. 


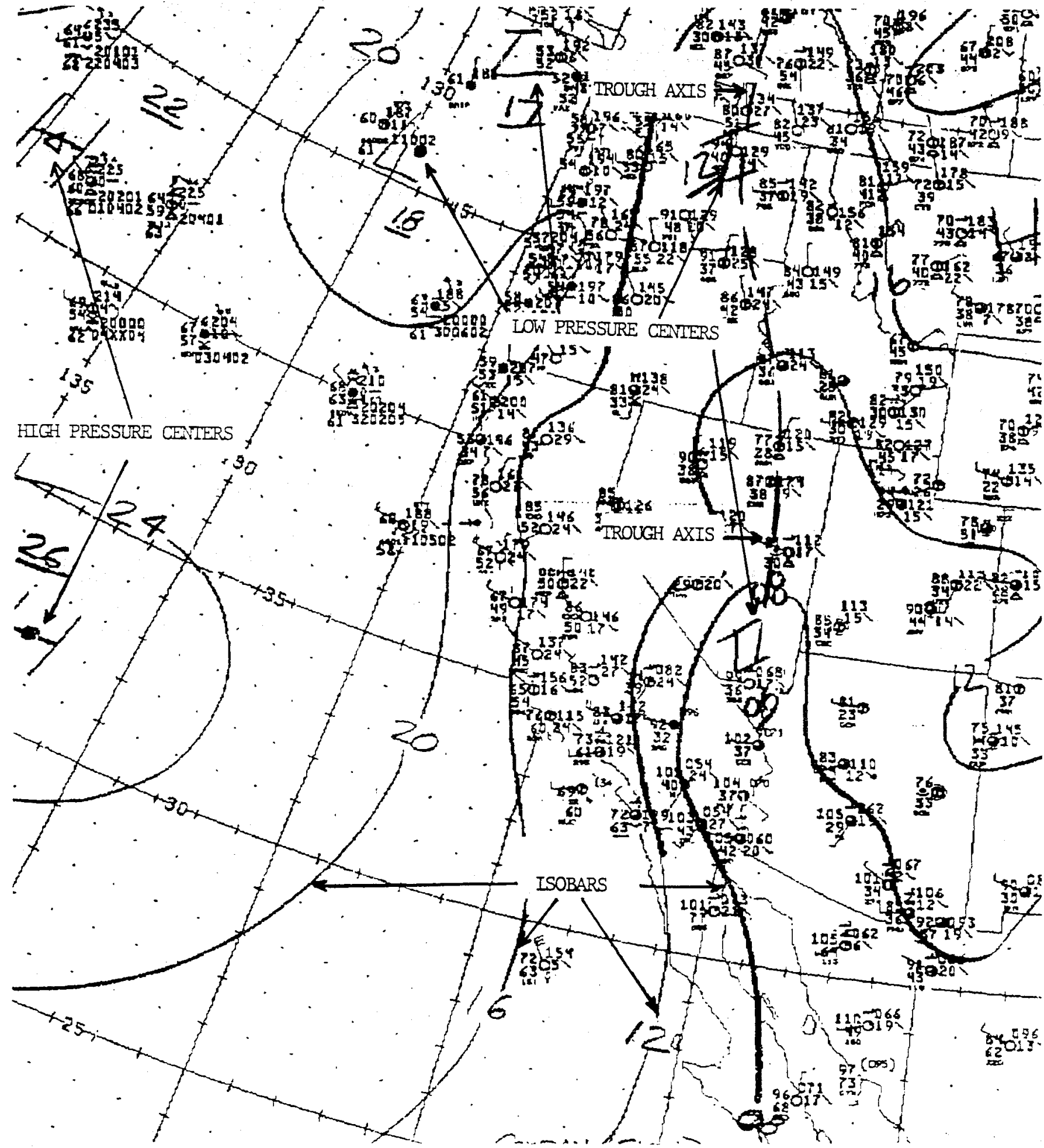

Figure A-1. Surface Weather Map for September 19, 1600 PST 


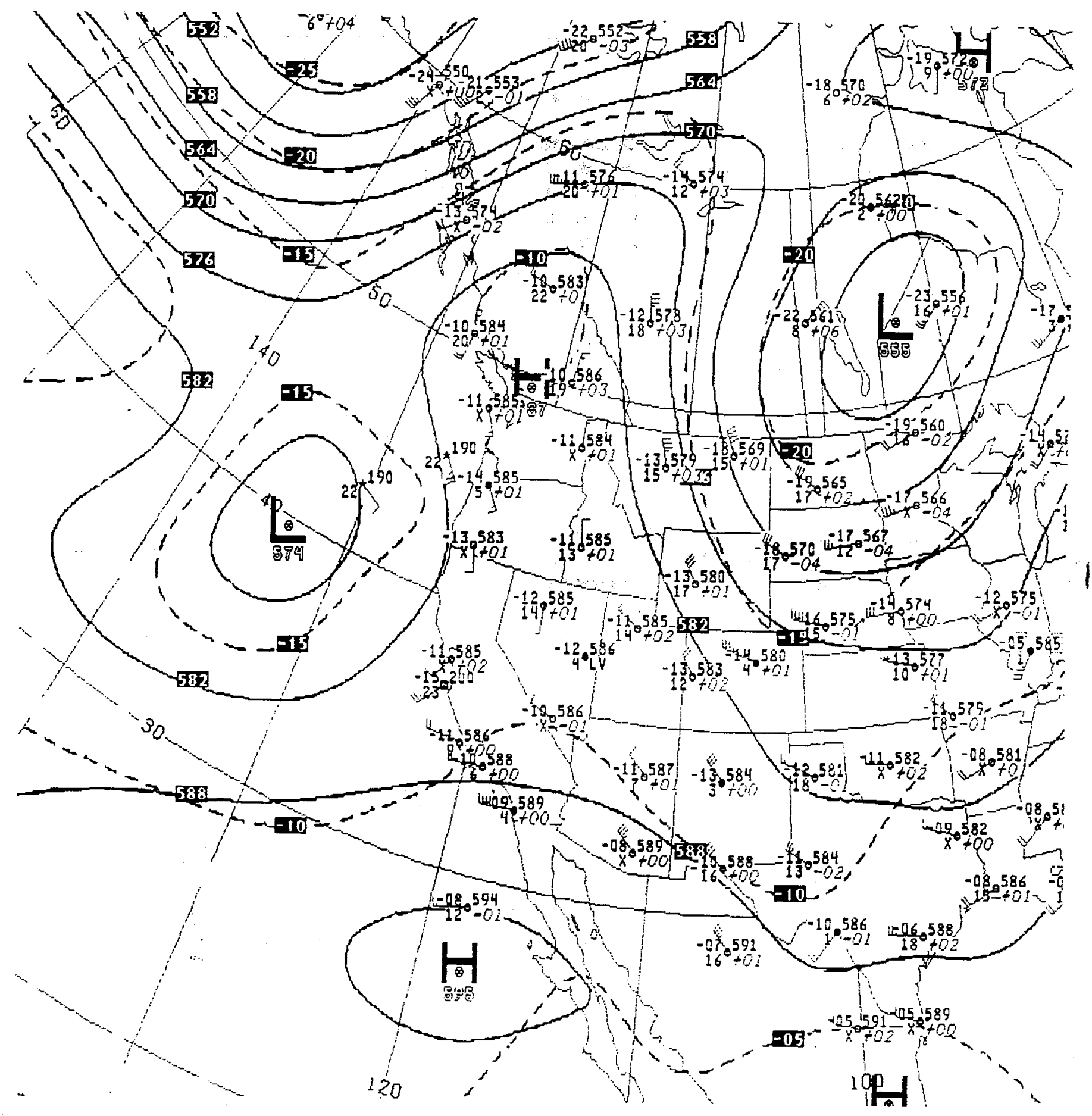

Figure A-2. 500-mb Map for September 10, 1600 PST 


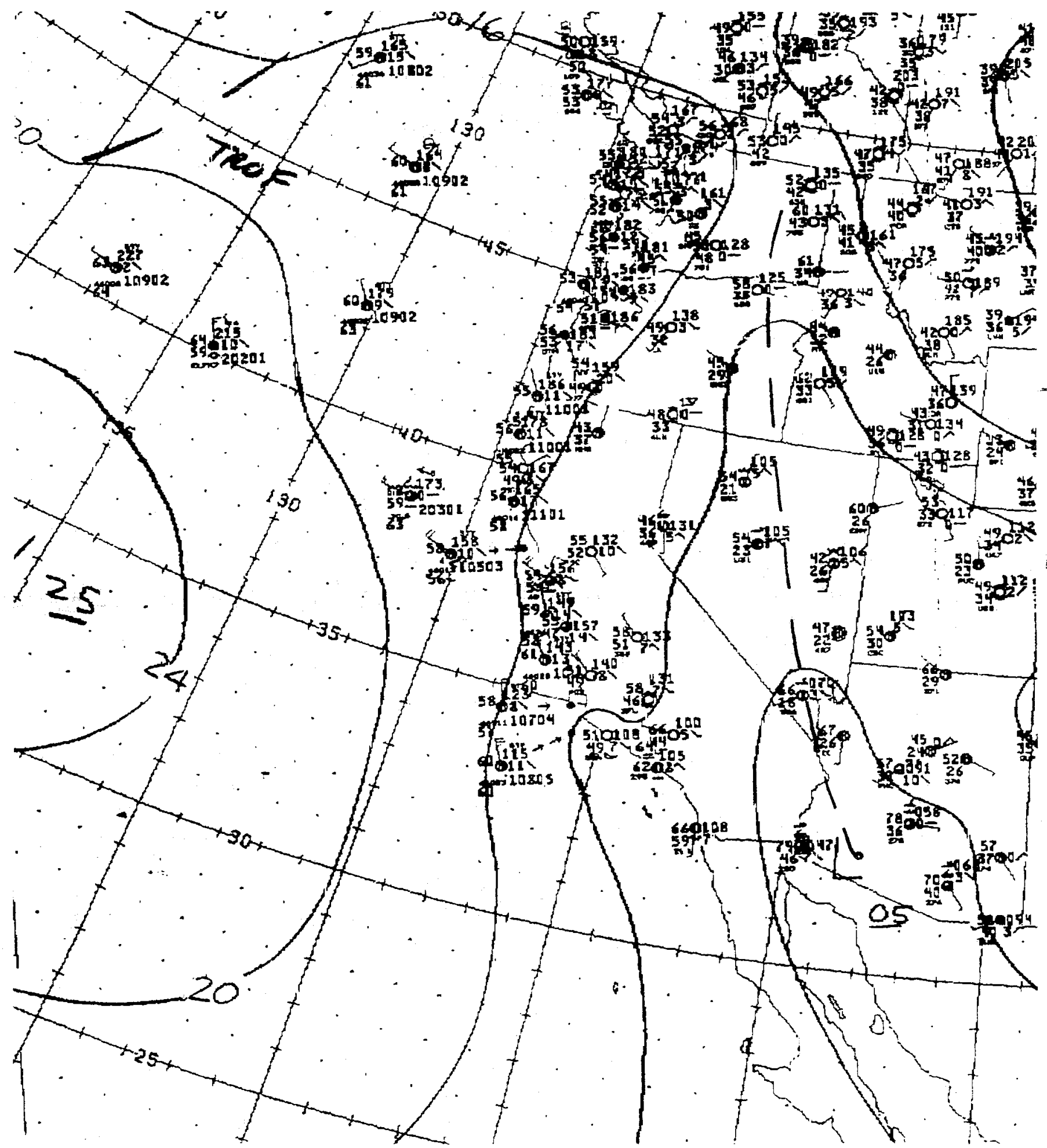

Figure A-3. Surface Weather Map for September 11, 0400 PST 


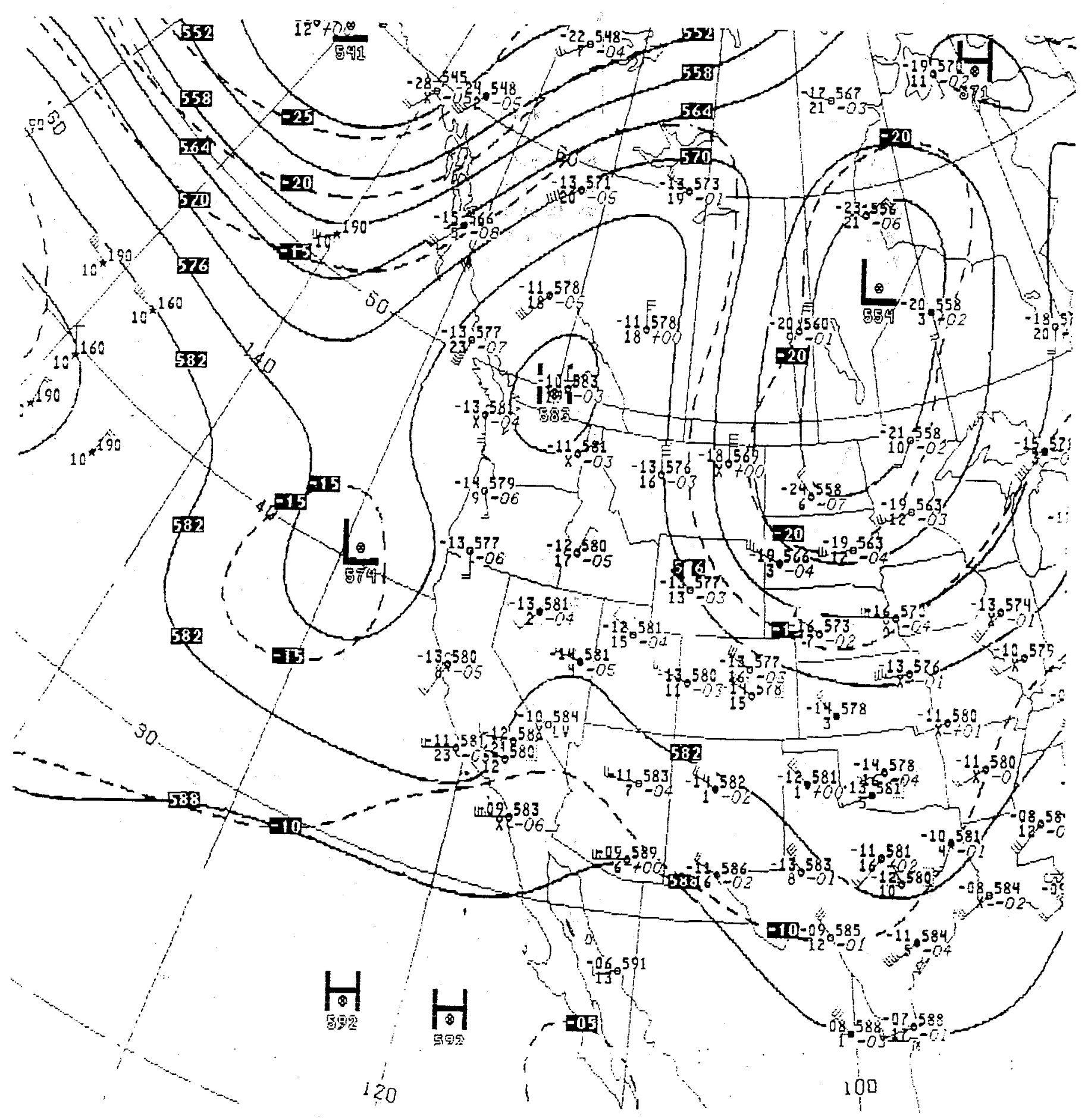

Figure A-4. 500-mb Map for September 11, 0400 PST 


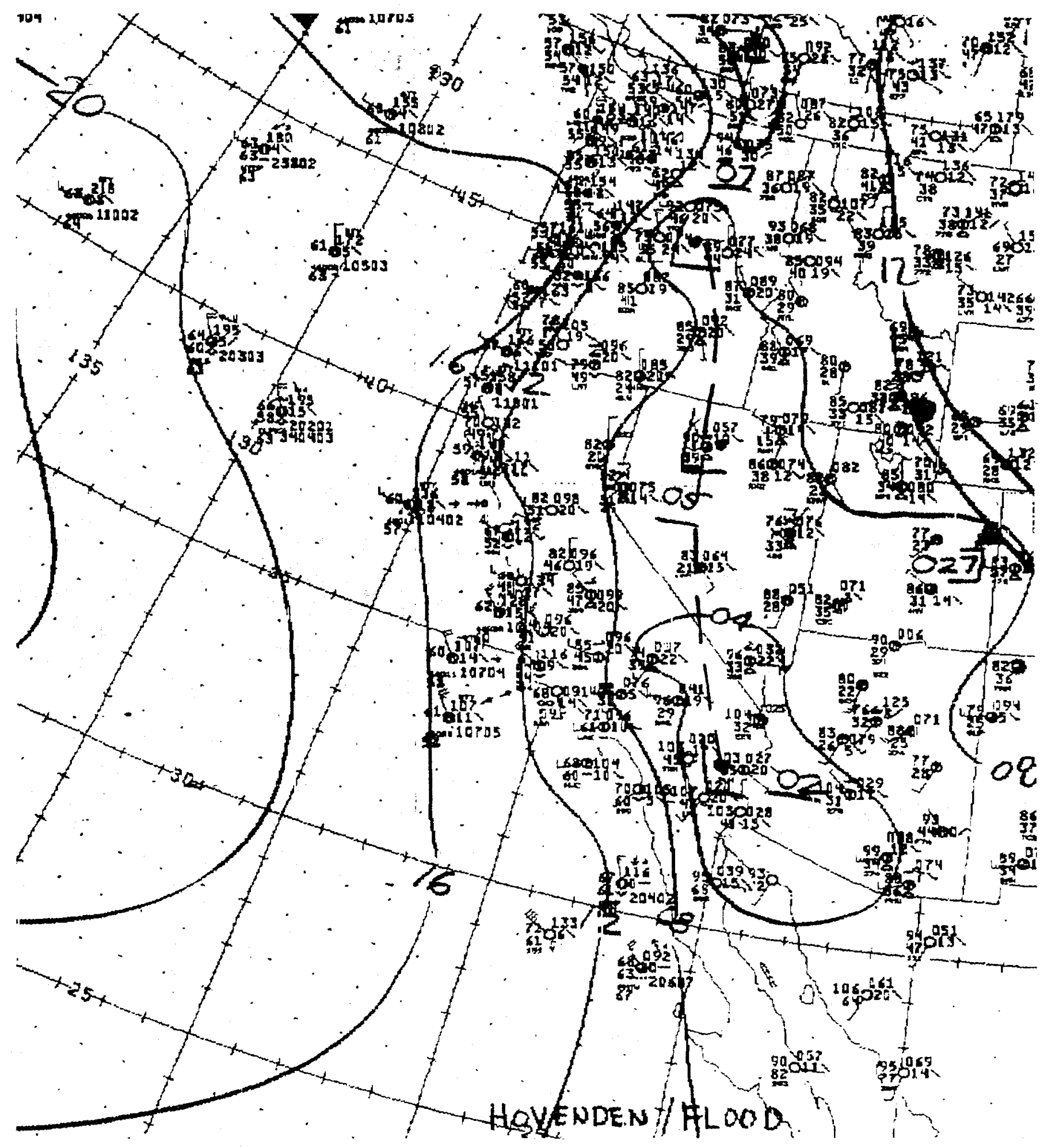

Figure A-5. Surface Weather Map for September 11, 1600 PST 


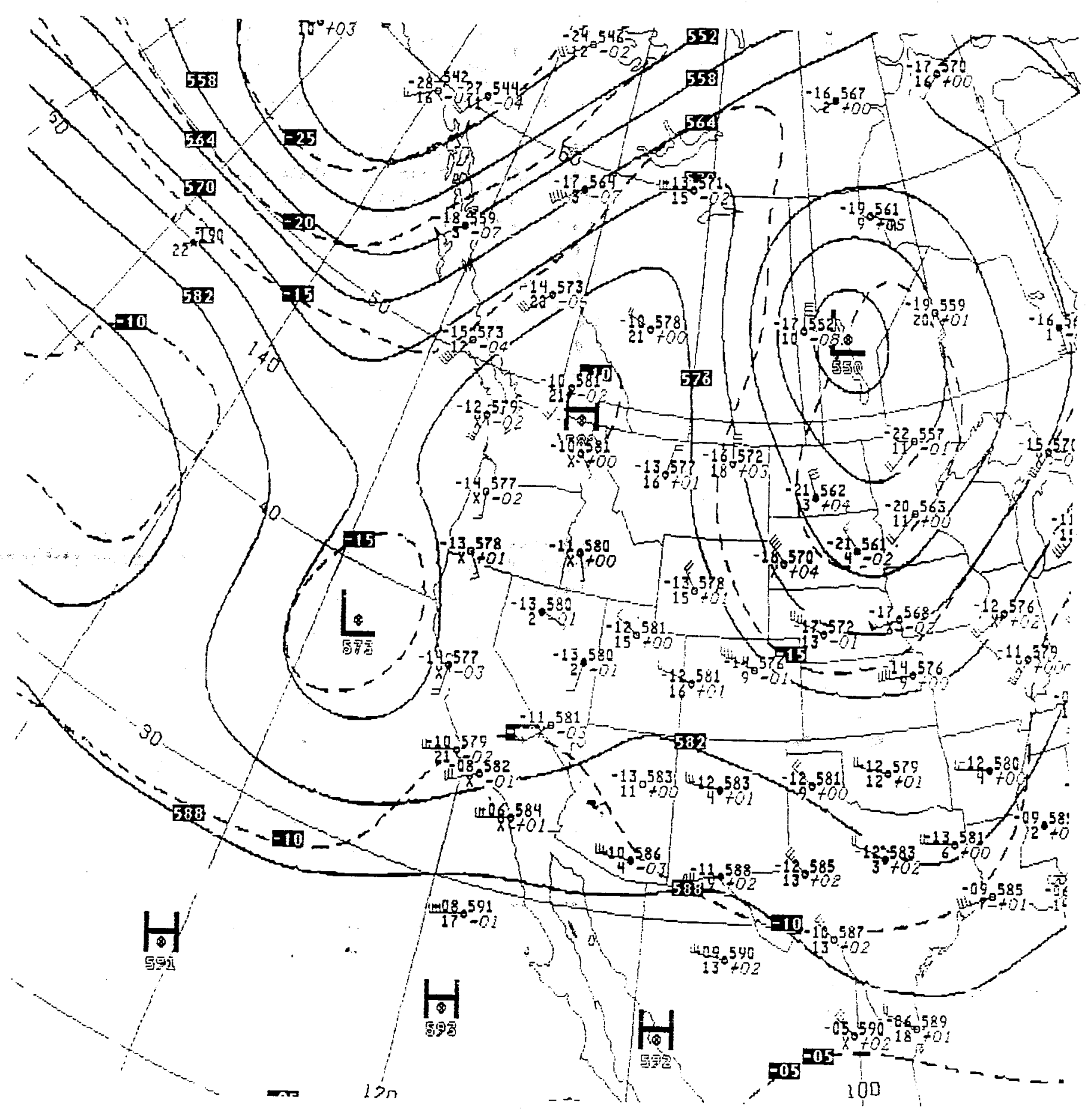

Figure A-6. 500-mb Map for September 11, 1600 PST 


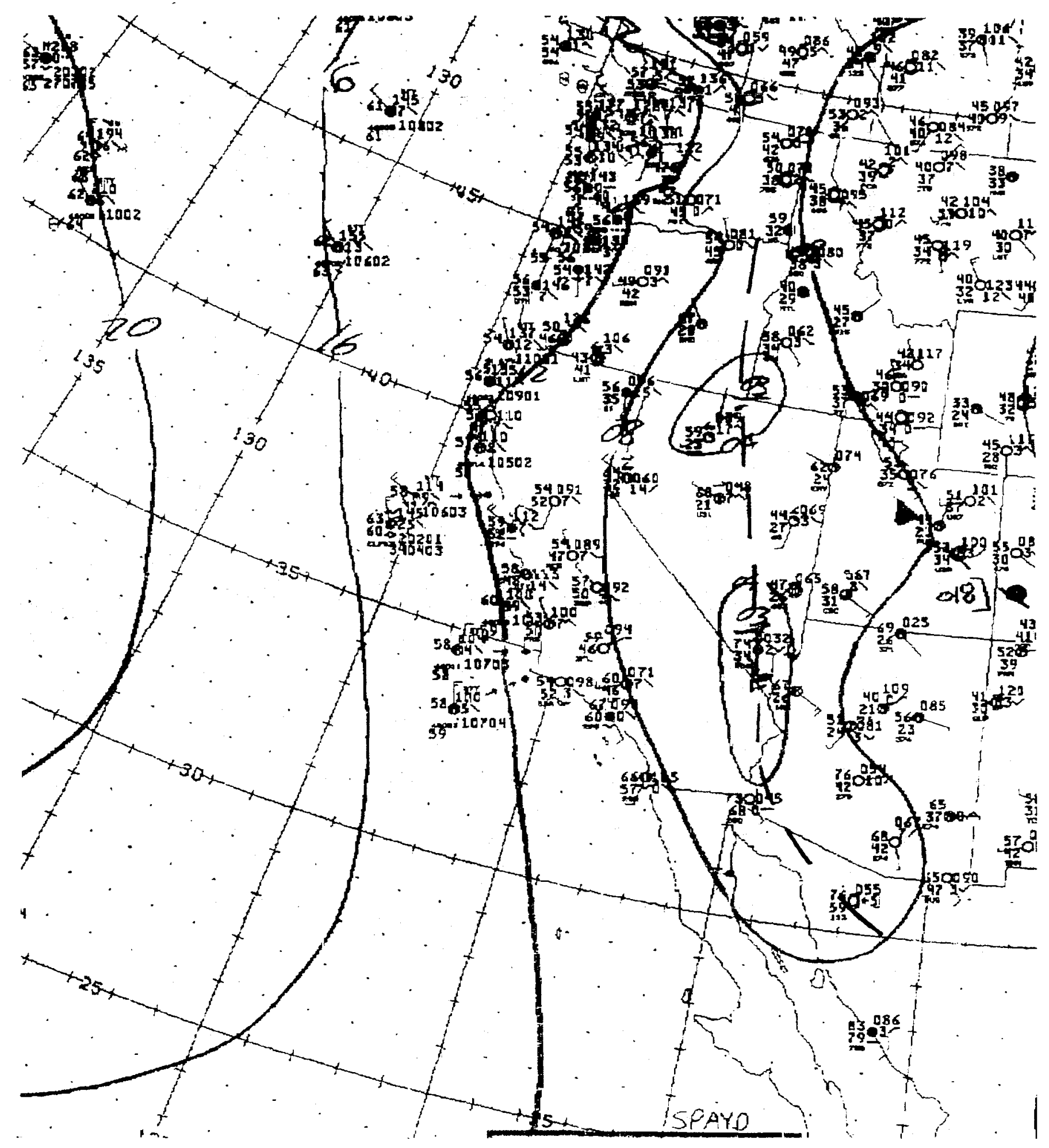

Figure A-7. Surface Weather Map for September 12, 0400 PST 


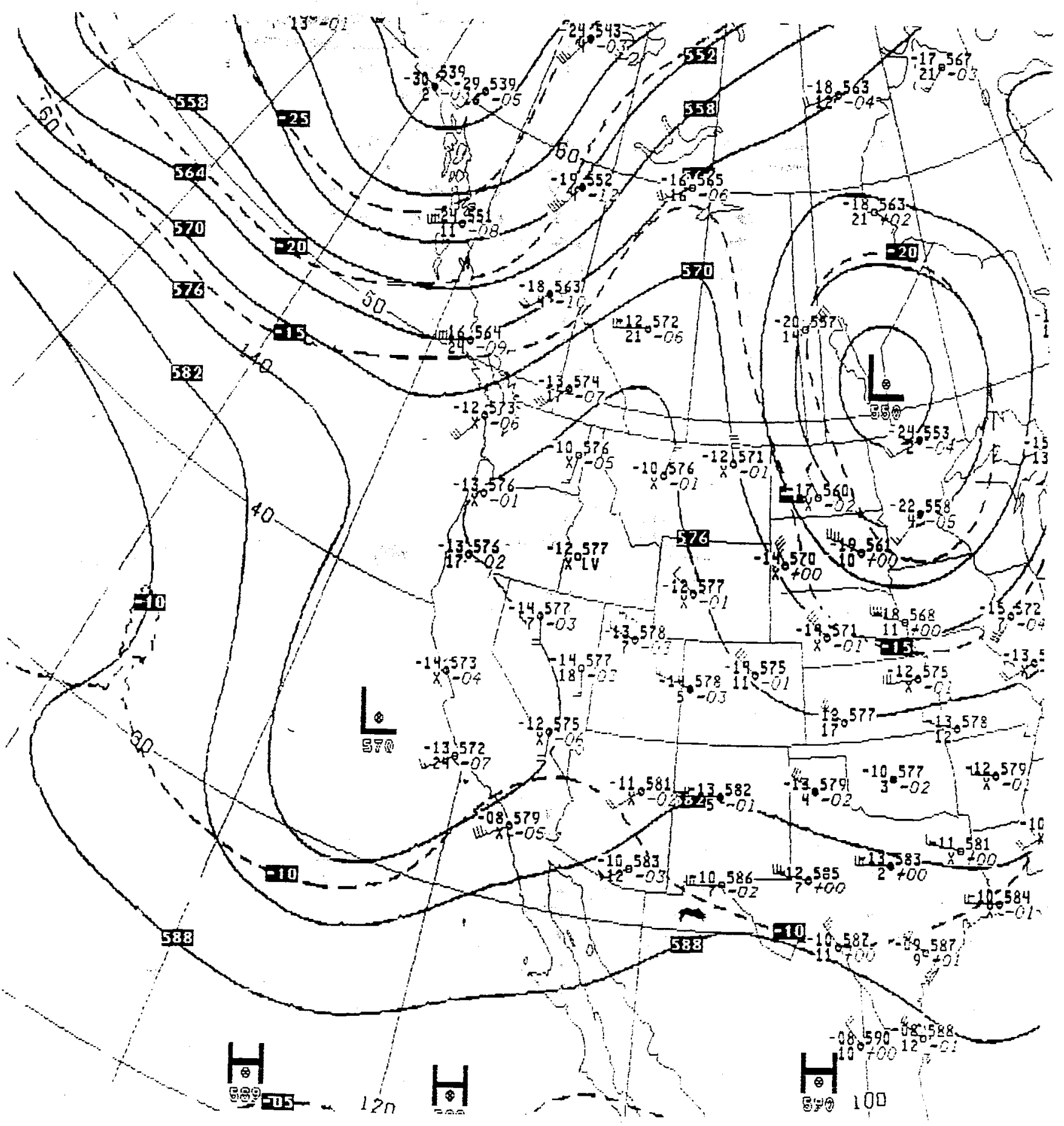

Figure A-8. 500-mb Map for September 12, 0400 PST 


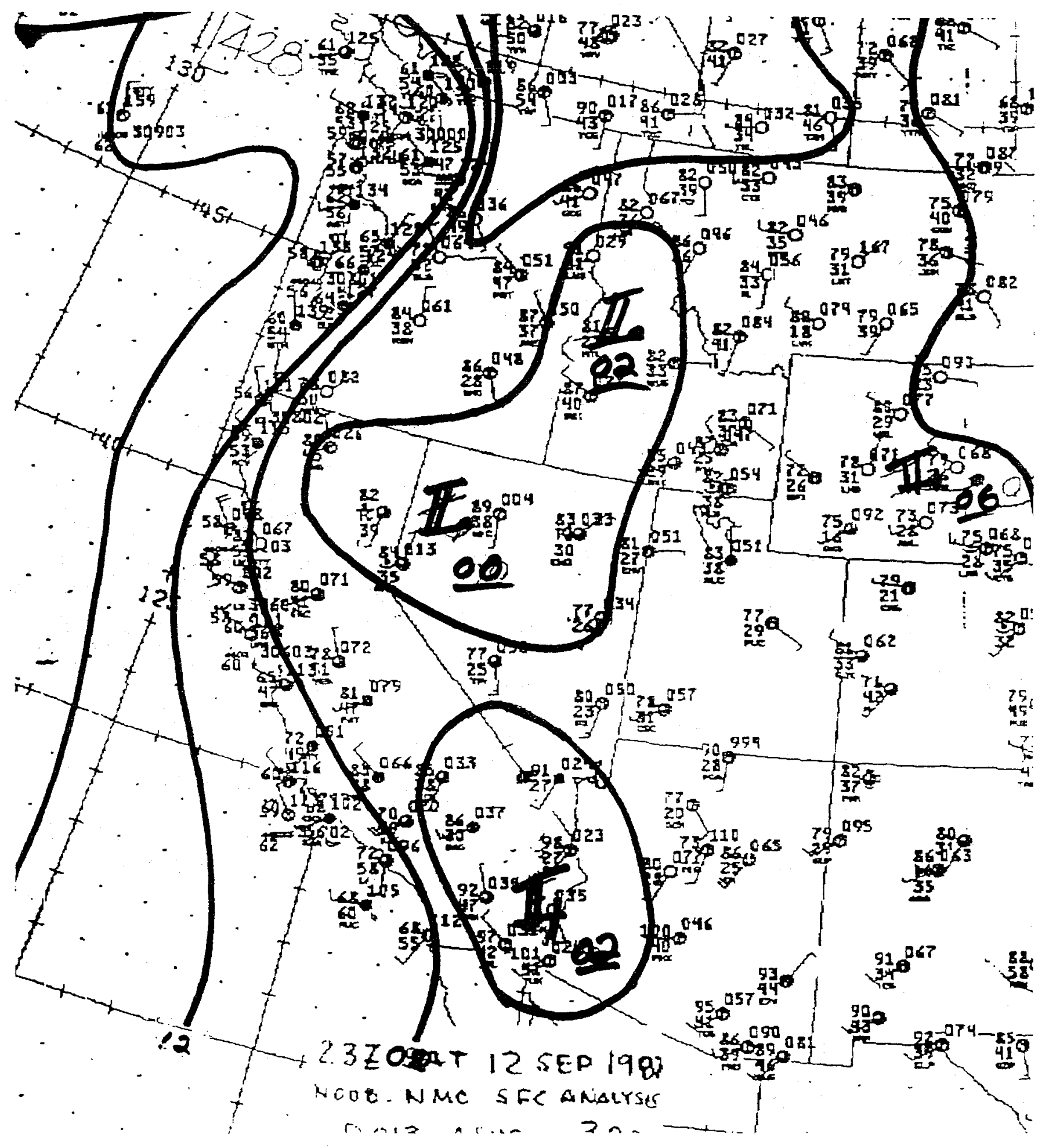

Figure A-9. Surface Weather Map for September 12, 1500 PST 


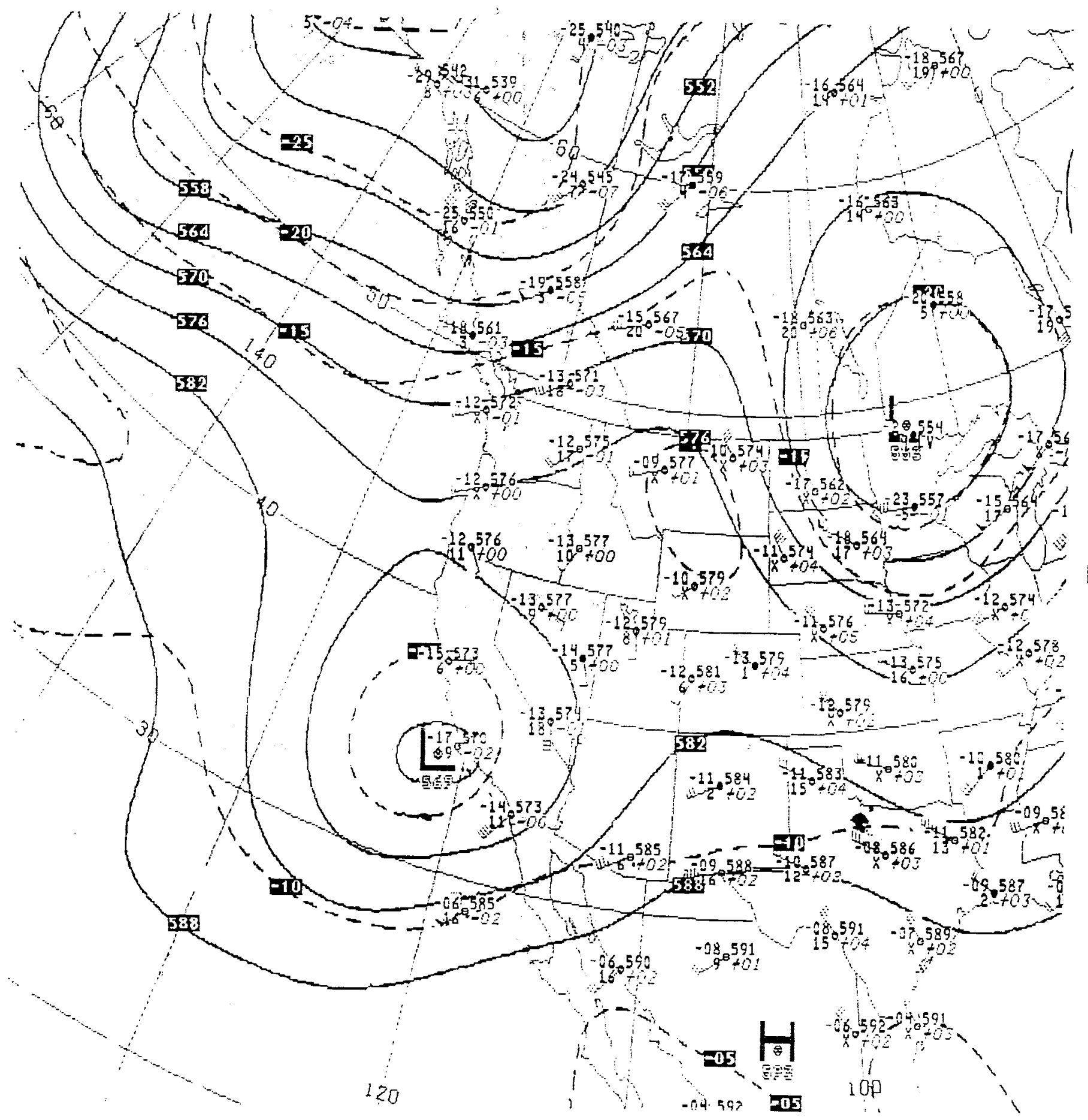

Figure A-10. 500-mb Map for September 12, 1600 PST 


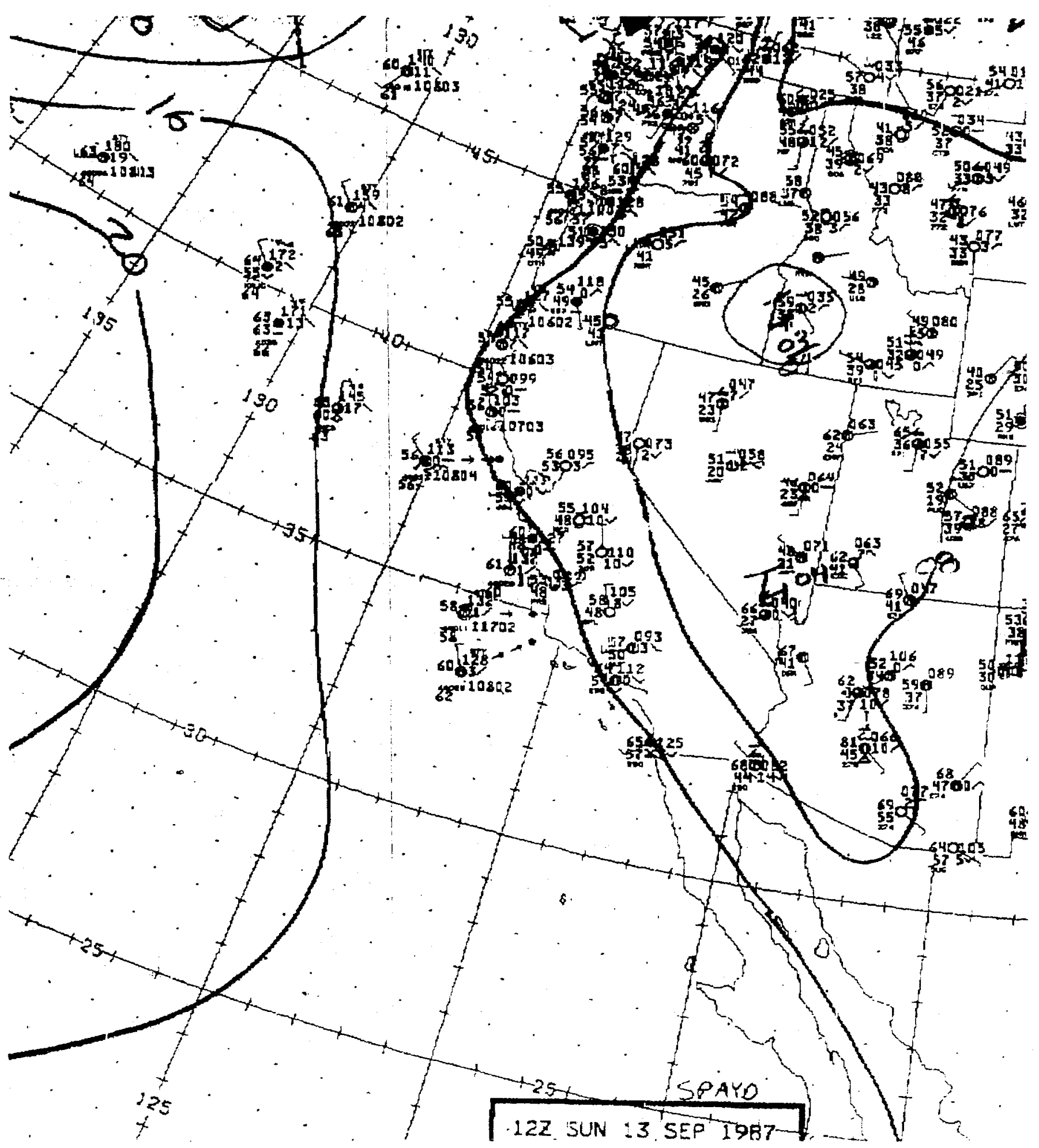

Figure A-11. Surface Weather Map for September 13, 0400 PST 


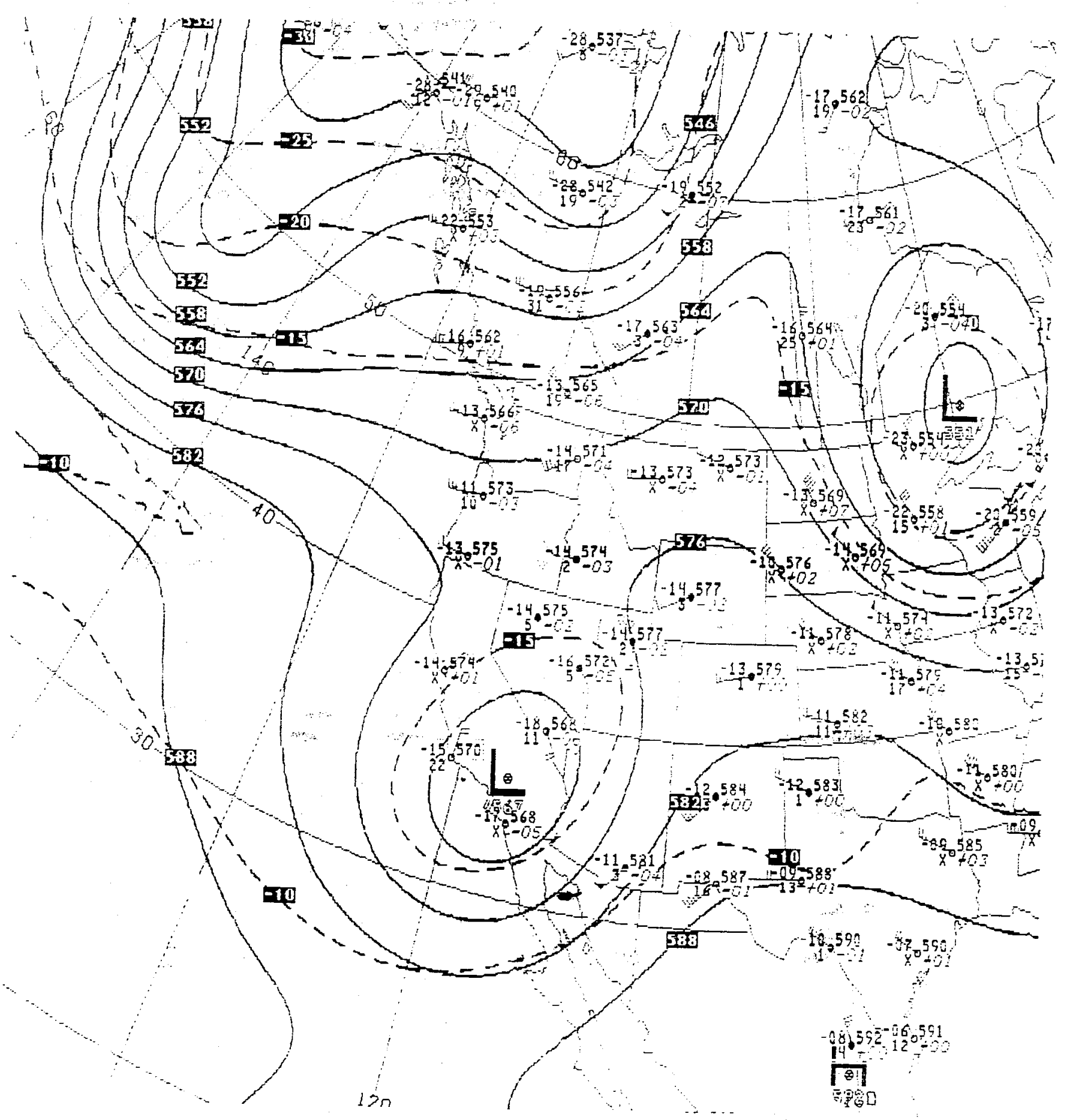

Figure A-12. 500-mb Map for September 13, 0400 PST 


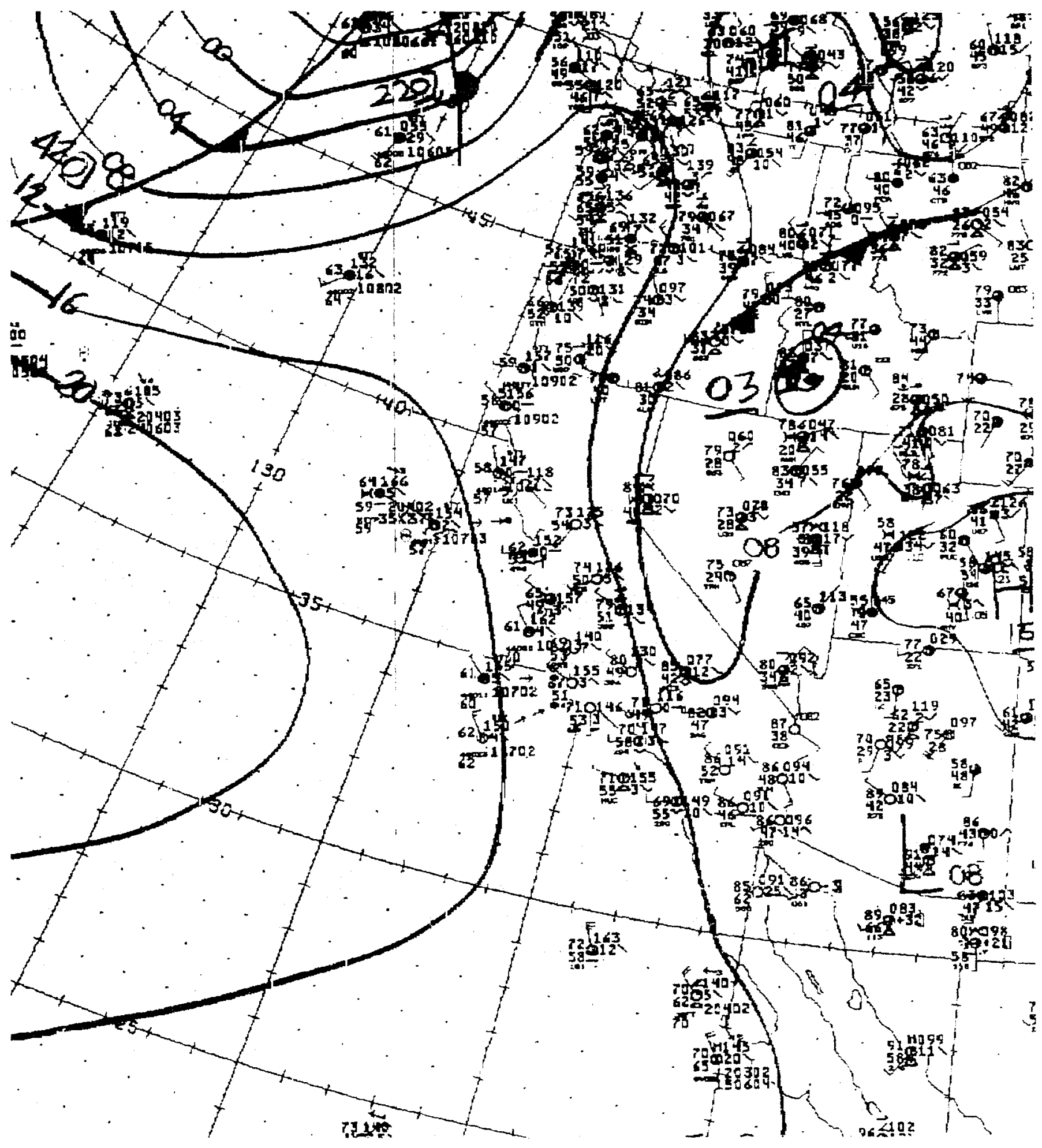

Figure A-13. Surface Weather Map for September 13, 1600 PST 


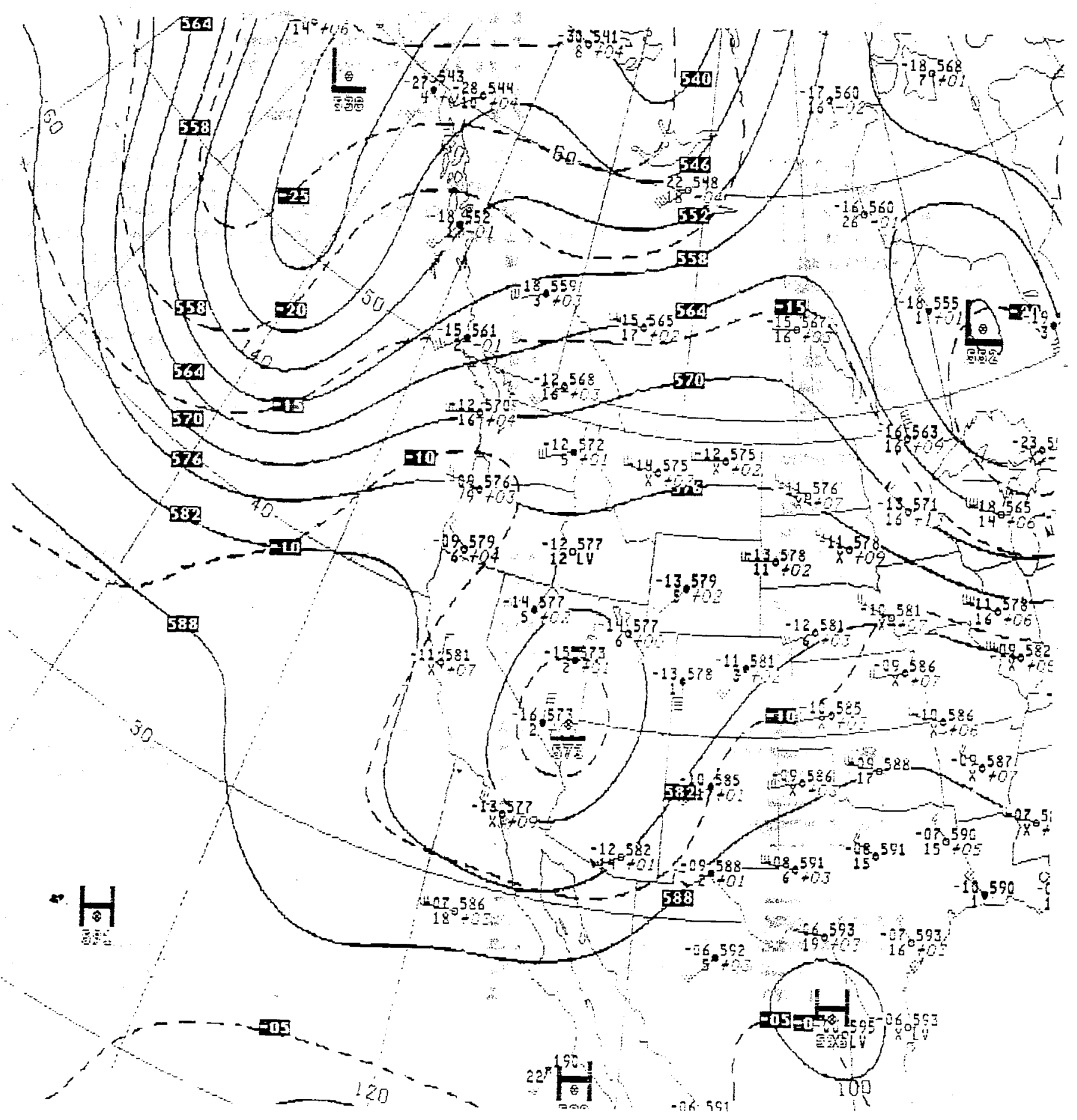

Figure A-14. 500-mb Map for September 13, 1600 PST 


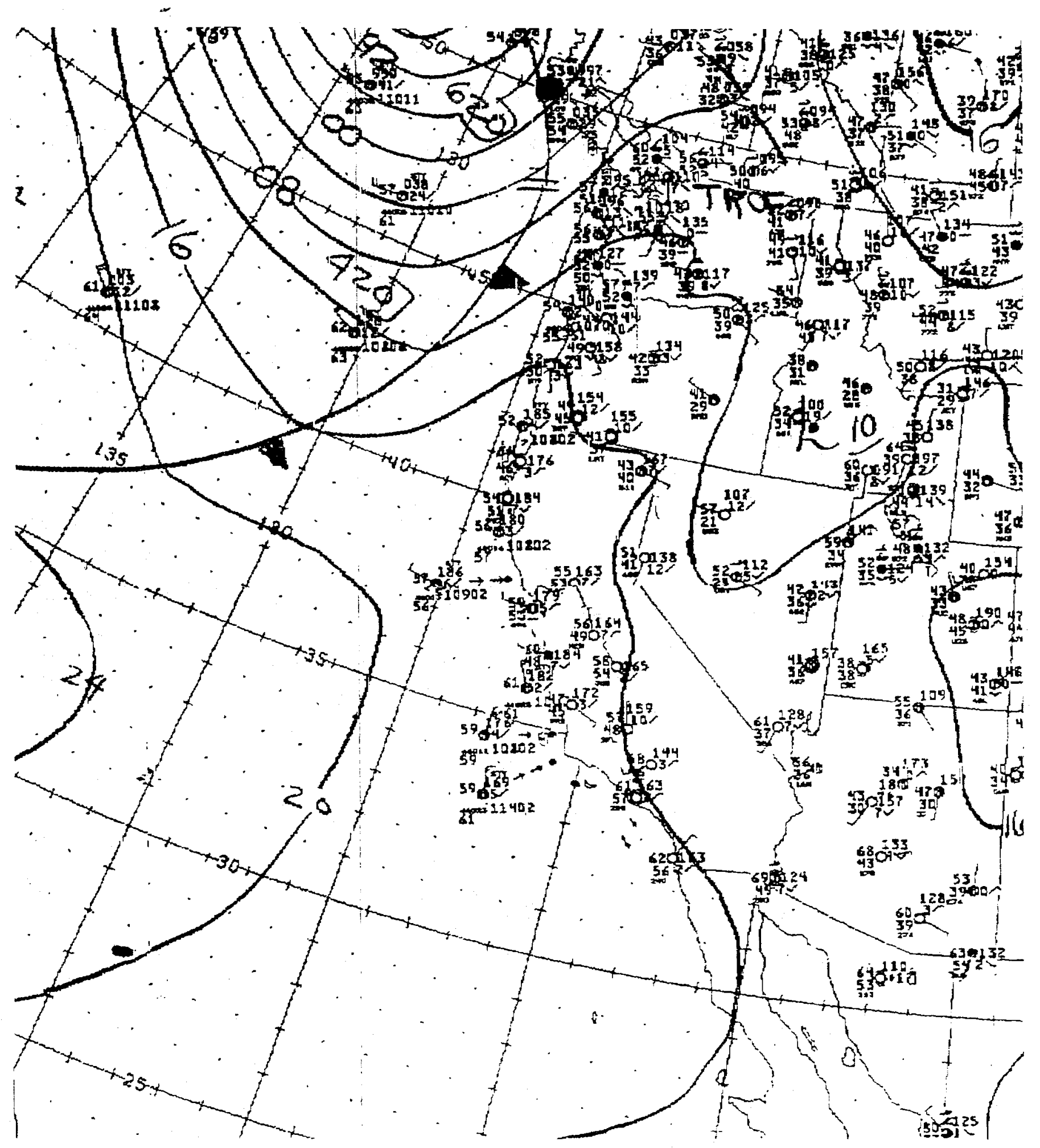

Figure A-15. Surface Weather Map for September 14, 0400 PST 


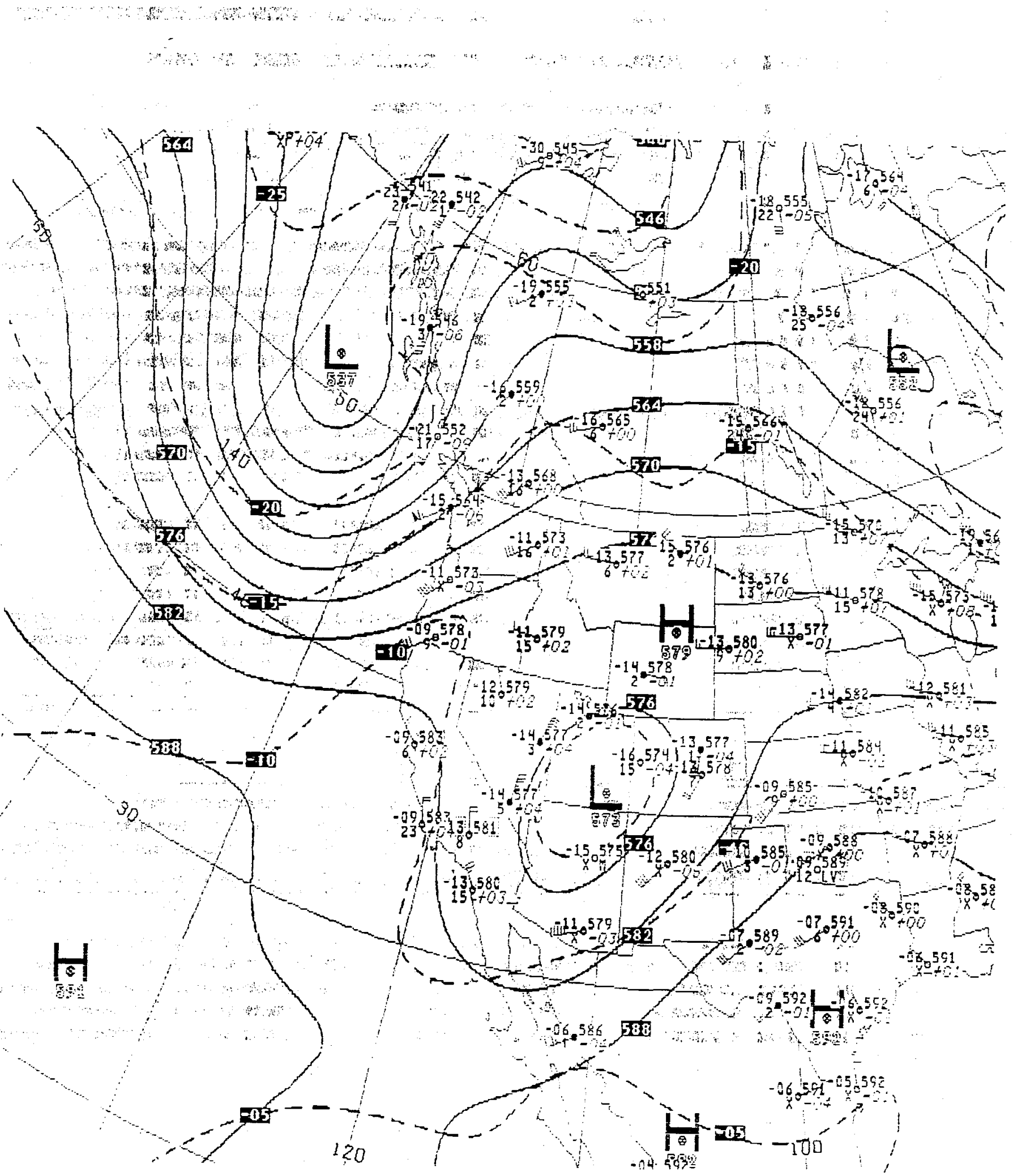

Figure A-16. 500-mb Map for September 14, 0400 PST 


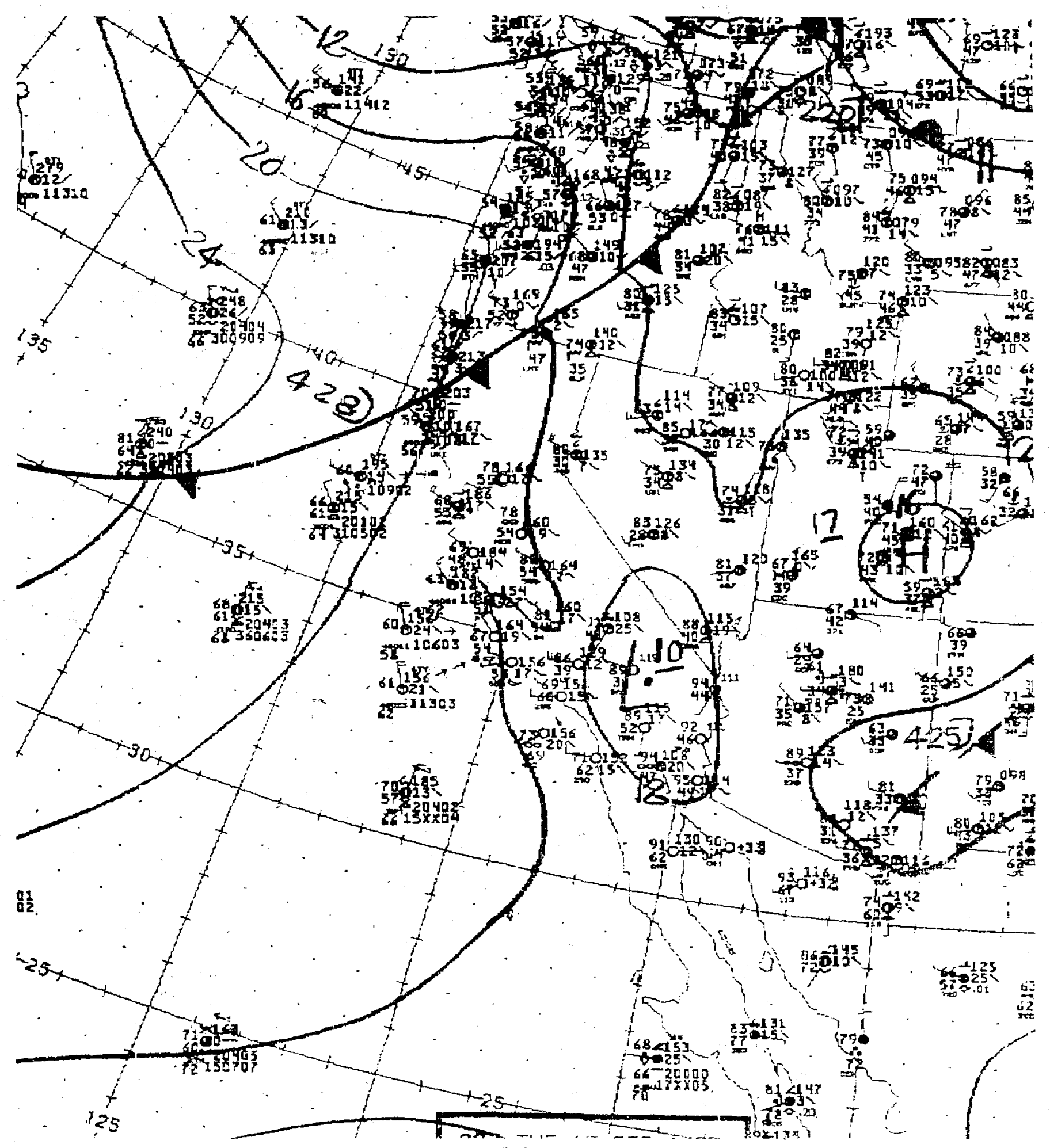

Figure A-17. Surface Weather Map for September 14, 1600 PST 


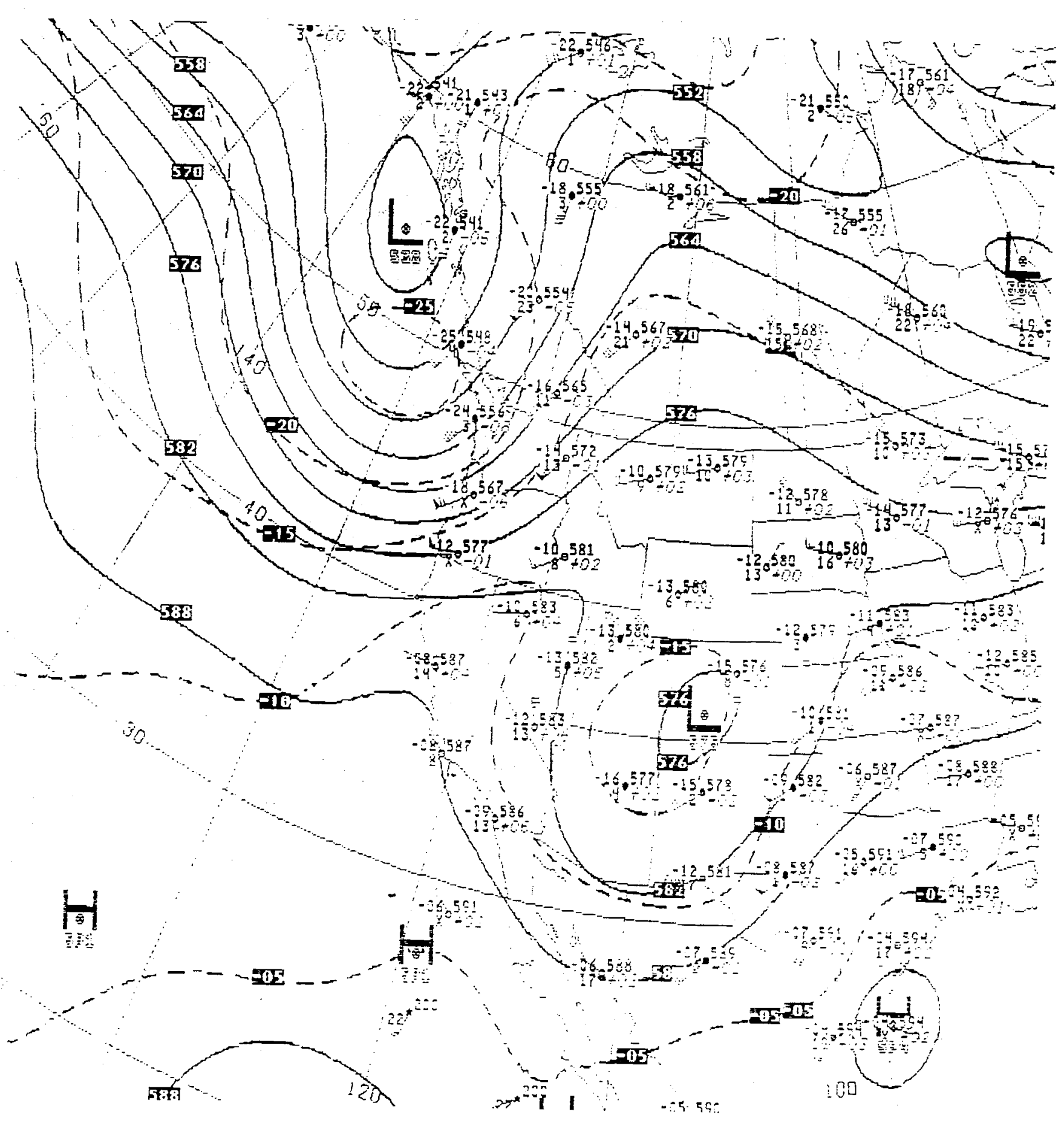

Figure A-18. 500-mb Map for September 14, 1600 PST 


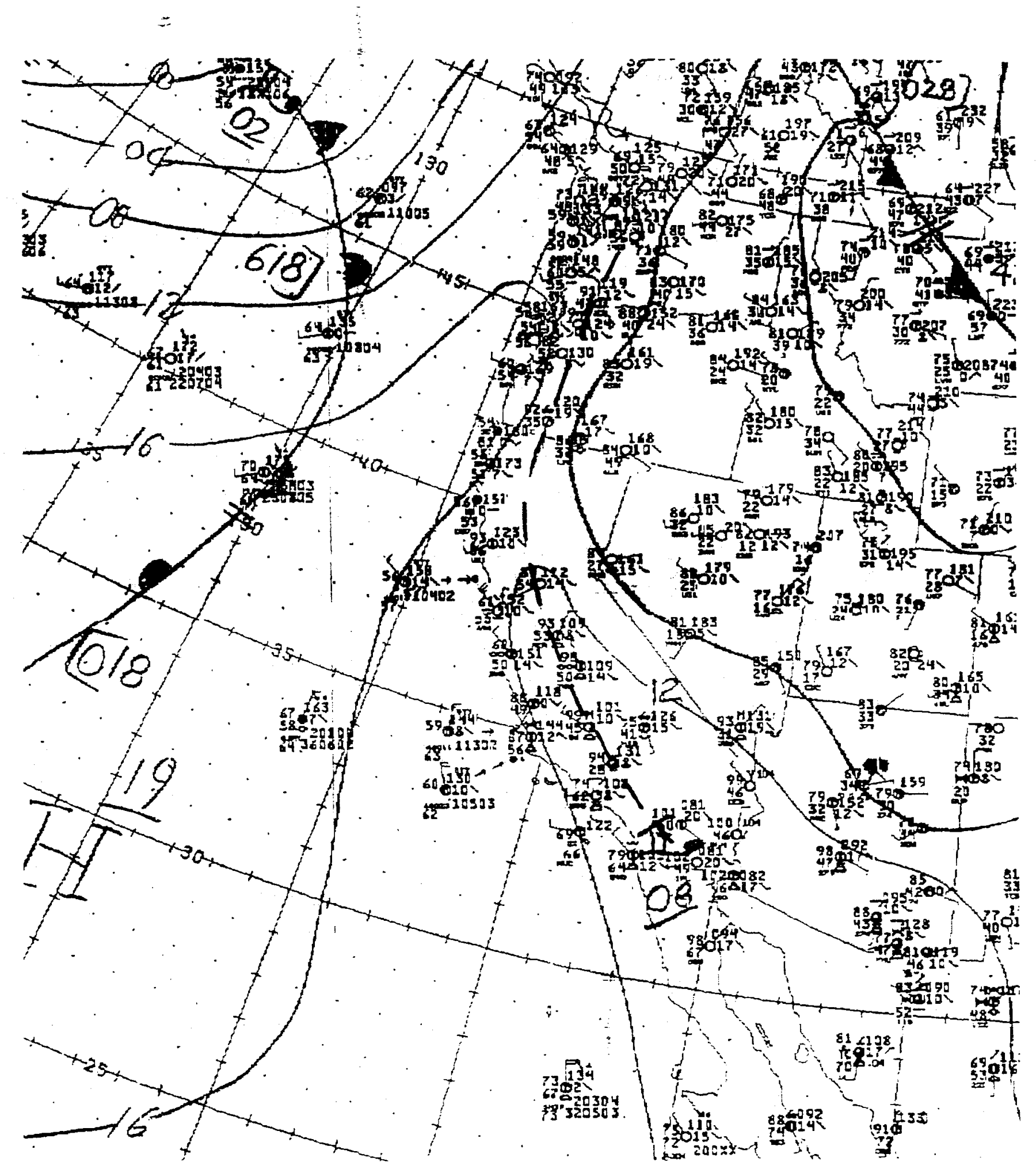

Figure A-19. Surface Weather Map for October 1, 1600 PST 


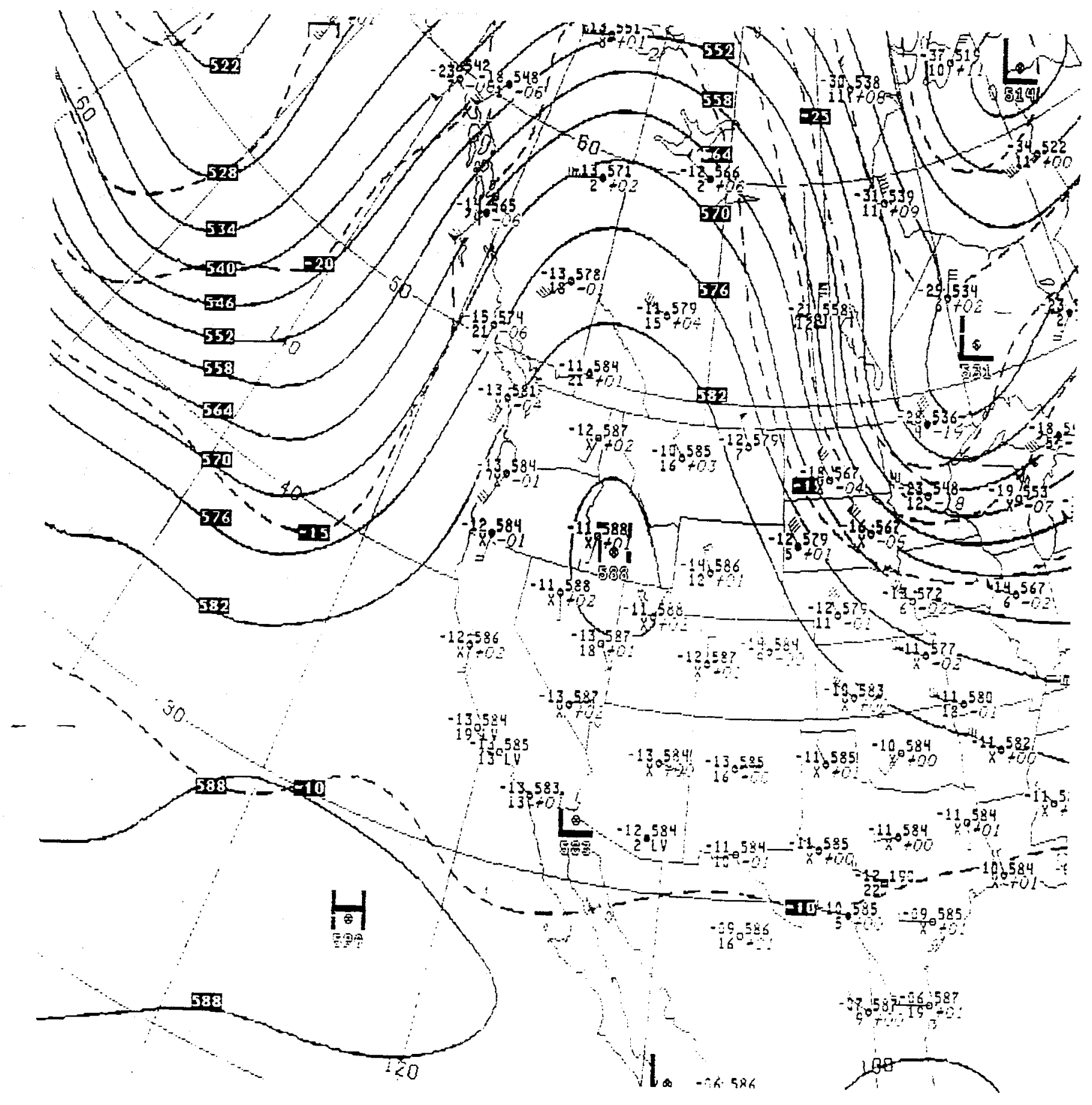

Figure A-20. 500-mb Map for October 1, 1600 PST 


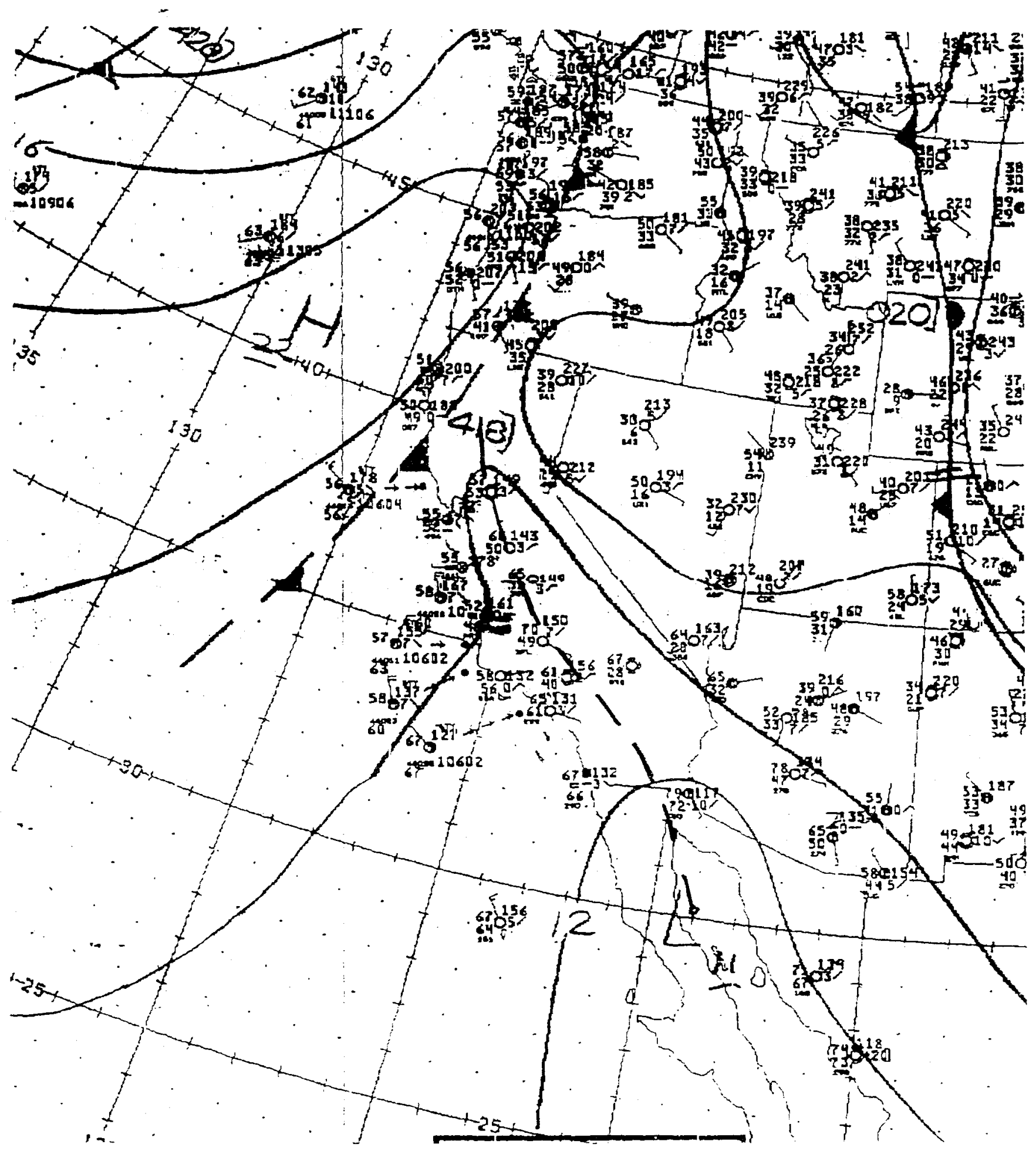

Figure A-21. Surface Weather Map for October 2, 0400 PST 


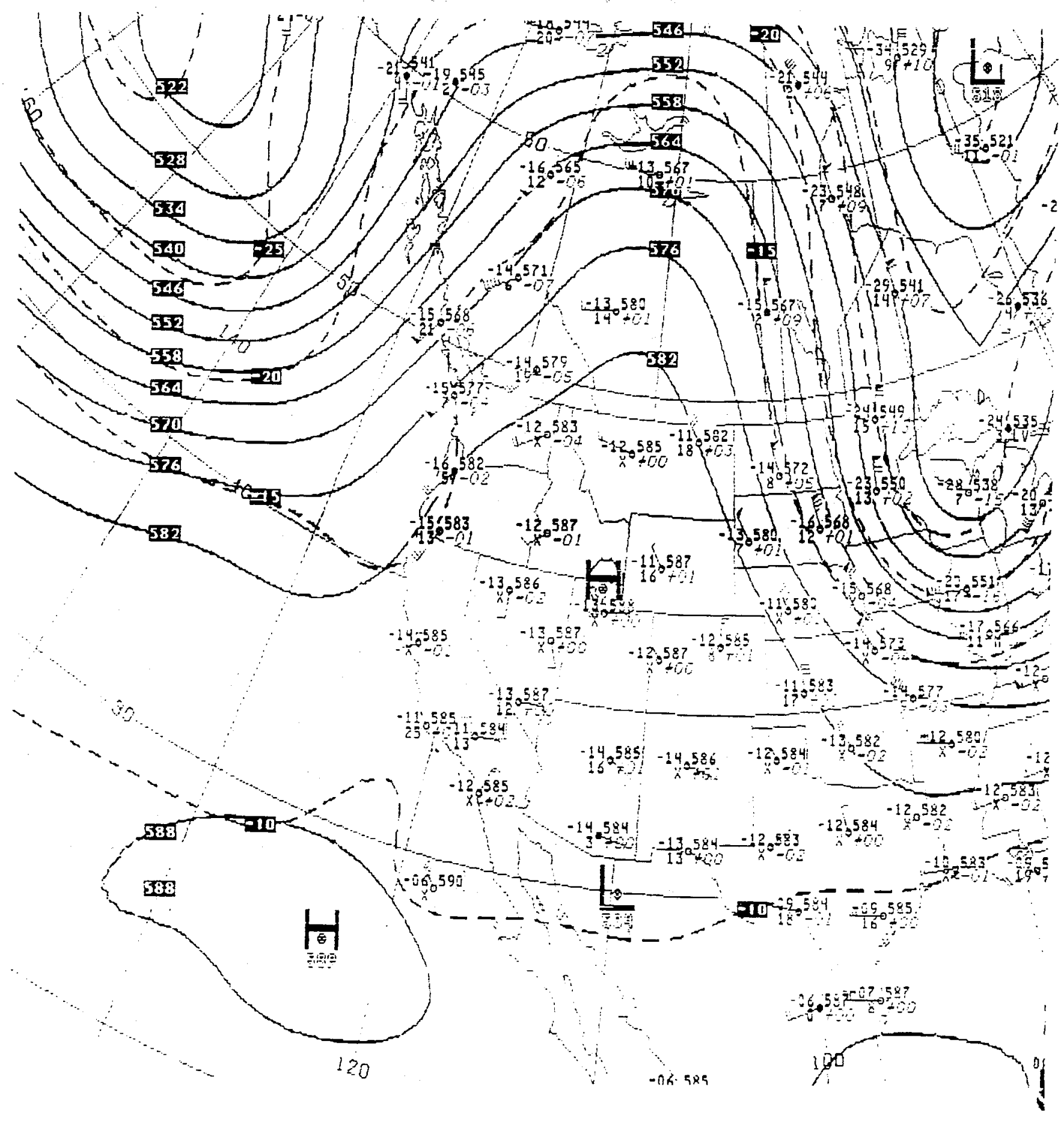

Figure A-22. 500-mb Map for October 2, 0400 PST 


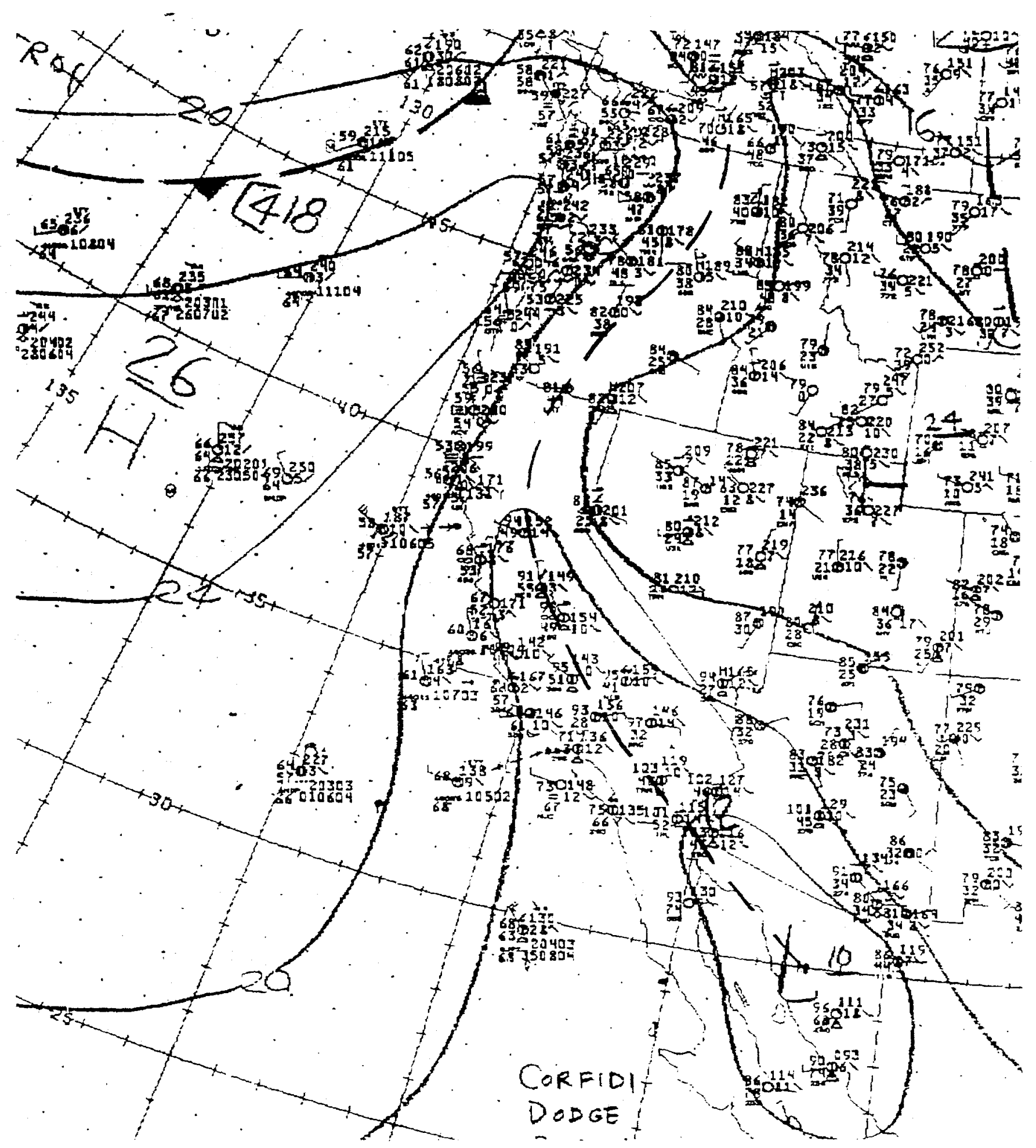

Figure A-23. Surface Weather Map for October 2, 1600 PST 


\section{SEPI}

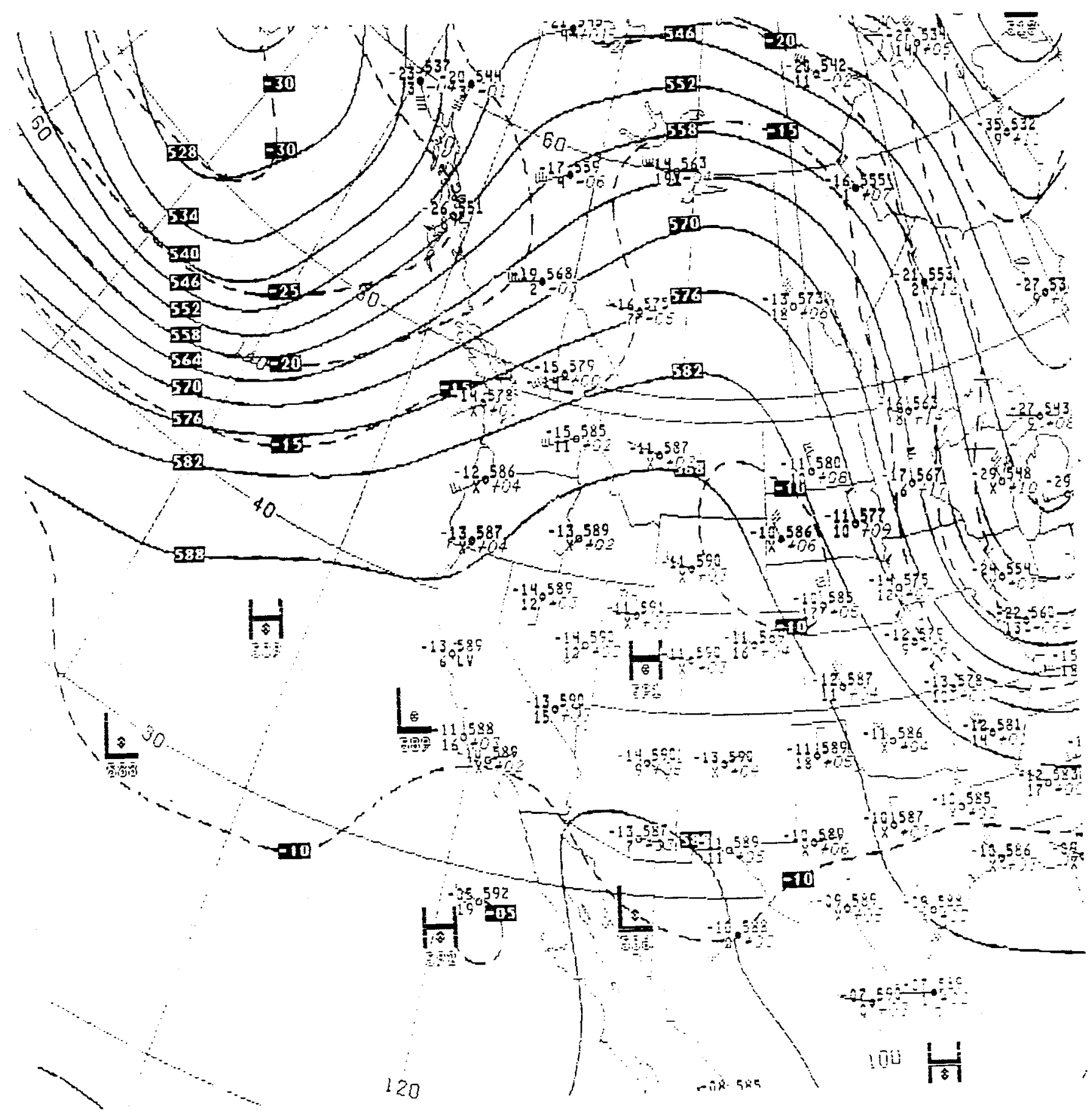

Figure A-24. 500-mb Map for October 2, 1600 PST 


\section{SEPI}

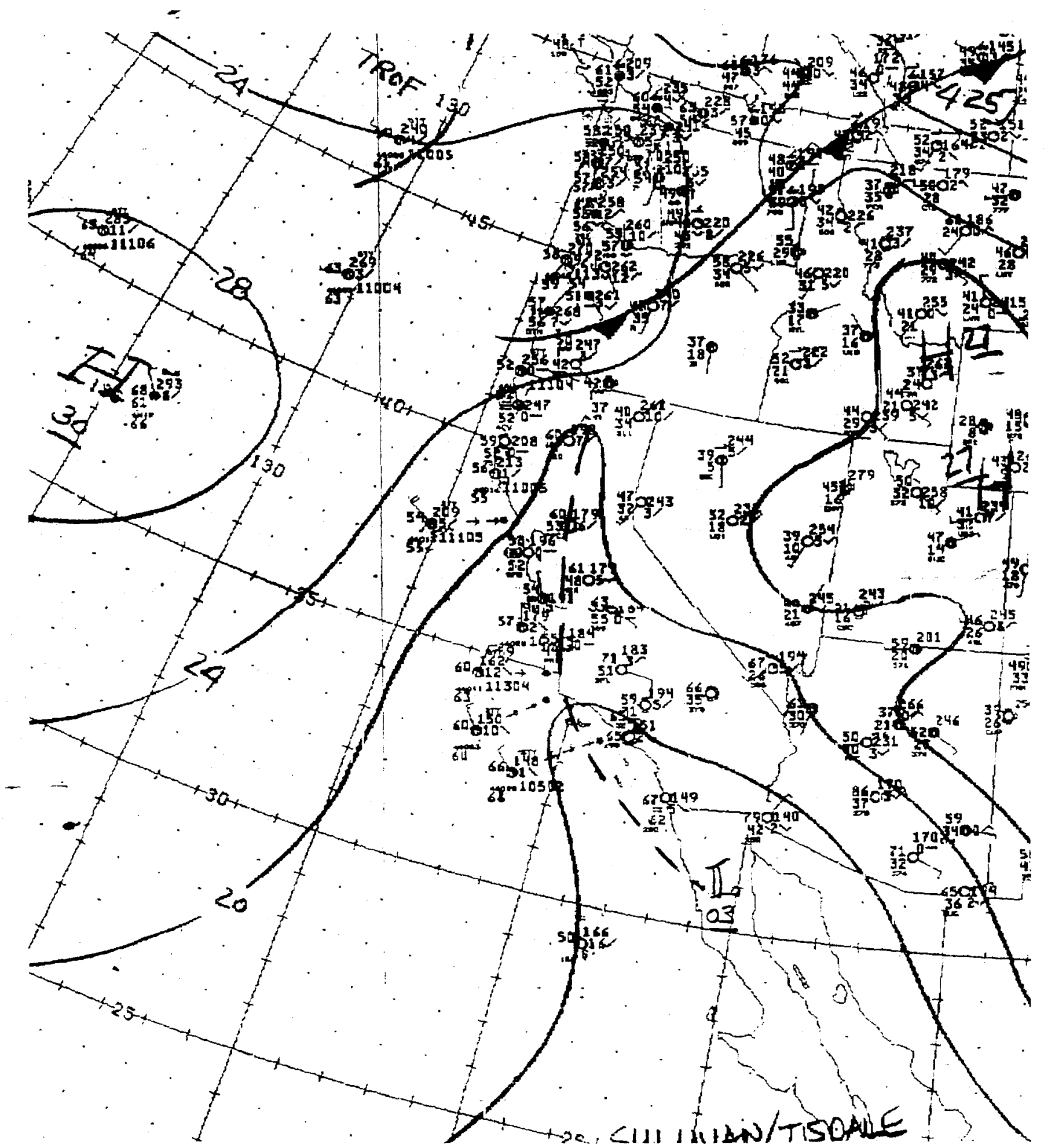

Figure A-25. Surface Weather Map for October 3, 0400 PST 


\section{EEPI}

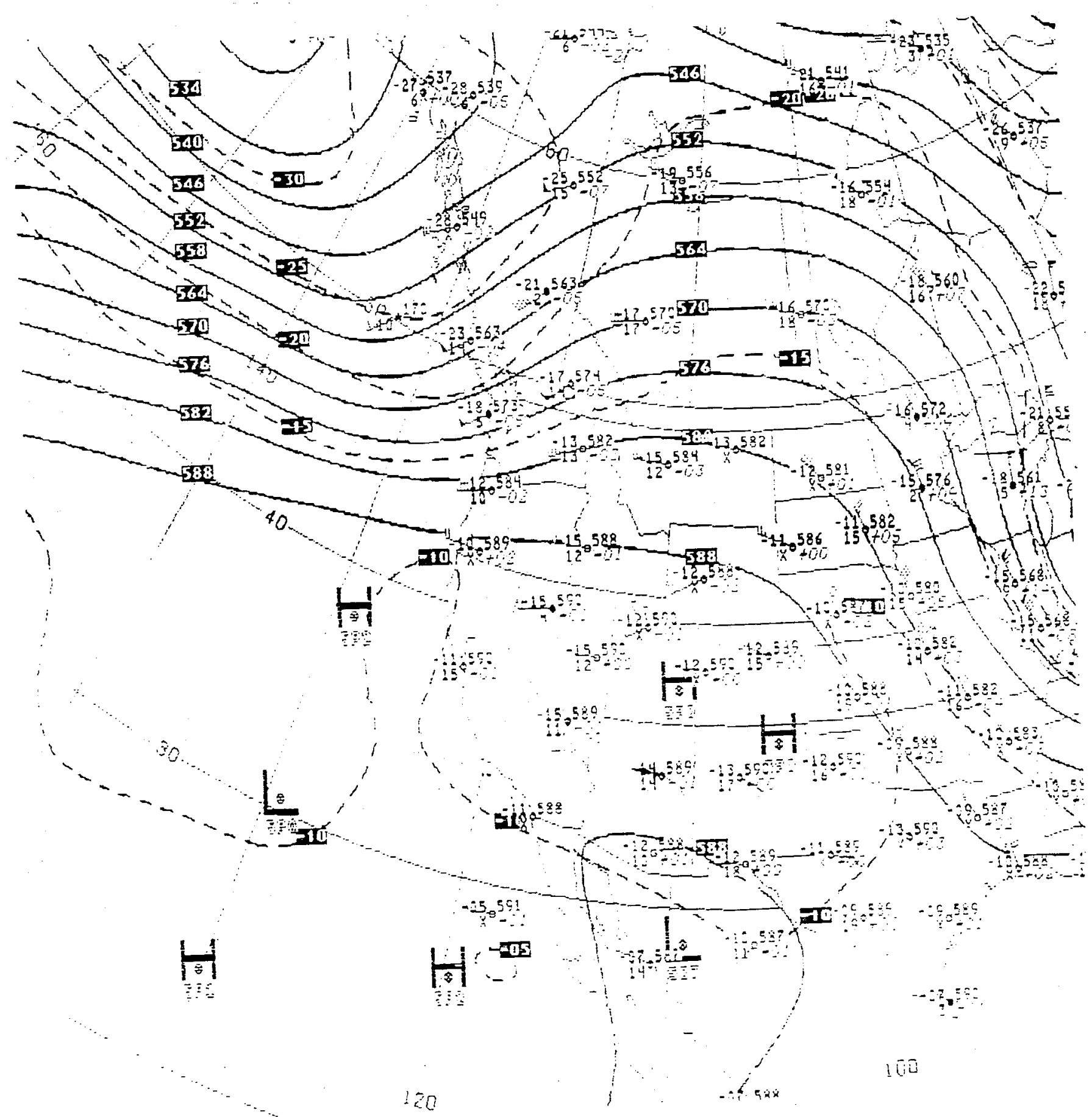

Figure A-26. 500-mb Map for October 3, 0400 PST 


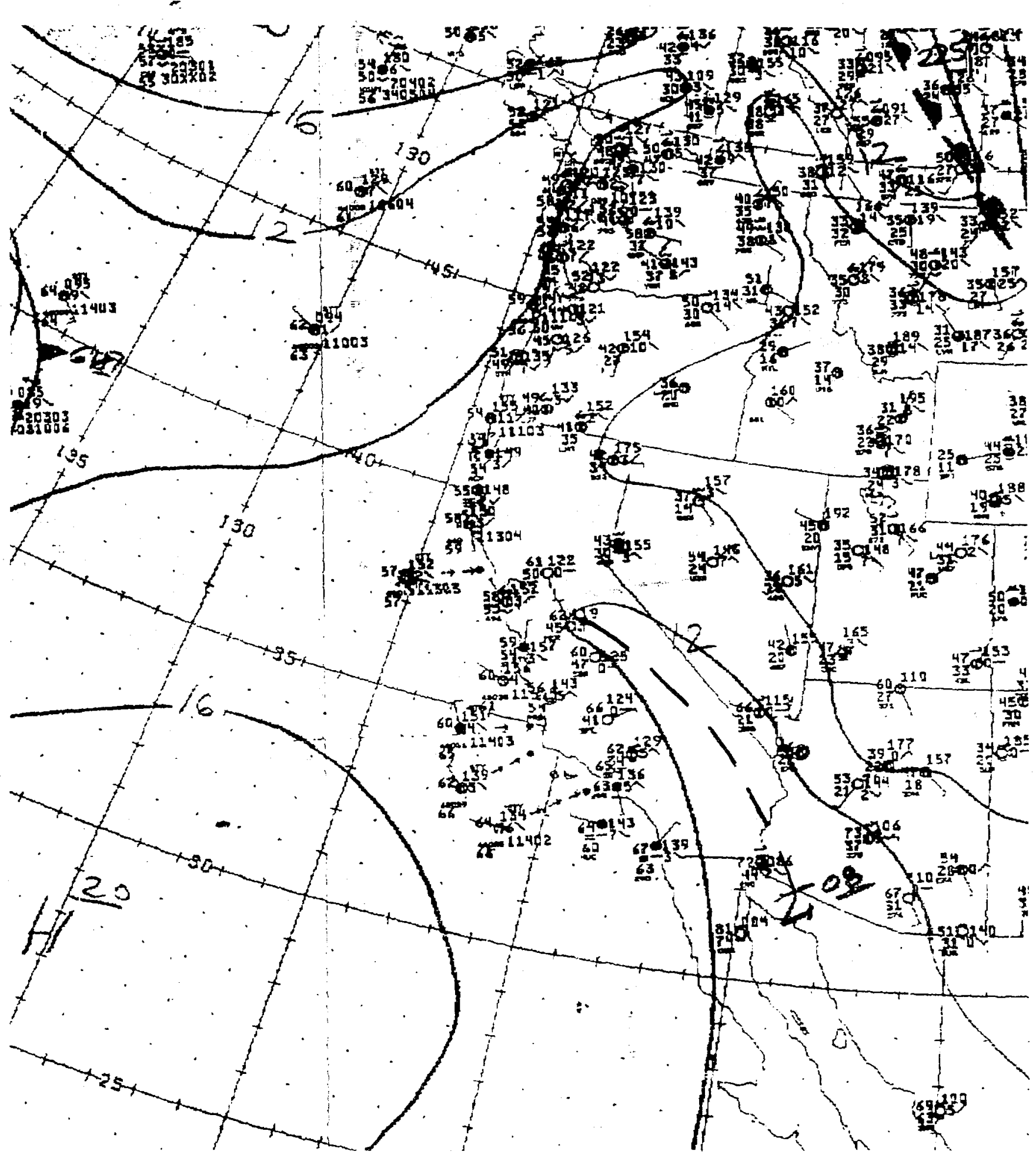

Figure A-27. Surface Weather Map for October 7, 0400 PST 


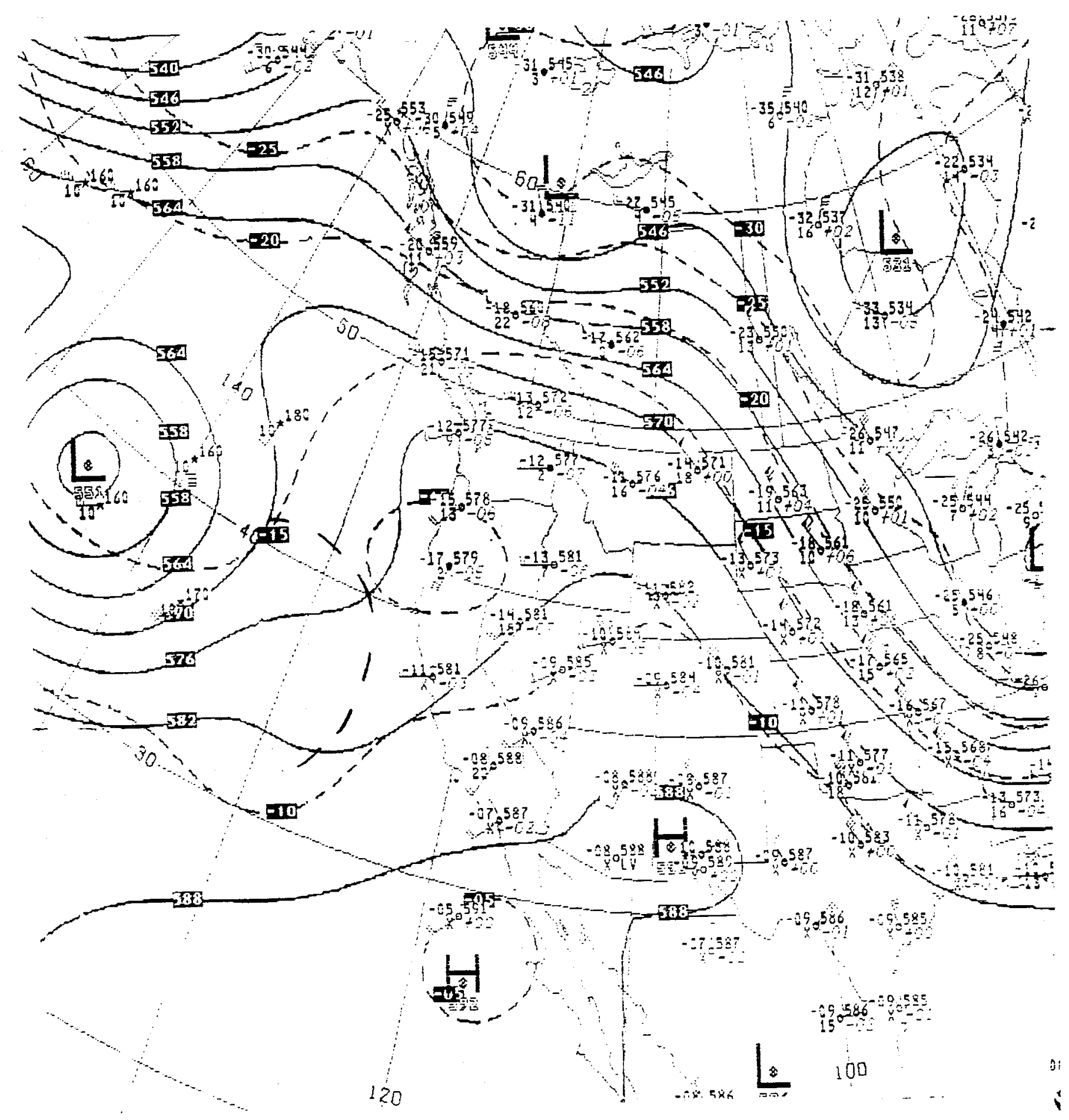

Figure A-28. 500-mb Map for October 7, 0400 PST 


\section{SEP1 :}

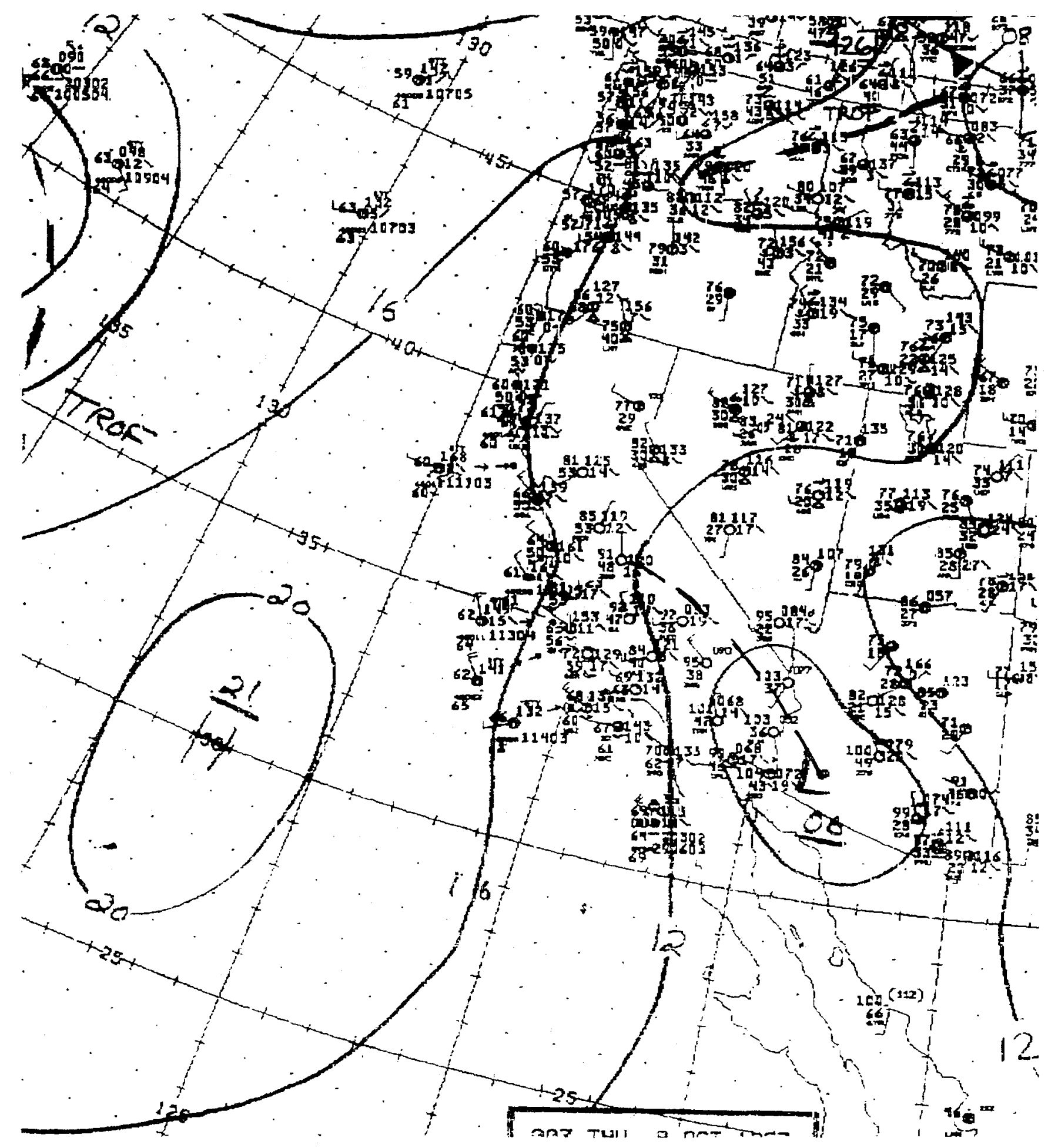

Figure A-29. Surface Weather Map for October 7, 1600 PST 


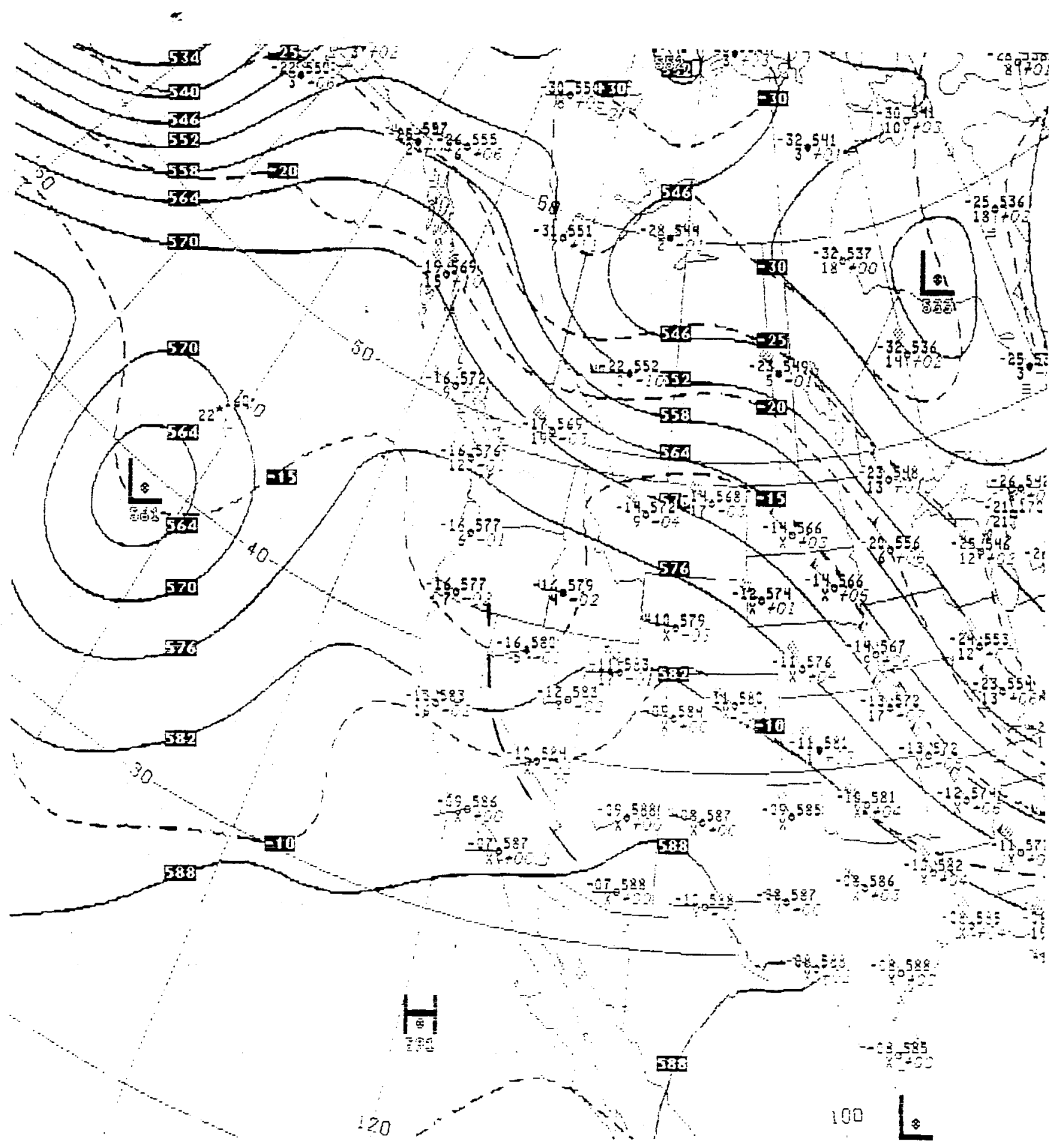

Figure A-30. 500-mb Map for October 7, 1600 PST 


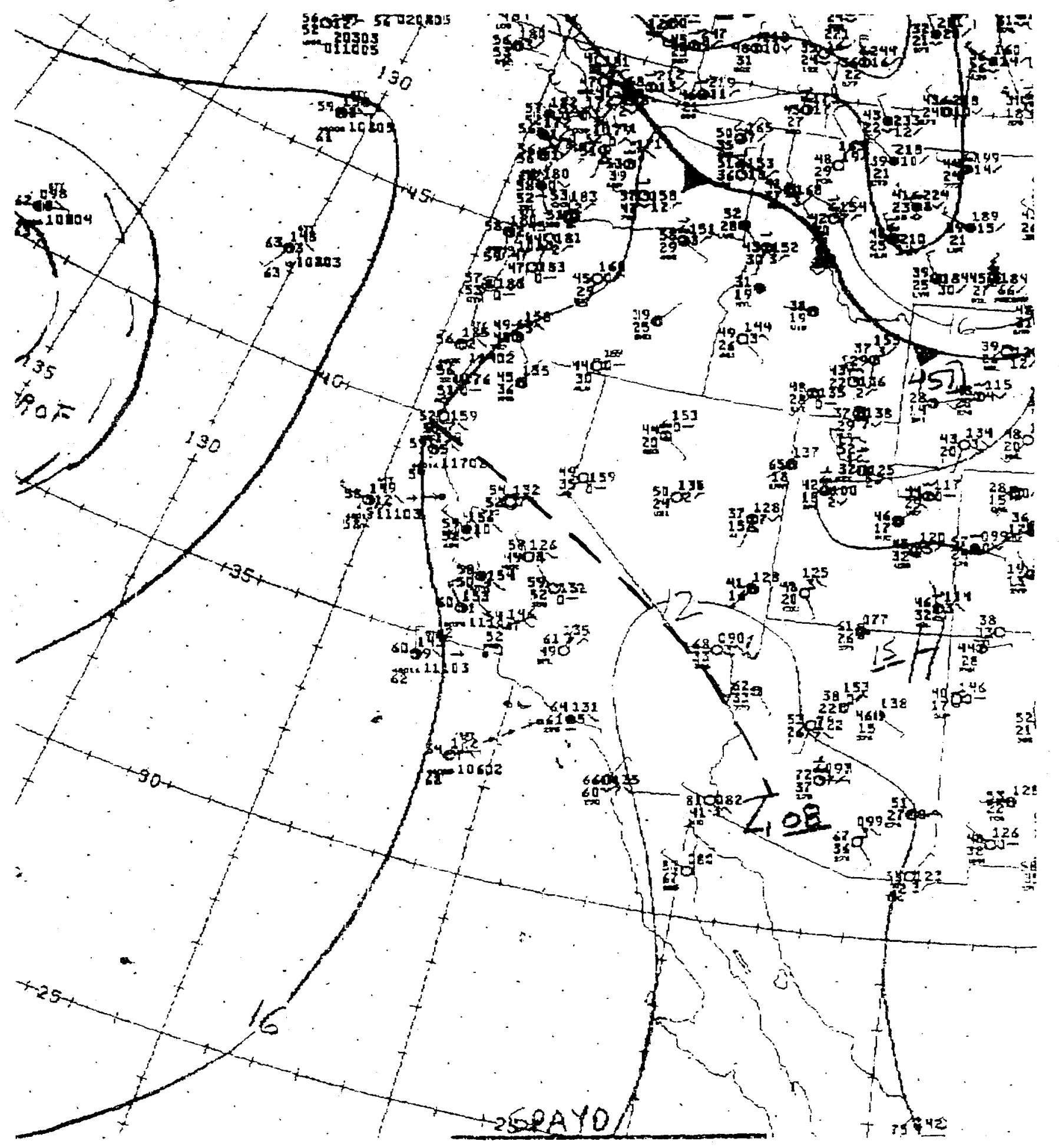

Figure A-31. Surface Weather Map for October 8, 0400 PST 


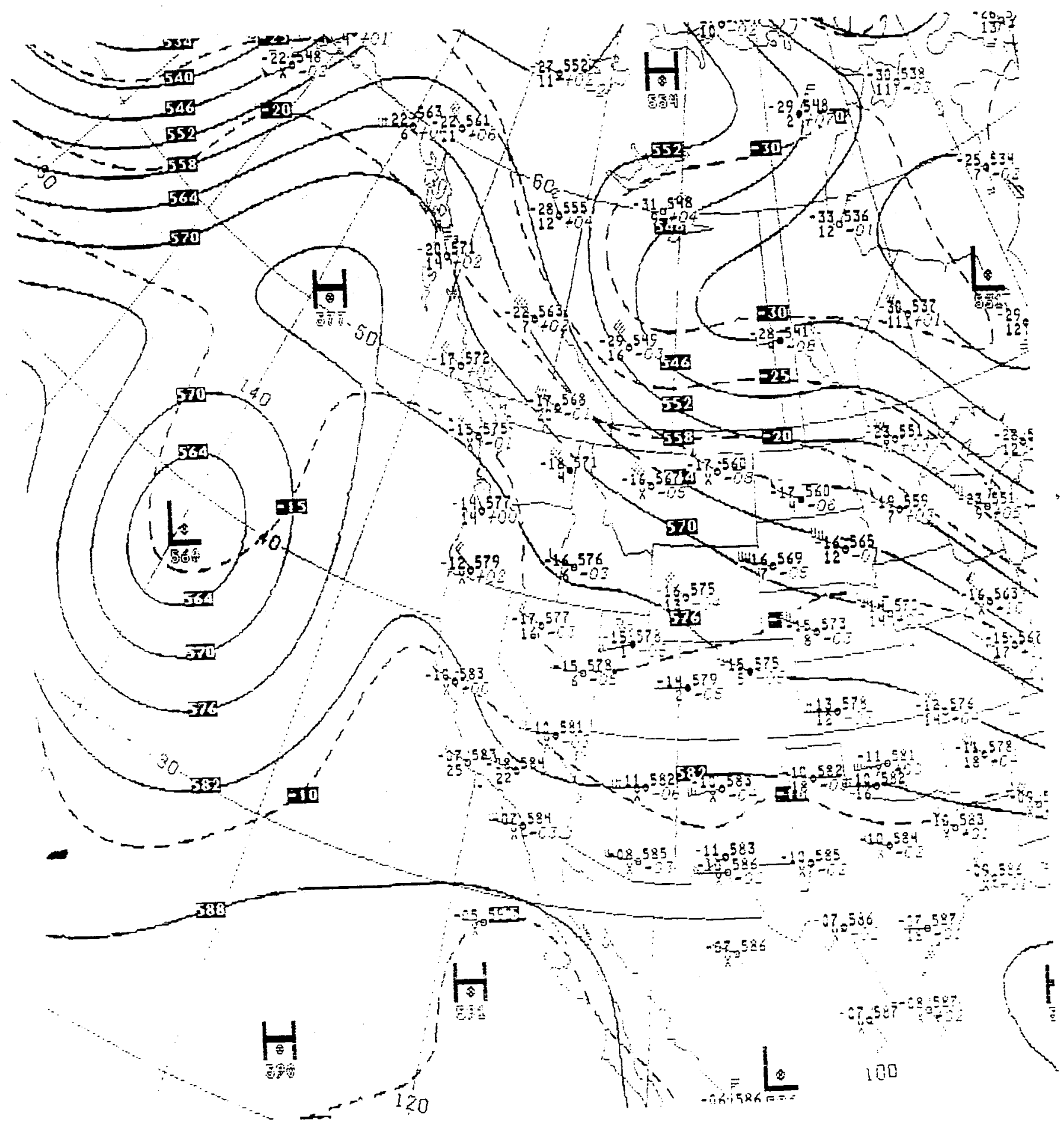

Figure A-32. 500-mb Map for October 8, 0400 PST 


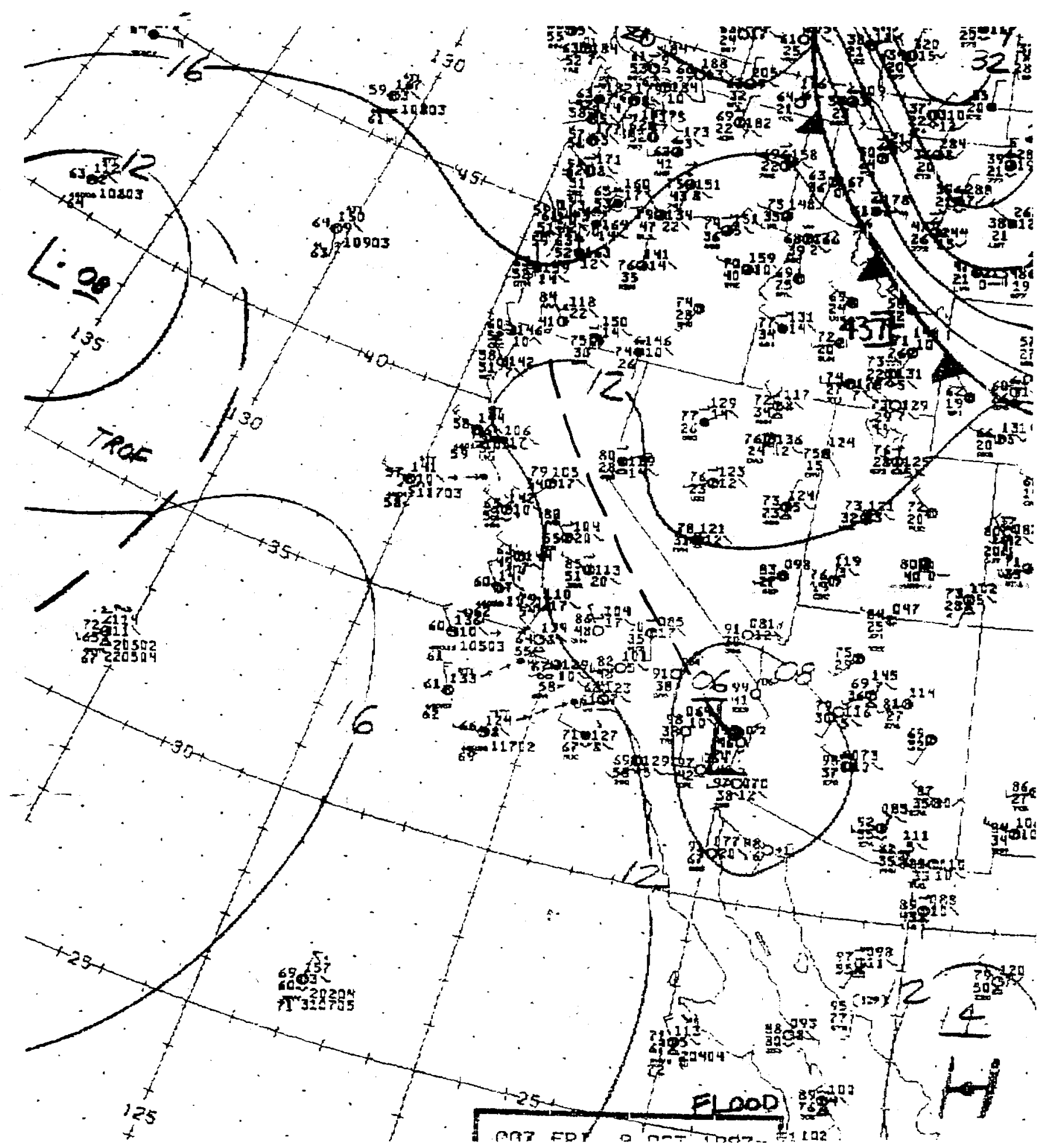

Figure A-33. Surface Weather Map for October 8, 1600 PST 


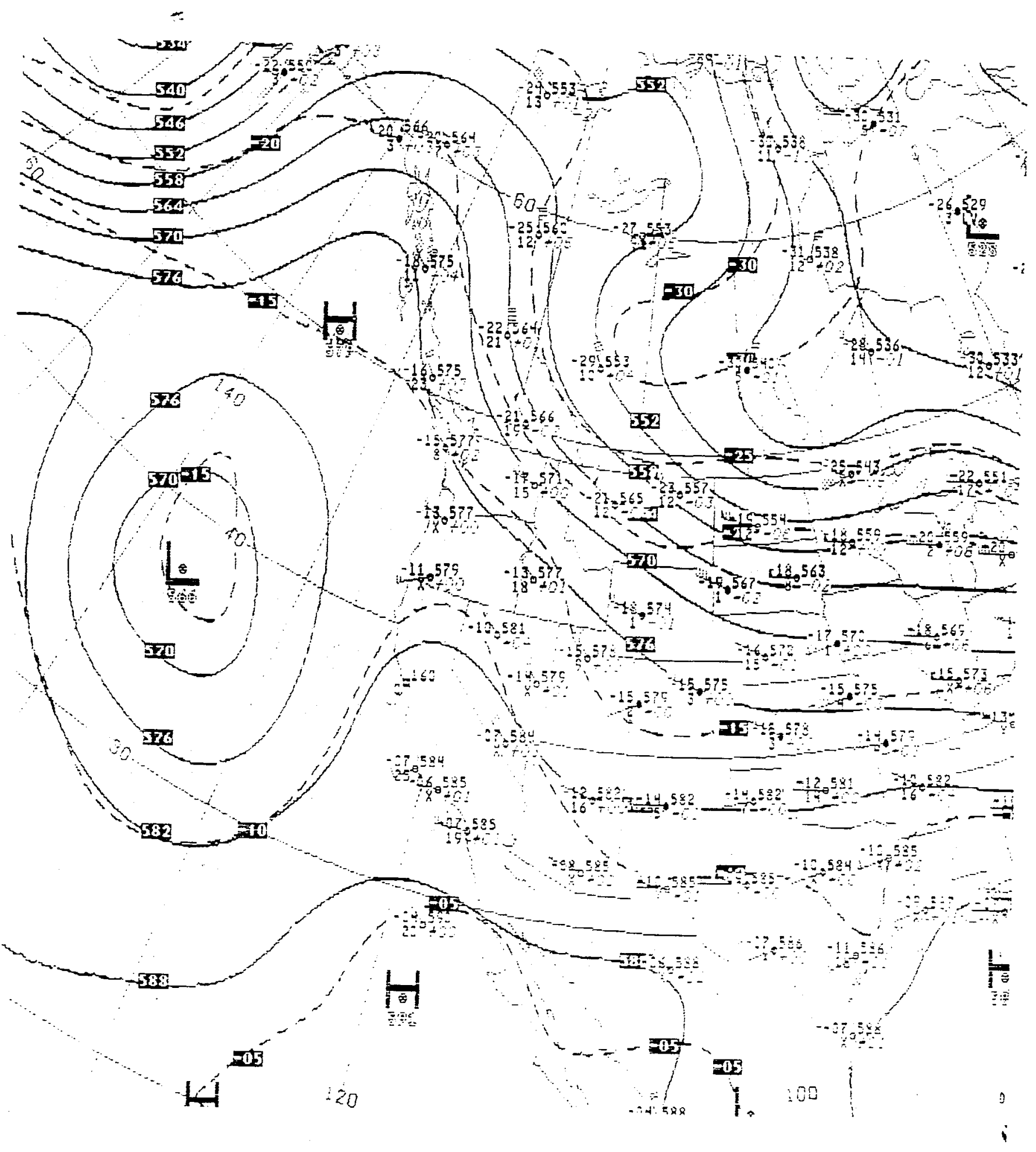

Figure A-34. 500-mb Map for October 8, 1600 PST 


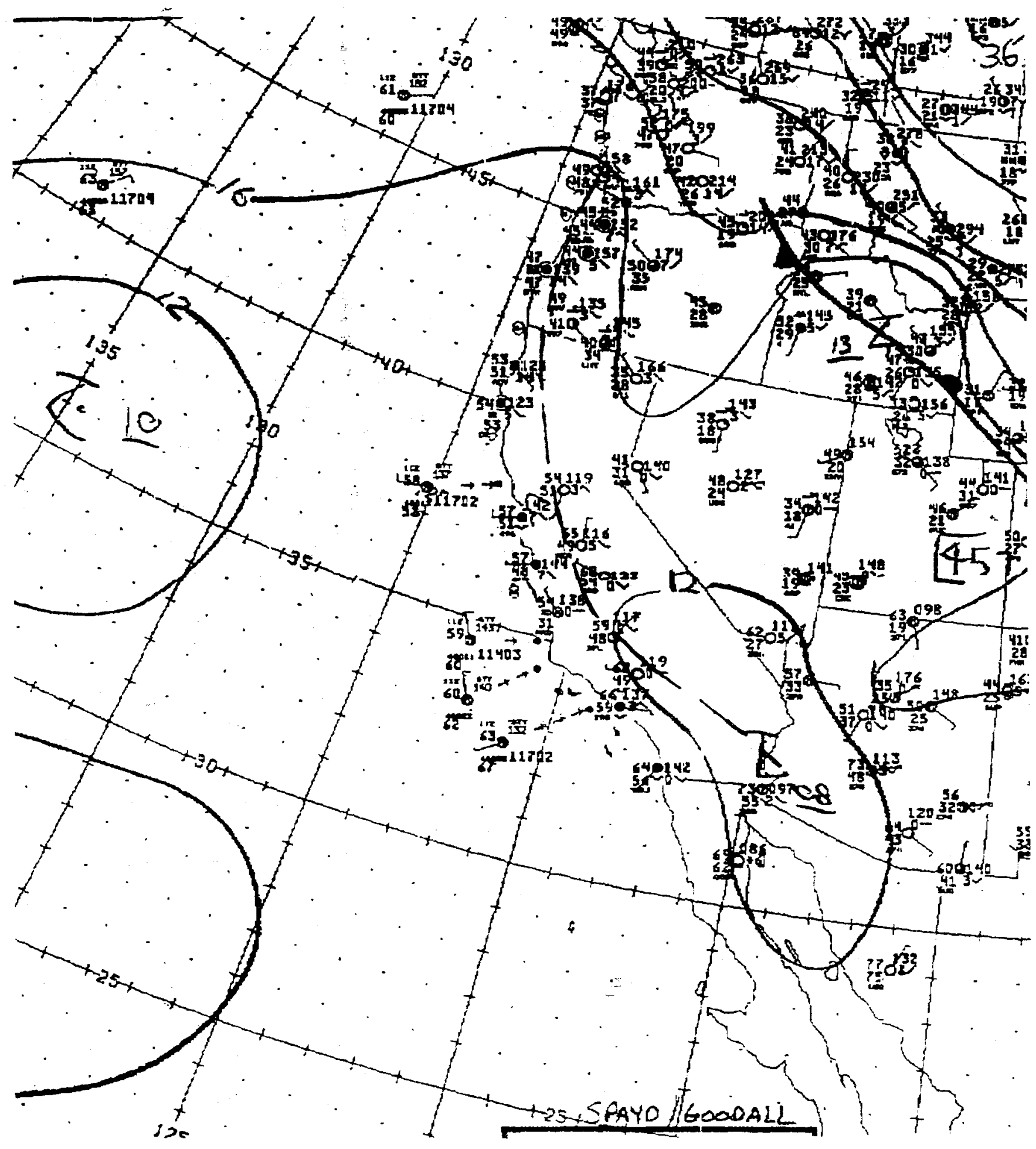

Figure A-35. Surface Weather Map for October 9, 0400 PST 


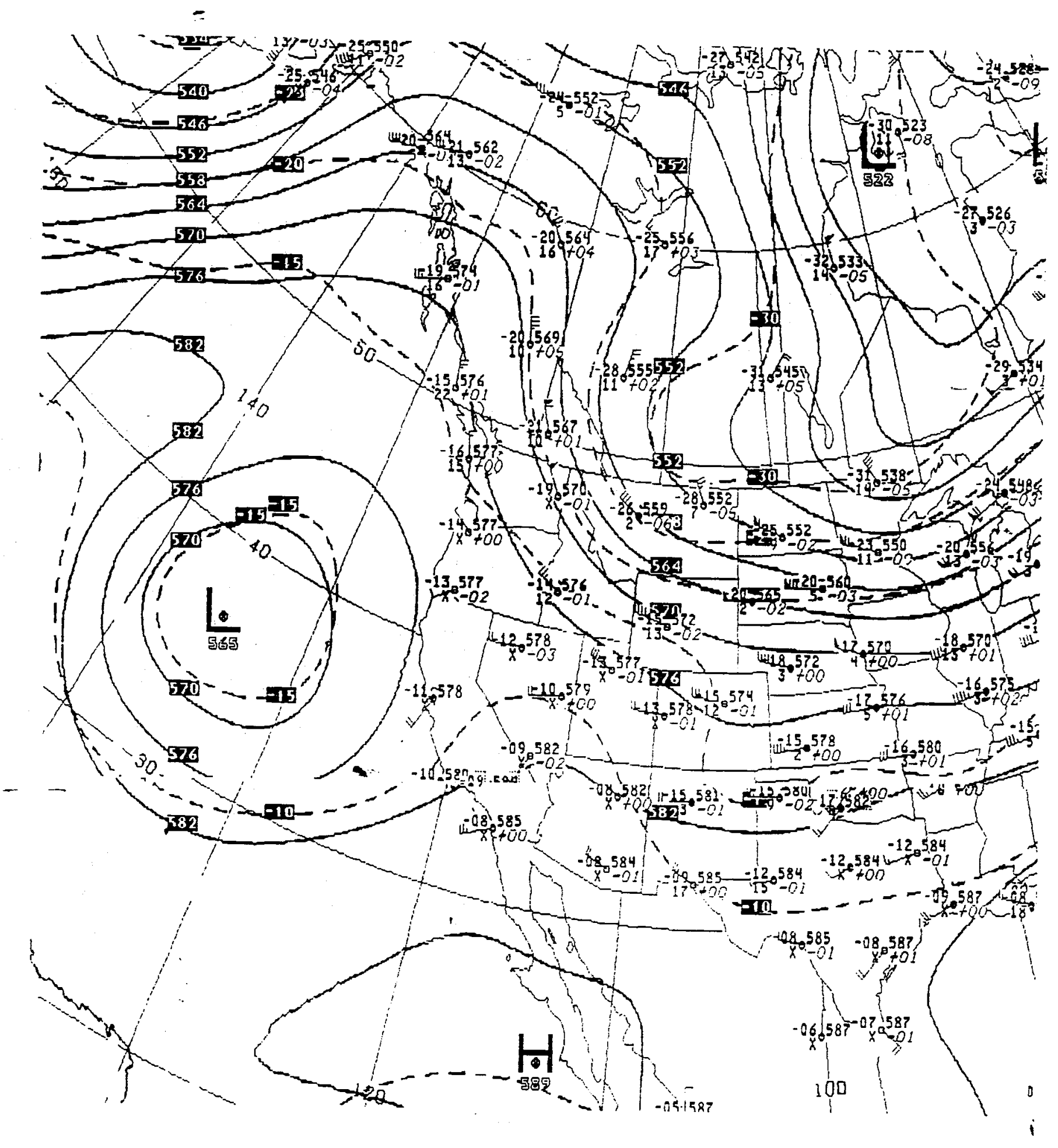

Figure A-36. 500-mb Map for October 9, 0400 PST 


\section{SEPI}

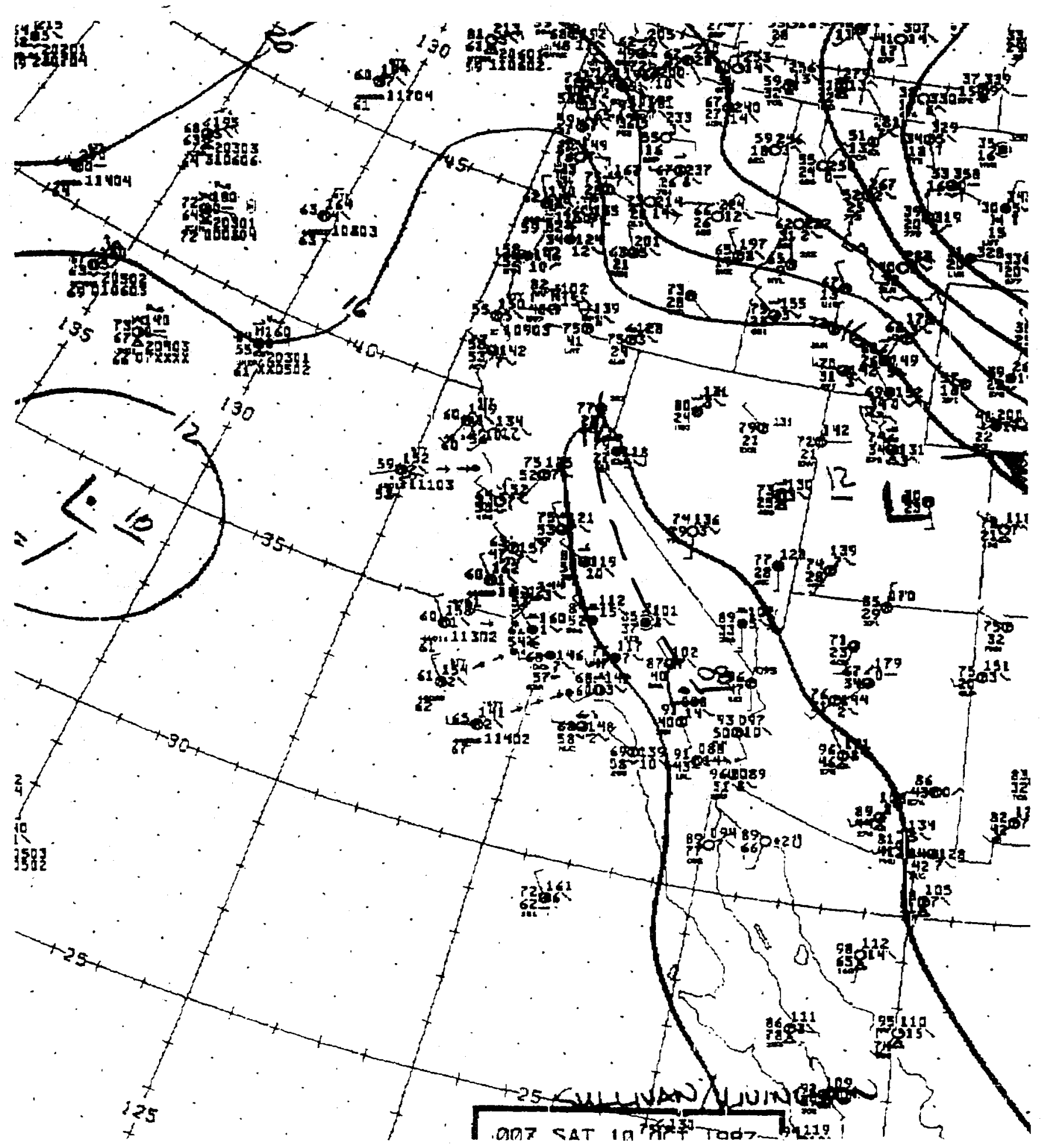

Figure A-37. Surface Weather Map for October 9, 1600 PST 


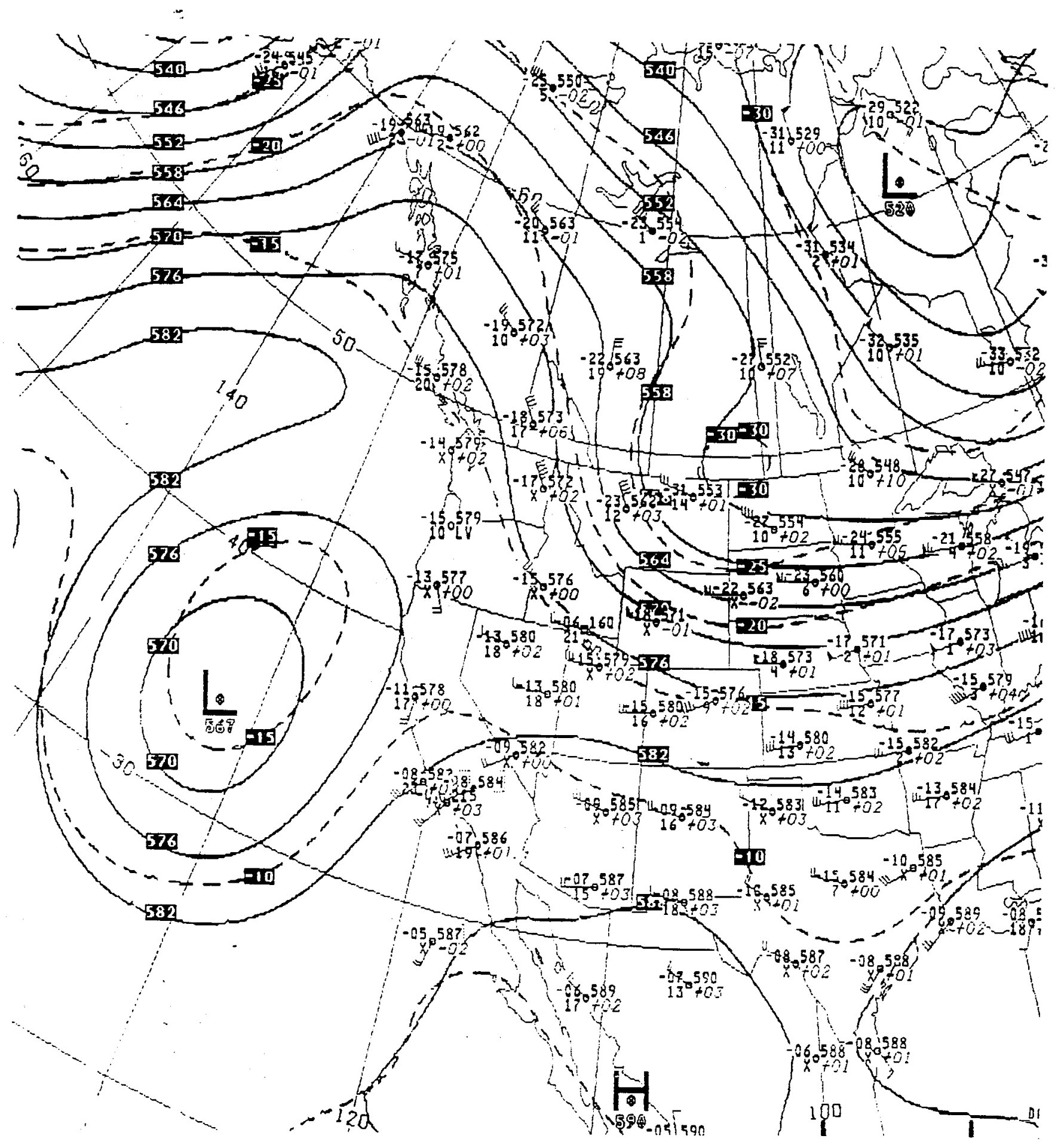

Figure A-38. 500-mb Map for October 9, 1600 PST 


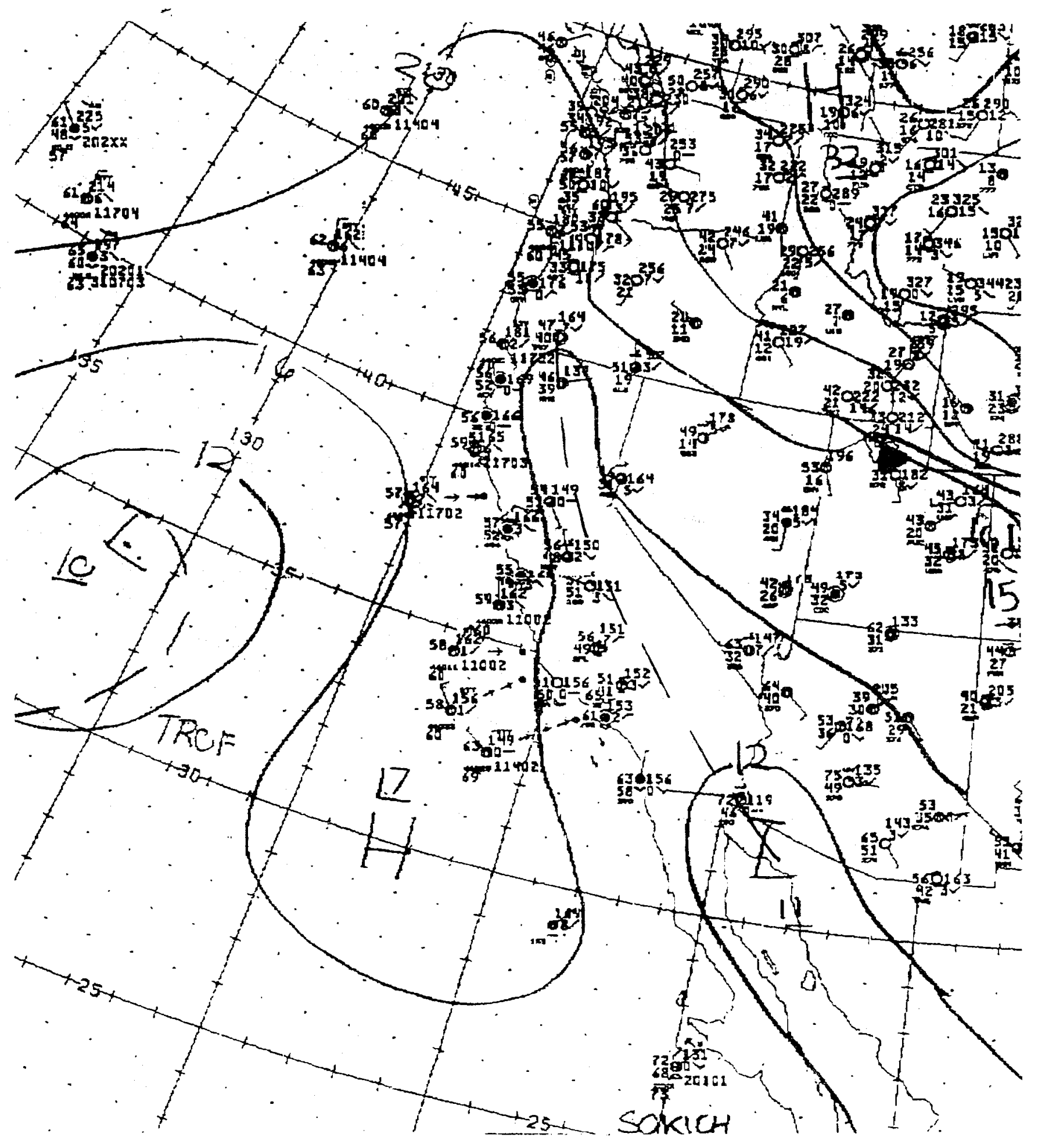

Figure A-39. Surface Weather Map for October 10, 0400 PST 


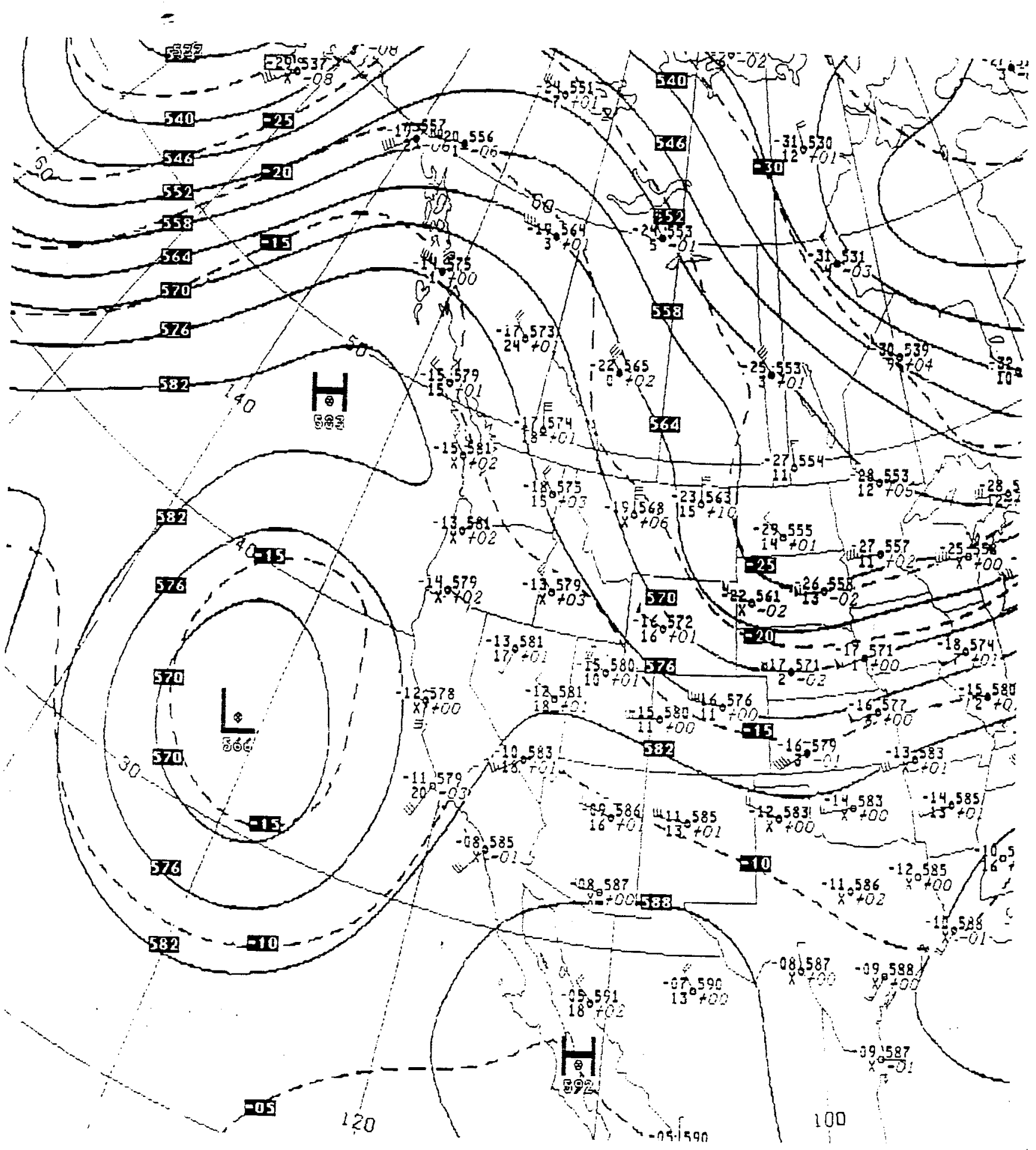

Figure A-40. 500-mb Map for October 10, 0400 PST 
APPENDIX B

Anemometer Calibrations 
TABLE B1

TABLE OF CALIBRATED ANEMOMETERS

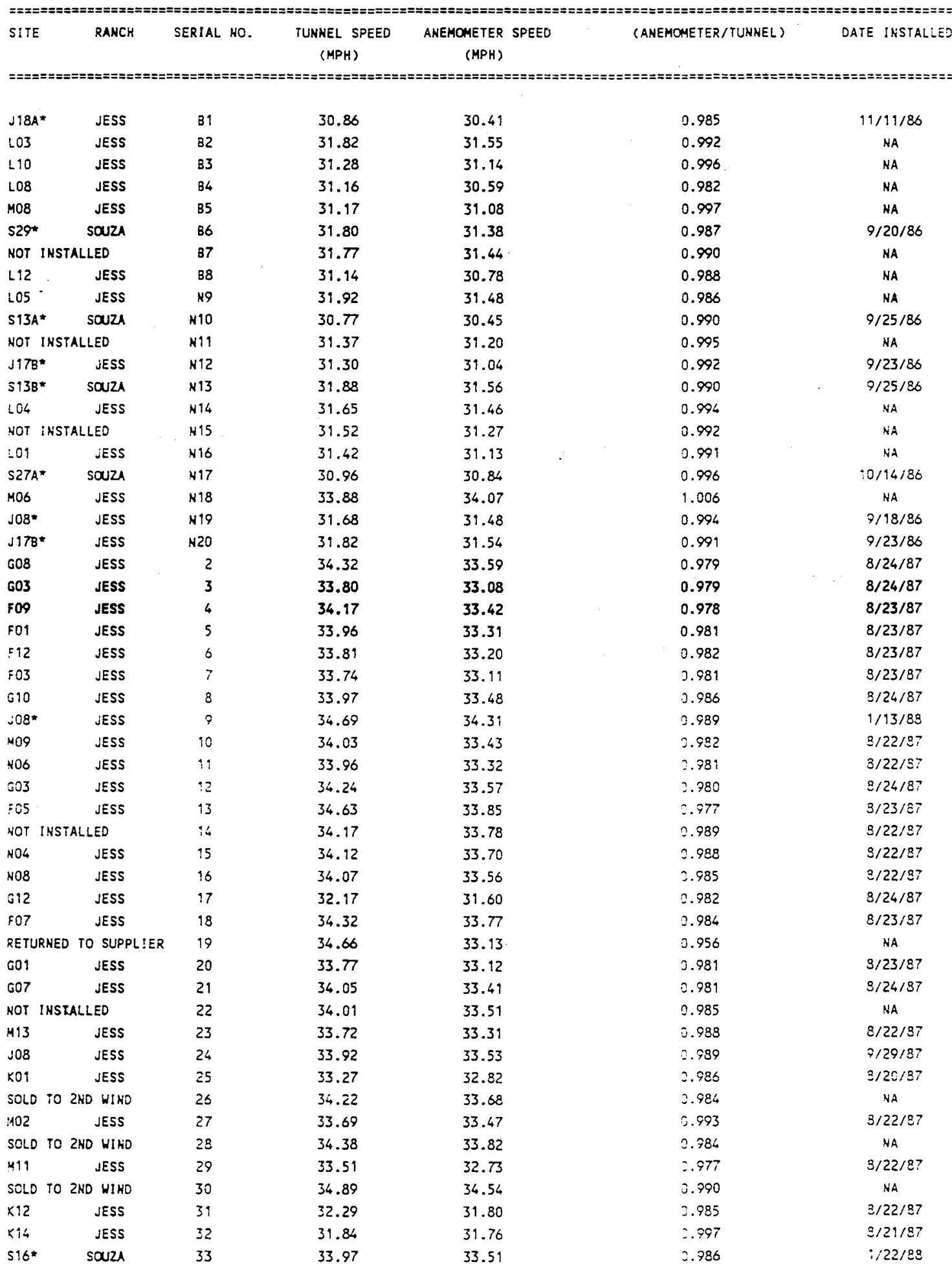




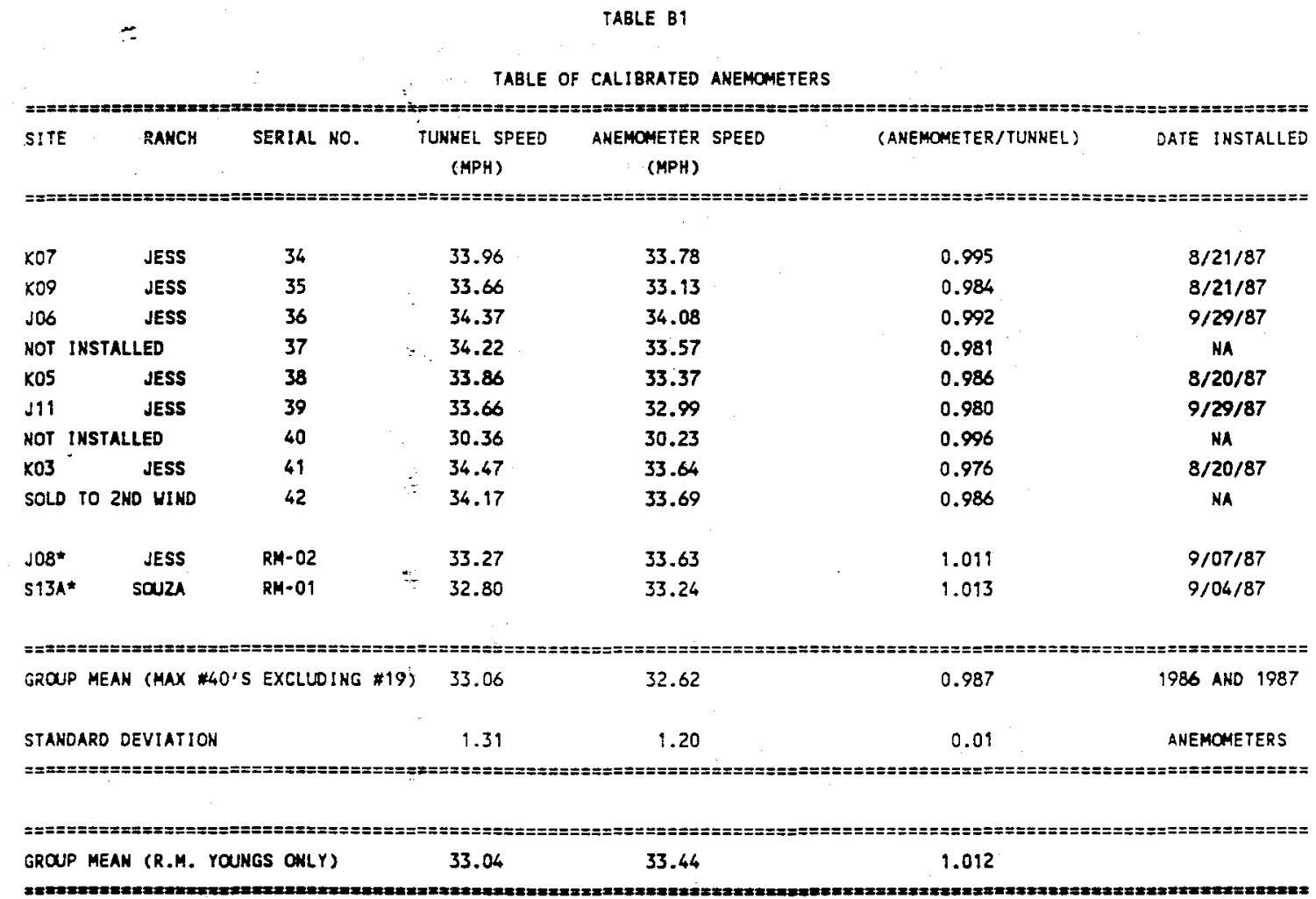

- The alphanumeric character denotes a met tower location rather than a turbine location. 
$=$

APPENDIX C

Hourly Data Listing 
HDURLY DATA LISTING

DDE FREE FLOW DATA - SDUZA RANCH

\begin{tabular}{|c|c|c|c|}
\hline ID & UNITS & DESCRIPT IDN & \\
\hline W513 & MPH & SITE $S-13$ & 70-ft reference \\
\hline WS12 & $\mathrm{MPH}$ & SITE $5-13$ & $35-p t$ \\
\hline W527 & $\mathrm{MPH}$ & S1TE $5-27$ & 80-pt reference \\
\hline WS26 & MPH & SITE $S-27$ & $45-f t$ \\
\hline WD13 & DEQ & SITE $5-13$ & $70-f t$ \\
\hline WS29 & MPH & SITE $8-29$ & $50-p t$ \\
\hline WSD2 & $\mathrm{MPH}$ & TURBINE D2 & $35-f t$ \\
\hline HBD4 & $\mathrm{MPH}$ & TURBINE D4 & $35-p t$ \\
\hline HaD6 & MPH & TURB INE DG & $35-f t$ \\
\hline WBD? & $\mathrm{MPH}$ & TURBINE D7 & $35-f t$ \\
\hline WSD 1 & $\mathrm{MPH}$ & TURBINE D11 & $35-f t$ \\
\hline WSD3 & $\mathrm{MPH}$ & TURBINE D13 & $35-f t$ \\
\hline WSE? & MPH & TURBINE EZ & $35-f t$ \\
\hline WSE 4 & $\mathrm{MPH}$ & TURBINE E4 & $35-f t$ \\
\hline WSEG & $\mathrm{MPH}$ & TURBINE EG & $35-p t$ \\
\hline
\end{tabular}

NOTES:

VALUES ARE THE 60 MINUTE AVERAGE FOR THE PERIOD ENDINO ON THE HDUR SHOWM. ALL VALUES ARE ROUNDED TO THE NEAREST DECIMAL PLACE. 
DOE FREE FLOW DATA - SOUZA RANCH

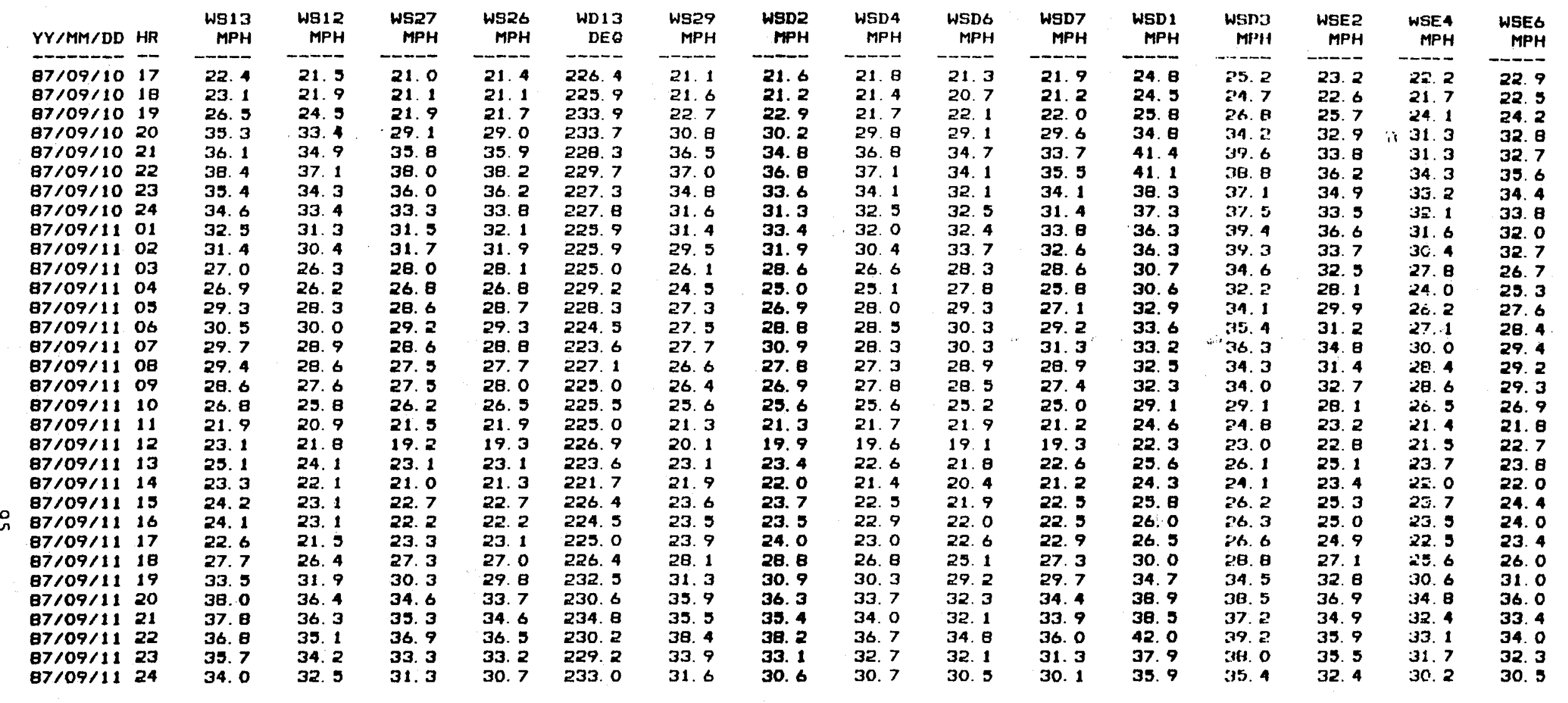


DOE FREE FLOW DATA - SOUZA RANCH

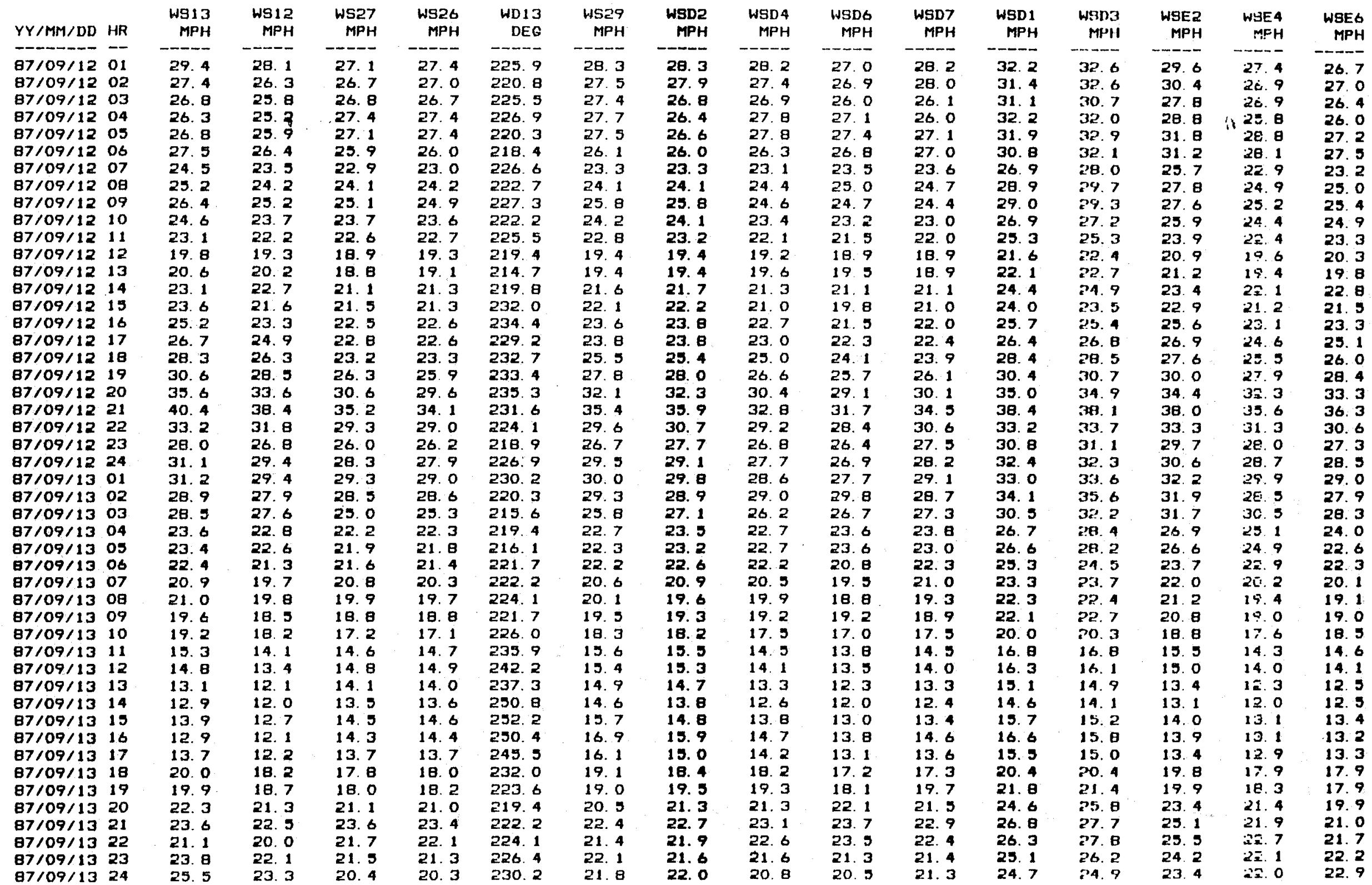


DOE FREE FLOW DATA - SOUZA RANCH

\begin{tabular}{|c|c|c|c|c|c|c|c|c|c|c|c|c|c|c|c|c|}
\hline$Y Y / M M / D D$ & HR & $\begin{array}{r}\text { WS1.3 } \\
\text { MPH }\end{array}$ & $\begin{array}{r}\text { WS12 } \\
\text { MPH }\end{array}$ & $\begin{array}{c}\text { WSE2 } \\
\text { MPH }\end{array}$ & $\begin{array}{r}\text { WS26 } \\
\text { MPH }\end{array}$ & $\begin{array}{r}\text { WD13 } \\
\text { DEG }\end{array}$ & $\begin{array}{c}\text { WSPQ } \\
\text { MPH }\end{array}$ & $\begin{array}{c}\text { WSD2 } \\
\text { MPH }\end{array}$ & $\begin{array}{r}\text { WSD4 } \\
\text { MPH }\end{array}$ & $\begin{array}{c}\text { WSDG } \\
\text { MPH }\end{array}$ & $\begin{array}{r}\text { WSD7 } \\
\text { MPH }\end{array}$ & $\begin{array}{r}\text { WSD1 } \\
\text { MPH }\end{array}$ & $\begin{array}{l}\text { WSills } \\
\text { MPHI }\end{array}$ & $\begin{array}{r}\text { WSE2 } \\
\text { MPH }\end{array}$ & $\begin{array}{r}\text { WSE4 } \\
\text { MPH }\end{array}$ & $\begin{array}{r}\text { WSEG } \\
\text { MPH }\end{array}$ \\
\hline $97 / 09 / 14$ & 01 & 25.0 & 23. 4 & 23. 6 & 23.5 & 224.5 & 24.5 & 24. 5 & 24.1 & 23. 6 & 24.5 & 27.9 & $\because \%$ & 24.6 & $2 \bar{x} 9$ & 223 \\
\hline $87 / 09 / 14$ & 02 & 20.1 & 19. 3 & 19.9 & 19.9 & 211.9 & 20.8 & 20. $\mathrm{\theta}$ & 21.1 & 20.3 & 21.2 & 24.2 & PA. 3 & 22.1 & 26.4 & 19.9 \\
\hline $87 / 09 / 14$ & 03 & 19.7 & 18. 5 & 18.4 & 18. 2 & 224.1 & 19.2 & 19. 5 & 18. 6 & 18.3 & 18. 9 & 21.8 & $\because 3$ & 20.5 & 169 & 18. \\
\hline $87 / 09 / 14$ & 04 & 21.4 & 20. 1 & 20.5 & 20. 2 & $227 . \mathrm{B}$ & 20.7 & 20.7 & 20.1 & 19.5 & 20. 7 & 23. 1 & 20. 1 & 21. 2 & 15.3 & 20. 1 \\
\hline $87 / 09 / 14$ & 05 & 1日. $\theta$ & 17.7 & 19.6 & 19. 3 & 222.7 & 20.0 & 19.3 & 19. 6 & 19.5 & 19. 3 & 22. 8 & 23.2 & $20 . \theta$ & .187 & 10.8 \\
\hline $87 / 09 / 14$ & $O B$ & 19.0 & 18.0 & 19.2 & 18. 8 & 225. 2 & 19.4 & 19.3 & 18.6 & 17.9 & 19.3 & 21.5 & 21.2 & $18 . \theta$ & 17.8 & 18. 1 \\
\hline $87 / 09 / 14$ & 07 & 19.9 & 18. 4 & 17.0 & 16. 5 & 231. 1 & 17.7 & 17. $\theta$ & 16. 8 & 16. 2 & 16. 9 & 19.4 & 19.9 & 18. 9 & 17.6 & 17.9 \\
\hline $87 / 09 / 14$ & $0 B$ & 19.3 & 17.7 & 16. 3 & 15. 8 & 229.7 & 16.7 & 16. 8 & 15.8 & 14. 8 & 16. 3 & 17.9 & 17.9 & 17.4 & 10.2 & 16. 7 \\
\hline $87 / 09 / 14$ & 09 & 18. 9 & 17.4 & 17.2 & 17. 1 & 231.6 & 17.7 & 17.7 & 16. 9 & 16. 3 & 17. 2 & 19.4 & 19.5 & 18. 8 & 17.5 & 18. 1 \\
\hline $87 / 09 / 14$ & 10 & 19. 7 & 17.9 & 17.4 & 17.5 & 234.4 & 18. 2 & 18. 2 & 17. 2 & 16. 1 & 17. 1 & 19. 3 & 19. 8 & 19.1 & 17.9 & 18. 1 \\
\hline $87 / 09 / 14$ & 11 & 18. 1 & 17.0 & 16. 6 & 16. 7 & 228. 3 & 16. 9 & 17.1 & 16. 8 & 15. 6 & 16. 3 & 18. 3 & 18. 6 & 17.9 & 10.9 & 17.6 \\
\hline $87 / 09 / 14$ & 12 & 15.7 & 15. 3 & 14.3 & 14.6 & 219.8 & 14. 3 & 14.6 & 14. 1 & 14.0 & 13. 9 & 15. 8 & 16.3 & 15.7 & 14.6 & 15. 3 \\
\hline $87 / 09 / 14$ & 13 & 14.4 & 13. 9 & 13. 7 & 14. 0 & 220.3 & 13.9 & 13. 9 & 13. 7 & 13.0 & 13. 1 & 15. 2 & 15.2 & 14.9 & 13.6 & 13. 8 \\
\hline $87 / 09 / 14$ & 14 & 15. 9 & 15.0 & 15. 4 & 15. 5 & 230.6 & 15. 9 & 16. 2 & 15. 3 & 14.8 & 15. 4 & 17. 2 & 17.5 & 16. 4 & 15. 3 & 15. 5 \\
\hline
\end{tabular}


HOURLY DATA LISTING

DOE FREE FLOW DATA - SOUZA RANCH

\begin{tabular}{|c|c|c|c|c|}
\hline ID & UNITS & DESCR IP & TION & \\
\hline WSEO & $\mathrm{MPH}$ & TURB INE & E10 & $35-p t$ \\
\hline WEE 1 & $\mathrm{MPH}$ & TURB INE & E12 & $35-f t$ \\
\hline WSE3 & $\mathrm{MPH}$ & TURB INE & E14 & $35-f t$ \\
\hline WSF2 & $\mathrm{MPH}$ & TURB INE & $\mathbf{F 2}$ & $35-f t$ \\
\hline WSF 4 & $\mathrm{MPH}$ & TURB I NE & F4 & $35-f t$ \\
\hline WSFb & MPH & TURB INE & Fo & $35-f_{t}$ \\
\hline WBFB & $\mathrm{MPH}$ & TURB INE & FB & $35-p t$ \\
\hline WSFO & MPH & TURB I NE & F10 & $35-f t$ \\
\hline WSF 1 & $\mathrm{MPH}$ & TURB INE & F12 & $35-f t$ \\
\hline WSF 3 & $\mathrm{MPH}$ & TURB I INE & F14 & $35-f t$ \\
\hline WSG2 & $\mathrm{MPH}$ & TURB INE & 02 & $35-f t$ \\
\hline W5G4 & MPH & TURB INE & 64 & $35-f t$ \\
\hline WS67 & $\mathrm{MPH}$ & TURB INE & 07 & $35-f t$ \\
\hline & $\mathrm{MPH}$ & TURB INE & 89 & $-f t$ \\
\hline
\end{tabular}

NOTES:

VALUES ARE THE GO MINUTE AVERAGE FOR THE PERIOD ENDINO ON THE HOUR SHOWN. ALL VALUES ARE ROUNDED TO THE NEAREST DECIMAL PLACE.

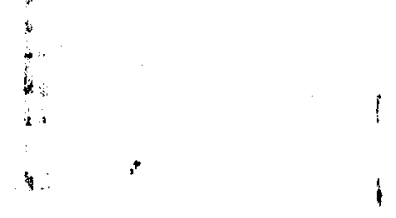


DOE FREE FLOW DATA - SOUZA RANCH

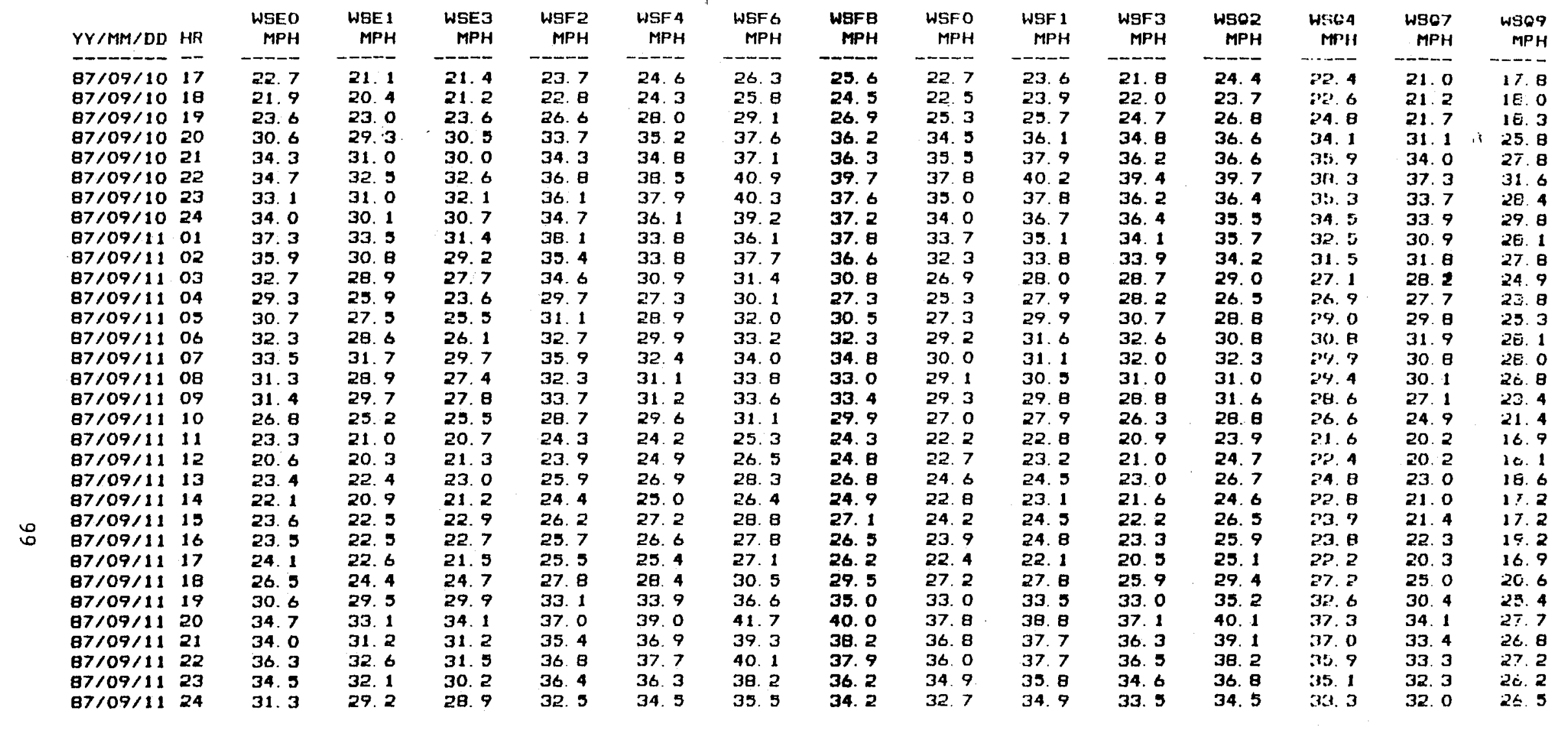


DOE FREE FLOW DATA - SDUZA RANCH

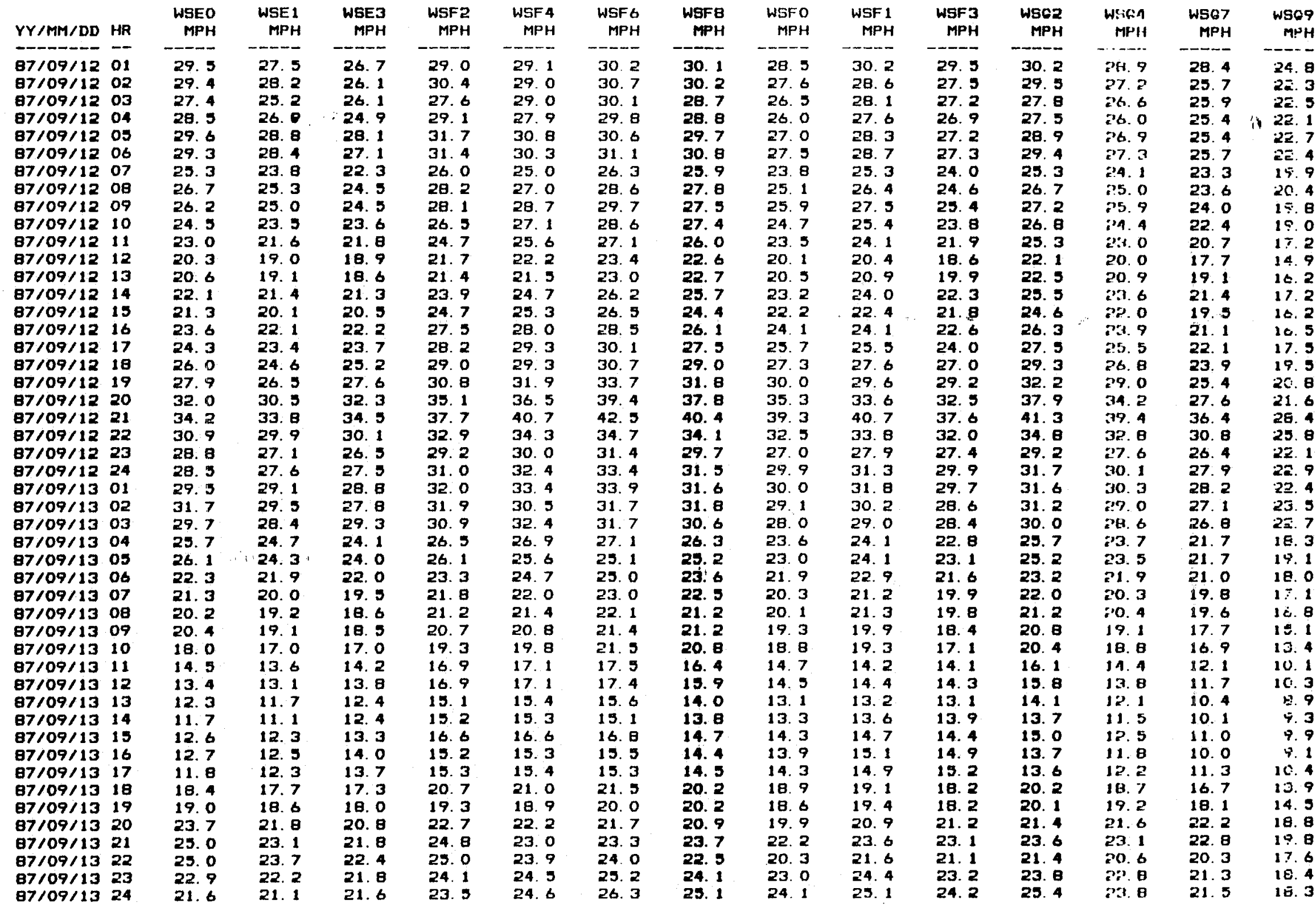


DOE FREE FLOW DATA - SOUZA RANCH

\begin{tabular}{|c|c|c|c|c|c|c|c|c|c|c|c|c|c|c|c|}
\hline$Y Y / M M / D D$ & HA & $\begin{array}{r}\text { WSEO } \\
\text { MPH }\end{array}$ & $\begin{array}{l}\text { WSE 1 } \\
\text { MPH }\end{array}$ & $\begin{array}{l}\text { WSE3 } \\
\text { MPH }\end{array}$ & $\begin{array}{r}\text { WSFZ } \\
\text { MPH }\end{array}$ & $\begin{array}{r}\text { WSF } 4 \\
\mathrm{MPH}\end{array}$ & $\begin{array}{r}\text { WSFG } \\
\text { MPH }\end{array}$ & $\begin{array}{r}\text { WSFB } \\
\text { MPH }\end{array}$ & $\begin{array}{r}\text { WSFO } \\
\text { MPH }\end{array}$ & $\begin{array}{c}\text { WSF I } \\
\text { MPH }\end{array}$ & $\begin{array}{r}\text { WBF3 } \\
\text { MPH }\end{array}$ & $\begin{array}{l}\text { WSG2 } \\
\text { MPH }\end{array}$ & $\begin{array}{l}\text { WEiG4 } \\
\text { MrHI }\end{array}$ & $\begin{array}{r}\text { WSG7 } \\
\text { MPH }\end{array}$ & $\begin{array}{l}\text { WSEO } \\
\text { MPH }\end{array}$ \\
\hline $87 / 09 / 14$ & $\begin{array}{l}01 \\
02\end{array}$ & 25.0 & $\begin{array}{l}22.8 \\
20.4\end{array}$ & $\begin{array}{l}22.1 \\
20.0\end{array}$ & 24. 2 & 24. 8 & 25. 2 & 24. 3 & 23. 0 & 24. 1 & 23. 2 & 25.0 & $\because: 4.0$ & 23. 0 & 14.6 \\
\hline $87 / 09 / 14$ & 03 & 19.7 & 18. 6 & $\begin{array}{l}20.0 \\
18.3\end{array}$ & $\begin{array}{l}21.3 \\
20.1\end{array}$ & $\begin{array}{l}21.6 \\
20.6\end{array}$ & $\begin{array}{l}21.4 \\
21.3\end{array}$ & $\begin{array}{l}21.0 \\
19.9\end{array}$ & $\begin{array}{l}19.2 \\
18.4\end{array}$ & $\begin{array}{l}20.3 \\
19.6\end{array}$ & $\begin{array}{l}19.9 \\
18.9\end{array}$ & $\begin{array}{l}20.4 \\
19.4\end{array}$ & $\begin{array}{l}19.9 \\
10.9\end{array}$ & $\begin{array}{l}19.3 \\
18.3\end{array}$ & $\begin{array}{l}18.7 \\
1=5\end{array}$ \\
\hline $87 / 09 / 14$ & 04 & 20.3 & 19. 4 & 18. 8 & 21.3 & 21.6 & 23. 0 & 22. 4 & 20.6 & 21.4 & 20. 3 & 22.0 & 0.8 & 19.1 & 15.8 \\
\hline $87 / 09 / 14$ & 05 & 20.3 & 19.1 & 18. 1 & 20.9 & 20.4 & 21.6 & 20. 5 & 18. 7 & 19.4 & 18.0 & 20.0 & 1日. 3 & 17. 0 & $\because 14.1$ \\
\hline $87 / 09 / 14$ & 06 & 18. 6 & 17. 0 & 17. 1 & 18. $\mathrm{B}$ & 19.7 & 21.2 & 20. 1 & 18. 4 & 19.3 & 17. $\mathrm{B}$ & 19.6 & 1ค. 5 & 17. 8 & 13. 1 \\
\hline $87 / 09 / 14$ & 07 & 17.2 & 16. 9 & 17. 1 & 18. 9 & 20. 2 & 21. 1 & 19. 9 & 19. 0 & 19.4 & 17. 8 & 19.9 & 1H. B & 17. 3 & 13. 9 \\
\hline $87 / 09 / 14$ & 08 & 15. $\theta$ & 15. 5 & 15. 9 & 17.7 & 18. 3 & 19.6 & 18. 9 & 18. 4 & 18. 8 & 17.4 & 19. 3 & $1 H .2$ & 16.7 & 13. 4 \\
\hline $87 / 09 / 14$ & 09 & 17. 4 & 16. 4 & 16.9 & 19. 0 & 20.2 & 21.3 & 19. 7 & 18. 3 & 18. 6 & 16. 9 & 19. 5 & 17.9 & 16. 3 & 12.9 \\
\hline $87 / 09 / 14$ & 10 & 17.4 & 16.8 & 17.5 & 20.2 & 20.8 & 22.0 & 20. 3 & 18. 7 & 18. 7 & 18. 0 & 20.1 & 18. 3 & 16. 1 & 13.8 \\
\hline $87 / 09 / 14$ & 11 & 17.0 & 15. 8 & 16. 4 & 18. 9 & 19.6 & 20.7 & 19.6 & 17. 8 & 18. 1 & 16. 6 & 19.4 & 17. 7 & 16.0 & 17.8 \\
\hline $87 / 09 / 14$ & 12 & 15.0 & 13. 6 & 13. 9 & 16. 4 & 17.0 & 17.9 & 17.3 & 15.6 & 15. 4 & 14. 1 & 17.4 & 15.9 & 14. 3 & 11.9 \\
\hline $87 / 09 / 14$ & 13 & 14. 1 & 12. 5 & 13. 0 & 15. 9 & 16. 1 & 16. 5 & 15. 7 & 14. 1 & 13. 7 & 13.6 & 15. 7 & 14.5 & 12. 4 & 1C. 2 \\
\hline $87 / 09 / 14$ & 14 & 15.3 & 14. 2 & 14.5 & 17.3 & 17.9 & 18. 6 & 17.4 & 15.7 & 15. 4 & 14. $\theta$ & 17.3 & 15.7 & 13. 3 & 11.2 \\
\hline
\end{tabular}


HOURLY DATA LISTING

DOE FREE FLOW DATA - JESS RANCH

\begin{tabular}{|c|c|c|c|}
\hline ID & UNITS & DESCRIPTID & \\
\hline WSOB & $\mathrm{MPH}$ & SITE $J-O B$ & 50-ft reference \\
\hline WDOB & DEG & SITE J-OB & DIRECTION \\
\hline WS 14 & MPH & SITE $\checkmark-04$ & 120-ft reference \\
\hline WS15 & MPH & SITE J-19 & 40-ft level \\
\hline WS16 & MPH & SITE $\quad J-17$ & 35-ft level \\
\hline WS17 & MPH & SITE $\cup-17$ & 70-ft tower \\
\hline WS18 & MPH & SITE $U-18$ & 35-ft level \\
\hline W519 & MPH & SITE $J-18$ & 70-ft tower \\
\hline TTO1 & DEG F & TEMPERATUR & \\
\hline WSC 1 & $\mathrm{MPH}$ & TURBINE C1 & $50-f t$ \\
\hline WSC 3 & MPH & TURBINE C3 & $50-f t$ \\
\hline WSCS & $\mathrm{MPH}$ & TURBINE C5 & $50-f t$ \\
\hline WSC 7 & $\mathrm{MPH}$ & TURBINE C7 & $50-f t$ \\
\hline WSE9 & MPH & TURBINE CO & $50-f t$ \\
\hline WSC? & $\mathrm{MPH}$ & TURBINE CI & $50-f t$ \\
\hline
\end{tabular}

NOTES:

VALUES ARE THE GO MINUTE AVERAGE FOR THE PERIOD ENDING ON THE HOUR SHOWK ALL VALUES ARE ROUNDED TO THE NEAREST DECIMAL PLACE. 
DDE FREE FLOW DATA - JESS RANCH

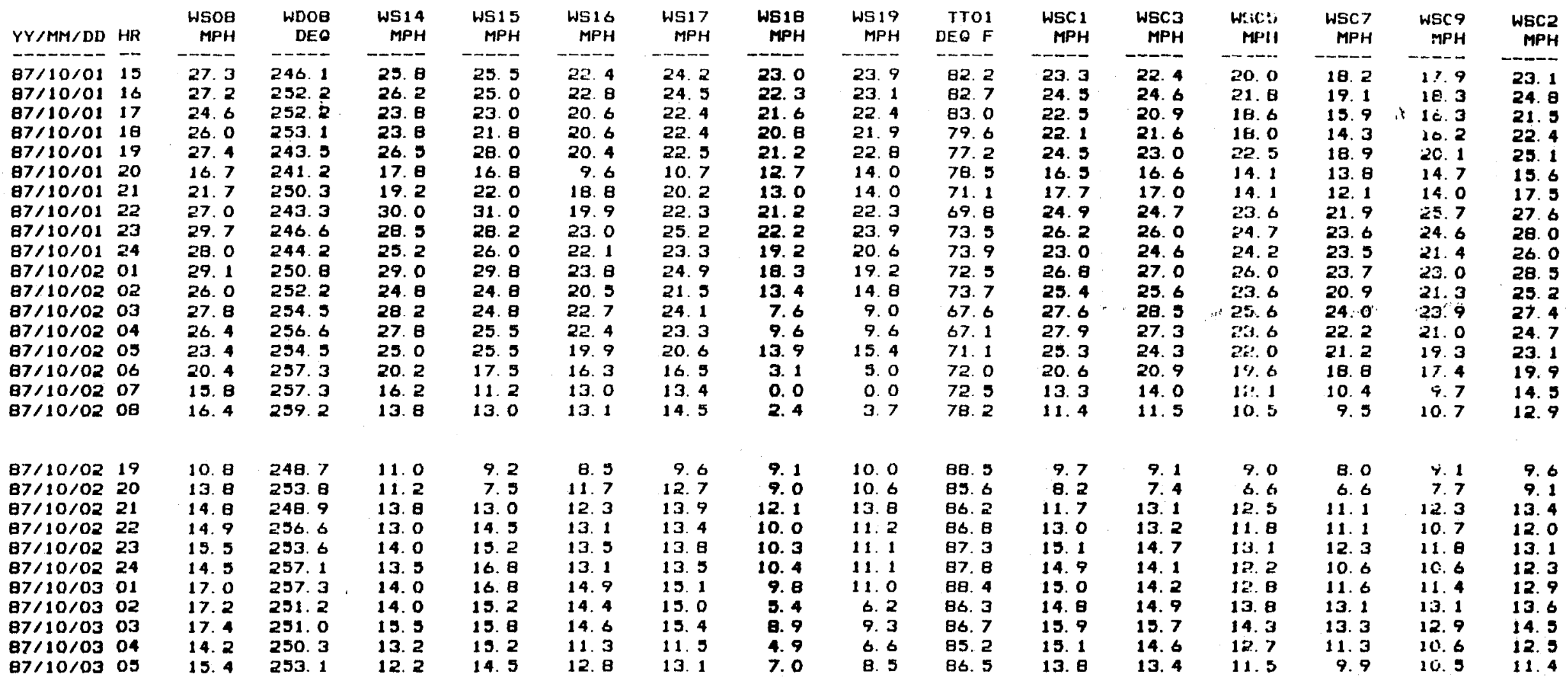


DOE FREE FLOW DATA - JESS RANCH

\begin{tabular}{|c|c|c|c|c|c|c|c|c|c|c|c|c|c|c|c|c|}
\hline$Y Y / M M / D D$ & $H R$ & $\begin{array}{c}\text { WSOB } \\
\text { MPH }\end{array}$ & $\begin{array}{r}\text { WDOB } \\
\text { DEC }\end{array}$ & $\begin{array}{c}\text { WS14 } \\
\text { MPH }\end{array}$ & $\begin{array}{c}\text { WS1S } \\
\text { MPH }\end{array}$ & $\begin{array}{r}\text { WS1 } 6 \\
\text { MPH }\end{array}$ & $\begin{array}{l}\text { WS17 } \\
\text { MPH }\end{array}$ & $\begin{array}{c}\text { WS1B } \\
\text { MPH }\end{array}$ & $\begin{array}{r}\text { WS19 } \\
\text { MPH }\end{array}$ & $\begin{array}{l}\text { Tro1 } \\
\text { DEG F }\end{array}$ & $\begin{array}{c}\text { WSC } 1 \\
\text { MPH }\end{array}$ & $\begin{array}{c}\text { WSC. } \\
\text { MPH }\end{array}$ & $\begin{array}{c}\text { HSCS } \\
\text { MPH }\end{array}$ & $\begin{array}{r}\text { WSC7 } \\
\mathrm{MPH}\end{array}$ & $\begin{array}{r}\text { WSC9 } \\
\text { MPH }\end{array}$ & $\begin{array}{r}\text { WSC2 } \\
\text { MPH }\end{array}$ \\
\hline $87 / 10 / 07$ & 09 & 29.1 & 243. 0 & 32. $\mathrm{B}$ & 17. 8 & 14. 2 & 15. 2 & 17. 0 & 19. 0 & 01.9 & 27.9 & 27.4 & 22.7 & 20. 5 & 16.9 & 28. 9 \\
\hline $87 / 10 / 07$ & 10 & 35. 1 & 250.4 & 35. 0 & 33. 0 & 25. 5 & 25. 2 & 25.0 & 26.5 & 63.4 & 33. 2 & 33. 5 & 30.3 & 28. 0 & 28.5 & 33.5 \\
\hline $87 / 10 / 07$ & 11 & 33.5 & 250.1 & 32.5 & 26.0 & 24. 7 & 26.7 & 24. 5 & 26. 1 & 66. 1 & 29. 5 & 30.4 & 26.7 & 24.3 & 124.6 & 30.6 \\
\hline $87 / 10 / 07$ & 12 & 31.9 & 254. 5 & 29. 8 & 26. 2 & 24. 5 & 26.6 & 25. 0 & 26. 3 & 68.8 & 28. 3 & 27.6 & 24.7 & 22. 4 & 2E. 2 & 28. 1 \\
\hline $87 / 10 / 07$ & 13 & 29.0 & 251.5 & 25. 5 & 23. 5 & 23. 0 & 24. 9 & 21. 3 & 22. 3 & 71.5 & 23.6 & 22. 3 & 20.1 & 1日. 8 & 17.6 & 23. 1 \\
\hline $87 / 10 / 07$ & 14 & 28. 5 & 251.0 & 19. 5 & 20.5 & 22. 9 & 25. 1 & 19. $\theta$ & 20.6 & 72.9 & 19.0 & 17. 2 & 16. 4 & 16.0 & 17.0 & 18. 0 \\
\hline $87 / 10 / 07$ & 15 & 26.6 & 250.3 & 20. 8 & 21.0 & 22. 1 & 24. 2 & 20.3 & 21.1 & 74. 8 & 20.1 & 18. 0 & 16.7 & 15.7 & 16. 4 & 18. 8 \\
\hline $87 / 10 / 07$ & 16 & 27. 2 & 250.1 & 22. 8 & 20.5 & 223 & 24.3 & 21.6 & 22. 5 & 74.8 & 21.7 & 19. 8 & 1日. 4 & 17.0 & 17.0 & 21.2 \\
\hline $87 / 10 / 07$ & 17 & 25.6 & 252. 4 & 24. 0 & 23. 0 & 20.0 & 218 & 19. 9 & 20.6 & 74. 5 & 21. 9 & 20.7 & 19.7 & 18. 2 & 17.8 & 22. 1 \\
\hline $87 / 10 / 07$ & 18 & 29.6 & 245.6 & 30.0 & 27.5 & 24. 1 & 26. 1 & 24. 3 & 25.5 & 71.5 & 27.4 & 26. 1 & 4.6 & 20.1 & $\therefore 5$ & 28. 7 \\
\hline $87 / 10 / 07$ & 19 & 34.1 & 250. 5 & 34. $\mathrm{B}$ & 32.5 & 29.0 & 31.5 & 27.4 & 28.9 & 6. 3 & 31.9 & 30. 1 & 5.3 & 22. 7 & 26.8 & 33. 1 \\
\hline $87 / 10 / 07$ & 20 & 38.8 & 248.7 & 36.8 & 32. 2 & 32. 5 & 35. 1 & 31.5 & 32.8 & 61.8 & 33. 6 & 34. 1 & 31.7 & $2 \theta .3$ & 27.9 & 36.0 \\
\hline $87 / 10 / 07$ & 21 & 37.7 & 249.6 & 38.8 & 36.5 & 30.6 & 33. 5 & 27.7 & 29.0 & 59.8 & 36. 3 & 36.6 & 33.2 & 30.0 & $3 \pi \cdot 2$ & 36.5 \\
\hline $87 / 10 / 07$ & 22 & 36.3 & 250.1 & 37.2 & 37.8 & 29.4 & 32. 3 & $2 \theta .7$ & 30.5 & 59.3 & 33. 7 & 35. 6 & 33. 1 & 30. 8 & 32.3 & 36. 2 \\
\hline $87 / 10 / 07$ & 23 & 37.4 & 248. 2 & 3日. 5 & 39.5 & 30.6 & 33. 2 & 29. 2 & 31.5 & 59.1 & 35. 1 & 36. 9 & $3 \% .4$ & 30.5 & 34.6 & 37. 1 \\
\hline $87 / 10 / 07$ & 24 & 35. 9 & 244. 2 & 3日. 0 & 37. 5 & 30.1 & 33. 1 & 26.7 & 20.9 & 5日. 8 & 32. 7 & 36.1 & 32. 5 & 29.0 & 32. 3 & 35.6 \\
\hline $87 / 10 / 08$ & 01 & 33. 3 & 244. 2 & 33. 1 & 34.5 & 26.4 & 28.7 & 24. 1 & 26. 1 & 59. 1 & 31.4 & 32. 1 & 30. 1 & 27. 3 & $3 C .2$ & 32.6 \\
\hline $87 / 10 / 08$ & 02 & 29.3 & 243. 7 & 31.2 & 32. 8 & 19. 5 & 20: 5 & 24. 5 & 26.9 & 58.8 & 29.6 & 30.4 & E'A. 2 & 26.0 & $2 E .5$ & 30. 2 \\
\hline $87 / 10 / 08$ & 03 & 27.0 & 241.4 & 31.0 & 322 & 18. 3 & 19. 5 & 22.7 & 25. 0 & 58. 4 & 30. 0 & 29.6 & 27.2 & 25. 2 & 28.1 & 29.4 \\
\hline $87 / 10 / 08$ & 04 & 23. 8 & 242. 8 & 32.0 & 30.2 & 18. 5 & 20. 2 & 22. 4 & 24. 4 & 58.5 & 29.8 & 30.4 & 27.0 & 25. 3 & 27.8 & 29. $\theta$ \\
\hline $87 / 10 / 08$ & 05 & 26.4 & 243. 3 & 31.5 & 30.5 & 21.2 & 22. 7 & 22. 3 & 24. 5 & 5日. 5 & 28. 7 & 28.7 & Es 5 & 23. 6 & 24.9 & 28. 4 \\
\hline $87 / 10 / 0 \theta$ & 06 & 25.8 & 245. 9 & 2日. 5 & 29.0 & 20.6 & 22. 3 & 19. 9 & 21.9 & 58. 4 & 26.4 & 26.9 & 24. 3 & 22. 1 & 23.2 & 26.8 \\
\hline $87 / 10 / 00$ & 07 & 23.2 & 247.7 & 26.5 & 28.5 & 17.9 & 18. 9 & 19.6 & 21.6 & 58. 4 & 26. 1 & 24. $\theta$ & $x^{\prime \prime} \alpha^{\prime} \cdot 6$ & 20.7 & 23.1 & 24. 7 \\
\hline $87 / 10 / 08$ & $O B$ & 21.7 & 244.9 & 26.5 & 27.0 & 18. 0 & 19. 3 & 19. 0 & 20.6 & 58.6 & 24. 8 & 25. 4 & E'? 0 & 20.4 & $20 . \theta$ & 25. 2 \\
\hline $87 / 10 / 08$ & 09 & 18. 3 & 237.2 & 26.2 & 25. 8 & 15. 6 & 16. 6 & 19. 5 & 21.3 & 59.6 & 24.5 & 25. 1 & 22.1 & 21.4 & 21.2 & 25. 1 \\
\hline $87 / 10 / 08$ & 10 & 16. 1 & 243. 5 & 20.8 & 21.8 & 13. 4 & 14. 3 & 15. 9 & 17. 2 & 62.4 & 20.3 & 19. 5 & 17.4 & 16. 4 & 10.1 & 19. 7 \\
\hline $87 / 10 / 08$ & 11 & 17. 7 & 243. 7 & 19. 2 & 19. 2 & 14. 2 & 15. 2 & 13. 9 & 14. 7 & 65.5 & 18. 4 & 17.8 & 15.6 & 14.6 & 14.3 & 17.7 \\
\hline $87 / 10 / 08$ & 12 & 18.6 & 252.7 & 1日. 8 & 18. $\theta$ & 14. $\theta$ & 15. 8 & 13.6 & 14. 3 & 68.5 & 18. 0 & 17.1 & 15. 2 & 14. 1 & 14.5 & 17. 1 \\
\hline $87 / 10 / 08$ & 13 & 20.7 & 251.3 & 19.0 & 19.0 & 16. 8 & 16. 1 & 15. 5 & 16. 2 & 70.8 & 18. 5 & 16. 8 & 15. 3 & 14. 3 & 14.7 & 17. 4 \\
\hline $87 / 10 / 08$ & 14 & $22 . \theta$ & 251.3 & 21.5 & 20.5 & 18. 4 & 19. 7 & 17. 8 & 18. 5 & 72. 2 & 20. 3 & 18. 9 & 17.7 & 15.6 & 15.8 & 19. 8 \\
\hline $87 / 10 / 08$ & 15 & 24.0 & 253. 1 & 22. 5 & 22.0 & 19. 5 & 21. 1 & 18. 2 & 19.1 & 73. 9 & 21.5 & 19.6 & 18. 4 & 16. 7 & 16.4 & 20.6 \\
\hline $87 / 10 / 08$ & 16 & 26.3 & 249.8 & 23. 2 & 22. 2 & 21.7 & 23. 5 & 20.4 & 21.3 & 72.8 & 22. 3 & 19.9 & 1H. 6 & 17. 1 & 1E. 2 & 21.1 \\
\hline $87 / 10 / 00$ & 17 & 25. 1 & 244.7 & 23. 0 & 23. 2 & 20. 3 & 21:9 & 19. 3 & 20.1 & 71.1 & 22. 0 & 20.3 & $1 \% .0$ & 17.3 & 17.5 & 21.1 \\
\hline $87 / 10 / 08$ & 18 & 23.7 & 240.0 & 23. 5 & 22. 8 & 19. 3 & 20.9 & 16. 8 & 17.7 & 69.7 & 23. 0 & 21.3 & 18.9 & 18. 0 & 17.5 & 21.2 \\
\hline $87 / 10 / 08$ & 19 & 27.5 & 246.3 & 25. 8 & 27.0 & 22.6 & 24.4 & 19. 5 & 20.8 & 65.8 & 25. 0 & 24. 8 & 2.1.5 & 19.7 & 19.9 & 23. 2 \\
\hline $87 / 10 / 08$ & 20 & 32.5 & 249. 4 & 26. 8 & 30.5 & 29. 1 & 31.3 & 24. 4 & 26.3 & 61.4 & 26. 2 & 26.0 & $=-4.8$ & 23.7 & 15.9 & 26. 7 \\
\hline $87 / 10 / 00$ & 21 & 31.5 & 247.0 & 33. 8 & 33. 2 & 28. 3 & 30.7 & 27.7 & 28. 3 & 59.2 & 31.9 & 31.2 & 29. 3 & 27.7 & $27 . \theta$ & 31.3 \\
\hline $87 / 10 / 00$ & 22 & 33. 2 & 246.8 & 32.0 & 35. 8 & 28.6 & 31. 1 & 24. 0 & 25. 3 & 5B. 4 & 33.7 & 30. $\mathrm{B}$ & 26. $B$ & 25.7 & 31.3 & 29. 9 \\
\hline$\theta 7 / 10 / 0 \theta$ & 23 & 35.7 & 249.6 & 31.2 & 32.8 & 29. 7 & 32. 5 & 28. 4 & 30.0 & 57.7 & 321 & 29.5 & 27.2 & 25. 3 & 27.6 & 29.6 \\
\hline $87 / 10 / 08$ & 24 & 34. 5 & 244.7 & 31.0 & 35. 8 & 24. 8 & 27. 4 & 23. 4 & 25.0 & 57.5 & 29.2 & 29.1 & 28.4 & 27.2 & $2 \overline{6} .4$ & 30. 7 \\
\hline
\end{tabular}


DOE FREE FLOW DATA - JESS RANCH

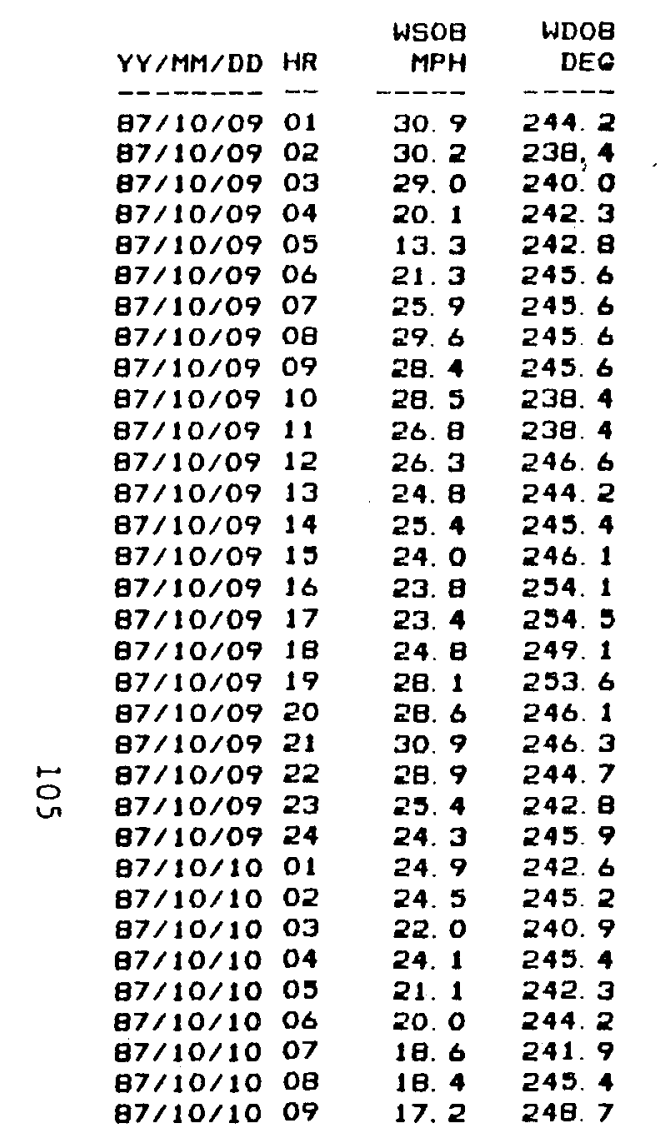

\begin{tabular}{rr} 
WS14 & WS15 \\
MPH & $M P H$ \\
\hdashline 33.2 & 35.5 \\
30.5 & 32.0 \\
31.8 & 30.2 \\
26.5 & 21.2 \\
16.8 & 14.8 \\
23.0 & 24.2 \\
25.8 & 25.0 \\
31.0 & 29.0 \\
$2 B .5$ & 29.2 \\
30.5 & 27.5 \\
29.2 & 26.0 \\
28.0 & 26.5 \\
26.2 & 24.2 \\
26.0 & 24.8 \\
24.0 & 22.8 \\
23.0 & 22.0 \\
18.0 & 17.5 \\
24.5 & 19.8 \\
24.8 & 24.0 \\
24.5 & 23.2 \\
26.8 & 26.2 \\
25.8 & 28.0 \\
26.0 & 24.0 \\
23.8 & 23.8 \\
23.5 & 24.8 \\
21.0 & 22.8 \\
17.8 & 19.0 \\
22.2 & 19.0 \\
21.5 & 18.8 \\
20.8 & 17.5 \\
20.8 & 18.5 \\
21.0 & 18.2 \\
19.8 & 16.5 \\
&
\end{tabular}

\begin{tabular}{rrrrr} 
WS16 & WS17 & WS18 & WS19 & TTO1 \\
MPH & MPH & MPH & MPH & DEG F \\
\hline 27.6 & 30.1 & 22.9 & 24.2 & 58.6 \\
26.6 & 29.0 & 23.2 & 24.4 & 57.5 \\
22.7 & 24.5 & 21.8 & 23.7 & 56.6 \\
12.9 & 13.8 & 16.9 & 18.3 & 57.2 \\
9.6 & 10.6 & 11.1 & 12.6 & 57.2 \\
16.2 & 17.7 & 17.0 & 18.5 & 56.5 \\
21.4 & 23.1 & 18.3 & 19.5 & 55.7 \\
23.8 & 26.1 & 21.1 & 22.5 & 55.7 \\
22.8 & 24.7 & 19.9 & 21.3 & 57.3 \\
23.0 & 24.7 & 21.6 & 22.8 & 58.1 \\
22.5 & 24.3 & 22.8 & 24.4 & 59.1 \\
22.5 & 24.3 & 22.0 & 23.3 & 59.9 \\
20.6 & 22.2 & 21.3 & 22.4 & 62.4 \\
20.9 & 22.6 & 20.8 & 22.0 & 63.7 \\
20.1 & 21.7 & 19.6 & 20.8 & 65.5 \\
19.0 & 20.9 & 19.0 & 20.0 & 67.1 \\
18.7 & 20.1 & 15.6 & 16.8 & 66.6 \\
18.4 & 19.8 & 15.9 & 17.2 & 66.4 \\
22.2 & 24.0 & 19.3 & 20.9 & 63.5 \\
23.8 & 26.0 & 20.5 & 22.0 & 60.5 \\
25.6 & 27.7 & 22.6 & 24.1 & 58.7 \\
23.7 & 25.6 & 21.9 & 23.3 & 57.9 \\
20.3 & 22.0 & 18.3 & 19.6 & 57.4 \\
19.4 & 21.0 & 17.6 & 19.0 & 57.3 \\
19.5 & 21.4 & 17.6 & 19.1 & 57.0 \\
19.7 & 21.5 & 15.6 & 16.7 & 57.1 \\
15.5 & 17.2 & 11.3 & 12.3 & 57.0 \\
18.9 & 20.8 & 15.0 & 16.1 & 56.7 \\
15.4 & 17.1 & 15.1 & 16.3 & 57.0 \\
15.8 & 17.4 & 13.9 & 15.2 & 57.1 \\
13.1 & 14.9 & 13.8 & 15.3 & 57.1 \\
13.8 & 19.1 & 13.6 & 15.0 & 57.0 \\
12.9 & 13.8 & 12.6 & 13.7 & 58.4
\end{tabular}

\begin{tabular}{|c|c|c|}
\hline $\begin{array}{c}\text { WSC } 1 \\
\text { MPH }\end{array}$ & $\begin{array}{r}\text { WSC3 } \\
\text { MPH }\end{array}$ & $\begin{array}{c}\text { WEic.s } \\
\text { MPH }\end{array}$ \\
\hline 30. 9 & 30. 5 & 2A. 7 \\
\hline 29.7 & 29. 2 & 25. 5 \\
\hline 30. 0 & 30.7 & 27.2 \\
\hline 25. $B$ & 25. 7 & 23.0 \\
\hline 16.0 & 15. 5 & 1:3. 7 \\
\hline 21.6 & 21.1 & IH. 8 \\
\hline 24.0 & 22. 4 & 19. 7 \\
\hline 27.4 & 27.6 & $: 4.1$ \\
\hline 26.7 & 26. 9 & 23. 4 \\
\hline 28. 5 & 28. 0 & 24. 9 \\
\hline 27.6 & 26. 3 & $\because 4.4$ \\
\hline 26. 1 & 25. 3 & 4 ג'ון \\
\hline 24.9 & 23. 8 & 22.0 \\
\hline 24. 5 & 23.6 & 21.8 \\
\hline 22. 5 & 21.3 & 19.0 \\
\hline 21. 8 & 20. 2 & 19.0 \\
\hline 16.9 & 15.4 & 14.2 \\
\hline 21.5 & 22.4 & 20.0 \\
\hline 23. 8 & 22. 3 & $20 . \theta$ \\
\hline 23. 0 & 21.7 & 19. 9 \\
\hline 25. 1 & 23. 4 & 21. 6 \\
\hline 24. 5 & 23. 7 & 22. 5 \\
\hline 24. 9 & 25.2 & :ํ. 1 \\
\hline 22. $\theta$ & 23. 0 & 20. 2 \\
\hline 21.7 & 22. 1 & 20.1 \\
\hline 20. 1 & 19. 7 & 17.6 \\
\hline 16.7 & 16. 7 & 15.2 \\
\hline 20.6 & 20.3 & 17. 8 \\
\hline 20. 2 & 20. 2 & 17.4 \\
\hline 19.3 & 18.6 & 15.4 \\
\hline 19. $\mathrm{\theta}$ & 19.6 & 16. 5 \\
\hline $\begin{array}{l}19.4 \\
19.0\end{array}$ & $\begin{array}{l}19.2 \\
18.3\end{array}$ & $\begin{array}{l}16.2 \\
15.5\end{array}$ \\
\hline
\end{tabular}

\begin{tabular}{l} 
WGC7 \\
MPH \\
\hline 24.9 \\
23.9 \\
25.1 \\
21.7 \\
12.1 \\
17.2 \\
18.7 \\
22.5 \\
21.7 \\
24.3 \\
22.7 \\
21.9 \\
19.9 \\
20.1 \\
17.8 \\
16.8 \\
12.4 \\
18.5 \\
18.5 \\
17.3 \\
20.0 \\
20.6 \\
20.6 \\
19.0 \\
18.5 \\
17.0 \\
13.9 \\
16.1 \\
16.1 \\
15.4 \\
16.0 \\
15.6 \\
14.8
\end{tabular}

\begin{tabular}{r} 
WSC \\
MPH \\
\hline 26.9 \\
24.1 \\
26.7 \\
21.8 \\
12.2 \\
17.9 \\
19.0 \\
22.6 \\
22.3 \\
23.5 \\
22.3 \\
26.8 \\
19.7 \\
19.6 \\
17.3 \\
16.8 \\
12.5 \\
17.2 \\
17.5 \\
17.4 \\
22.2 \\
21.2 \\
20.4 \\
19.0 \\
19.0 \\
17.4 \\
14.7 \\
19.1 \\
15.8 \\
15.0 \\
15.6 \\
15.4 \\
14.1
\end{tabular}

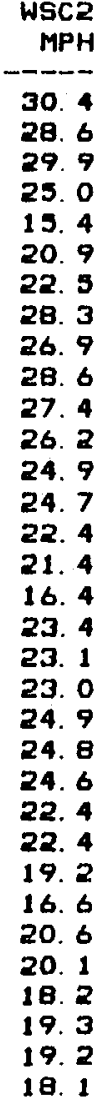


HOURLY DATA LISTING

DOE FREE FLDW DATA - JESS RANCH

\begin{tabular}{|c|c|c|c|c|c|c|c|}
\hline & ID & UNITS & DESCR IP & TIDN & & & \\
\hline & WSC 4 & MPH & TURB INE & $C 14$ & $50-f t$ & & \\
\hline & WSC6 & MPH & TURB INE & C16 & $50-f t$ & & \\
\hline & WSc8 & MPH & TURB INE & $c 18$ & $50-f t$ & & \\
\hline & WSDE & MPH & TURB INE & $D 2$ & $50-f t$ & & \\
\hline & WSD4 & $\mathrm{MPH}$ & TURB INE & D4 & $50-f t$ & - & 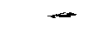 \\
\hline & WSDG & MPH & TURB INE & DG & $50-f t$ & & \\
\hline & WSD3 & MPH & TURB INE & $D 13$ & $50-f t$ & & \\
\hline & WSDS & $\mathrm{MPH}$ & TURB INE & D15 & $50-f t$ & & n \\
\hline & WSD 1 & MPH & TURB INE & $\mathrm{D} 21$ & $50-f t$ & $\cdots$ & \\
\hline & WSEZ & MPH & TURB INE & $E 2$ & $50-f t$ & & \\
\hline & WSE4 & MPH & TURBINE & E4 & $50-f t$ & & \\
\hline & WSEG & MPH & TURBINE & E6 & $50-f t$ & & \\
\hline & WSEB & MPH & TURBINE & $E 8$ & $50-f t$ & & \\
\hline & WSEO & MPH & TURBINE & E10 & $50-f t$ & & \\
\hline & WSE 1 & $\mathrm{MPH}$ & TURB INE & E11 & $50-f t$ & & \\
\hline
\end{tabular}

NOTES:

VALUES ARE THE 60 MINUTE AVERAGE FOR THE PERIOD ENDING ON THE HOUR SHOWR ALL VALUES ARE ROUNDED TO THE NEAREST DECIMAL PLACE. 
DOE FREE FLOW DATA - JESS RANCH

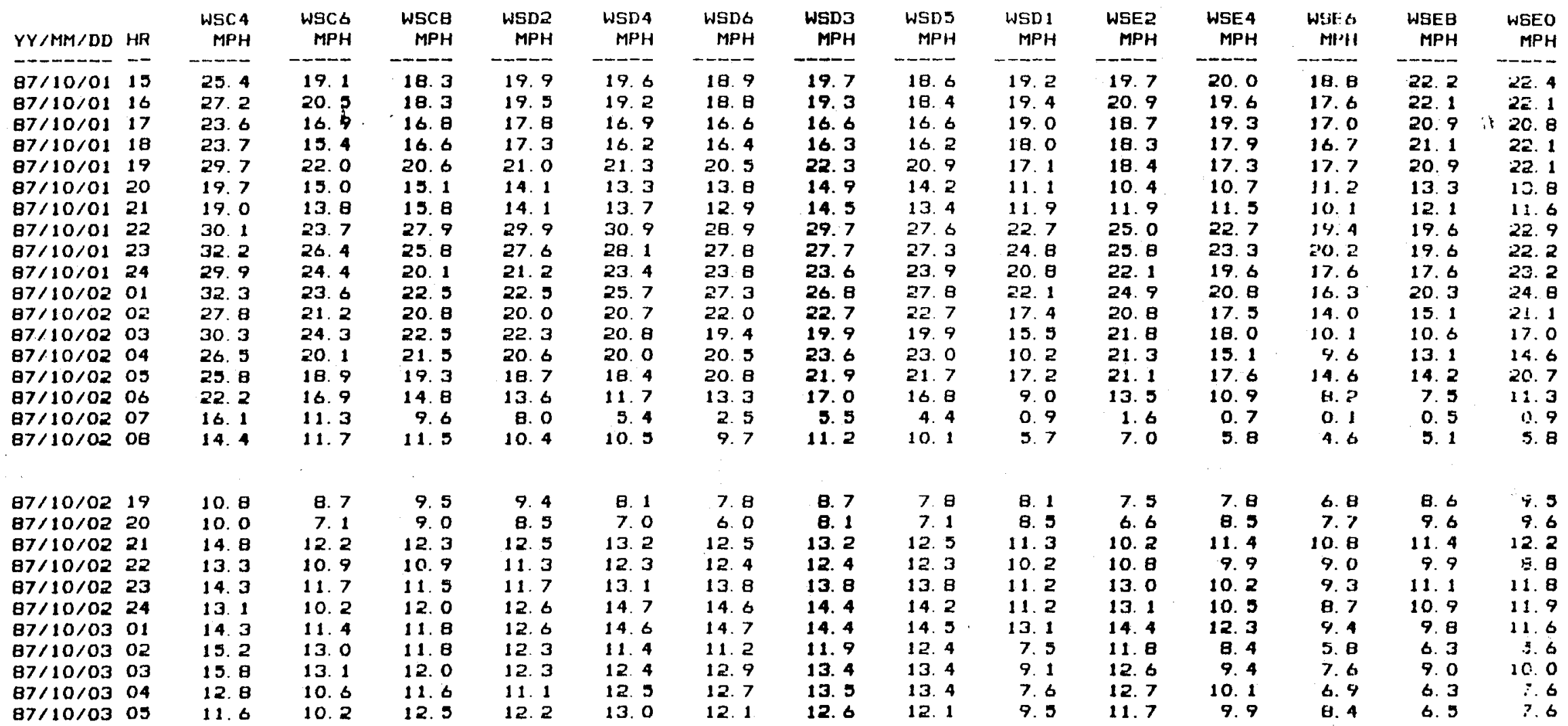

WSE 1

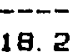

18. 6

17. 3

16. 8

18. 3

12. 5

23. 4

23. 2

20. 4

23. 4

19.6

21.

20. 2

16. 2
4.8

B. 4

6. 1

11. 0

11.3
12.7

12. 9

13. 3

12. 3

13. 1
12. 5

11.2 
DQE FREE FLOW DATA - JESS RANCH

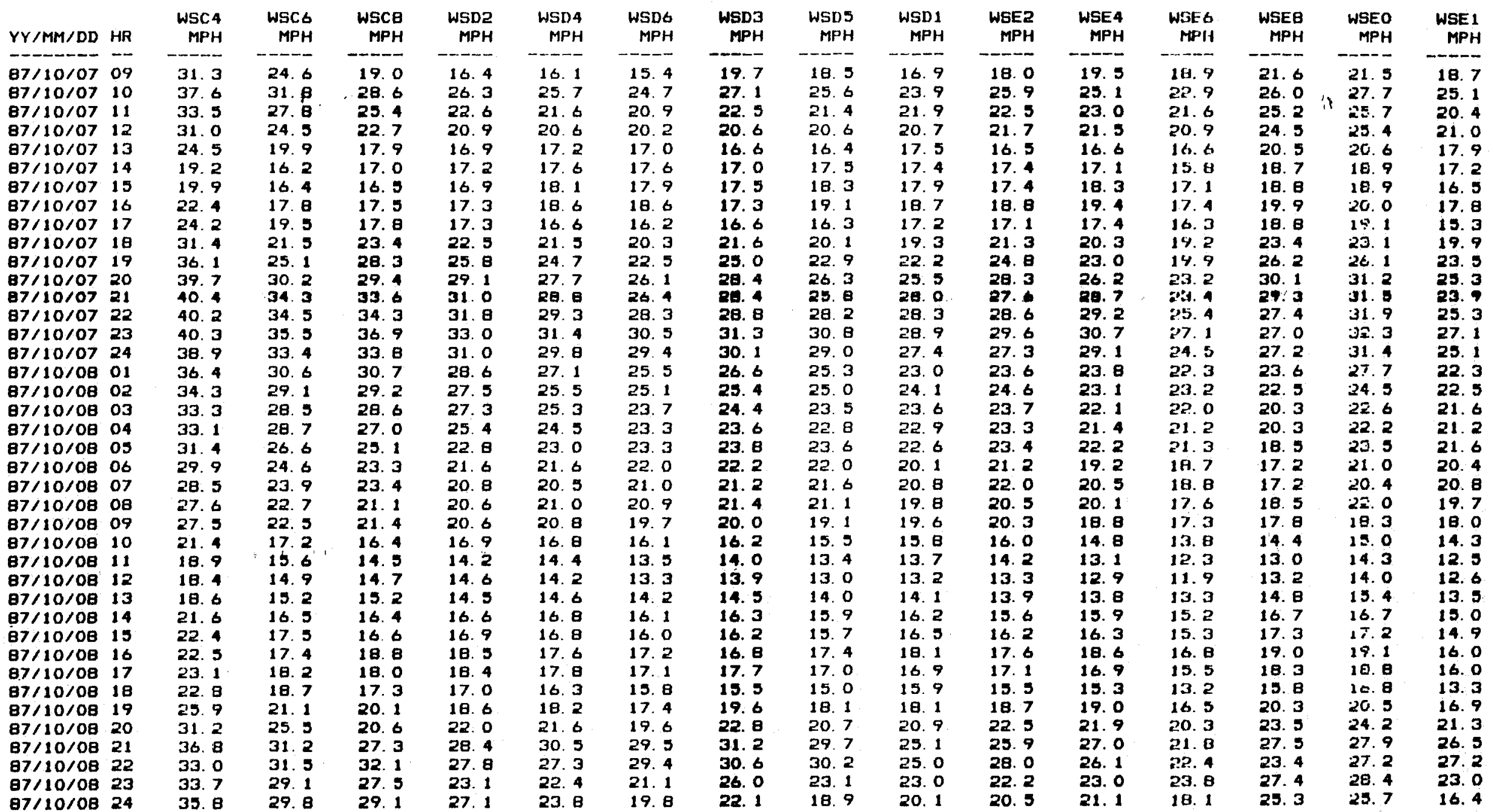


DOE FREE FLOW DATA - JESS RANCH

\begin{tabular}{|c|c|c|c|c|}
\hline & $Y Y / M M / D D$ & HR & $\begin{array}{c}\text { WSC } 4 \\
\text { MPH }\end{array}$ & $\begin{array}{c}\text { WSCE } \\
\text { MPH }\end{array}$ \\
\hline & $-\cdots-$ & - & $\ldots$ & \\
\hline & $87 / 10 / 09$ & 01 & 33.6 & 28. 3 \\
\hline & $87 / 10 / 09$ & 02 & 30.8 & 25. 7 \\
\hline & $87 / 10 / 09$ & 03 & 32.6 & 27.3 \\
\hline & $87 / 10 / 09$ & 04 & 28. 0 & 21.4 \\
\hline & $07 / 10 / 09$ & 05 & 17. 2 & 13. 1 \\
\hline & $87 / 10 / 09$ & DS & 23. 3 & 18. 4 \\
\hline & $87 / 10 / 09$ & 07 & 24.8 & 20.1 \\
\hline & $87 / 10 / 09$ & $\mathrm{OB}$ & 30.9 & 24. 4 \\
\hline & $87 / 10 / 09$ & 09 & 29.4 & 24.3 \\
\hline & $87 / 10 / 09$ & 10 & 31.3 & 26.0 \\
\hline & $87 / 10 / 09$ & 11 & 30.1 & 24.2 \\
\hline & $87 / 10 / 09$ & 12 & 28.8 & 23. 1 \\
\hline & $87 / 10 / 09$ & 13 & 27. 1 & 21.0 \\
\hline & $87 / 10 / 09$ & 14 & 27.0 & 21.4 \\
\hline & $87 / 10 / 09$ & 15 & 24. 0 & 19.0 \\
\hline & $87 / 10 / 09$ & 16 & 23. 3 & 17. 8 \\
\hline & $87 / 10 / 09$ & 17 & 17.1 & 13. 5 \\
\hline & $87 / 10 / 09$ & 18 & 25. 7 & 19.7 \\
\hline & $87 / 10 / 09$ & 19 & 25. 6 & 20.0 \\
\hline & $87 / 10 / 09$ & 20 & 24.6 & 18. \\
\hline & $87 / 10 / 09$ & 21 & 26.7 & 20. 8 \\
\hline & $87 / 10 / 09$ & 22 & 27.6 & 21.7 \\
\hline & $87 / 10 / 09$ & 23 & 27.1 & 21. 9 \\
\hline & $87 / 10 / 09$ & 24 & 24.4 & 20.1 \\
\hline & $87 / 10 / 10$ & 01 & 25. 0 & 20. 7 \\
\hline & $87 / 10 / 10$ & 02 & 21.0 & 18. 3 \\
\hline & $87 / 10 / 10$ & 03 & 18. 6 & 15. 6 \\
\hline & $87 / 10 / 10$ & 04 & 22.3 & 17.9 \\
\hline & $87 / 10 / 10$ & 05 & 22.0 & 17. 7 \\
\hline & $87 / 10 / 10$ & 06 & 19.6 & 16. 8 \\
\hline & $87 / 10 / 10$ & 07 & 20.8 & 17. 1 \\
\hline & $87 / 10 / 10$ & $O B$ & 20.6 & 16. 8 \\
\hline & $87 / 10 / 10$ & 09 & 19. 5 & 15. $\theta$ \\
\hline
\end{tabular}

\begin{tabular}{rrrr} 
WSCB & WSD2 & WSD4 & WSDG \\
MPH & MPH & MPH & MPH \\
\hline 27.4 & -25.7 & -23.9 & -22.7 \\
24.1 & 23.2 & 22.6 & 20.9 \\
26.5 & 25.4 & 23.4 & 21.6 \\
22.8 & 21.7 & 19.8 & 19.1 \\
13.3 & 12.0 & 11.1 & 10.5 \\
18.3 & 17.7 & 16.8 & 15.6 \\
18.6 & 18.0 & 17.1 & 16.7 \\
23.2 & 21.8 & 20.4 & 19.1 \\
22.5 & 21.1 & 20.4 & 18.8 \\
24.1 & 22.7 & 20.8 & 19.7 \\
22.9 & 22.0 & 20.5 & 20.4 \\
21.9 & 21.1 & 20.8 & 20.0 \\
20.1 & 19.6 & 18.7 & 18.9 \\
19.8 & 20.0 & 18.9 & 17.8 \\
17.7 & 17.9 & 18.1 & 17.4 \\
17.3 & 17.2 & 17.3 & 17.0 \\
12.8 & 12.4 & 12.9 & 13.2 \\
17.5 & 15.7 & 14.2 & 13.8 \\
18.0 & 17.2 & 16.2 & 15.2 \\
18.2 & 18.0 & 17.6 & 18.1 \\
23.1 & 22.1 & 20.9 & 20.4 \\
21.7 & 21.8 & 21.3 & 20.0 \\
20.1 & 19.4 & 19.2 & 17.9 \\
18.6 & 18.5 & 17.7 & 16.7 \\
19.0 & 18.5 & 17.4 & 16.3 \\
17.4 & 16.9 & 16.3 & 15.3 \\
14.4 & 13.5 & 12.2 & 11.2 \\
16.4 & 15.6 & 14.7 & 14.4 \\
15.8 & 15.0 & 14.8 & 13.5 \\
15.2 & 15.1 & 15.0 & 14.3 \\
16.0 & 16.0 & 15.7 & 14.9 \\
15.8 & 16.1 & 16.6 & 15.4 \\
14.2 & 13.9 & 14.2 & 13.5
\end{tabular}

\begin{tabular}{rrrr} 
WSD & WSDS & WSD1 & WSE2 \\
MPH & MPH & MPH & MPH \\
\hline 23.7 & 22.2 & 20.7 & 21.4 \\
21.9 & 20.0 & 20.8 & 20.7 \\
22.2 & 21.2 & 21.4 & 21.8 \\
19.2 & 18.7 & 17.8 & 17.2 \\
11.3 & 10.5 & 12.0 & 12.2 \\
16.3 & 15.3 & 16.8 & 16.8 \\
17.2 & 16.6 & 17.3 & 17.6 \\
20.3 & 19.1 & 20.6 & 20.6 \\
20.0 & 18.0 & 19.5 & 18.6 \\
20.1 & 19.1 & 21.5 & 21.2 \\
20.1 & 19.8 & 21.3 & 21.2 \\
20.0 & 19.5 & 21.2 & 20.7 \\
17.9 & 18.7 & 18.9 & 18.5 \\
18.8 & 17.5 & 19.2 & 19.3 \\
17.7 & 17.2 & 18.2 & 17.8 \\
16.9 & 16.9 & 17.1 & 17.0 \\
12.8 & 13.5 & 14.1 & 13.7 \\
14.4 & 13.6 & 14.4 & 14.0 \\
16.4 & 15.6 & 16.3 & 16.9 \\
17.5 & 17.9 & 17.6 & 18.9 \\
20.9 & 20.0 & 20.7 & 21.0 \\
20.9 & 19.4 & 20.4 & 20.9 \\
16.5 & 17.0 & 18.7 & 17.4 \\
17.0 & 15.8 & 16.7 & 16.2 \\
16.7 & 15.7 & 17.9 & 17.4 \\
15.2 & 14.4 & 15.3 & 15.1 \\
11.3 & 9.9 & 11.2 & 10.9 \\
14.3 & 13.9 & 14.5 & 14.2 \\
14.3 & 12.9 & 14.1 & 13.9 \\
14.9 & 14.0 & 13.9 & 13.5 \\
15.4 & 14.3 & 14.1 & 13.8 \\
16.2 & 15.1 & 13.9 & 13.8 \\
13.9 & 12.8 & 13.1 & 12.6
\end{tabular}

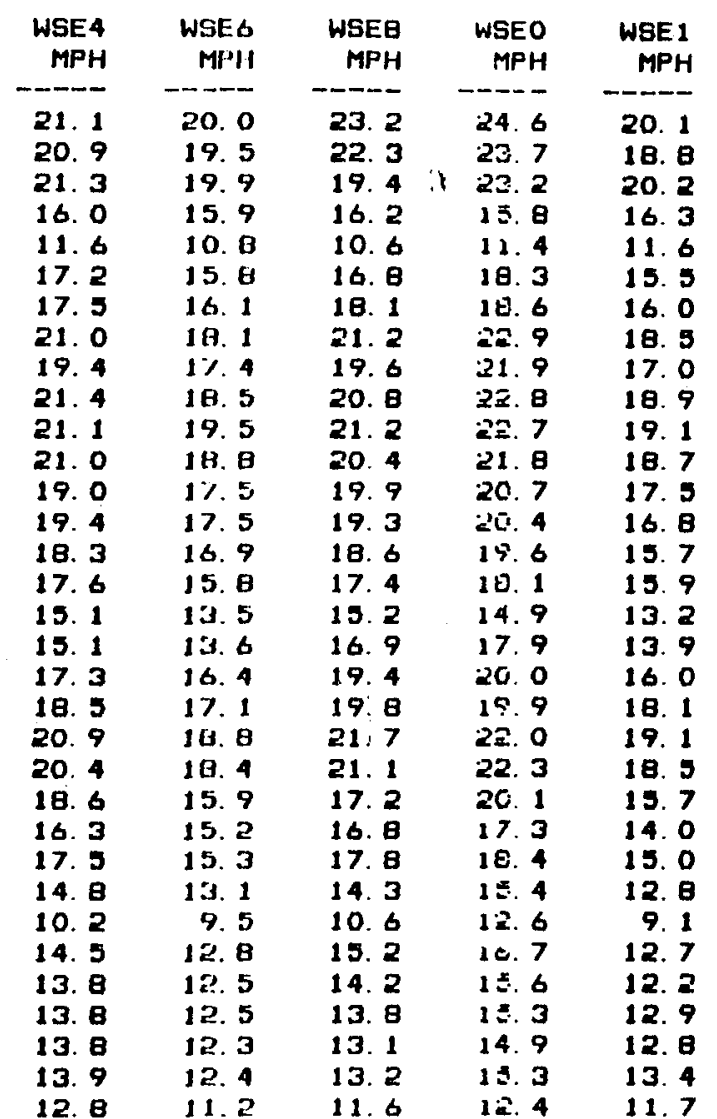


HOURLY DATA LISTING

\begin{tabular}{|c|c|c|c|c|}
\hline \multirow{2}{*}{$\begin{array}{c}\text { ID } \\
- \text { WSE3 }\end{array}$} & \multirow{2}{*}{$\begin{array}{l}\text { UNITS } \\
\text { MPH }\end{array}$} & \multicolumn{2}{|c|}{ DESCR IPTION } & \multirow[b]{2}{*}{$50-f t$} \\
\hline & & TURB INE & E13 & \\
\hline WSES & $\mathrm{MPH}$ & TURB INE & E15 & $50-f t$ \\
\hline WSEA & $\mathrm{MPH}$ & TURB I NE & E18 & $50-f t$ \\
\hline WSEB & MPH & TURB INE & E2O & $50-f t$ \\
\hline WSEC & $\mathrm{MPH}$ & TURB INE & E22 & $50-f t$ \\
\hline WSF 1 & $M P H$ & TURB INE & $F 1$ & $35-f t$ \\
\hline WSF3 & MPH & TURB INE & $F_{3}$ & $35-f t$ \\
\hline WSF 5 & $\mathrm{MPH}$ & TURB INE & $\mathrm{HE}$ & $50-f t$ \\
\hline WSF7 & MPH & TURB INE & F7 & $35-f t$ \\
\hline WSF9 & $\mathrm{MPH}$ & TURB INE & $F 9$ & $35-f t$ \\
\hline WSFE & $\mathrm{MPH}$ & TURB INE & $F 12$ & $35-f t$ \\
\hline WSG 1 & $M P H$ & TURB INE & GI & $35-f t$ \\
\hline WSG3 & $\mathrm{MPH}$ & TURB INE & 63 & $35-f t$ \\
\hline WSG5 & MPH & TURB INE & 65 & $35-f t$ \\
\hline WSG7 & MPH & TURB INE & 67 & $35-f t$ \\
\hline
\end{tabular}

NOTES:

VALUES ARE THE GO MINUTE AVERAGE FOR THE PERIOD ENDING ON THE HOUR SHOWN. ALL VALUES ARE RQUNDED TO THE NEAREST DECIMAL PLACE. 
DOE FREE FLOW DATA - JESS RANCH

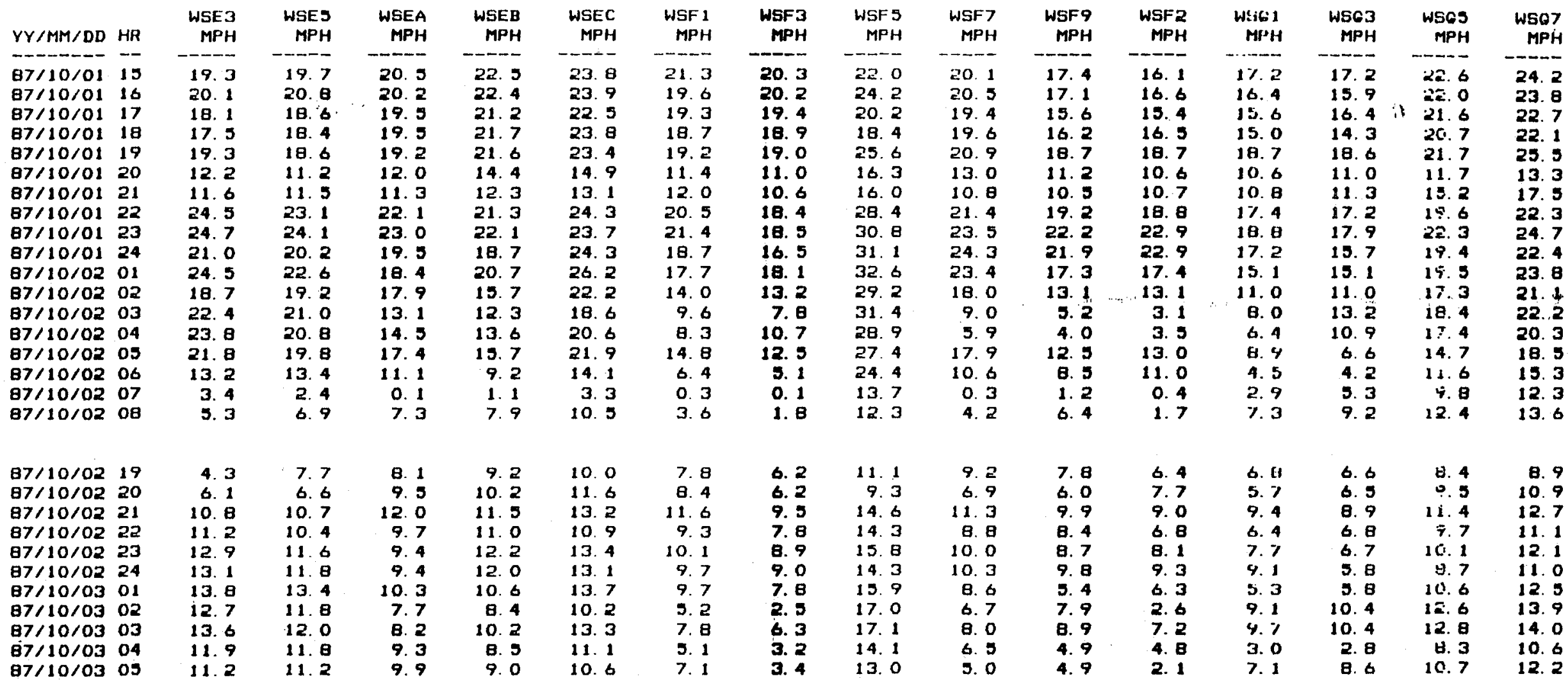


DOE FREE FLOW DATA - JESS RANCH

\begin{tabular}{|c|c|c|c|c|c|c|c|c|c|c|c|c|c|c|c|c|}
\hline$Y Y / M M / D D$ & $H R$ & $\begin{array}{r}\text { WSE3 } \\
\mathrm{MPH}\end{array}$ & $\begin{array}{r}\text { WSES } \\
\text { MPH }\end{array}$ & $\begin{array}{c}\text { WSEA } \\
\text { MPH }\end{array}$ & $\begin{array}{c}\text { WSEB } \\
\text { MPH }\end{array}$ & $\begin{array}{c}\text { WGEC } \\
\text { MPH }\end{array}$ & $\begin{array}{c}\text { WSF } 1 \\
\text { MPH }\end{array}$ & $\begin{array}{l}\text { WSF3 } \\
\text { MPH }\end{array}$ & $\begin{array}{c}\text { WSF5 } \\
\text { MPH }\end{array}$ & $\begin{array}{r}\text { WSF7 } \\
\text { MPH }\end{array}$ & $\begin{array}{c}\text { WSF9 } \\
\text { MPH }\end{array}$ & $\begin{array}{r}\text { WSF2 } \\
\text { MPH }\end{array}$ & $\begin{array}{l}\text { WSG: } 1 \\
\text { MHII }\end{array}$ & $\begin{array}{c}\text { WSG3 } \\
\mathrm{MPH}\end{array}$ & $\begin{array}{c}\text { WSGS } \\
\text { MPH }\end{array}$ & $\begin{array}{r}\text { WSE7 } \\
\text { MPH }\end{array}$ \\
\hline $07 / 10 / 07$ & 09 & 19.6 & 20. 5 & 22. 4 & 25.0 & 25.7 & 17.9 & 16. 7 & 23.9 & 18. 6 & 15. 8 & 16. 5 & 15.2 & 14. 2 & 22. 2 & 26.6 \\
\hline $07 / 10 / 07$ & 10 & 25.7 & 25,2 & 25. 4 & 27.4 & 30. 2 & 23. 4 & 23.6 & 35.4 & 22.7 & 20.3 & 19. 2 & 20.1 & 20.9 & 27.6 & 30.9 \\
\hline $87 / 10 / 07$ & 11 & 21.9 & 22.6 & 24. 2 & 26.5 & 27.7 & 23. 1 & 22. 4 & 30.3 & 22.7 & 19.8 & 18.9 & 19.4 & 18. 4 & 26.3 & 29.6 \\
\hline $87 / 10 / 07$ & 12 & 21.9 & 21.8 & 22. 8 & 24.9 & 26.9 & 23. 0 & 22. 3 & 28. 1 & 21.4 & 18.6 & 20.7 & 18.7 & 18. 4 & 24.0 & 26.8 \\
\hline $87 / 10 / 07$ & 13 & 14. 1 & 16. 4 & 14.4 & 19. 9 & 22. 8 & 19.6 & 18. 1 & 22. 9 & 17.0 & 16.7 & 18. 5 & 15.8 & 16. 4 & 21.9 & 25.6 \\
\hline $87 / 10 / 07$ & 14 & 15. 1 & 17.2 & is. 3 & 18. 8 & 20.5 & 18. 1 & 16. 7 & 19. 8 & 18. 2 & 17.7 & 19.4 & 16. 7 & 16. 1 & 22.1 & 25.2 \\
\hline $87 / 10 / 07$ & 15 & 16. 8 & 17. 1 & 18. 4 & 19. 7 & 20.0 & 1日. 7 & 17. 4 & 19. 1 & 17. 5 & 16. 4 & 17.7 & 15. 6 & 15. 2 & 26.9 & 23. 7 \\
\hline $87 / 10 / 07$ & 16 & 18. 2 & 18. 7 & 19. 5 & 20.8 & 21.4 & 19.6 & 18. 3 & 20.9 & 18. 5 & 16. 4 & 17. 3 & 15. 5 & 15.0 & 20.3 & 24.0 \\
\hline $87 / 10 / 07$ & 17 & 16.4 & 17. 1 & 18. 2 & 19.6 & 20.4 & 17. 7 & 17. 2 & 22. 2 & 16.5 & 14. 6 & 16. 3 & 11.6 & 14.6 & 10.9 & 21.0 \\
\hline $87 / 10 / 07$ & 18 & 21.2 & 21.4 & 21.5 & 24.6 & 25. 1 & 22.0 & 20.9 & 25.4 & 20.3 & 18. 0 & 20.1 & 16.6 & 17. 5 & 24.1 & 25.7 \\
\hline $87 / 10 / 07$ & 19 & 25.0 & 24.6 & 24.0 & 27.1 & 28.6 & 23. 9 & 23. 8 & 29.1 & 24.3 & 21.3 & 20.6 & 21.3 & 19.7 & 20.3 & 29.4 \\
\hline $87 / 10 / 07$ & 20 & 27.9 & 27.7 & 27.1 & 30.7 & 32. 9 & 25.7 & 28. 1 & 35.8 & 27.7 & 23. 1 & 23. 2 & 2a. 2 & 22.9 & 32.0 & 31.8 \\
\hline $87 / 10 / 07$ & 21 & 264 & 27. 9 & 26. 4 & 29.7 & 33.6 & 24.3 & 26.6 & 38.6 & 28.5 & 23. 8 & 25.4 & 22.4 & 21.4 & 31.3 & 32.4 \\
\hline $87 / 10 / 07$ & 22 & 27.5 & 28. 7 & 28.2 & 29.3 & 34. 0 & 27. 0 & 25. $B$ & 39.5 & 28. 9 & 24. 5 & 25.9 & 22.6 & 22. 0 & 29.0 & 31.1 \\
\hline $87 / 10 / 07$ & 23 & 30. 1 & 28. 7 & 29.6 & 29.5 & 34.7 & 28.4 & 24.9 & 39.7 & 29.7 & 24. 8 & 26. 6 & 23.6 & 22.4 & 25.9 & 31.0 \\
\hline $87 / 10 / 07$ & 24 & 28.0 & 26.7 & 26.7 & 29.3 & 33. 5 & 25.7 & 24. 9 & 38.6 & 27.3 & 22. 3 & 24. $\theta$ & 23. 5 & 21.5 & 25.5 & 31.7 \\
\hline$B 7 / 10 / 08$ & 01 & 23. 6 & 22.5 & 24.3 & 25.7 & 29.7 & 23. 4 & 21.4 & 36.5 & 25. 5 & 21.3 & 22. 4 & 19. 2 & 19.6 & 26.1 & 28.1 \\
\hline $87 / 10 / 08$ & 02 & 240 & 23. 5 & 25.1 & 24.7 & 27.0 & $24: 0$ & 21. 0 & 34.1 & 26.1 & 23. 5 & 24.4 & 20.0 & 16. $\theta$ & 16. 3 & 24.4 \\
\hline $87 / 10 / 08$ & 03 & 23. 0 & 22. 8 & 24. 1 & 22.8 & 25. 5 & 22.4 & 19. 1 & 33. 1 & 24. 4 & 22.9 & 24.3 & 18.9 & 14. 9 & 18.2 & 23.6 \\
\hline $87 / 10 / 08$ & 04 & 22. 5 & 22. 1 & 22. 9 & 22.7 & 24.4 & 21.9 & 19. 1 & 32. 4 & 23. 3 & 22. 1 & 23. 4 & 19.9 & 16. 7 & 174 & 18. 8 \\
\hline $87 / 10 / 08$ & 05 & 22. 9 & 22. 1 & 23. 2 & 21.7 & 25.4 & 22. 4 & 17.6 & 30.5 & 24. 1 & 21.4 & 22. 6 & 16. 3 & 15. 3 & 19. 1 & 22. 9 \\
\hline $87 / 10 / 08$ & 06 & 20.7 & 19. 7 & 20.5 & 19. 5 & 23. 0 & 19.7 & 16. 0 & 28.7 & 21.2 & 17.7 & 19.0 & 13. 7 & 12. 6 & 19.3 & 21.7 \\
\hline $87 / 10 / 08$ & 07 & 21.5 & 20.5 & 20.7 & 19.8 & 21.8 & 20.1 & 16. 2 & 27.8 & 22. 0 & 20.8 & 21.9 & 18. 1 & 15. 4 & 14.9 & 18.0 \\
\hline $87 / 10 / 0 \theta$ & 08 & 20.6 & 18. 9 & 19. 1 & 19.6 & 22.9 & 18. 5 & 17. 6 & 26.4 & 22. 5 & 20. $B$ & 21.5 & 17.6 & 15. 6 & 15.9 & 17. $\mathrm{s}$ \\
\hline $87 / 10 / 08$ & 09 & 19.4 & 18. 7 & 18.4 & 19.2 & 20.1 & 19.1 & 16. 2 & 27.0 & 20.5 & 19.9 & 20. 8 & 19. 5 & 15. 9 & 15. 2 & 15. 2 \\
\hline $87 / 10 / 08$ & 10 & 15.3 & 15. 0 & 15. 4 & 15. 6 & 16.3 & 15. 4 & 13. 8 & 20.4 & 17.3 & 16. 4 & 17.0 & 15: 2 & 13. 4 & 12.4 & 12. 7 \\
\hline $87 / 10 / 0 \theta$ & 11 & 13. 6 & 13. 2 & 13. 2 & 13. 3 & 15. 1 & 13. 5 & 12. 2 & 17.7 & 14. 6 & 12. 9 & 13. 1 & 11.4 & 10. 0 & $1=1$ & 13. 4 \\
\hline $87 / 10 / 08$ & 12 & 13.1 & 12. 6 & 12. 7 & 13. 8 & 14. 8 & 13. 2 & 12. 4 & 16. 9 & 13. 5 & 12. 3 & 12. 0 & 10.8 & 10.2 & $1=5$ & 14. 0 \\
\hline $87 / 10 / 08$ & 13 & 13. 7 & 13. 4 & 14. 0 & 15.6 & 16. 5 & 14. 5 & 13. 8 & 17.0 & 14. 4 & 12. 5 & 12. 1 & 11.2 & 11.3 & 150 & 17. 3 \\
\hline$B 7 / 10 / 08$ & 14 & 15. 1 & 14. 9 & 16. 2 & 17. 3 & 18. 0 & 16. 7 & 15. 6 & 18. 7 & 15. 9 & 13. 8 & 13. 3 & 12.8 & 12. 5 & $1 \dot{0.8}$ & 18: 6 \\
\hline $87 / 10 / 08$ & 15 & 15. 8 & 15. 6 & 16. 3 & 17.8 & 1日. 3 & 16. 9 & 15. 8 & 20.3 & 15. 4 & 13. 7 & 12. 4 & 13.7 & 13. 6 & 17.5 & 19. 9 \\
\hline $87 / 10 / 08$ & 16 & 17.2 & 17. 2 & 1日. 7 & 19. 8 & 20.1 & 19.2 & 17. 2 & 20.9 & 17. 8 & 15. 7 & 14.6 & is. 3 & 14. 4 & 19.3 & 22. 5 \\
\hline $87 / 10 / 08$ & 17 & 16.5 & 16.3 & 16. 7 & 18. 4 & 19.0 & 17.5 & 17.0 & 21.3 & 17.1 & 14.6 & 14. 3 & 14.6 & 15. 1 & 151 & 20.5 \\
\hline $87 / 10 / 08$ & 18 & 14. 3 & 14.9 & 14.6 & 15.9 & 17.6 & 14. 8 & 14. 5 & 22. 4 & 16. 1 & 13. 8 & 13.0 & 14.4 & 13. 9 & 18. 7 & 19.9 \\
\hline $87 / 10 / 08$ & 19 & 17.6 & 19.4 & 19. 1 & 20.9 & 22.5 & 17. 2 & 17.9 & 25. 9 & 17.6 & 15. 2 & 17.7 & 15.7 & 15. 3 & $2 \approx 0$ & 25. 4 \\
\hline $87 / 10 / 00$ & 20 & 23.0 & 22. 4 & 23. 4 & 25.3 & 25. 8 & 22.7 & 20. 9 & 30.2 & 21.7 & 21. 1 & 23. 4 & $E^{2} 0.7$ & 20.0 & 27.6 & 30.8 \\
\hline $87 / 10 / 08$ & 21 & 27.2 & 24.9 & 23. 7 & 27.4 & 30. 2 & 22. 3 & 26. 1 & 35.6 & 24. 2 & 20. 2 & 20.0 & 20.7 & 19.3 & 25.4 & 29.0 \\
\hline $87 / 10 / 08$ & 22 & 28.7 & 27.0 & 25. 8 & 24. 2 & 28.9 & 22.9 & 22. 1 & 32.6 & 24.4 & 20. $\mathrm{B}$ & 19.7 & 19. 7 & 18. $\theta$ & 23.4 & 29.0 \\
\hline $87 / 10 / 0 B$ & 23 & 23. 3 & 22. 8 & 24.9 & 28. 2 & 29.8 & 26. 3 & 25. 0 & 33. 0 & 26. 3 & 23. 0 & 22. 0 & 23. 9 & 21.9 & 28. 9 & 31. \\
\hline $87 / 10 / 08$ & 24 & 19.5 & 20.6 & 22. 1 & 25.7 & 28.4 & 19. 9 & 22. 3 & 35.1 & 23.6 & 19.9 & 20. 3 & 19.2 & 18. 8 & 25.9 & 29.6 \\
\hline
\end{tabular}


DOE FREE FLOW DATA - JESS RANCH

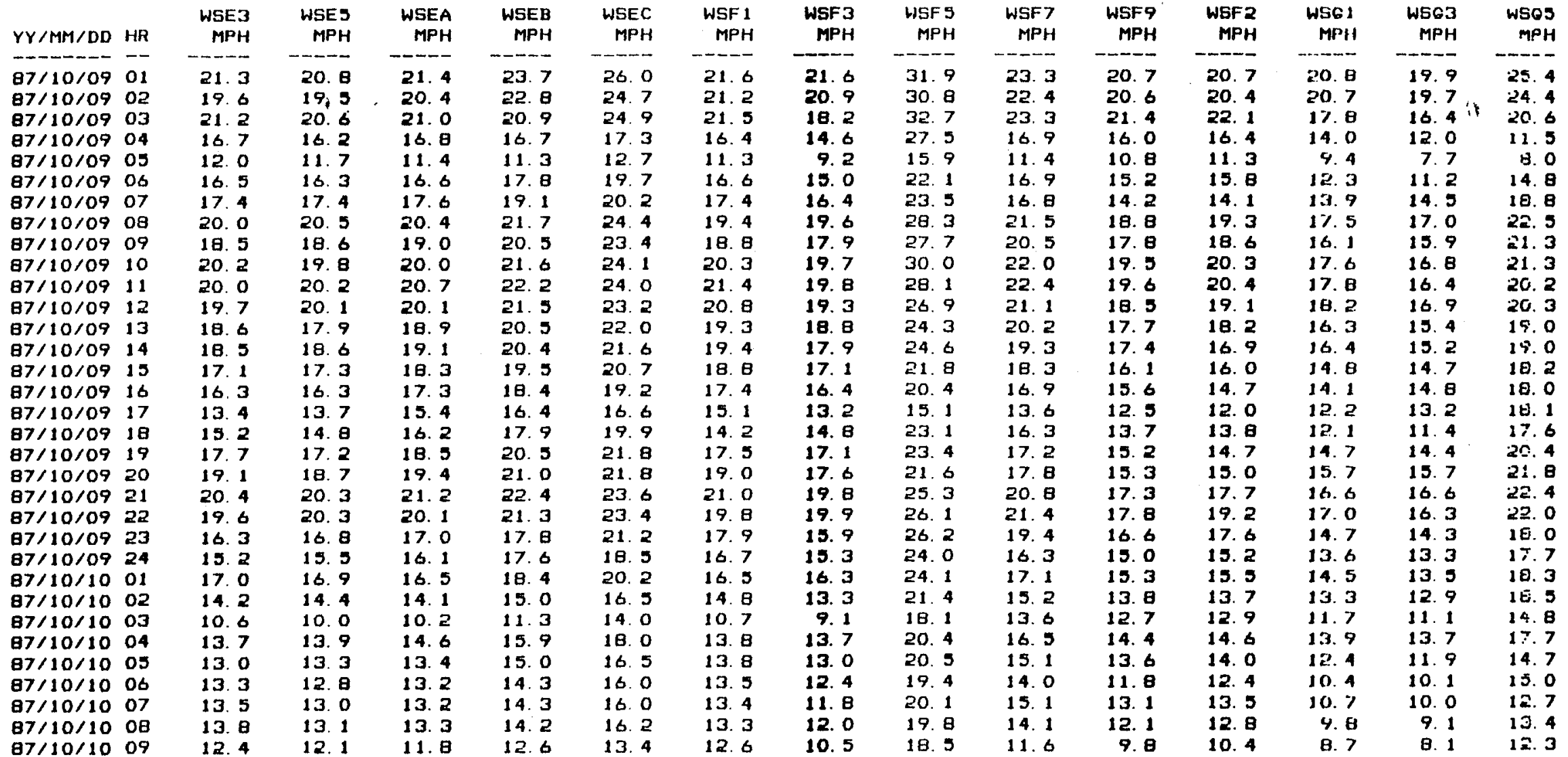

W6Q7 $\mathrm{MPH}$

27. 4

.

-1
14.6

9.9

16.9
22.0

25. 0

23.8
24.7

23. 0

22. 5

21. 0

20. 3

19. 8

21. 1

20. 8

23. 6

26. 0

24.3

24. 3

21.3
19.8

20. 7

20. 9

17. 9

20. 4

17.1
16.4

16. 4
14.8

14. 9
13. 9 
HOURLY DATA LISTING

$\therefore$

DOE FREE FLOW DATA - JESS RANCH

\begin{tabular}{|c|c|c|c|c|}
\hline \multirow{2}{*}{$\frac{\text { ID }}{\text { WSGB }}$} & \multirow{2}{*}{$\begin{array}{l}\text { UNITS } \\
\text { MPH }\end{array}$} & \multicolumn{2}{|c|}{ DESCR IPTIDN } & \multirow[b]{2}{*}{$35-f t$} \\
\hline & & TURBINE & 68 & \\
\hline WSGO & MPH & TURBINE & Q10 & $35-f t$ \\
\hline WSGE & $\mathrm{MPH}$ & TURB INE & G12 & $35-f t$ \\
\hline WSH1 & MPH & TURB INE & $\mathrm{HI}$ & $50-f t$ \\
\hline WSH7 & $\mathrm{MPH}$ & TURB INE & $\mathrm{H7}$ & $50-f t$ \\
\hline WSHO & MPH & TURB INE & H1O & $50-f t$ \\
\hline WSHE & MPH & TURB INE & $\mathrm{H} 12$ & $50-f t$ \\
\hline WSHS & MPH & TURBINE & $H 15$ & $50-f t$ \\
\hline WSI 1 & MPH & TURB INE & I 1 & $50-f t$ \\
\hline WSI3 & $\mathrm{MPH}$ & TURB INE & 13 & $50-f t$ \\
\hline WSIS & $\mathrm{MPH}$ & TURB INE & I 5 & $50-f t$ \\
\hline WSIg & MPH & TURBINE & 19 & $50-f t$ \\
\hline WSI 4 & MPH & TURB INE & 114 & $50-f t$ \\
\hline WSU' & MPH & TURB INE & 16 & $50-f t$ \\
\hline WSJE & MPH & TURB INE & 38 & $50-f t$ \\
\hline
\end{tabular}

NOTES:

VALUES ARE THE GO MINUTE AVERAgE FDR THE PERIDD ENDING ON THE HOUR SHOWN. ALL VALUES ARE ROUNDED TO THE NEAREST DECIMAL PLACE. 
DUE FREE FLOW DATA - JESS RANCH

\begin{tabular}{ll}
$Y Y / M M / D D$ & $H R$ \\
\hline $67 / 10 / 01$ & 15 \\
$87 / 10 / 01$ & 16 \\
$87 / 10 / 01$ & 17 \\
$87 / 10 / 01$ & 18 \\
$87 / 10 / 01$ & 19 \\
$87 / 10 / 01$ & 20 \\
$87 / 10 / 01$ & 21 \\
$87 / 10 / 01$ & 22 \\
$87 / 10 / 01$ & 23 \\
$87 / 10 / 01$ & 24 \\
$87 / 10 / 02$ & 01 \\
$87 / 10 / 02$ & 02 \\
$87 / 10 / 02$ & 03 \\
$87 / 10 / 02$ & 04 \\
$87 / 10 / 02$ & 05 \\
$87 / 10 / 02$ & 06 \\
$87 / 10 / 02$ & 07 \\
$87 / 10 / 02$ & 06 \\
\end{tabular}

\begin{tabular}{rr} 
WSGG & WSGO \\
$M P H$ & $M P H$ \\
\hline 17.4 & 19.9 \\
17.2 & 19.0 \\
16.1 & 18.3 \\
16.3 & 17.3 \\
19.4 & 20.6 \\
10.5 & 10.9 \\
9.5 & 10.8 \\
17.2 & 19.1 \\
18.9 & 19.3 \\
16.8 & 17.6 \\
14.6 & 17.5 \\
11.1 & 13.1 \\
1.4 & 5.4 \\
2.1 & 4.3 \\
9.8 & 11.0 \\
5.8 & 4.1 \\
0.5 & 0.9 \\
2.8 & 6.5 \\
\end{tabular}

\begin{tabular}{rr} 
WSG2 & WSH1 \\
MPH & MPH \\
\hdashline 21.4 & -2.9 \\
20.2 & 25.9 \\
20.5 & 21.9 \\
19.5 & 19.9 \\
22.5 & 27.6 \\
11.7 & 17.5 \\
13.6 & 17.2 \\
21.0 & 29.9 \\
21.7 & 32.2 \\
18.9 & 32.1 \\
18.9 & 33.5 \\
15.6 & 30.1 \\
15.7 & 32.7 \\
13.4 & 31.7 \\
12.1 & 29.1 \\
6.9 & 25.6 \\
5.1 & 14.6 \\
9.5 & 12.9
\end{tabular}

\begin{tabular}{r} 
WSH7 \\
$M P H$ \\
\hdashline 21.9 \\
21.7 \\
19.1 \\
18.4 \\
22.6 \\
14.4 \\
14.9 \\
32.3 \\
30.4 \\
24.0 \\
24.8 \\
22.6 \\
25.1 \\
22.6 \\
20.8 \\
16.0 \\
8.7 \\
10.9
\end{tabular}

\begin{tabular}{r} 
WSHO \\
MPH \\
\hline 22.0 \\
22.1 \\
20.1 \\
19.8 \\
23.3 \\
13.3 \\
14.8 \\
32.8 \\
31.9 \\
26.1 \\
27.8 \\
21.8 \\
22.7 \\
19.8 \\
19.8 \\
12.1 \\
5.1 \\
10.3
\end{tabular}

\begin{tabular}{r} 
WSH2 \\
$M P H$ \\
\hdashline 19.1 \\
20.9 \\
18.5 \\
17.6 \\
20.7 \\
14.9 \\
14.1 \\
29.9 \\
28.9 \\
24.0 \\
26.6 \\
24.9 \\
26.9 \\
25.1 \\
24.9 \\
20.5 \\
9.2 \\
9.2
\end{tabular}

WSH5
MPH
-22.0
22.0
21.4
19.8
19.3
21.2
12.6
15.1
30.0
29.9
24.3
24.8
20.7
24.0
20.2
19.1
12.8
5.9
8.7

\begin{tabular}{r} 
WSI \\
$M P H$ \\
\hline 22.6 \\
21.9 \\
20.9 \\
19.8 \\
22.9 \\
13.6 \\
15.0 \\
31.1 \\
31.4 \\
26.0 \\
28.0 \\
21.6 \\
21.1 \\
17.8 \\
19.1 \\
11.0 \\
3.3 \\
9.2
\end{tabular}

WSI3
$M P H$
-22.9
22.9
24.2
21.9
21.2
23.1
15.0
15.3
29.5
31.9
26.9
29.4
22.1
18.9
15.1
20.6
11.2
2.4
9.1

\begin{tabular}{r} 
WSIJ \\
MPH \\
\hdashline 22.5 \\
22.8 \\
19.8 \\
18.7 \\
20.9 \\
13.3 \\
14.8 \\
27.5 \\
30.4 \\
26.4 \\
28.6 \\
21.3 \\
16.3 \\
14.2 \\
21.1 \\
10.0 \\
2.2 \\
7.4
\end{tabular}

$87 / 10 / 0219$

$\begin{array}{rr}7.8 & 8.2 \\ 6.6 & 7.3 \\ 9.4 & 10.6 \\ 8.0 & 7.3 \\ 7.8 & 8.2 \\ 9.4 & 9.5 \\ 5.3 & 5.2 \\ 4.7 & 7.3 \\ 6.1 & 8.9 \\ 3.8 & 1.9 \\ 2.0 & 5.1\end{array}$

9.3
9. 9
11.8
9.3
9.7
9.3
7.8
10.1
11.3
4.0
8.

$\begin{array}{rr}11.8 & 10.5 \\ 9.6 & 9.3 \\ 15.6 & 14.1 \\ 15.4 & 12.3 \\ 17.1 & 13.1 \\ 15.7 & 13.4 \\ 17.3 & 13.7 \\ 18.1 & 13.9 \\ 18.3 & 13.6 \\ 16.1 & 9.4 \\ 14.5 & 12.3\end{array}$

9.7
7.1
14.2
13.0
13.9
15.6
15.2
11.0
12.7
10.3
13.0

$\begin{array}{rr}10.3 & 9.7 \\ 9.2 & 8.7 \\ 13.9 & 13.0 \\ 12.8 & 11.9 \\ 14.0 & 12.6 \\ 12.9 & 12.9 \\ 13.6 & 13.1 \\ 14.7 & 10.8 \\ 14.3 & 11.4 \\ 10.1 & 6.6 \\ 9.8 & 8.1\end{array}$

8. 9
6.5
13.2
12.2
13.7
15.2
15.1
10.
11.
9.

10.2
8. 7
12.8
13.1
15.1
16.0
16.2
9.4
11.2
8.7

10.
9.
11.
12.
14.
14.
15.
8.
10.
8.

10. 1
9.9
11.6
12.4
14.6
14.9
15.3
8. 1
10.9
8. 0
10.6

9. 4
8. 3
11.3

11. 3

12. 1

13. 5

14. 7

14. 2
5.7

7. 8

5. 5

\begin{tabular}{rr}
$M P H$ & $M P H$ \\
\hdashline 24.1 & 23.8 \\
23.7 & 24.2 \\
23.7 & 22.9 \\
22.2 & 22.8 \\
22.1 & 25.5 \\
11.4 & 13.5 \\
15.4 & 13.8 \\
27.5 & 22.8 \\
30.0 & 20.0 \\
26.2 & 22.2 \\
27.5 & 22.8 \\
20.9 & 19.7 \\
13.9 & 10.6 \\
8.7 & 12.1 \\
20.1 & 18.1 \\
5.9 & 4.0 \\
0.8 & 6.5 \\
5.1 & 73
\end{tabular}

10. 7

14. 7

11. 8

13. 3

13. 3

7. 8

10. 6

10. 5
6.5
9.4

10. 9

11. 1

14. 3

11. 8

13. 3

13.8
0.9

อ. 4

10. 3

E. 1
MPH
22.4
22.8
21.7
21.6
24.9
11.1
13.5
23.7
22.9
26.1
26.2
21.6
11.1
9.4
20.1
7.3
1.5
2.3

9. 3

6. 6

6.3
5. 7

B. 8
10. 4

9.6

10.9

4.8
7.7 
DDE FREE FLOW DATA - JESS RANCH

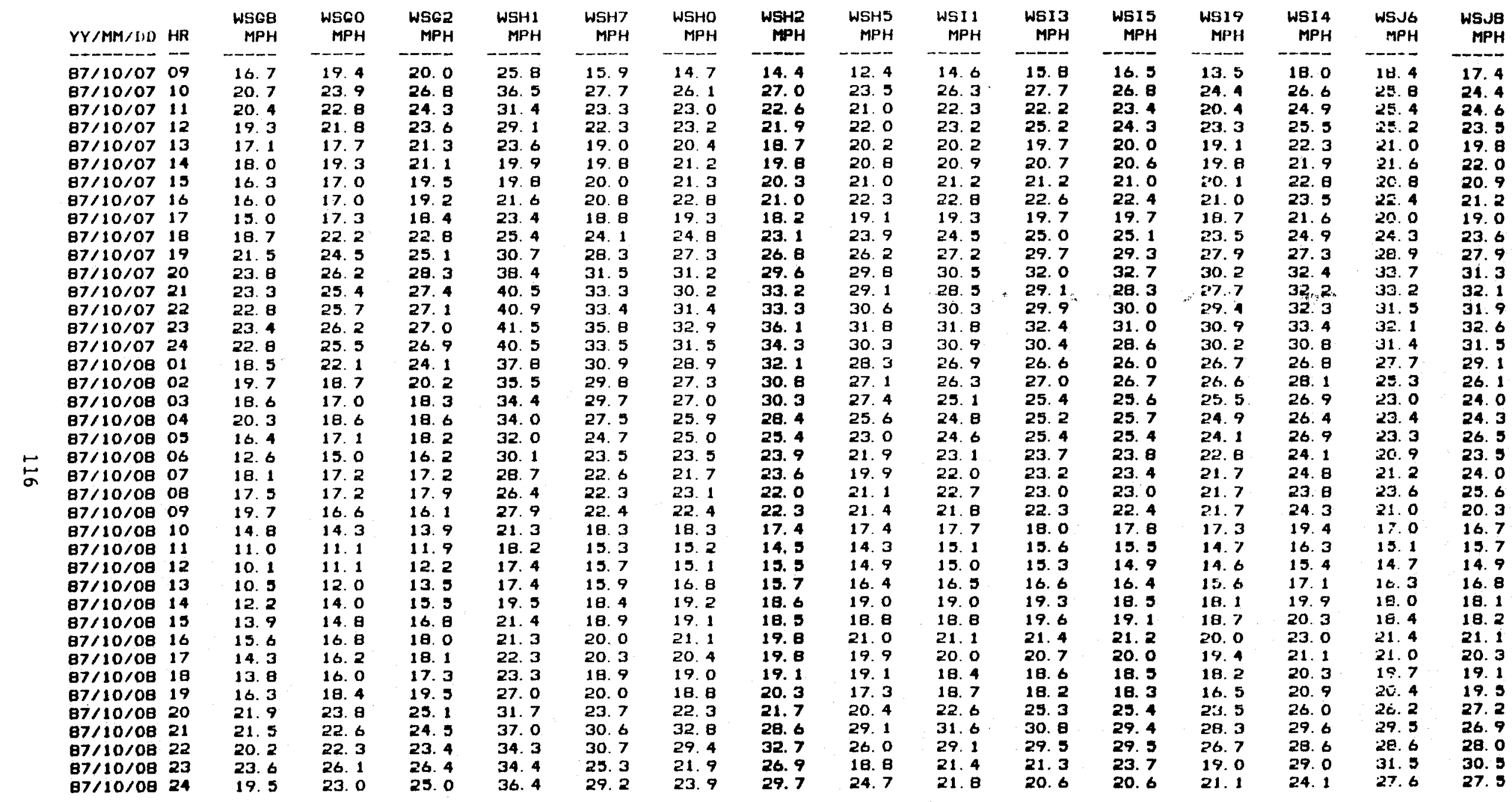


I DOE FREE FLOW DATA - JESS RANCH

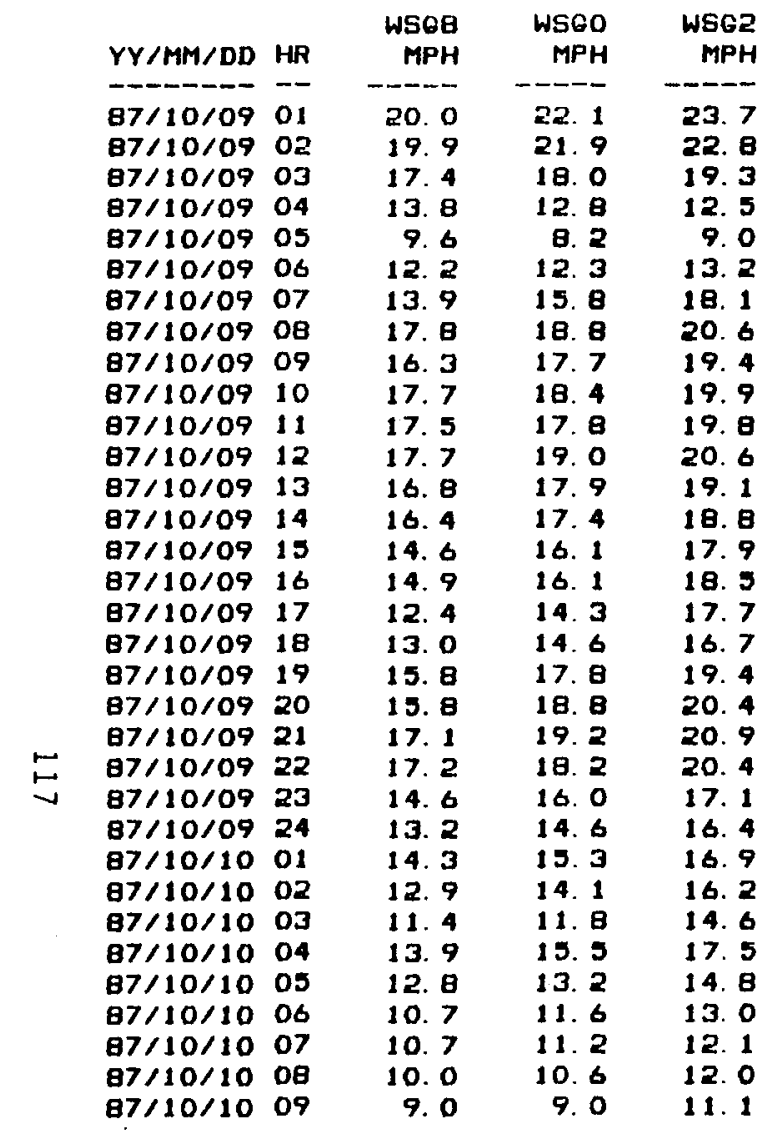

\begin{tabular}{r} 
WSH1 \\
MPH \\
\hdashline 33.4 \\
32.0 \\
34.9 \\
28.6 \\
16.9 \\
23.4 \\
24.3 \\
29.4 \\
28.7 \\
30.2 \\
28.3 \\
27.0 \\
24.9 \\
25.1 \\
22.7 \\
21.4 \\
16.0 \\
24.1 \\
24.9 \\
23.1 \\
25.9 \\
27.2 \\
27.9 \\
25.3 \\
24.9 \\
22.3 \\
19.0 \\
21.6 \\
21.6 \\
20.0 \\
21.1 \\
20.8 \\
19.3
\end{tabular}

\begin{tabular}{rr} 
WSH7 & WSHO \\
MPH & MPH \\
\hline 27.3 & -26.0 \\
25.2 & 24.1 \\
27.7 & 25.3 \\
23.2 & 21.0 \\
12.9 & 11.7 \\
19.2 & 18.0 \\
19.6 & 19.0 \\
23.1 & 22.3 \\
22.8 & 21.7 \\
24.3 & 23.5 \\
23.9 & 24.7 \\
23.5 & 24.3 \\
21.3 & 22.9 \\
21.9 & 21.6 \\
20.2 & 21.2 \\
19.3 & 20.8 \\
14.4 & 15.5 \\
16.5 & 16.1 \\
18.7 & 18.1 \\
19.9 & 21.7 \\
24.3 & 24.9 \\
24.1 & 24.5 \\
21.6 & 21.1 \\
20.3 & 19.4 \\
20.3 & 19.2 \\
18.7 & 18.1 \\
15.1 & 13.6 \\
17.0 & 16.8 \\
16.7 & 16.0 \\
16.9 & 16.8 \\
17.4 & 17.2 \\
17.9 & 17.9 \\
15.5 & 15.5
\end{tabular}

\begin{tabular}{rr} 
WSH2 & WSHS \\
MPH & MPH \\
\hline 27.3 & 25.4 \\
25.3 & 23.3 \\
28.7 & 25.8 \\
24.0 & 21.2 \\
13.2 & 11.1 \\
19.1 & 17.6 \\
19.0 & 18.0 \\
22.9 & 21.7 \\
22.8 & 21.5 \\
23.9 & 23.3 \\
23.8 & 24.5 \\
23.3 & 24.1 \\
21.6 & 23.0 \\
21.6 & 21.2 \\
20.1 & 21.0 \\
19.5 & 20.4 \\
14.5 & 15.0 \\
16.2 & 15.5 \\
18.3 & 17.5 \\
19.4 & 21.0 \\
24.0 & 24.3 \\
23.7 & 24.2 \\
21.8 & 20.9 \\
20.6 & 19.3 \\
20.4 & 18.9 \\
19.1 & 18.1 \\
15.8 & 14.0 \\
16.7 & 16.6 \\
16.5 & 15.9 \\
16.3 & 16.2 \\
17.2 & 16.7 \\
17.4 & 17.2 \\
15.2 & 14.9
\end{tabular}

\begin{tabular}{rr} 
WSI & WGI3 \\
MPH & MPH \\
\hline 24.8 & 25.3 \\
22.8 & 23.1 \\
23.7 & 23.7 \\
19.9 & 19.8 \\
11.5 & 11.8 \\
17.6 & 17.7 \\
18.4 & 18.3 \\
21.7 & 22.4 \\
20.9 & 20.8 \\
23.6 & 24.5 \\
24.8 & 25.1 \\
24.2 & 24.6 \\
22.9 & 23.1 \\
21.3 & 22.4 \\
20.8 & 20.9 \\
20.6 & 20.3 \\
15.5 & 15.7 \\
16.0 & 16.1 \\
17.9 & 18.6 \\
21.8 & 22.3 \\
24.8 & 24.9 \\
24.3 & 24.6 \\
20.9 & 20.6 \\
18.7 & 18.7 \\
18.7 & 19.3 \\
17.5 & 17.8 \\
13.0 & 12.9 \\
16.7 & 16.5 \\
15.7 & 16.0 \\
16.3 & 16.3 \\
16.5 & 16.1 \\
17.3 & 17.4 \\
14.9 & 15.2 \\
& \\
\hline 15.9
\end{tabular}

\begin{tabular}{r} 
WSI \\
MPH \\
\hdashline 24.8 \\
23.0 \\
23.7 \\
20.1 \\
12.3 \\
17.7 \\
19.4 \\
22.9 \\
20.6 \\
24.6 \\
24.9 \\
24.6 \\
22.5 \\
22.7 \\
21.3 \\
20.6 \\
15.9 \\
15.6 \\
18.5 \\
22.0 \\
25.2 \\
24.6 \\
20.8 \\
18.9 \\
19.6 \\
17.8 \\
13.2 \\
16.4 \\
16.0 \\
16.4 \\
16.1 \\
16.7 \\
14.8 \\
\end{tabular}

\begin{tabular}{rr} 
WS19 & WS14 \\
MHH & MPH \\
\hdashline 24.8 & 25.5 \\
22.3 & 25.5 \\
23.8 & 25.6 \\
20.3 & 20.6 \\
11.5 & 13.5 \\
17.4 & 19.3 \\
17.5 & 20.3 \\
21.3 & 24.6 \\
20.5 & 23.1 \\
23.5 & 27.0 \\
24.1 & 27.2 \\
23.5 & 26.4 \\
21.8 & 24.0 \\
21.4 & 24.0 \\
20.1 & 22.9 \\
19.4 & 21.7 \\
14.6 & 17.4 \\
15.6 & 16.6 \\
17.5 & 19.9 \\
20.9 & 22.8 \\
23.7 & 26.5 \\
23.7 & 26.4 \\
20.4 & 22.8 \\
16.4 & 20.8 \\
18.8 & 21.9 \\
17.6 & 19.2 \\
13.3 & 14.6 \\
16.0 & 18.0 \\
15.7 & 17.7 \\
15.5 & 17.2 \\
15.6 & 17.5 \\
16.7 & 17.2 \\
14.6 & 15.7 \\
&
\end{tabular}

\begin{tabular}{r} 
WSJG \\
MPH \\
\hline 21.1 \\
26.0 \\
24.1 \\
17.2 \\
12.0 \\
19.6 \\
19.7 \\
24.4 \\
22.7 \\
24.8 \\
25.1 \\
24.3 \\
23.7 \\
22.6 \\
21.3 \\
20.2 \\
16.5 \\
16.6 \\
20.4 \\
21.7 \\
25.3 \\
25.5 \\
21.9 \\
15.3 \\
20.3 \\
17.4 \\
13.8 \\
19.9 \\
17.2 \\
16.6 \\
15.9 \\
10.2 \\
13.5
\end{tabular}
MPH 26. 5 26. 3 16. 4 12. 4 18. 5 18. 8 24. 6 23. 2 25.9 24. 3 23. 9 22. 8 21.9 20. 8 16.8
18.3 19. 9 20. 9 24. 3 25. 9 22.9 19. 3 17.8 15. 1 19. 6 17. 9 16. 5 17. 1 13. 5 
HOURLY DATA LISTING

DOE FREE FLOW DATA - JESS RANCH

\begin{tabular}{|c|c|c|c|c|}
\hline ID & UNITS & DESCR IP & TION & \\
\hline WSJ1 & MPH & TURB INE & $J 11$ & $50-f t$ \\
\hline WSง3 & $\mathrm{MPH}$ & TURB INE & J13 & $50-f t$ \\
\hline WSK 1 & $\mathrm{MPH}$ & TUR B INE & $k 1$ & $35-f t$ \\
\hline W5K3 & $\mathrm{MPH}$ & TURB INE & $\mathrm{k} 3$ & $35-f t$ \\
\hline WSK5 & MPH & TURB INE & K5 & $35-f t$ \\
\hline WSK7 & $\mathrm{MPH}$ & TURB INE & $k 7$ & $35-f t$ \\
\hline WSK9 & MPH & TURB INE & $k 9$ & $35-f t$ \\
\hline WSKE & $\mathrm{MPH}$ & TURB INE & $K 12$ & $35-f t$ \\
\hline WSK 4 & $\mathrm{MPH}$ & TURB INE & K14 & $35-f t$ \\
\hline WSL 1 & $\mathrm{MPH}$ & TURB INE & LI & $35-f t$ \\
\hline WSL 3 & $\mathrm{MPH}$ & TURB INE & L3 & $35-f t$ \\
\hline WSL5 & $\mathrm{MPH}$ & TURBINE & $\llcorner 5$ & $35-f t$ \\
\hline WSL8 & $M P H$ & TURB INE & L8 & $35-f t$ \\
\hline WSLO & $\mathrm{MPH}$ & TURB INE & 110 & $35-f t$ \\
\hline W & $\mathrm{MPH}$ & TURB INE & $\operatorname{LI2}$ & $35-f t$ \\
\hline
\end{tabular}

NOTES:

VALUES ARE THE tO MINUTE AVERAge FOR THE PERIDD ENDING ON THE HOUR SHOWN. ALL VALUES ARE ROUNDED TO THE NEAREST DECIMAL PLACE. 
DOE FREE FLOW DATA - JESS RANCH

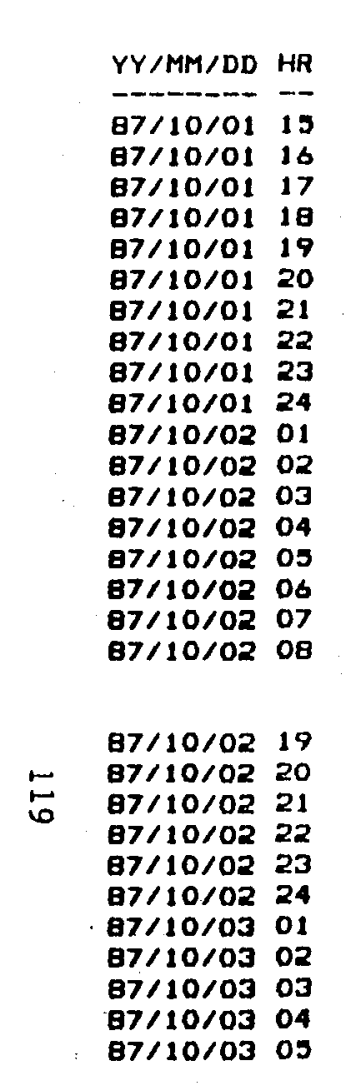

\begin{tabular}{rrrrrr} 
WSJ1 & WSJ3 & WSK1 \\
MPH & MPH & $\begin{array}{r}\text { MPH } \\
\text { WSK }\end{array}$ & $\begin{array}{r}\text { WSK5 } \\
\text { MPH }\end{array}$ & $\begin{array}{r}\text { WSK7 } \\
\text { MPH }\end{array}$ \\
\hline 23.1 & 21.7 & 19.5 & 20.0 & 20.3 & 19.9 \\
23.4 & 22.2 & 19.3 & 19.4 & 19.3 & 19.8 \\
22.2 & 21.1 & 18.1 & 18.5 & 19.3 & 19.1 \\
21.7 & 20.1 & 17.8 & 17.4 & 17.0 & 17.7 \\
26.0 & 26.1 & 20.9 & 22.3 & 22.1 & 19.8 \\
13.3 & 12.8 & 11.9 & 12.8 & 13.4 & 11.7 \\
14.7 & 14.9 & 12.6 & 13.4 & 15.4 & 14.8 \\
24.8 & 25.3 & 21.1 & 21.3 & 20.0 & 17.4 \\
24.5 & 26.9 & 23.7 & 24.2 & 21.6 & 20.8 \\
24.6 & 27.4 & 22.8 & 22.4 & 20.1 & 17.8 \\
25.0 & 25.8 & 19.9 & 18.6 & 17.4 & 16.2 \\
21.7 & 19.3 & 14.9 & 13.1 & 13.9 & 14.4 \\
10.7 & 10.8 & 9.0 & 11.5 & 15.9 & 16.7 \\
10.6 & 10.0 & 7.3 & 10.6 & 15.2 & 16.4 \\
19.4 & 14.0 & 14.1 & 9.6 & 9.8 & 12.2 \\
6.3 & 5.4 & 6.8 & 5.7 & 7.4 & 10.3 \\
2.1 & 2.7 & 3.0 & 5.1 & 8.9 & 9.3 \\
10.0 & 10.6 & 9.3 & 11.3 & 13.0 & 12.1
\end{tabular}

\begin{tabular}{rrrr} 
WSK9 & WEK2 & WSK4 \\
MPH & MPH & $\begin{array}{r}\text { WSL1 } \\
\text { MPH }\end{array}$ \\
\hdashline 22.5 & 20.9 & 23.7 & 24.3 \\
21.7 & 20.9 & 23.3 & 23.9 \\
21.1 & 20.3 & 22.3 & 22.3 \\
20.3 & 18.4 & 21.4 & 22.6 \\
20.9 & 19.6 & 21.0 & 24.2 \\
12.3 & 12.4 & 12.4 & 14.4 \\
16.1 & 16.2 & 18.7 & 19.0 \\
19.5 & 17.9 & 20.5 & 22.5 \\
22.5 & 21.7 & 23.4 & 25.3 \\
20.1 & 18.7 & 21.6 & 23.6 \\
20.5 & 17.0 & 21.8 & 25.2 \\
18.7 & 15.3 & 19.6 & 22.0 \\
21.1 & 18.7 & 22.9 & 24.2 \\
20.1 & 18.3 & 22.4 & 23.2 \\
17.0 & 14.0 & 19.0 & 20.4 \\
14.4 & 12.4 & 16.5 & 17.4 \\
11.9 & 11.0 & 13.3 & 13.4 \\
12.5 & 13.0 & 14.3 & 13.7
\end{tabular}

$\begin{array}{rrrr}11.1 & 10.1 & 8.6 & 8.5 \\ 11.3 & 10.8 & 7.6 & 8.3 \\ 13.7 & 12.8 & 11.2 & 11.1 \\ 10.1 & 8.2 & 8.2 & 8.3 \\ 13.0 & 10.5 & 8.2 & 9.9 \\ 13.1 & 8.6 & 8.7 & 8.8 \\ 10.0 & 8.9 & 1.7 .3 & 7.5 \\ 10.2 & 10.5 & 10.2 & 11.9 \\ 11.5 & 11.5 & 10.7 & 11.8 \\ 5.0 & 4.1 & 4.9 & 4.2 \\ 7.8 & 7.5 & 7.7 & 9.2\end{array}$

9.0
9.0
10.7
9.5
9.2
9.0
9.9
13.3
13.5
7.0
11.1

7.
9.0
9.7
9.4
9.2
8.
11.1
12.8
12.7
8. 0
11.0

9. 5
10.6
11.4
11.4
11.4
11.2
13.3
14.6
10.3
10.8
12.5

B. 2
10.0
10.4
10.6
9.9
10.5
12.9
13.5
13.3
9.0
11.4

B. 6
11.5
12.5
12.6
12.7
12.7
15.1
15.1
15.2
11.5
13.2

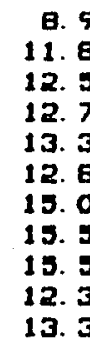

6. 9

1. 8

12. 7

13. 3

2.

5. 5

อ. 5

13. 3

\begin{tabular}{r} 
WELJ \\
MPH \\
\hdashline 25.3 \\
25.2 \\
22.9 \\
24.1 \\
24.6 \\
14.9 \\
20.0 \\
23.9 \\
26.6 \\
25.5 \\
26.8 \\
23.4 \\
25.4 \\
24.6 \\
21.6 \\
16.6 \\
14.0 \\
14.5
\end{tabular}

WEIL 5
NIII
26.5
26.0
23.9
23.9
25.0
25.3
14.8
20.9
25.0
27.5
27.0
28.4
23.8
26.1
26.1
22.8
19.1
14.2
15.2

9. 2

12. 2

4. 3

4.3
12.3
13.0

13. 5

13.

13. 3

15.7

15. 5

12. 7

13. 0

14.

13. 9

16.

16. 0

13. 9

13. 2

\begin{tabular}{r} 
WSL \\
MPH \\
\hline 24.1 \\
24.3 \\
21.9 \\
22.9 \\
23.9 \\
12.9 \\
19.4 \\
22.4 \\
25.1 \\
24.3 \\
25.7 \\
22.3 \\
24.7 \\
24.0 \\
21.1 \\
17.9 \\
12.9 \\
13.6
\end{tabular}

B.
11.4
12.2
13.0
13.6
13.0
15.1
14.9
14.7
11.9
12.9

9. 3
12.3
12.9
13.4
14.5
14.1
15.9
10.0
15.8
13.1
13.6

MPH

7

25. 8

25. 3

25. 3

24.6

24. 2

13. 8

23. 6

28. 8

20. 2

27. 8

23. 1

23. 6

2. 2

18. 5

14. 0

14. 7

26.2

26. 0

25. 7

14. 2

24.9

27.9

29.3

24.

27.2
27.

24.4
19.6

19.6
14.4

14.

10. 0

13. 1
13.6

14.3
15.9

15.

17. 3

16. $?$

16.5
13.4

13. 7

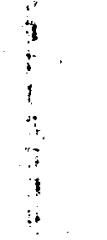


DOE FREE FLOW DATA - JESS RANCH

\begin{tabular}{|c|c|c|c|c|c|c|c|c|c|c|c|c|c|c|c|c|}
\hline$Y Y / M M / D D$ & $H R$ & $\begin{array}{c}\text { WSJ1 } \\
\text { MPH }\end{array}$ & $\begin{array}{r}\text { WSJ3 } \\
\text { MPH }\end{array}$ & $\begin{array}{c}\text { WSK } 1 \\
\text { MPH }\end{array}$ & $\begin{array}{r}\text { WSK3 } \\
\text { MPH }\end{array}$ & $\begin{array}{l}\text { WSKS } \\
\text { MPH }\end{array}$ & $\begin{array}{r}\text { WSK7 } \\
\text { MPH }\end{array}$ & $\begin{array}{c}\text { WSK9 } \\
\text { MPH }\end{array}$ & $\begin{array}{r}\text { WSK2 } \\
\text { MPH }\end{array}$ & $\begin{array}{r}\text { WSK4 } \\
\text { MPH }\end{array}$ & $\begin{array}{c}\text { WSL1 } \\
\text { MPH }\end{array}$ & $\begin{array}{r}\text { WSL3 } \\
\text { MPH }\end{array}$ & $\begin{array}{r}\text { WSL : } \\
\text { MPIH }\end{array}$ & $\begin{array}{c}\text { WELB } \\
\text { MPH }\end{array}$ & $\begin{array}{r}\text { WSLO } \\
\text { MPH }\end{array}$ & $\underset{\text { MPH }}{\text { WBL2 }}$ \\
\hline $87 / 10 / 07$ & 09 & 17.2 & 15.6 & 16. 0 & 17. 0 & 16. 7 & 16. 0 & 19. 0 & 15. 3 & 17.7 & 22.4 & 25.4 & .99. 4 & 19.1 & 23.9 & 26.9 \\
\hline $87 / 10 / 07$ & 10 & 23.6 & 23.2 & 22.0 & 23. 2 & 24.8 & 25. 4 & 26. 5 & 25.6 & 28. 4 & 30. 4 & 32. 2 & 34.2 & 30.0 & 32.8 & 33. 8 \\
\hline $87 / 10 / 07$ & 11 & 24.3 & 23. 9 & 21. $B$ & 22. 3 & 22. 1 & 22. 9 & 25. 6 & 23. 1 & 27. 2 & 29.1 & 30.8 & 32.2 & 28. 7 & 30.7 & 32. 1 \\
\hline $87 / 10 / 07$ & 12 & 23. $\theta$ & 23. 6 & 20.7 & 21.7 & 22.4 & 22. 1 & 23.7 & 22.8 & 25.6 & 27.7 & 29.5 & 29. 7 & 27. 3 & 28.7 & 29.9 \\
\hline $87 / 10 / 07$ & 13 & 21.3 & 21. 3 & 18. 5 & 1日. 9 & 21. 3 & 20.4 & 22.6 & 21.0 & 24. 3 & 25. 6 & 26.6 & 27.5 & 24. 8 & $2 \dot{20.7}$ & 27.7 \\
\hline $87 / 10 / 07$ & 14 & 22. 5 & 22.4 & 19.7 & 19.7 & 20.7 & 20.7 & 22. 1 & 21.4 & 23.9 & 24.6 & 26.0 & 26.9 & 24. $日$ & $2 \dot{\varepsilon} .2$ & 26.7 \\
\hline $87 / 10 / 07$ & 15 & 21.5 & 21.5 & 18. 7 & 18. 7 & 19. 4 & 19. 8 & 21. 1 & 20. 5 & 23. 2 & 23. 5 & 24.4 & 25.5 & 23. 5 & 24.9 & 25.6 \\
\hline $87 / 10 / 07$ & 16 & 22. 1 & 21.2 & 18. 3 & 1日. 2 & 19. 3 & 19. 3 & 21.6 & 20.2 & 23.2 & 23. 8 & 25. 0 & 25.8 & 23.6 & 25.2 & 25. 9 \\
\hline $87 / 10 / 07$ & 17 & 19.6 & 19. 1 & 13. 2 & 17.1 & 18. 0 & 17.6 & 18. 8 & 18. 8 & 20.3 & 21.3 & 23.5 & 24.2 & 21.8 & 23.5 & 23.9 \\
\hline $87 / 10 / 07$ & 18 & 24.4 & 24. 7 & 18. 3 & 21.7 & 21.9 & 22.5 & 23.0 & 23. 4 & 25.2 & 25.6 & 27.2 & 29.0 & 25.9 & 27.7 & 29.6 \\
\hline $87 / 10 / 07$ & 19 & 28. 2 & 29.0 & 23. 3 & 25.1 & 24.3 & 24. 1 & 25. 2 & 24. 8 & 28.7 & 30.6 & 31.2 & 32.3 & 30.0 & 31.5 & 32.7 \\
\hline $07 / 10 / 07$ & 20 & 32. 3 & 31.4 & 26. 3 & 27.6 & 27. 3 & 27.9 & 29.3 & 29.5 & 32.7 & 33.4 & 35. 9 & it6. 4 & 34. 2 & 36.7 & 35.5 \\
\hline $87 / 10 / 07$ & 21 & 33. 0 & 31.0 & 27.2 & 26.7 & 25.9 & 27.0 & 29. $\theta$ & 2日. 0 & 32. 3 & 32.5 & 34.6 & 36.2 & 33. 0 & $3 * 3$ & 36.3 \\
\hline $87 / 10 / 07$ & 22 & 31.8 & 31.7 & 28. 1 & 27.0 & 2b. 1 & 25.4 & 28. 2 & 26.6 & 30.5 & 31.5 & 33. 3 & 35.1 & 31.7 & 34.3 & 34. 8 \\
\hline $87 / 10 / 07$ & 23 & 32.6 & 31.5 & 27.9 & 28.0 & 27.3 & 25. 9 & 29. 2 & 27.3 & 31.8 & 31.6 & 34.6 & 36.2 & 32.7 & 35. 6 & 35. 5 \\
\hline $87 / 10 / 07$ & 24 & 32.0 & 29. 4 & 25. 7 & 27.3 & 26. 2 & 25.9 & 29.6 & 27.6 & 31.7 & 31.2 & 33. 1 & 34.9 & 31.7 & 33. 8 & 34. 8 \\
\hline $87 / 10 / 00$ & 01 & 28.7 & 2. 2 & 24. 1 & 23. 2 & 23. 0 & 21.7 & 25.9 & 22. 6 & 27.1 & 28. 3 & 30.5 & 3i2. 0 & 28. 8 & उज̄. 9 & 31.8 \\
\hline $87 / 10 / 08$ & 02 & 25. 3 & 2日. 3 & 25. 1 & 25.7 & 21.5 & 17.6 & 18. 1 & 18. 1 & 18. 1 & 23. $\theta$ & 26.6 & $\therefore$ (日. 8 & 24.5 & $\therefore<.9$ & 28. 3 \\
\hline $87 / 10 / 08$ & 03 & 23. 4 & 25. 8 & 23. 8 & 25. 1 & 20.0 & 15. 4 & 17.4 & 16. 4 & 17.1 & 23. 0 & 24. 5 & 26.7 & 22.7 & 24.7 & 26. 5 \\
\hline $87 / 10 / 08$ & 04 & 23. 9 & 25. 8 & 22. 9 & 24.4 & 22.0 & 17. 2 & 17.6 & 1日. 4 & 18. 2 & 19.6 & 21.9 & 23.0 & 20.4 & 22.0 & 22. 7 \\
\hline $87 / 10 / 08$ & 05 & 25.9 & 27. 2 & 23. 8 & 21.7 & 1日. 1 & 16. 2 & 19.5 & 17.3 & 20.5 & 23. 0 & 24.0 & 25.0 & 2.3. 1 & 24.3 & 24. $\theta$ \\
\hline $87 / 10 / 0 \theta$ & 06 & 22.7 & 23. 7 & 20.4 & 17.6 & 14.9 & 14.9 & 19. 1 & 15. 9 & 20.4 & 22.1 & 23. 5 & 24.2 & 22. 5 & 23.7 & 24.0 \\
\hline $87 / 10 / 08$ & 07 & 23. 1 & 25. 3 & 22. 7 & 22.8 & 19. 3 & 15. 3 & 15. 2 & 16. 0 & 16. 3 & 18.9 & 21.1 & 21.6 & 19.9 & 21.2 & 21.5 \\
\hline $87 / 10 / 08$ & 08 & 25.3 & 25. 4 & 22. 3 & 22. 5 & 18.9 & 15. 9 & 16. 1 & 16. 4 & 17.3 & 18. 6 & 19.8 & 20.5 & 19.0 & 20.0 & 19. 9 \\
\hline $87 / 10 / 08$ & 09 & 21.1 & 22. 4 & 20.1 & 22. 3 & 21.1 & 16. 1 & 14. 8 & 18. 0 & 16. 2 & 15. 9 & 16.7 & 19.0 & 15.8 & 17.2 & 19. 1 \\
\hline $87 / 10 / 08$ & 10 & 17.4 & 18. 8 & 17. 0 & 18. 4 & 16. 8 & 13. 5 & 12. 5 & 14.5 & 13. 7 & 13. 5 & 14. $B$ & 16.5 & 13.9 & 15.2 & 16.6 \\
\hline $87 / 10 / 08$ & 11 & 15.5 & 14. 9 & 13. 9 & 13. 8 & 12. 9 & 11.1 & 12.6 & 12. 2 & 13. 6 & 14. 8 & 16.6 & $1 \% .6$ & 15. 3 & le. 7 & 18. 1 \\
\hline $87 / 10 / 00$ & 12 & 14.9 & 14.6 & 13. 6 & 13. 5 & 12. 9 & 11.6 & 13. 2 & 12. 7 & 14. 3 & 15. 6 & 17. 2 & 10. 3 & 16. 1 & 17.4 & 18. 6 \\
\hline $87 / 10 / 08$ & 13 & 16.日 & 15. 5 & 14. 3 & 13. 6 & 14.4 & 14. 0 & 16.0 & 15. 0 & 17. 2 & 18. 4 & 19. 2 & 20. 0 & 18. 1 & 19. 3 & 20. 4 \\
\hline $87 / 10 / 00$ & 14 & 18. 1 & 17.9 & 15. 6 & 15. 7 & 15. 7 & 15. 6 & 17.4 & 16. 7 & 18. 7 & 19.8 & 21.0 & 21. $B$ & 19.8 & 21.1 & 22. 2 \\
\hline $87 / 10 / 00$ & 15 & 1日. 2 & 18. 2 & 15. 7 & 16. 3 & 17. 1 & 16. 7 & 18. 2 & 17.5 & 19.6 & 20.9 & 22.0 & 22.6 & 20.9 & 22. 0 & 23. 0 \\
\hline $87 / 10 / 00$ & 16 & 21.2 & 20.9 & 17.7 & 18. 3 & 18.6 & 18. 0 & 19.9 & 18.9 & 21.6 & 22.9 & 24.3 & 24.9 & 23. 0 & 24.3 & 25. 0 \\
\hline$\theta 7 / 10 / 08$ & 17 & 20.4 & 19. 8 & 17.0 & 17.6 & 18. 1 & 17.6 & 19.4 & 19. 1 & 20.9 & 20.9 & 23. 2 & 24.4 & 22.1 & 23.8 & 24.6 \\
\hline $87 / 10 / 00$ & 18 & 19.8 & 19. 2 & 15. 2 & 17. 4 & 17.1 & 16. 2 & 18. 9 & 17.6 & 20.0 & 19.7 & 21.5 & 23. 5 & 19. 9 & 22. 2 & 24. 1 \\
\hline $87 / 20 / 00$ & 19 & 19.6 & 19. 9 & 15.5 & 18. 5 & 18. 8 & 19. 8 & 21.5 & 20. 1 & 23.7 & 25.0 & 24.9 & 25. 1 & 24.6 & 24.7 & 26.2 \\
\hline $87 / 10 / 00$ & 20 & 27.2 & 28. 3 & 24.3 & 24.5 & 25. 3 & 25.6 & 27. 0 & 26.7 & 30.7 & 30.4 & 29.8 & 32.6 & 29.7 & 31.6 & 33. 8 \\
\hline $87 / 10 / 08$ & 21 & 27.5 & 27. 2 & 23. 1 & 24. 5 & 24.0 & 24. 4 & 25. 2 & 25. 4 & 28.9 & 29.8 & 28.6 & 30.2 & $2 \theta .1$ & 29.3 & 31.1 \\
\hline$\theta 7 / 10 / 08$ & 22 & 28. 3 & 27.0 & 23.6 & 23. 4 & 23. $\theta$ & 24.4 & 25. 7 & 25. 2 & 28. 9 & 29.4 & 30.4 & 32. 2 & 29.6 & 31.4 & 32. 0 \\
\hline $87 / 10 / 08$ & 23 & 30.5 & 31.1 & 26.7 & 28.0 & 26. 3 & 24. 8 & 28. 0 & 2b. 2 & 30.8 & 31.3 & 32.6 & 35.6 & 31.7 & 34.6 & 35. 7 \\
\hline $87 / 10 / 08$ & 24 & 28. 3 & 27. 3 & 22. 7 & 23. 1 & 22. 3 & 21.8 & 24.6 & 22.7 & 26.1 & 28. 1 & 31.3 & 33. 3 & 28.5 & 31.6 & 33. $=$ \\
\hline
\end{tabular}


DOE FREE FLOW DATA - JESS RANCH

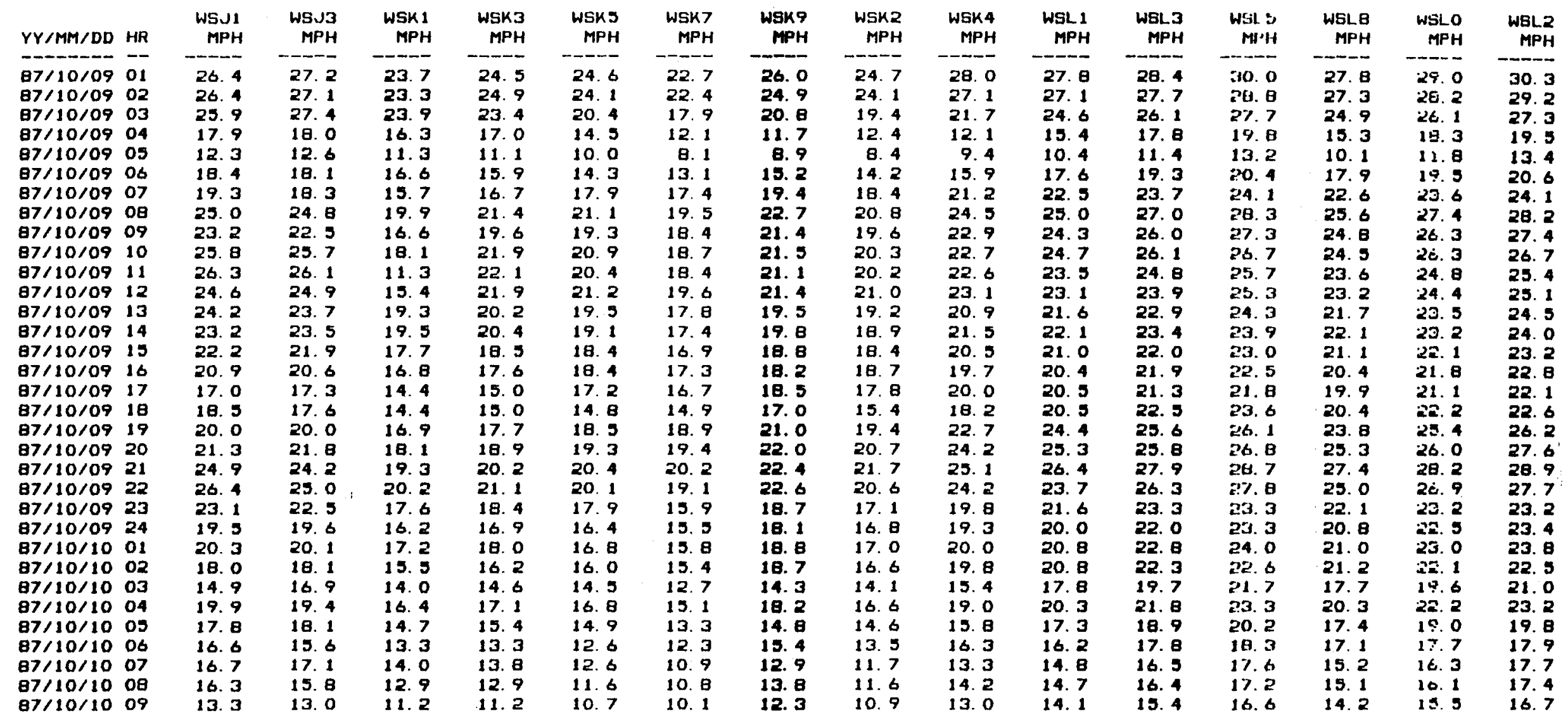




\section{HOURLY DATA LISTING}

DOE FREE FLOH DATA - JESS RANCH

\begin{tabular}{|c|c|c|c|c|}
\hline \multirow{2}{*}{$\frac{\text { ID }}{\text { WEM2 }}$} & \multirow{2}{*}{$\frac{\text { UNITS }}{\mathrm{MPH}}$} & \multicolumn{2}{|c|}{ DESCR IPT I DN } & \multirow[b]{2}{*}{$35-f t$} \\
\hline & & TURB INE & M2 & \\
\hline WSM4 & $\mathrm{MPH}$ & TURB INE & M4 & $35-f t$ \\
\hline WSMS & $\mathrm{MPH}$ & TURBINE & Mb & $35-f t$ \\
\hline WSMB & MPH & TURBINE & MB & $35-f t$ \\
\hline WEMS & $\mathrm{MPH}$ & TURBINE & $M 9$ & $35-f t$ \\
\hline WSM1 & $\mathrm{MPH}$ & TURB INE & M1 1 & $35-f t$ \\
\hline WSM3 & $\mathrm{MPH}$ & TURB INE & $\mathrm{MIa}$ & $35-f t$ \\
\hline WSN1 & MPH & TURB INE & NI & $35-f t$ \\
\hline WSNA & MPH & TURBINE & N4 & $35-p t$ \\
\hline WSN & $\mathrm{MPH}$ & TURB INE & NG & $35-p t$ \\
\hline WBNE & MPH & TURB INE & NB & $35-f t$ \\
\hline
\end{tabular}

WOTES:

VALUES ARE THE 60 MINUTE AVERAgE FOR THE PERIOD ENDING ON THE HOUR SHOWN.

ALL VAlUes aRe ROUNDED TD THE NEAREST dECIMAL PLACE. 
DOE FREE FLOW DATA - JESS RANCH

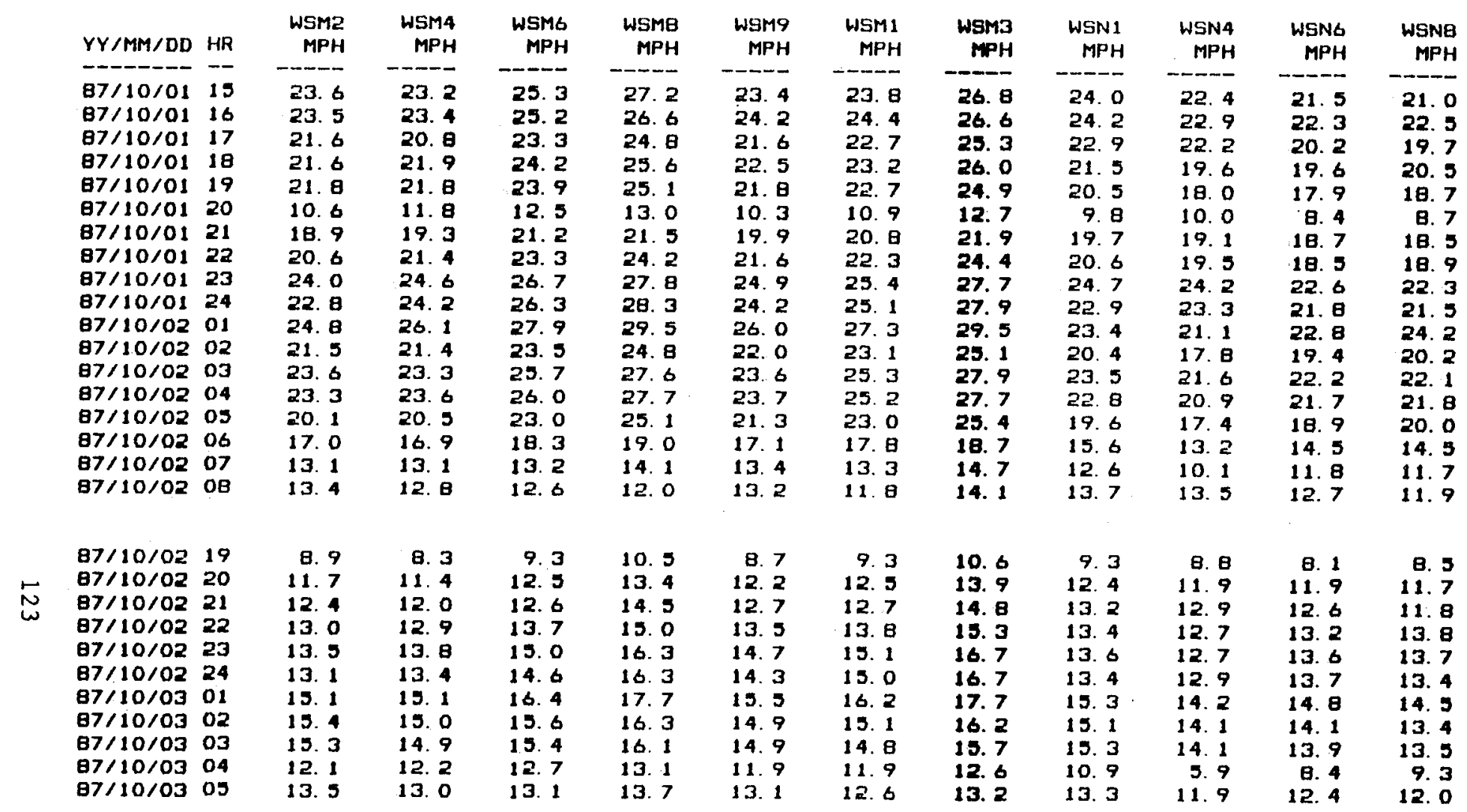


DOE FREE FLOW DATA - JESS RANCH

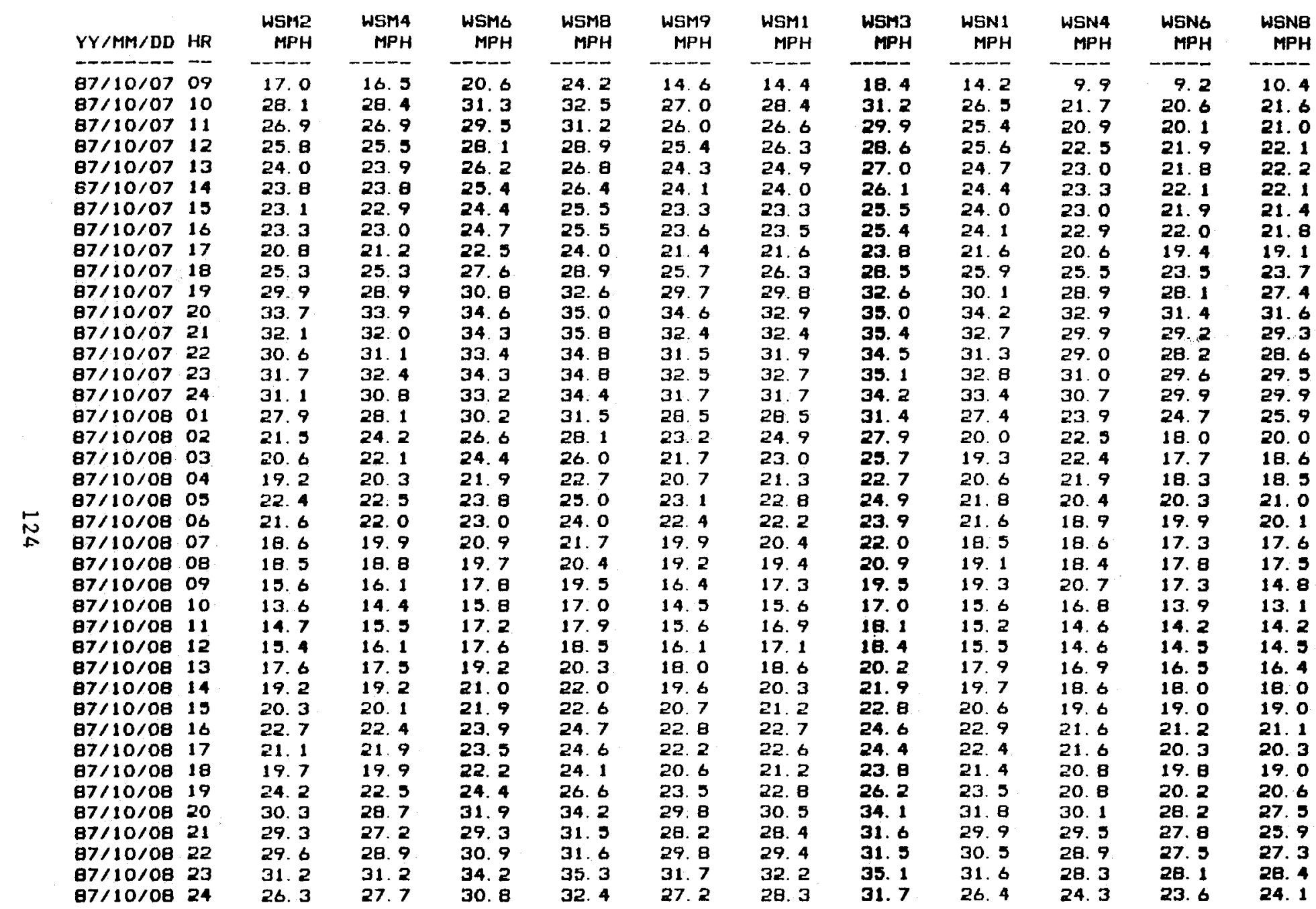


DDE FREE FLOW DATA - JESS RANCH

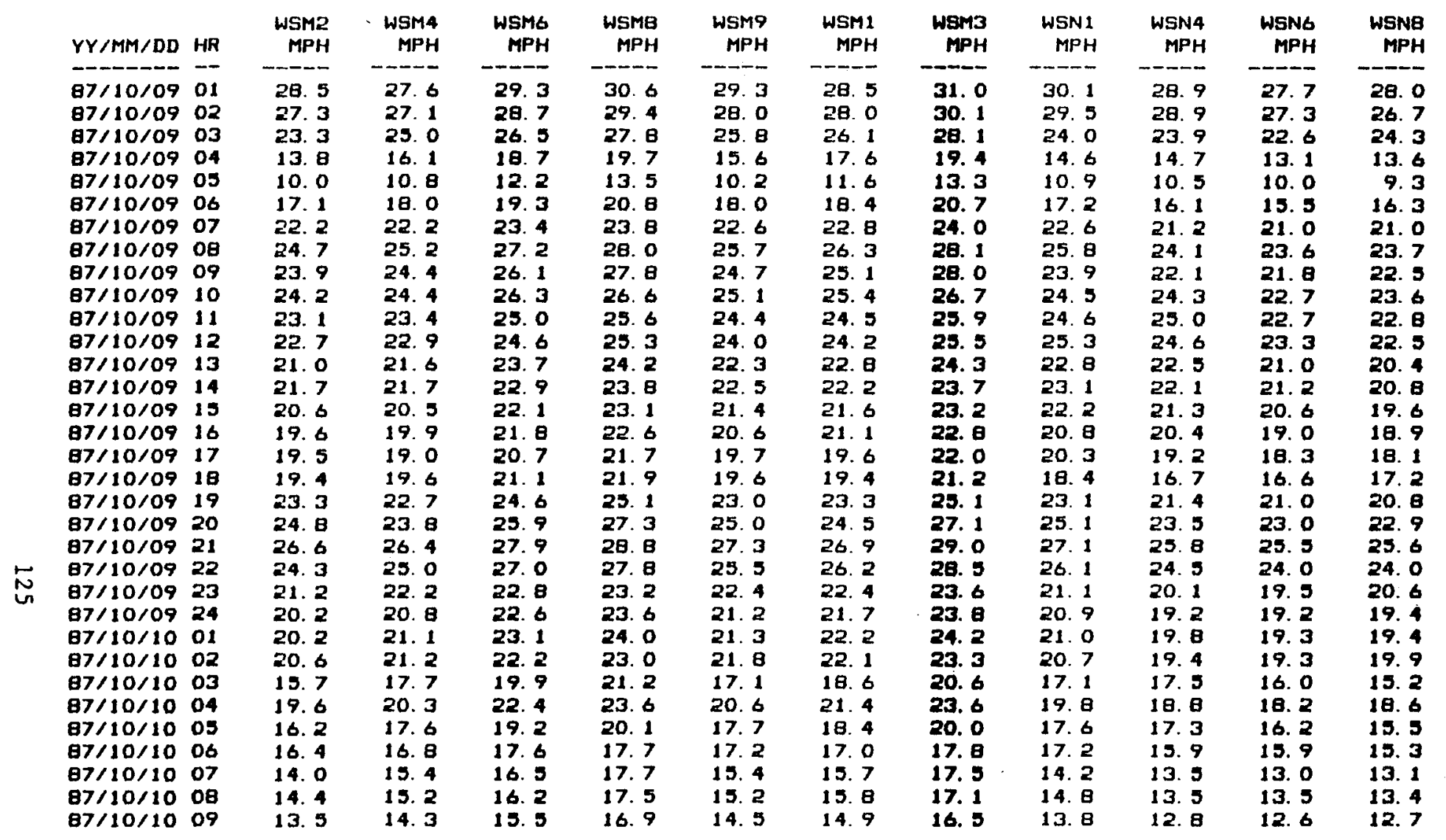


APPENDIX D

Diurnal Mean Speed Summaries 
DIURMAL SUMMARY BY PARAMETER

DOE FREE FLOW DATA - SOUZA RANCH

$09 / 10 / 87-09 / 14 / 87$

\begin{tabular}{|c|c|c|c|}
\hline HOUR & $\begin{array}{r}\text { WS13 } \\
\text { MPH }\end{array}$ & $\begin{array}{l}\text { WS12 } \\
\text { MPH }\end{array}$ & $\begin{array}{l}\text { WSE7 } \\
\text { MPH }\end{array}$ \\
\hline$\cdots-1$ & -- & $-\infty-$ & $\cdots$ \\
\hline $\begin{array}{l}1 \\
2\end{array}$ & $\begin{array}{l}29.5 \\
26.9\end{array}$ & $\begin{array}{l}28.0 \\
26.0\end{array}$ & $\begin{array}{l}27.9 \\
26.7\end{array}$ \\
\hline 3 & 25. 5 & 24.5 & 24.5 \\
\hline 4 & 24.5 & 23.6 & 24. 2 \\
\hline 5 & 24.6 & 23.6 & 24.3 \\
\hline 6 & 24.8 & 23. 9 & 24. 0 \\
\hline 7 & 23.7 & 22.6 & 22. 3 \\
\hline 8 & 23.7 & 22. 6 & 21.9 \\
\hline 9 & 23.4 & 22. 2 & 22. 1 \\
\hline 10 & 22.6 & 21. 4 & 21. 1 \\
\hline 11 & 19.6 & 1日. 5 & 18. 8 \\
\hline 12 & 18. 3 & 17.4 & 16. 8 \\
\hline 13 & 18. 3 & 17.6 & 17. 4 \\
\hline 14 & 18. 8 & 17.9 & 17.7 \\
\hline 15 & 20.6 & 19. 1 & 19.6 \\
\hline 16 & 20.7 & 19. 5 & 19.7 \\
\hline 17 & 21.3 & 20.0 & 20. 2 \\
\hline 18 & 24.8 & 23. 2 & 22. 3 \\
\hline 19 & 27.6 & 25.9 & 24. 1 \\
\hline 20 & 32.8 & 31.2 & 28. 8 \\
\hline 21 & 34.5 & 33. 0 & 32. 5 \\
\hline 22 & 32. 4 & 31.0 & 31.5 \\
\hline 23 & 30.7 & 29.3 & 29. 2 \\
\hline 24 & 31.3 & 29.6 & 28. 3 \\
\hline MEAN & 25. 1 & 23. 9 & 23. 7 \\
\hline
\end{tabular}

\begin{tabular}{|c|c|c|c|c|}
\hline $\begin{array}{c}\text { W526 } \\
\text { MPH }\end{array}$ & $\begin{array}{r}\text { WD } 13 \\
\text { DEG }\end{array}$ & $\begin{array}{c}\text { WSE9 } \\
\text { MPH }\end{array}$ & $\begin{array}{c}\text { WSD2 } \\
\text { MPH }\end{array}$ & $\begin{array}{r}\text { WSD4 } \\
\text { MPH }\end{array}$ \\
\hline 0 & 6. 6 & 3. 5 & 29.0 & 28. \\
\hline & .7 & . 8 & 27.4 & 27.0 \\
\hline 6 & 2. 5 & 7. 6 & 25. 5 & 24. 6 \\
\hline 2 & 5. 8 & 3. 9 & 23.9 & 23.9 \\
\hline 3 & .8 & . 3 & 24.0 & 24. 5 \\
\hline 9 & 22.4 & 3. 8 & 24.2 & 23.9 \\
\hline 1 & 5.9 & 2. 3 & 23. 2 & 22. 2 \\
\hline 8 & 15. 9 & 1.9 & 22. 1 & 21.8 \\
\hline 2. 2 & 226.4 & 2. 3 & 22. 4 & 22. 1 \\
\hline .2 & 227.0 & 21.6 & 21.5 & 20.9 \\
\hline 0 & 220.7 & 9.1 & 19.3 & 18. 8 \\
\hline .0 & 227. 1 & 7.3 & 17.3 & 16.7 \\
\hline 17. 5 & 224. 0 & 7. 8 & 17. 8 & 17. 3 \\
\hline 17.9 & 230.7 & 8. 5 & 18. 4 & 17.6 \\
\hline 19.5 & 236.9 & 20.5 & 20.2 & 19. 1 \\
\hline 19.7 & 236.4 & 21. 3 & 21.1 & 20. 1 \\
\hline 20.2 & 231.5 & 21.2 & 21.1 & 20.5 \\
\hline 3 & 229.2 & 23. 6 & 23. 4 & 22. 8 \\
\hline 23. 9 & 230. 8 & 25. 2 & 25. 3 & 24.5 \\
\hline 3 & 229.7 & 29. 8 & 30.0 & 28.8 \\
\hline 32. 0 & 229. 2 & 32.4 & 32.2 & 31.7 \\
\hline & 227. 0 & 31.6 & 31.9 & 31.4 \\
\hline 29.2 & 225. 4 & 29. 4 & 29.0 & 28.8 \\
\hline & 229.5 & 28. 6 & 2日. 2 & 27. \\
\hline & $c^{\prime}$ & 24 & 24.2 & 23. \\
\hline
\end{tabular}

VAL ID

HRS

94

94

94

94

94

94

94

94

NAME SITE LOCATION:

WS12 SITE $5-13$ 35-ft

WSES BITE S-27 35-ft

WS29 SITE S-29 50-ft

WSD4 TURBINE D4

WSD7 TURBINE DT

WSDT TURBINE D?

WSD3 TURBINE D1

WSE4 TURBINE E4

WSEO TURBINE E10
WSG7 TURBINE G7

WSES TURBINE ES

WSE3 TURBINE E14

WSDG WSD7

MPH

$\mathrm{MPH}$

27. 7

28. 9

24. 8 25.

24. 5 24. 1

$\begin{array}{ll}24.9 & 24.1 \\ 23.9 & 24.4\end{array}$

22. 4 23. 2

21. 9 22. 3

22. 2 22. 0

20. 4 20.6

16.4 16. 5

16. 617.0

17. 117.5

18. 219.0

$\begin{array}{ll}19.1 & 19.7 \\ 19.8 & 20.2\end{array}$

$\begin{array}{ll}19.8 & 20.2 \\ 21.8 & 22.4\end{array}$

23. 824.4

28. 1 28. 9

30. 531.2

30. 2 31. 1

$\begin{array}{ll}28.0 & 28.6 \\ 27.6 & 27.7\end{array}$

27. $6 \quad 27.7$

23. 3 23. 6

32.
31.
28.
28.
28.
27.
25.
25.
25.
23.
21.
19.
19.
20.
21.
22.
23.
25.
28.
33.
36.
35.
33.
32.
-1.
27.

32. 3 33. 3

28. 5 29.

29.9
28.9

29.6

27.8 28. 3

25. 7 "27. 0

25. 7 26. 1

26. 4

21. 4

19. 4

19. 519.7

20. 120.1

21. 81.6

22. 5

25. 6

28. 3

33. 3

34. 9

33. 1

32. 5

94

94

94

\begin{tabular}{l} 
WSE2 \\
MPH \\
\hline 30.7 \\
29.5 \\
28.1 \\
26.2 \\
27.3 \\
26.2 \\
25.3 \\
24.4 \\
25.0 \\
23.0 \\
20.1 \\
18.6 \\
18.6 \\
19.1 \\
20.7 \\
21.5 \\
22.1 \\
24.3 \\
27.1 \\
31.9 \\
32.9 \\
32.7 \\
31.1 \\
30.0 \\
$3-1$ \\
25.8
\end{tabular}

MPH

27.9

26. 5

26. 0

23. 5

24.6

$3^{\prime \prime \prime} 247$

0 22. 6

21. 6

18. 7

17. 4

17.2

17.8

19. 9

20. 5

22. 7

29. 9

30. 3

30. 3

28. 7

28. 2

23. 8
27. 530.3

25. 0

23. 8

24. 0

24. 1

22. 5

2द. 9
22. 1

19. 3

18. 1

17. 5

18. 2

19. 8

20. 2

25. 1

25. 4

50.

30. 5

ars 0

26. 9

24. 0
29. 7

27. 4

25. 9

25.6

24. 3

23. 5

23. 8

19. 4

17. 3

17. 6

17. 8

19. 9

20. 7

25.

30. 2

31. 9

31. 7

29. 8

28. 8

24. 8
$M P H$

32.5

25.

25. 3

2.3. 9

23. 1

2. 1

21. 6

20. 9

18. 3

17. 0

10. 7

17.

19. 8

20. 1

2.2. 1

2․ 4

29. 1

27. 6

27. 2

2.3. 1
NSG7
$\mathrm{MPH}$

7

26. 0

24.8
23.5

23. 5

2. 8

22. 5

21.3
20.1

17. 2

16. 0

16. 4

17. 3

17. 8

21. 7

23. 9

28.7
31.6

30.4

28. 4

28. 8

23. 0 
DIURNAL SUMMARY BY PARAMETER

DUE FREE FLOW DATA - SUUZA RANCH

$09 / 10 / 87-09 / 14 / 87$

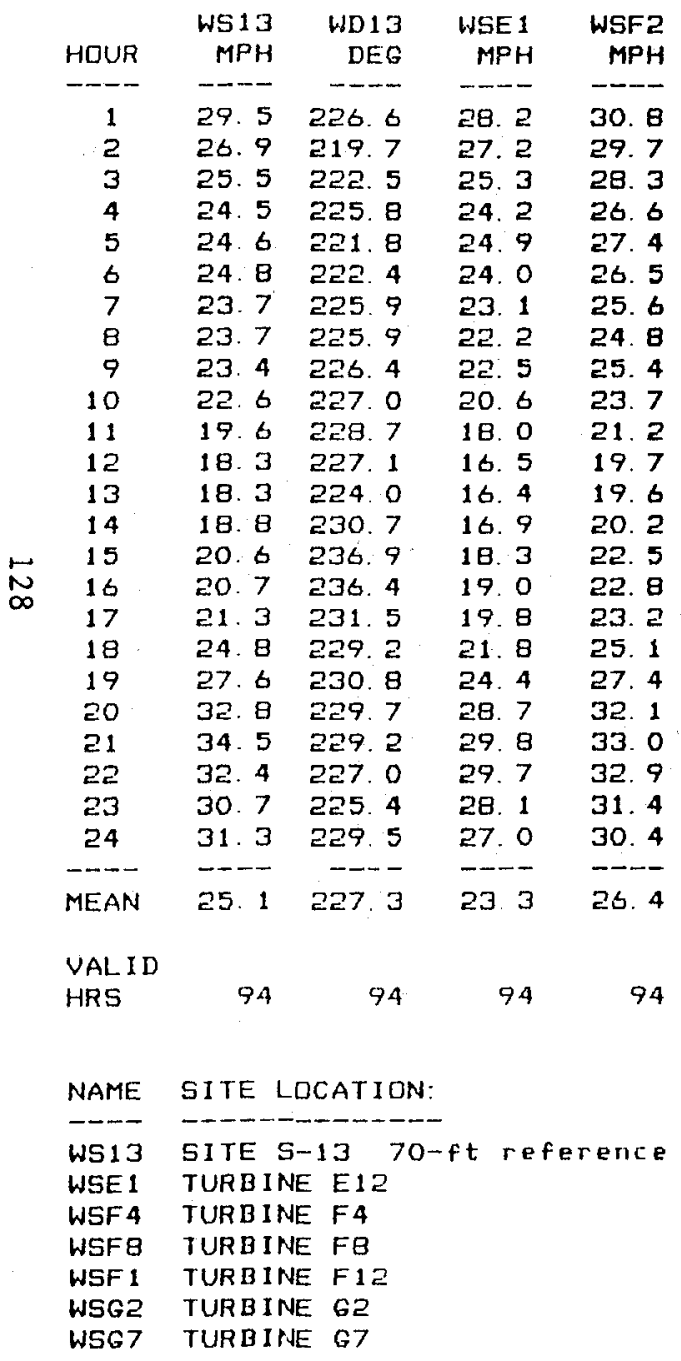

\begin{tabular}{|c|c|c|c|c|c|c|c|c|c|}
\hline $\begin{array}{r}\text { WSF } 4 \\
\text { MPH }\end{array}$ & $\begin{array}{l}\text { WSFG } \\
\text { MPH }\end{array}$ & $\begin{array}{c}\text { WSFB } \\
\text { MPH }\end{array}$ & $\begin{array}{l}\text { WSFO } \\
\text { MPH }\end{array}$ & $\begin{array}{l}\text { WSF } 1 \\
\text { MPH }\end{array}$ & $\begin{array}{l}\text { WSF } 3 \\
\text { MPH }\end{array}$ & $\begin{array}{r}\text { HSGE } \\
\text { MPH }\end{array}$ & $\begin{array}{r}\text { WSG4 } \\
\text { MPH }\end{array}$ & $\begin{array}{l}\text { WSG7 } \\
\text { MPH }\end{array}$ & $\begin{array}{c}\text { WSGP } \\
\text { MPH }\end{array}$ \\
\hline 0.3 & 31.3 & 30.9 & 28. 8 & 30.3 & 29. 1 & 30.6 & 28.9 & 27.6 & 23. 7 \\
\hline 日. 7 & 30.4 & 29.9 & 27. 0 & 28. 2 & 27.5 & 28.8 & 26.9 & 26.0 & 22.6 \\
\hline 2日. 2 & 28.6 & 27.5 & 24. 9 & 26.2 & 25.8 & 26.5 & 25. 3 & 24. 8 & 21.4 \\
\hline 25.9 & 27.5 & 26.2 & 23.9 & 25. 2 & 24. 5 & 25.4 & 24. 3 & 23. 5 & 20.0 \\
\hline 26. 4 & 27.3 & 26.5 & 24.0 & 25.4 & 24.7 & 25.7 & 24. 4 & 23. 5 & 20.3 \\
\hline 26. 1 & 27.6 & 26.7 & 24.2 & 25.6 & 24.8 & 25.7 & 24. 6 & 24.1 & 20.9 \\
\hline 24. 9 & 26. 1 & 25.8 & 23. 3 & 24. 2 & 23. 4 & 24.9 & 23. 3 & 22. 8 & 19.7 \\
\hline 24. 4 & 26.0 & 25.2 & 23. 2 & 24. 2 & 23. 2 & 24.5 & 23. 2 & 22. 5 & 19.3 \\
\hline 25. 2 & 26.5 & 25.4 & 23. 2 & 23. 9 & 22.4 & 24.8 & 22.9 & 21.3 & 17. 8 \\
\hline 24. 3 & 25.8 & 24.6 & 22. 3 & 22. 8 & 21. 3 & 24.0 & 22. 0 & 20.1 & 16.9 \\
\hline 21.6 & 22.6 & 21.6 & 19. 5 & 19. 8 & 18. 4 & 21.2 & 19. 2 & 17.2 & 14. 2 \\
\hline 20. 3 & 21. 3 & 20. 1 & 18. 2 & 18. 3 & 17.0 & 20.0 & 18. 0 & 16. 0 & 13. 3 \\
\hline 20. 0 & 20.8 & 19.8 & 18. 1 & 18. 1 & 17.4 & 19.7 & 18. 1 & 16. 2 & 13. 5 \\
\hline 20.7 & 21.6 & 20.4 & 18. 7 & 19.0 & 18. 1 & 20.3 & 18. 4 & 16. 4 & 13. 7 \\
\hline 23. 0 & 24. 0 & 221 & 20. 2 & 20.5 & 19. 5 & 22.0 & 19. 5 & 17.3 & 14. 4 \\
\hline 23. 3 & 23. 9 & 22. 3 & 20.6 & 21.3 & 20.3 & 22. 0 & 19. 8 & 17. $\mathrm{B}$ & 14.9 \\
\hline 23. 7 & 24.7 & 23. 4 & 21.3 & 21.5 & 20. 4 & 228 & 20.6 & 18. 7 & 15.6 \\
\hline 25.7 & 27.1 & 258 & 24.0 & 24.6 & 23. 3 & 25.6 & 23. 8 & 21.7 & 18. 0 \\
\hline 28. 2 & 29.8 & 28. 5 & 26. 7 & 27.0 & 26.3 & 28.6 & 26.4 & 23.9 & 19.7 \\
\hline 33. 2 & 35.1 & 33.7 & 31.9 & 32. 3 & 31.4 & 34.0 & 31.8 & 28.7 & 23. 5 \\
\hline 33.8 & 35.5 & 34.6 & 33. 4 & 35. 0 & 33. 3 & 35. 1 & 33. 8 & 31.6 & 25. 7 \\
\hline 33.6 & 34.9 & 33. 5 & 31.6 & 33. 3 & 32. 2 & 33. 5 & 31.9 & 30.4 & 25. 5 \\
\hline 32.2 & 33. 8 & 31.9 & 30. 0 & 31.5 & 30.3 & 31.5 & 30.2 & 28. 4 & 23. 8 \\
\hline 31.9 & 33.6 & 32. 0 & 30. 2 & 32.0 & 31.0 & 31.8 & 30.4 & 28. 8 & 24.4 \\
\hline$=6$. & 27.8 & 26.7 & 24.6 & 25. 5 & 24.5 & 26. 3 & 24.6 & 23.0 & 19.4 \\
\hline
\end{tabular}

94

\begin{tabular}{cc}
94 & 94 \\
& \\
NAME & SITE LOCATION: \\
\hline WD13 & SITE S-13 70-ft \\
WSF? & TURBINE Fב \\
WSFG & TURBINE FG \\
WSFO & TURBINE F10 \\
WSF3 & TURBINE F14 \\
WSG4 & TURBINE G4 \\
WSG9 & TURBINE G9
\end{tabular}




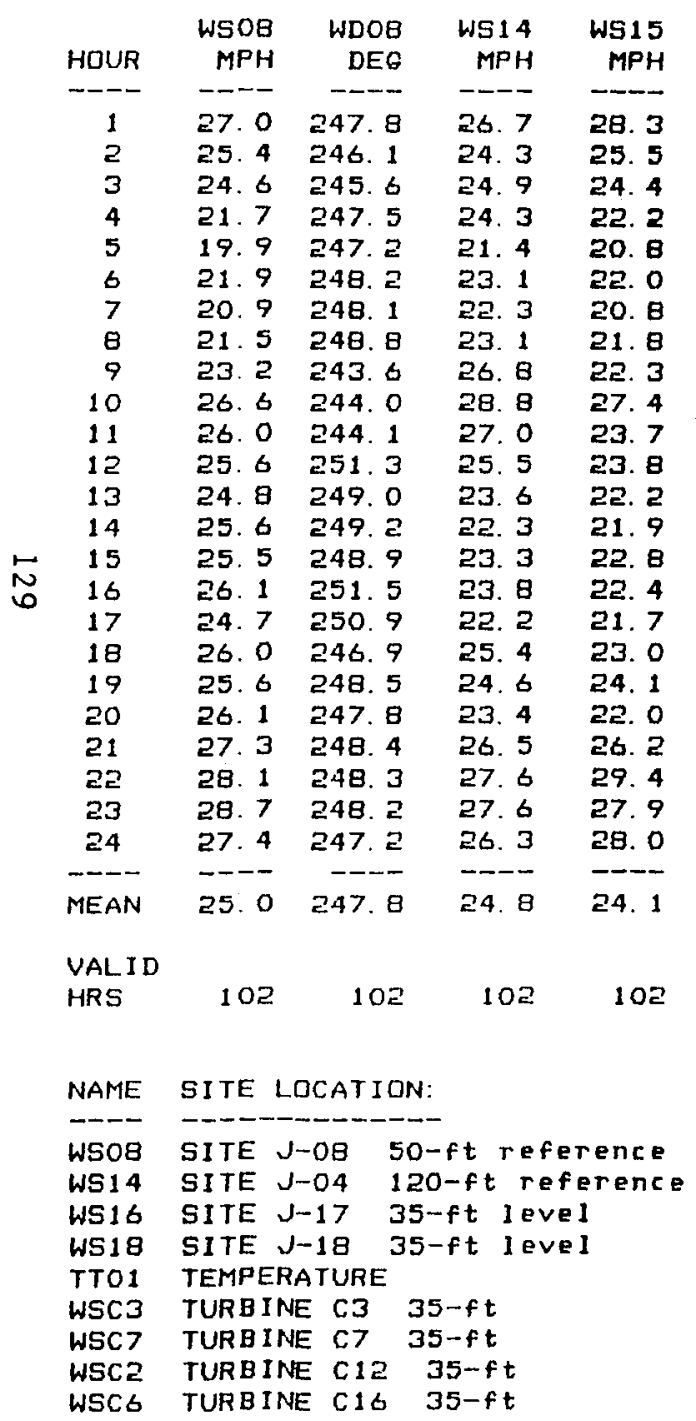

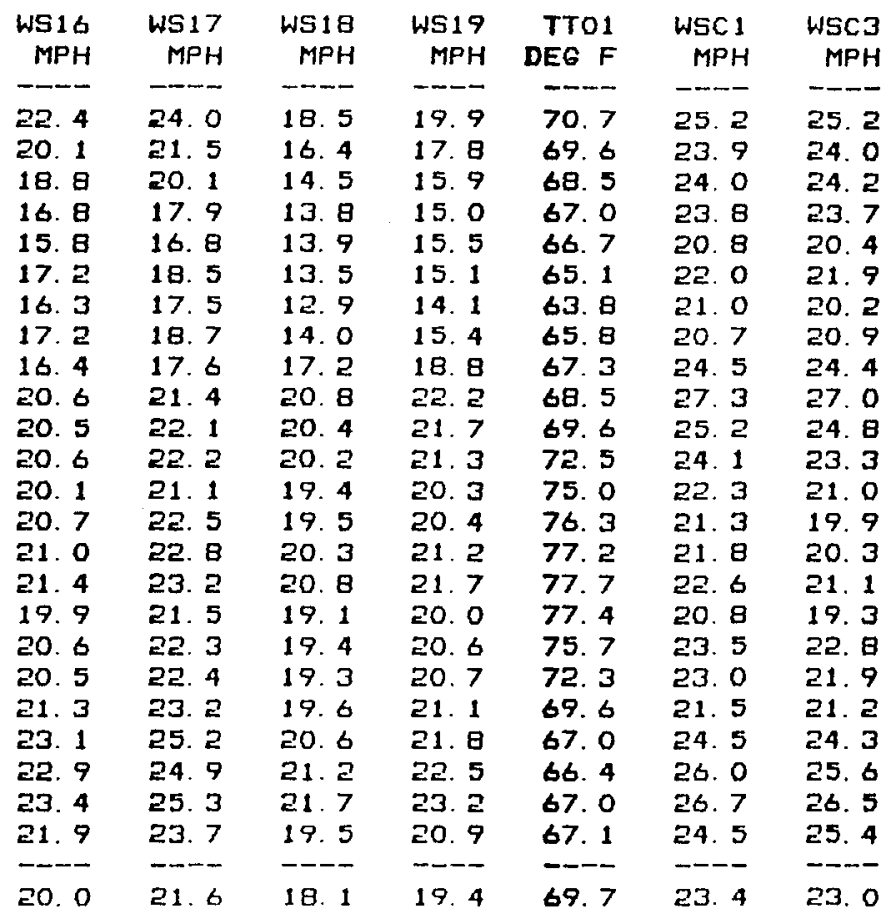

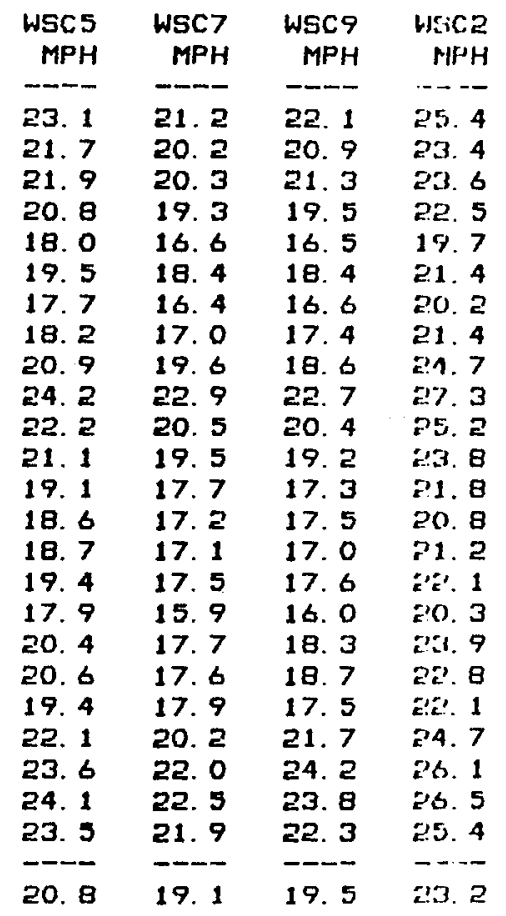

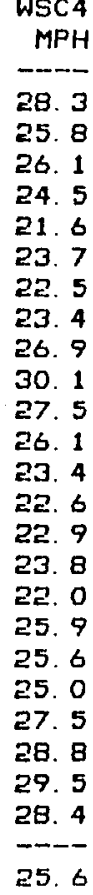

WSC6 MPH

西 21.5

21.

4. 517.7

17.3

19. 2

18. 1

1日. 9

21. 8

25. 0

20. 8

18. 7

18. 0

18. 0

18. 4

17. 0

18. 8

14. 4

13. 3

24.

24.9

23. 6

25.6 20.6

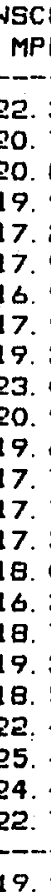

102

$102 \quad 102$

$102 \quad 140$

102

102

NAME SITE LQCATION:

WDOQ SITE J-OB DIRECTION

WS15 SITE J-19 40-ft level

WS17 SITE J-17 70-ft toweT

WS19 SITE J-18 70-ft tower

WSC 1 TURBINE CI 35-ft

WSCS TURBINE C5 35-ft

WSC9 TURBINE C9 35-ft

WSCA TURBINE C14 $35-f t$

WSCB TURBINE C1B $35-f t$ 
DIURNAL SUMMARY BY PARAMETER

DOE FREE FLOW DATA - JESS RANCH

OCTOBER 1-3 plus 7-10, 1987

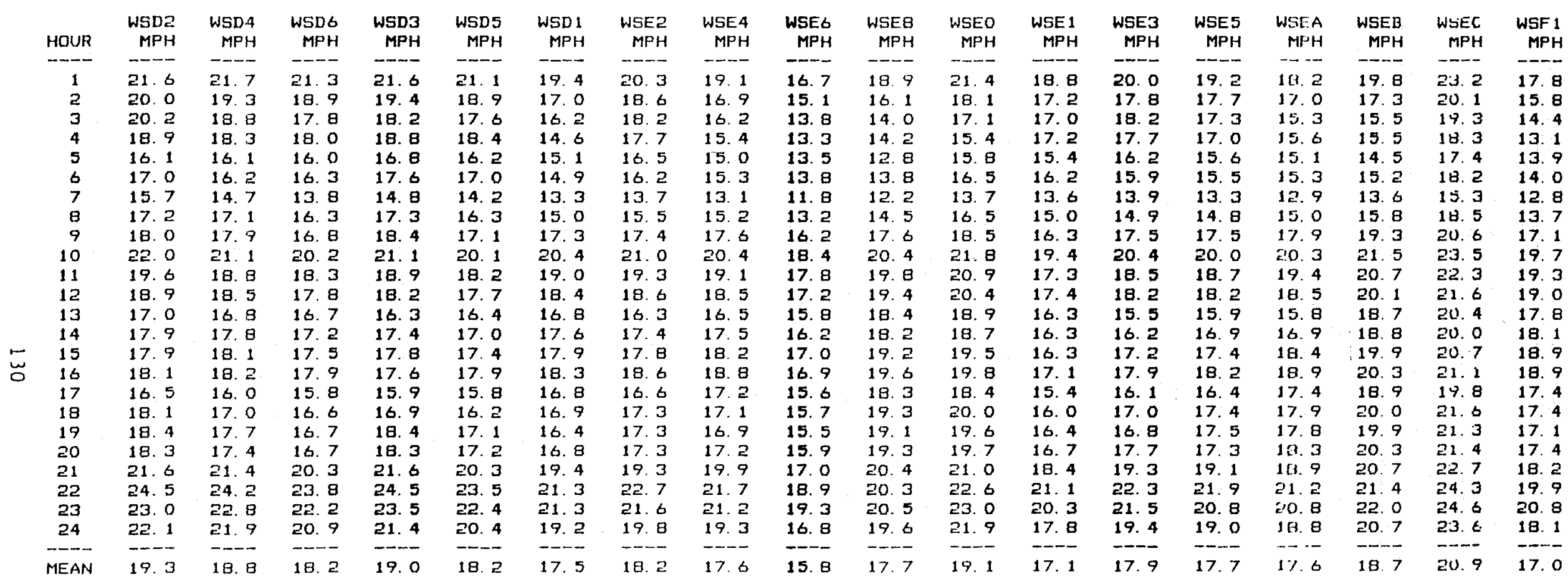

$\begin{array}{llllll}\text { VALID } & & & & & \\ \text { HRS } & 102 & 102 & 102 & 102 & 102\end{array}$

102

102

102

102

NAME SITE LOCATION:

WSD2 TURBINE D2 35-ft

WSDG TURBINE DS $35-f t$

WSDS TURBINE D15 35-ft

WSE? TURBINE E2 35-ft

WSE 6 TURBINE EG $35-f t$

WSEO TURBINE E1O $35-f t$

WSE3 TURBINE E13 $35-f t$

WSEA TURDINE EIB $35-f t$

WSEC TURBINE EaZ $35-f t$

$\begin{array}{llc}\text { WSD4 } & \text { TURBINE D4 } & 35-\mathrm{ft} \\ \text { WSD3 } & \text { TURBINE D13 } & 35-\mathrm{ft} \\ \text { WSD1 } & \text { TURBINE D21 } & 35-\mathrm{ft} \\ \text { WSE4 } & \text { TURBINE E4 } & 35-\mathrm{ft} \\ \text { WSEB } & \text { TURBINE EB } & 35-\mathrm{ft} \\ \text { WSE1 } & \text { TURBINE E11 } & 35-\mathrm{ft} \\ \text { WSE5 } & \text { TURBINE E15 } & 35-\mathrm{ft} \\ \text { WSEB } & \text { TURBINE E2O } & 35-\mathrm{ft} \\ \text { WSF1 } & \text { TURBINE F1 } & 35-\mathrm{ft}\end{array}$


DOE FREE FLOW DATA - JESS RANCH

OCTOBER 1-3 plUS 7-10, 1987

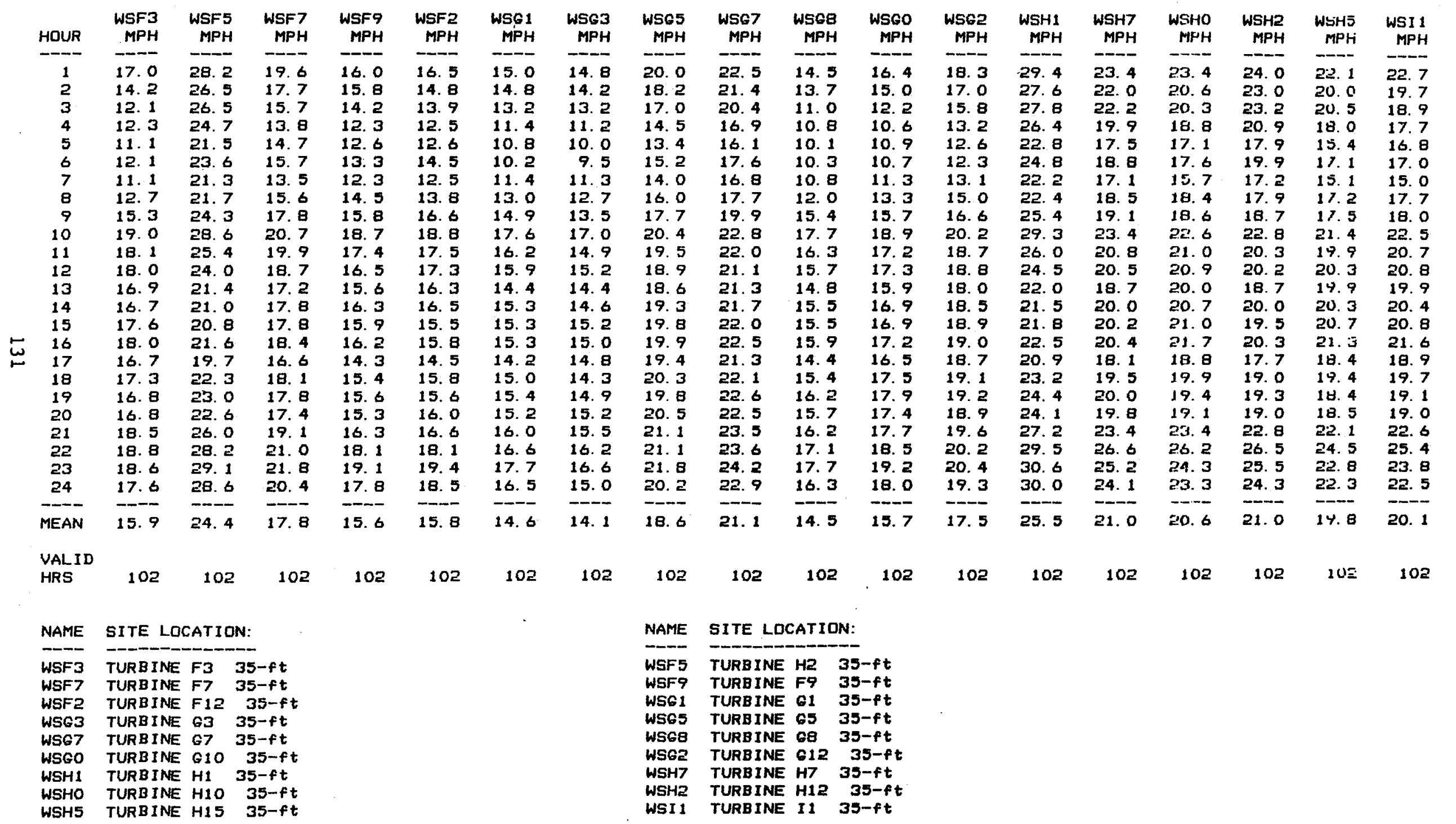




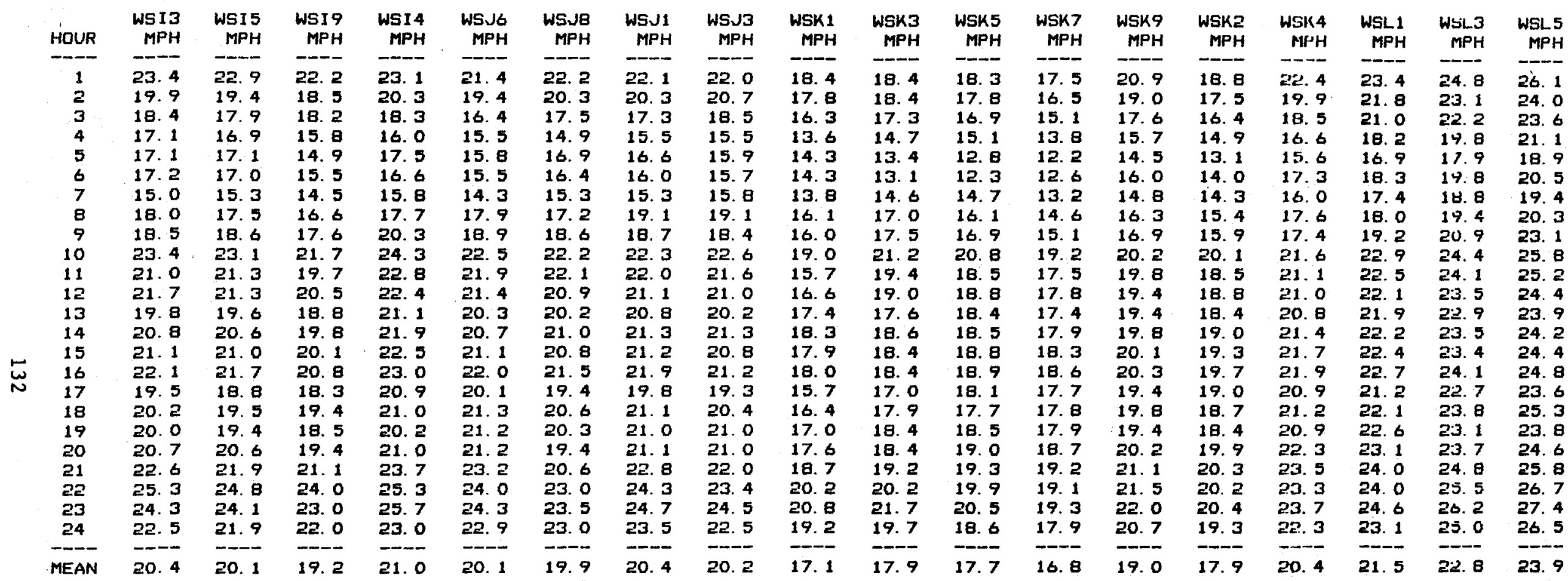

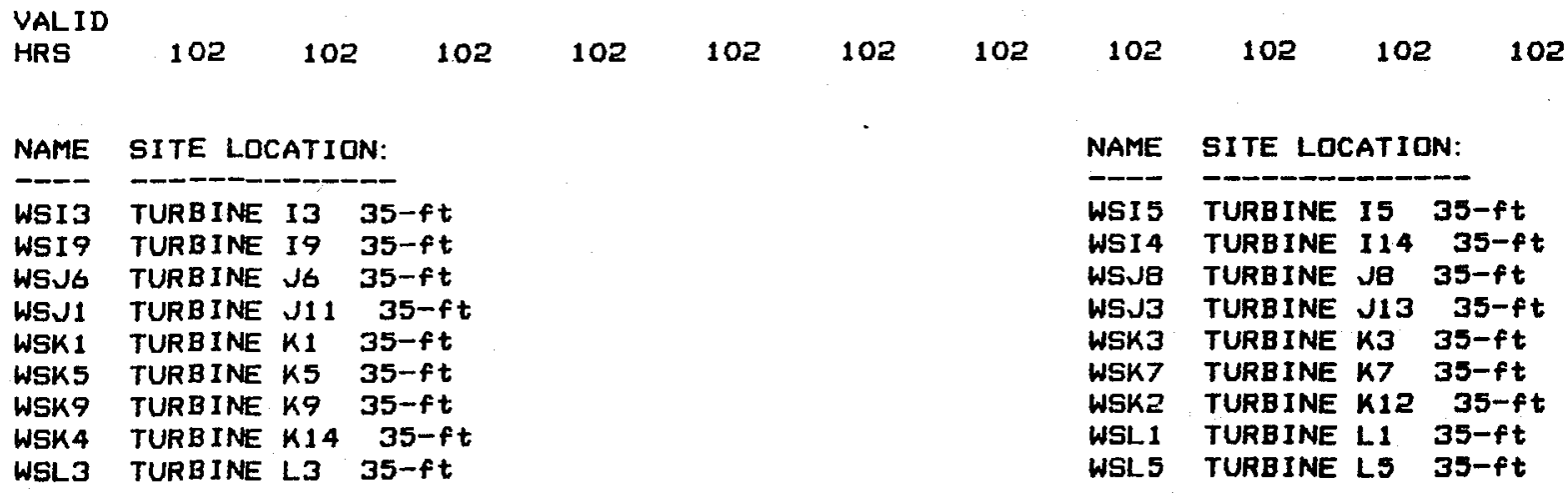




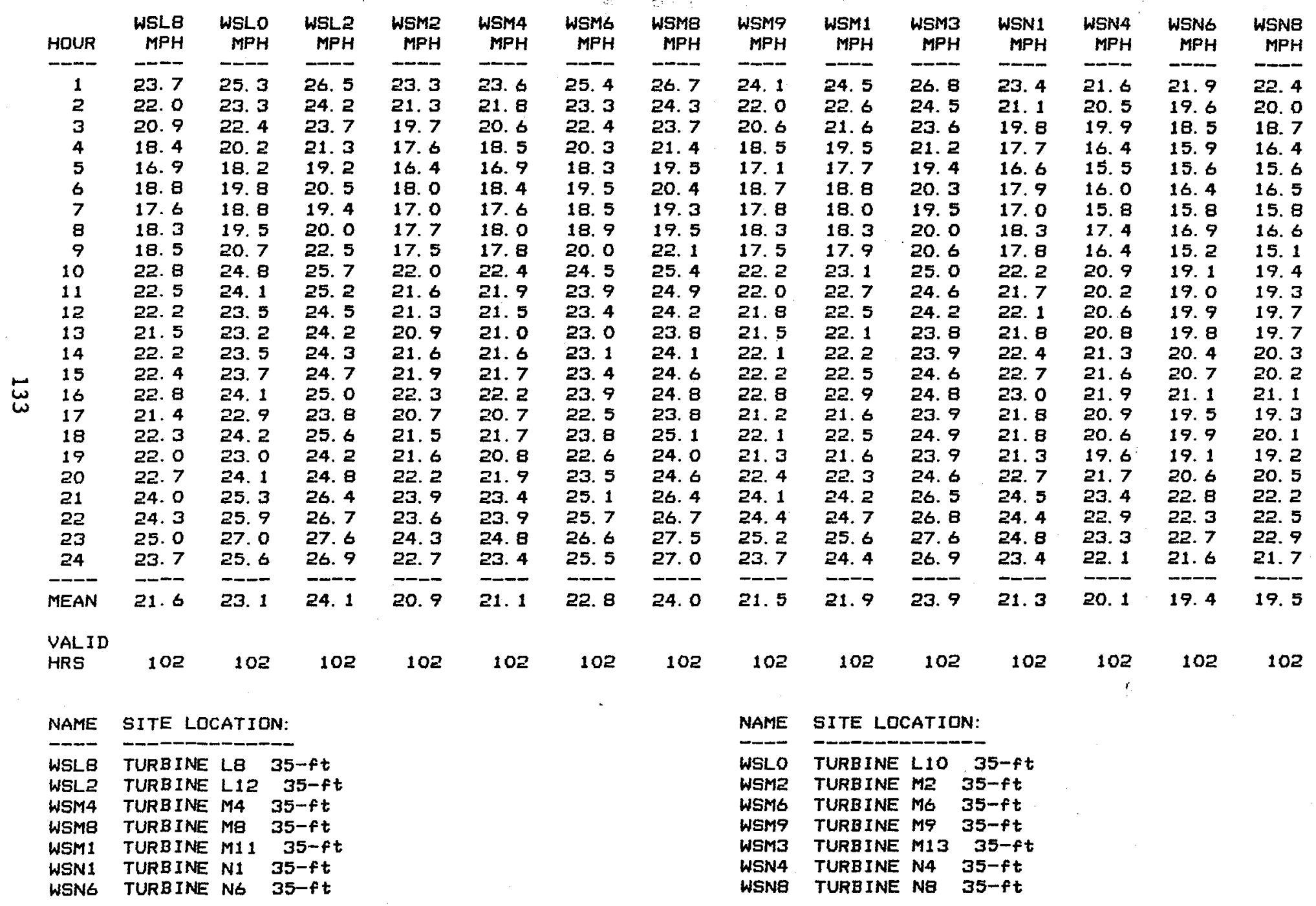




\begin{tabular}{|c|c|c|}
\hline $\begin{array}{l}\text { Document Control } \\
\text { Page }\end{array}$ & $\begin{array}{l}\text { 1. SERI Report No. } \\
\text { SERI/STR-217-3404 }\end{array}$ & 3. Recipient's Accession No. \\
\hline \multirow{2}{*}{\multicolumn{2}{|c|}{$\begin{array}{l}\text { 4. Title and Subtitle } \\
\text { Free-Flow Variability on the Jess and Souza Ranches, } \\
\text { Altamont Pass }\end{array}$}} & $\begin{array}{l}\text { 5. Publication Date } \\
\text { March } 1989\end{array}$ \\
\hline & & 6. \\
\hline \multicolumn{2}{|c|}{$\begin{array}{l}\text { 7. Author(s) } \\
\text { R. Nierenberg }\end{array}$} & 8. Performing Organization Rept. No. \\
\hline \multirow{2}{*}{\multicolumn{2}{|c|}{$\begin{array}{l}\text { 9. Performing Organization Name and Address } \\
\text { Altamont Energy Corporation } \\
68 \text { Mitche11 Blvd., } 205 \\
\text { San Rafael, CA } 94903\end{array}$}} & $\begin{array}{l}\text { 10. Project/Task/Work Unit No. } \\
\text { WE911101 }\end{array}$ \\
\hline & & $\begin{array}{l}\text { 11. Contract (C) or Grant (G) No. } \\
\text { (C) DE-FCO23-85CH10253 } \\
\text { (G) }\end{array}$ \\
\hline \multicolumn{2}{|c|}{ 12. Sponsoring Organization Name and Address } & 13. Type of Report \& Period Covered \\
\hline \multirow{2}{*}{\multicolumn{2}{|c|}{$\begin{array}{l}\text { Solar Energy Research Institute } \\
\text { A Division of Midwest Research Institute } \\
1617 \text { Cole Blvd. } \\
\text { Golden, C0 } 80402-3393\end{array}$}} & Technica1 Report \\
\hline & & 14. \\
\hline \multicolumn{3}{|c|}{$\begin{array}{l}\text { 15. Supplementary Notes } \\
\text { Technical Monitor: W. Bollmeier }\end{array}$} \\
\hline \multicolumn{3}{|c|}{$\begin{array}{l}\text { 16. Abstract (Limit: } 200 \text { words) This report is one of a series of such documents that pre- } \\
\text { sent the findings of field tests conducted under the Department of Energy's (DOE) } \\
\text { Cooperative Field Test Program with the U.S. wind industry. The report provides the } \\
\text { results of a study to collect data at two windfarms. The two wind turbine arrays, } \\
\text { located in the Altamont Pass east of San Francisco, were instrumented with anemom- } \\
\text { eters and a central monitoring computer. To. obtain a high spatial density of wind- } \\
\text { speed measurements, every other turbine in both arrays was instrumented. Wind-speed } \\
\text { data were collected over a period of four days during the summer high-wind season } \\
\text { with all turbines shut down. The resultant data set was analyzed to determine the } \\
\text { spatial variability of the wind resource in the two arrays. Because no turbine } \\
\text { wakes were present, variation in the flow was caused by the interaction of the flow } \\
\text { with the terrain and was not a function of turbine wake interaction. The free-flow } \\
\text { data sets can be used by other researchers to refine numerical free-flow computer } \\
\text { models. The data sets will be used to fine tune and validate these computer models. } \\
\text { In addition, the free-flow data will be compared to results of a wake energy deficit } \\
\text { study also under way on these turbine arrays. }\end{array}$} \\
\hline
\end{tabular}

17. Document Analysis

a. Descriptors wind energy ; wind turbine ; windfarm ; wind turbine array

b. Identifiers/Open-Ended Terms

c. UC Categories 261

18. Availability Statement

National Technical Information Service

U.S. Department of Commerce

5285 Port Royal Road

Springfield, VA 22161
19. No. of Pages

143

20. Price

$\mathrm{A} 07$ 